\title{
ipen
}

INSTITUTO DE PESQUISAS ENERGÉTICAS E NUCLEARES

Autarquia associada à Universidade de São Paulo

\section{LEVANTAMENTO DOS NÍVEIS DE RADIOATIVIDADE NATURAL EM ÁGUAS DO ALTO VALE DO RIBEIRA À PLANÍCIE COSTEIRA DO LITORAL SUL DO ESTADO DE SÃO PAULO}

SUELI CARVALHO DE JESUS

Dissertação apresentada como parte dos requisitos para obtenção do Grau de Mestre em Ciências na Área de Tecnologia Nuclear - Aplicações.

Orientadora:

Prof ${ }^{\mathrm{a}}$. Dr ${ }^{\mathrm{a}}$. Joselene de Oliveira 
Dedico este trabalho a minha família, pela compreensão, amor, carinho e dedicação.

Por aceitar minhas escolhas e me apoiar sempre. 


\section{AGRADECIMENTOS}

Principalmente a Deus, pois sem ele não existiria e não alcançaria essa benção.

À minha orientadora Dra. Joselene de Oliveira, pela excelente condição de trabalho, orientação, amizade e principalmente, por todos os conhecimentos transmitidos.

Ao IPEN por fornecer toda infra-estrutura de suas instalações acadêmicas e laboratoriais que possibilitaram o desenvolvimento desta pesquisa.

À Comissão Nacional de Energia Nuclear - CNEN, pela concessão de bolsa de formação de pesquisador ao nível de Mestrado - Processo Nº1341-001015/2009-33.

À GPG/IPEN - Gerência de Ensino, pelo financiamento em participação de Eventos Científicos Nacionais e pelo auxílio financeiro de parte das atividades de campo.

À Prof ${ }^{a}$ Dra. Elisabete de Santis Braga, do Laboratório de Nutrientes, Micronutrientes e Traços no Oceano - LABNUT do Instituto Oceanográfico da Universidade de São Paulo, pela sua amizade, sua imensa contribuição na obtenção dos resultados das concentrações de nutrientes e nos trabalhos de campo.

Ao Conselho Nacional de Pesquisa e Desenvolvimento Científico e Tecnológico, Processo CNPq n ${ }^{\circ}$ 552437/2007-7, “Impactos biogeoquímicos e sócio-econômicos na região do complexo estuarino-lagunar de Cananéia/Iguape - com ênfase à influência do Valo Grande" que financiou o projeto coordenado pela Dra. Elisabete de Santis Braga do LABNUT.

Ao Conselho Nacional de Pesquisa e Desenvolvimento Científico e Tecnológico, Processo CNPq $\mathrm{n}^{\mathrm{o}}$ 573.601./2008-9, Institutos Nacionais de Ciências e Tecnologia - INCT, "Transferência de Materiais na Interface Continente-Oceano", que financiou o projeto coordenado pelo Prof. Dr. Luiz Drude de Lacerda do LABOMAR (Laboratório de Ciências do Mar), da Universidade Federal do Ceará. 
Ao Laboratório de Radiometria Ambiental da Gerência de Metrologia das Radiações, pela infra-estrutura fornecida que permitiu as realizações das análises radioquímicas e radiométricas no desenvolvimento deste trabalho.

Ao Bel. Victor Gonzalez Chiozzini do LABNUT, pela colaboração na obtenção dos dados hidrológicos e hidroquímicos no complexo estuarino-lagunar de Cananéia/ Iguape, no escopo deste trabalho.

Ao MSc. João Carlos Maluf, pela elaboração dos mapas das localizações dos pontos de coleta.

Aos alunos do LABNUT pela amizade, apoio e companheirismo durante as coletas de água em trabalho de campo.

À tripulação da embarcação Albacora e funcionários da Base de Pesquisa "Dr. João de Paiva Carvalho" em Cananéia, do Instituto Oceanográfico da Universidade de São Paulo, que ajudaram diretamente ou indiretamente no desenvolvimento deste trabalho de pesquisa.

Aos meus pais, Manuel da Conceição e Wilma Carvalho pelo imenso carinho, apoio e compreensão nos momentos de ausência, e pelo grande incentivo que foram fundamentais por mais essa conquista.

Ao meu irmão Williams e minhas irmãs, Sandra, Solange e Shirlei pelo estímulo e apoio em todos os momentos desta caminhada.

Ao meu noivo, Hugo pela paciência e compreensão devido à distância, e por todos os seus incentivos ao longo desta trajetória.

A Fernanda Abrahão e Glorivânia, pela sua amizade e ajuda na preparação e coletas das minhas amostras.

Aos meus colegas da sala de bolsistas do Laboratório de Radiometria Ambiental, Lúcia, 
Ademar, Simone, Luciana e Reginaldo, pela amizade, apoio e companheirismo durante esse tempo de convívio.

Ao Dr. Hugo Chirinos Collantes, pelo incentivo e apoio na conclusão deste trabalho. 


\title{
LEVANTAMENTO DOS NÍVEIS DE RADIOATIVIDADE NATURAL EM ÁGUAS dO ALTO VALE DO RIBEIRA À PLANÍCIE COSTEIRA DO LITORAL SUL DO ESTADO DE SÃO PAULO
}

\author{
Sueli Carvalho de Jesus
}

\begin{abstract}
RESUMO
As trocas complexas de água salgada, água subterrânea e água de superfície que ocorrem na região costeira afetam diretamente os ciclos biogeoquímicos globais e a aplicação de traçadores isotópicos, dentre eles radionuclídeos naturais das séries radioativas do $\mathrm{U}$ e do Th, se apresenta como uma ferramenta poderosa para se rastrear fontes e sumidouros de elementos-traço e nutrientes nestes ecossistemas. O comportamento único do Ra utilizado para estimar a contribuição destes fluxos é observado no estuário subterrâneo, uma zona de mistura entre a água doce subterrânea e a água salgada nos aqüíferos costeiros. Nas séries naturais de decaimento radioativo do $\mathrm{U}$ e do Th há quatro isótopos naturais de $\mathrm{Ra}:{ }^{223} \mathrm{Ra}$ $\left(\mathrm{t}_{1 / 2}=11,4 \mathrm{~d}\right),{ }^{224} \mathrm{Ra}\left(\mathrm{t}_{1 / 2}=3,7 \mathrm{~d}\right),{ }^{228} \mathrm{Ra}\left(\mathrm{t}_{1 / 2}=5,7 \mathrm{a}\right) \mathrm{e}{ }^{226} \mathrm{Ra}\left(\mathrm{t}_{1 / 2}=1.600 \mathrm{a}\right)$. As meias-vidas destes isótopos correspondem bem com a duração de muitos processos costeiros. Todos estes isótopos derivam do decaimento de um isótopo de Th precursor, que está fortemente ligado ao material particulado. Devido ao Ra ser mobilizado no ambiente marinho, os sedimentos constituem uma fonte contínua dos isótopos de Ra para as águas estuarinas em taxas estabelecidas por suas constantes de decaimento. As atividades dos isótopos de Th nos sedimentos e o coeficiente de distribuição do Ra entre os sedimentos e a água, determinam a entrada potencial de cada isótopo de Ra para um dado ambiente aquático. Como o ${ }^{228} \mathrm{Ra}$ é regenerado mais rapidamente do que o ${ }^{226} \mathrm{Ra}$, estuários com altas taxas de atividade ${ }^{228} \mathrm{Ra} /{ }^{226} \mathrm{Ra}$ na água devem ter um alto grau de troca com os sedimentos na região costeira ou com a água subterrânea drenando próximo a ela. Esta informação é útil para elucidar a contribuição de sistemas estuarinos para a troca de elementos-traço, N, P e C na zona de mistura. As funções fonte combinadas para o Ra na área costeira incluem a sua entrada a partir dos rios nas formas dissolvida e particulada, das suas concentrações dissolvidas no oceano, da dessorção dos sedimentos costeiros e da água subterrânea. A importância relativa de cada uma destas fontes é geralmente uma função da hidrogeologia específica de cada local e do ambiente no qual as amostras foram coletadas em relação ao
\end{abstract}


gradiente de salinidade (extensão da mistura de água doce/ água salgada). Desta forma, os isótopos de Ra fornecem informações fundamentais a respeito da interação dos sedimentos, água subterrânea e águas estuarinas. Neste projeto, a distribuição de isótopos naturais de $\mathrm{Ra}$ foi estudada em amostras de águas de superfície, subterrâneas e estuarinas coletadas nas estações seca e chuvosa (2009 - 2010) na região do Vale do Ribeira, litoral sul do Estado de São Paulo. O inventário permitiu utilizá-los como traçadores de descargas fluvial e subterrânea para o complexo estuarino-lagunar de Cananéia/Iguape. As trocas complexas da água subterrânea/água de superfície na bacia do Rio Ribeira de Iguape, assim como os fluxos de vários constituintes para o complexo estuarino-lagunar de Cananéia/Iguape ainda são ainda componentes pouco conhecidos nos balanços hídrico e de materiais no cenário de interesse. Os resultados obtidos mostraram que há uma predominância do isótopo de ${ }^{228} \mathrm{Ra}$ em todas as amostras analisadas, embora as concentrações detectadas tanto no Alto Vale do Ribeira como ao longo da Planície Costeira indiquem que estes resultados representam níveis naturais de fundo, denotando pequena ou mínima intervenção humana. Nas amostras coletadas ao longo do Rio Ribeira de Iguape e nos estuários de Cananéia e de Iguape, as maiores concentrações dos isótopos de Ra foram observadas nas águas de fundo, indicando a difusão do ${ }^{228} \mathrm{Ra}$ dos sedimentos recentemente depositados como uma fonte potencial das concentrações aumentadas deste isótopo em relação aos demais. As concentrações dos isótopos de meias-vidas curtas foram negligenciáveis, em sua maior parte menores que o limite inferior de detecção do método. Os fluxos de Ra para o sistema na Barra de Cananéia é fortemente influenciado pelas correntes e canais de maré, que modulam o aumento ou diminuição das concentrações de $\mathrm{Ra}$ em resposta direta ao respectivo aumento e diminuição da salinidade das águas. No estuário de Iguape e nas estações hidroquímicas realizadas no Rio Ribeira do Iguape observou-se uma correlação linear entre a quantidade de material em suspensão (MES) e o aumento da concentração de ${ }^{228} \mathrm{Ra}$. Quando se avaliam qualitativamente as diferenças entre o comportamento dos dois isótopos de $\mathrm{Ra}$ de meias-vidas longas, as concentrações de ${ }^{226} \mathrm{Ra}$ não apresentaram distribuição idêntica aquelas do ${ }^{228} \mathrm{Ra}$. Isto demonstra um aporte negligenciável advectivo das águas intersticiais dos sedimentos e subterrâneas para o cenário de interesse. Os fluxos dominantes de elementos-traço, radionuclídeos e nutrientes tem suas maiores fontes centradas no compartimento fluvial, sedimentos e material em suspensão. 


\title{
ASSESSMENT OF NATURAL RADIOCTIVITY LEVELS IN WATERS \\ FROM HIGHER RIBEIRA VALLEY UNTIL THE SOUTHERN \\ SÃo PAUlo STATE COASTAL PLAIN
}

\section{Sueli Carvalho de Jesus}

\begin{abstract}
The complex exchange of fluvial, subsurface and seawater within a coastal area directly affects global biogeochemical cycles and the application of isotopic tracers, mainly natural radionuclides from $U$ and Th series, is a powerful tool to track sources and sinks of trace elements and nutrients to this systems. The unique Ra signature applied to quantify the contribution of such fluxes is acquired within the subterranean estuary, a mixing zone between fresh groundwater and seawater in coastal aquifers. In the $U$ and Th natural radioactive decay series there are four radium isotopes: ${ }^{223} \mathrm{Ra}\left(\mathrm{t}_{1 / 2}=11.4 \mathrm{~d}\right),{ }^{224} \mathrm{Ra}\left(\mathrm{t}_{1 / 2}=\right.$ $3.7 \mathrm{~d}),{ }^{228} \mathrm{Ra}\left(\mathrm{t}_{1 / 2}=5.7 \mathrm{y}\right)$ and ${ }^{226} \mathrm{Ra}\left(\mathrm{t}_{1 / 2}=1,600 \mathrm{y}\right)$. Their wide range in half-lives corresponds well with the duration of many coastal processes. All these Ra isotopes derive from decay of Th parents, which are tightly bound to particles. Because Ra is mobilized in the marine environment, sediments provide a continuous source of $\mathrm{Ra}$ isotopes to estuarine waters at rates set by its decay constants. The Th isotope activities in the sediments and the distribution coefficient of $\mathrm{Ra}$ between the sediments and water determine the potential input of each $\mathrm{Ra}$ isotope to the water. Because ${ }^{228} \mathrm{Ra}$ is regenerated much faster than ${ }^{226} \mathrm{Ra}$, estuaries with high ${ }^{228} \mathrm{Ra} /{ }^{226} \mathrm{Ra}$ activity ratios in the water must have a high degree of exchange with sediments on the sea bed or with groundwater draining nearby. This information is useful to elucidate the contribution of estuarine systems to the exchange of trace elements, N, P and C in the mixing zone. The combined source functions for Ra in a coastal area include riverine particulates/ dissolved input, oceanic dissolved concentrations, input from sediments and groundwater. The relative significance of each of these sources is usually a function of the site-specific hydrogeology and where the samples are taken relative to the salinity gradient (extent of freshwater/saltwater mixing). Thus, the $\mathrm{Ra}$ isotopes provide fundamental information on the interaction of sediments, groundwater and estuarine waters. In this project, the distribution of natural Ra isotopes was studied in
\end{abstract}


surface, groundwater and estuarine water samples collected from dry and wet seasons (2009 - 2010) campaigns performed in Ribeira Valley, Southern São Paulo State. The inventory allowed the application of $\mathrm{Ra}$ isotopes as tracers of fluvial and groundwater discharges to the Cananéia-Iguape estuarine complex. The exchange of groundwater/ surface water in Ribeira do Iguape River basin and related fluxes of several constituents for the Cananéia-Iguape estuarine complex mass balance is still not very well known. The results obtained in this research work evidenced that there is a prevalence of ${ }^{228} \mathrm{Ra}$ isotope in all the set of samples analyzed. However, the activity concentrations of Ra isotopes determined from Higher Ribeira Valley through the Southern Coastal Plain of São Paulo are representative of natural background levels, showing low or minimal human intervention. In the set of samples collected along Ribeira do Iguape River, Cananéia and Iguape outlets, the higher concentrations of Ra were observed in bottom waters, indicating the diffusion of ${ }^{228} \mathrm{Ra}$ from sediments recently deposited as a potential source of the increased concentrations of this isotope when compared with others. The activity concentrations of the short-lived Ra isotopes were negligible, lower than the limit of the detection. Fluxes of Ra for Cananéia outlet are strongly influenced by tidal oscillations, which modulate the increase and decrease of Ra concentrations in response of the respective increase and decrease of waters salinity. In Iguape outlet and in hydrochemical stations performed along Ribeira do Iguape River it was observed a linear relationship between the amount of suspended matter and the increase of ${ }^{228} \mathrm{Ra}$ activity concentration. When we evaluate qualitatively the differences in behavior of both long-lived Ra isotopes, the concentrations of ${ }^{226} \mathrm{Ra}$ have not shown similar distribution to ${ }^{228} \mathrm{Ra}$. This demonstrates negligible contribution from advective porewaters and groundwater to the studied scenario. Dominant fluxes of trace-elements, radionuclides and nutrients have their main sources centered on fluvial, sediments and suspended matter compartiments. 
1.2 Ciclagem de elementos-traço em um estuário subterrâneo: geoquímica dos isótopos naturais de

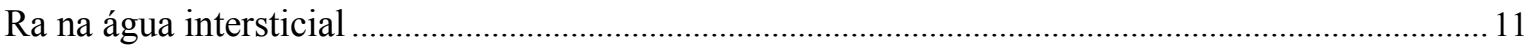

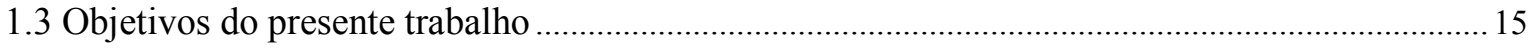

\section{CAPÍTULO 2 - CONTRIBUIÇÃO DA DESCARGA DE ÁGUAS SUBTERRÂNEAS} AO APORTE DE MATERIAS EM REGIÕES COSTEIRAS ..................................18

2.1 Águas subterrâneas

2.2 Origens, definição e importância da descarga de águas subterrâneas como fonte potencial de materiais para regiões costeiras

2.3 Influência de forças marinhas e continentais que contribuem para os fluxos de descarga de águas subterrâneas e materiais na interface continente-oceano.

2.4 Metodologias utilizadas na estimativa da descarga de águas subterrâneas.....

$2.5 \mathrm{O}$ quarteto de isótopos naturais de Ra: elementos-chave para a compreensão dos processos estuarinos

\section{CAPÍTULO 3 - ISÓTOPOS NATURAIS DE Ra COMO TRAÇADORES ISOTÓPICOS DE PROCESSOS NA INTERFACE CONTINENTE-OCEANO .......29}

3.1 O elemento Ra

3.2 Distribuição dos isótopos de Ra no compartimento aquático.

3.2.1 Distribuições de Ra no oceano.

3.2.3 Distribuições de Ra na água superficial.

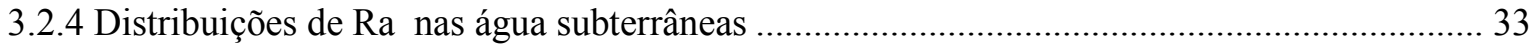

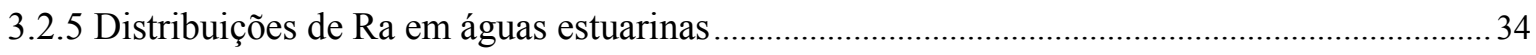

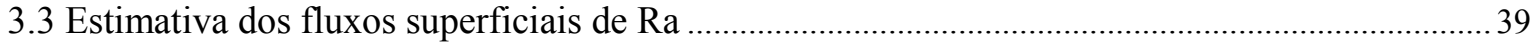

3.4 Aplicações naturais de Ra como traçadores para estimar a descarga de águas subterrâneas em áreas estuarinas 
4.1 Compartimentação do Litoral Sul do Estado de São Paulo

4.2 Características do sistema Estuarino Cananéia- Iguape ............................................................43

4.3 A contribuição das águas do Alto Vale do Ribeira para o cenário estudado............................47

4.4 Padrões de qualidade e uso dos recursos hídricos na região do Vale do Ribeira e litoral Sul do Estado de São Paulo

CAPÍTULO 5 - PARTE EXPERIMENTAL .55

5.1 Obtenção das fibras de acrílico impregnadas com dióxido de manganês para pré-concentração dos isótopos naturais de $\mathrm{Ra}$ de amostras de água

5.2 Coletas das amostras de águas subterrâneas e águas de superfície e águas estuarinas..56

5.3 Determinação das concentrações do ${ }^{223} \mathrm{Ra}$ e ${ }^{224} \mathrm{Ra}$ em amostras de água..... 63

5.4 Determinação das concentrações do ${ }^{226} \mathrm{Ra} \mathrm{e}{ }^{228} \mathrm{Ra}$ em amostras de água .66

5.5 Determinação da eficiência de contagem alfa total para medida de ${ }^{226} \mathrm{Ra}$

5.6 Determinação da eficiência de contagem beta total para medida de ${ }^{226} \mathrm{Ra}$ e de ${ }^{228} \mathrm{Ra}$. .70

5.7 Determinação da eficiência de contagem beta de ${ }^{228} \mathrm{Ra}$ 71

5.8 Determinações dos parâmetros físicos e das concentrações de salinidade e nutrientes dissolvidos nas amostras 72

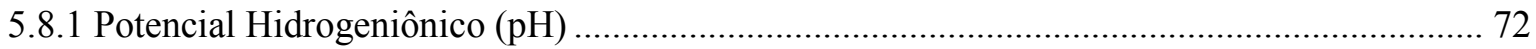

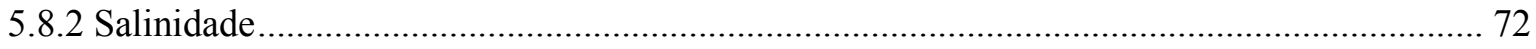

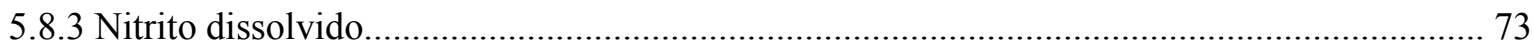

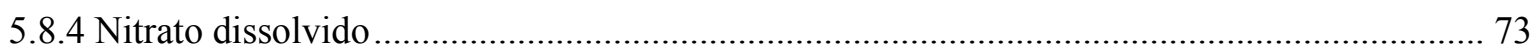

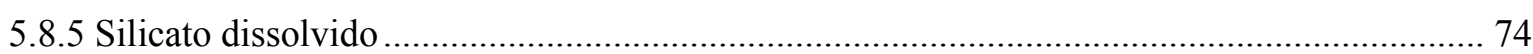

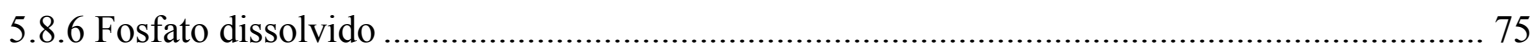

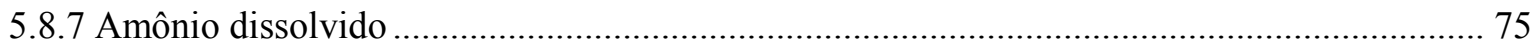

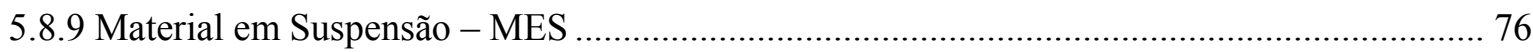

5.8.10 Matéria Orgânica em Suspensão - MO .............................................................. 76

CAPÍTULO 6. RESULTADOS $. . \ldots \ldots \ldots \ldots \ldots \ldots \ldots \ldots \ldots \ldots \ldots \ldots \ldots \ldots \ldots \ldots \ldots \ldots \ldots \ldots \ldots \ldots \ldots \ldots \ldots \ldots \ldots \ldots \ldots \ldots \ldots \ldots \ldots \ldots \ldots . . \ldots 77$

CAPÍTULO 7 - DISCUSSÃO........................................................................................123

CAPÍTULO 8 - CONCLUSÕES .......................................................................... 128

REFERÊNCIAS BIBLIOGRÁFICAS ................................................................... 132 


\section{LISTA DE TABELAS}

Página

TABELA 1 - Corpos d'água da Classe 1 (abrangendo a especial CONAMA). 51

TABELA 2 - Corpos d'água da Classe 2.

TABELA 3 - Eficiências médias aritméticas e respectivos desvio padrão de contagem alfa total para a determinação de ${ }^{226} \mathrm{Ra}$, eficiências beta total para os filhos do ${ }^{226} \mathrm{Ra}$ e beta total para $\mathrm{o}{ }^{228} \mathrm{Ra}$, determinadas no detector proporcional de fluxo gasoso Berthold LB 770. . .77

TABELA 4 - Coordenadas geográficas das amostras das estações hidroquímicas do sistema estuarino Cananéia-Iguape (Fevereiro/ 2009).

TABELA 5- Concentrações de atividade dos isótopos naturais de Ra e nutrientes no sistema estuarino Cananéia-Iguape (Fevereiro/ 2009)......

TABELA 6 - Coordenadas geográficas das amostras das estações hidroquímicas do sistema estuarino Cananéia-Iguape (Agosto/ 2009).

TABELA 7 - Concentrações de atividade dos isótopos naturais de Ra e nutrientes no sistema estuarino Cananéia-Iguape (Agosto/ 2009)

TABELA 8 - Coordenadas geográficas dos poços de águas subterrâneas coletadas em Cananéia, Iguape e Ilha Comprida coletadas (Abril/ 2009). 82

TABELA 9 - Concentração de isótopos naturais de Ra e nutrientes nas águas subterrâneas coletadas em Cananéia e Ilha Comprida (Abril/2009).

TABELA 10 - Coordenadas geográficas dos poços de águas subterrâneas coletados em Cananéia, Iguape e Ilha Comprida (Agosto/ 2010).

TABELA 11 - Concentração de isótopos naturais de Ra e nutrientes nas águas subterrâneas coletadas em Cananéia, Iguape e Ilha Comprida (Agosto/ 2009).

TABELA 12 - Coordenadas geográficas dos poços de águas subterrâneas coletados em Cananéia, Iguape e Ilha Comprida (Abril/ 2010).

TABELA 13 - Concentração de isótopos naturais de Ra e nutrientes nas águas subterrâneas coletadas em Cananéia, Iguape e Ilha Comprida (Abril/ 2010).

TABELA 14 - Coordenadas geográficas dos poços de águas subterrâneas coletadas em Cananéia, Iguape e Ilha Comprida (Maio / 2010).

TABELA 15 - Concentração de isótopos naturais de Ra e nutrientes nas águas subterrâneas coletadas em Cananéia, Iguape e Ilha Comprida (Maio/ 2010).

TABELA 16 - Coordenadas geográficas das amostras de água de superfície do Rio Ribeira de Iguape (Fevereiro/ 2009).

TABELA 17 - Concentração de isótopos naturais de Ra e nutrientes na água de superfície do Rio 
Ribeira de Iguape (Fevereiro/ 2009). 90

TABELA 18 - Coordenadas geográficas das amostras de água de superfície do Rio Ribeira de Iguape (Agosto/ 2009).

TABELA 19 - Concentração de isótopos naturais de Ra na águas de superfícies do Rio Ribeira de Iguape (Agosto/ 2009).

TABELA 20 - Localização geográfica das amostras de água coletadas no Alto Vale do Ribeira, Iporanga, em Abril de 2009.

TABELA 21 - Concentrações de atividade dos isótopos naturais de Ra nas amostras coletadas no Alto Vale do Ribeira, Iporanga, Abril de 2009. 92

TABELA 22 - Localização geográfica das amostras de água coletadas no Alto Vale do Ribeira, Núcleo Caboclos, Setembro de 2009 93

TABELA 23 - Concentrações de atividade dos isótopos naturais de Ra nas amostras coletadas no Alto Vale do Ribeira, Núcleo Caboclos, Setembro de 2009. 94

TABELA 24 - Localização geográfica das amostras de água coletadas no Alto Vale do Ribeira, Núcleo Areado, Outubro de 2009, Outubrol de 2009.

TABELA 25 - Concentrações de atividade dos isótopos naturais de Ra nas amostras coletadas no Alto Vale do Ribeira, Núcleo Areado, Outubro de 2009. 95

TABELA 26 - Localização geográfica das amostras de água coletadas no no Alto do Ribeira, Núcleo Bulhas D’Águas, Outubro de 2009. 96

TABELA 27 - Concentrações de atividade dos isótopos naturais de Ra nas amostras coletadas no Alto Vale do Ribeira, Núcleo Bulhas D’Águas, Outubro de 2009. 96

TABELA 28 - Concentração de atividade dos isótopos naturais de Ra nas amostras coletadas no Alto Vale do Ribeira, Núcleo Santana, Novembro de 2009.

TABELA 29 - Concentrações de atividade dos isótopos naturais de Ra nas amostras coletadas no Alto Vale do Ribeira, Núcleo Ouro Grosso, Novembro de 2009. 97 


\section{LISTA DE FIGURAS}

Página

FIGURA 1- Esquema de decaimento radioativo das séries do ${ }^{238} \mathrm{U},{ }^{232} \mathrm{Th}$ e ${ }^{235} \mathrm{U}$ com os respectivos isótopos de Ra destacados. 9

FIGURA 2 - Ciclo Hidrológico.

FIGURA 3 - Diagrama ilustrando a troca de fluídos (sem escala) dos processos associados com a recarga e descarga de fontes subterrâneas para a região costeira. As setas indicam o movimento dos fluidos. 25

FIGURA 4 - Distribuição simplificada das fontes de Ra para a água do mar, incluindo sedimentos e descarga de água subterrânea.

FIGURA 5 - Distribuição dos isótopo de Ra no estuário como uma função da salinidade. (a) Isótopos de $\mathrm{Ra}$ em um estuário $\left(\mathrm{Ra}_{\mathrm{e}}\right)$ em de rios $\left(\mathrm{Ra}_{\mathrm{r}}\right)$, do oceano $\left(\mathrm{Ra}_{\mathrm{o}}\right)$, e processos adicionais $\left(\mathrm{Ra}_{\mathrm{ad}}\right)$ como dessorção de partículas e difusão de sedimentos. 39

FIGURA 6 - Localização geográfica da área de estudo. 42

FIGURA 7 - Registro histórico de mudança ocorrida no entorno do extremo nordeste da Ilha Comprida, no final do século XVIII (1776-1800?) e no ano de $2000 .$. 45

FIGURA 8 - Bacia Hidrográfica do Rio Ribeira de Iguape e Litoral Sul ........................................ 49

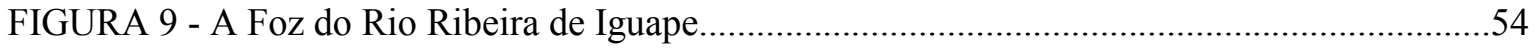

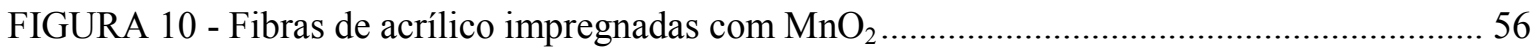

FIGURA 11 - Mapa apresentando as coordenadas geográficas dos pontos de amostragem (estações hidroquímicas), nas região estuarina-lagunar de Cananéia-Iguape.................................................. 57

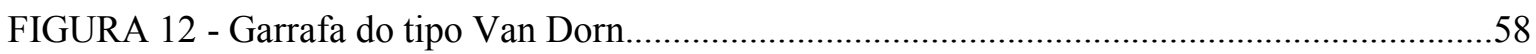

FIGURA 13 - Mapa da localização das estações hidroquímicas no Rio Ribeira de Iguape...............58

FIGURA 14 - Mapa da localização dos pontos de coleta das amostras de águas subterrâneas em Cananéia e Ilha Comprida

FIGURA 15 - Mapa da localização Mapa da localização dos pontos de coleta das amostras de águas subterrâneas em Iguape.

FIGURA 16 - Foto da amostragem de águas subterrâneas no Poço 6, no conjunto Agro Solares (a)

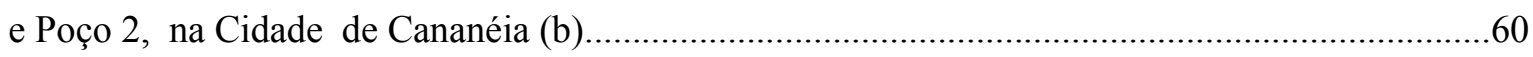

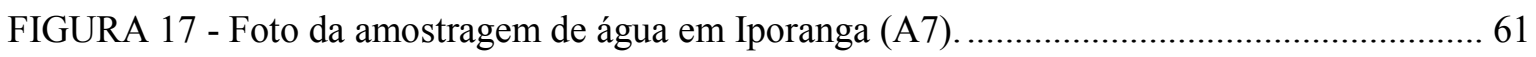

FIGURA 18 - Foto da amostragem de água do Núcleo Bulhas D'água (A24).................................62

FIGURA 19 - Foto da amostragem de água do Núcleo Areado (A21)............................................62

FIGURA 20 - Sistema de percolação para determinação dos isótopos naturais de Ra nas amostras de água ...... 65 
FIGURA 21 - Sistema de coincidência atrasadas, com células de cintilação de 1,1 L utilizado para a determinação de ${ }^{223} \mathrm{Ra} \mathrm{e}^{224} \mathrm{Ra}$ nas amostras de água de superfície e de águas subterrâneas ............ 66 FIGURA 22 - Detector proporcional de fluxo gasoso, modelo Berthold LB 770 ........................... 67

FIGURA 23 - Índice mensal das precipitações ocorridas em 2009 (INMET, 2010) ........................ 98

FIGURA 24 - Acúmulo das chuvas ocorridas no mês de Fevereiro de 2009 (INMET, 2010) ....... 98

FIGURA 25 - Acúmulo das chuvas ocorridas no mês de Agosto de 2009 (INMET, 2010) ............ 99

FIGURA 26 - Distribuição das concentrações de atividade dos isótopos naturais de Ra nas águas subterrâneas de Cananéia, Iguape e Ilha Comprida em Abril/09 e Agosto/09.

FIGURA 27 - Distribuição das concentrações de atividade dos isótopos naturais de Ra nas águas subterrâneas de Cananéia, Iguape e Ilha Comprida em Abril/10 e Maio/10.

FIGURA 28 - Distribuição das concentrações de atividade dos isótopos naturais de Ra nas estações hidroquímicas do sistema estuarino Cananéia-Iguape em Fevereiro/09 e Agosto/09.

FIGURA 29 - Distribuição das concentrações de atividade dos isótopos naturais de Ra no Rio Ribeira de Iguape em Fevereiro/09 e Agosto/09.

FIGURA 30 - Distribuição das concentrações de atividade dos isótopos naturais de Ra no Alto Vale do Ribeira em: Iporanga (a), Núcleo Caboclos (b), Núcleos Areado e Bulhas D’Água (c), Núcleos Ouro Grosso e Santana (d), de Abril/09 a Novembro/09. 102

FIGURA 31 - Distribuição das concentrações de atividade dos isótopos naturais de Ra em função da salinidade observada nas amostras de água subterrânea de Cananéia, Iguape e Ilha Comprida em Abril/09 (a), Agosto/09 (b), Abril/10 (c) e Maio/10 (d) 103

FIGURA 32 - Distribuição das concentrações de atividade dos isótopos naturais de Ra em função da salinidade nas estações hidroquímicas do sistema estuarino Cananéia-Iguape em Fevereiro/09 (a) e Agosto/09 (b) 104

FIGURA 33 - Distribuição das concentrações de atividade dos isótopos naturais de Ra em função da salinidade nas estações hidroquímicas do Rio Ribeira de Iguape em Fevereiro/09 (a) e Agosto/09 (b) 104

FIGURA 34 - Concentrações do material em suspensão (MES) e da matéria orgânica (MO) em suspensão nas estações hidroquímicas no sistema estuarino Cananéia e Iguape em Fevereiro/09 e Agosto/09. 105

FIGURA 35 - Concentrações do material em suspensão (MES) e da matéria orgânica (MO) em suspensão nas amostras do Rio Ribeira de Iguape em Fevereiro/09 e Agosto/09.

FIGURA 36 - Distribuição das concentrações de atividade dos isótopos naturais de Ra em função da concentração do material particulado em suspensão (MES) e da matéria orgânica (MO) em suspensão nas estações hidroquímicas do sistema estuarino Cananéia e Iguape em Fevereiro/09 106 FIGURA 37 - Distribuição das concentrações de atividade dos isótopos naturais de Ra em função da concentração do material particulado em suspensão (MES) e da matéria orgânica (MO) em 
suspensão nas estações hidroquímicas do sistema estuarino Cananéia e Iguape em Agosto/09.... 106 FIGURA 38 - Distribuição das concentrações de atividade dos isótopos naturais de Ra em função da concentração do material particulado em suspensão (MES) e da matéria orgânica (MO) em suspensão nas amostras do Rio Ribeira de Iguape em Fevereiro/09.

FIGURA 39 - Distribuição das concentrações de atividade dos isótopos naturais de Ra em função da concentração do material particulado em suspensão (MES) e da matéria orgânica (MO) em suspensão nas amostras do Rio Ribeira de Iguape em Agosto/09

FIGURA 40 - Distribuição das concentrações de nutrientes nas águas subterrâneas de Cananéia e Ilha Comprida em Abril/09. 108

FIGURA 41 - Distribuição das concentrações de nutrientes nas águas subterrâneas de Cananéia, Iguape e Ilha Comprida em Agosto/09 108

FIGURA 42 - Distribuição das concentrações de nutrientes nas águas subterrâneas de Cananéia, Iguape e Ilha Comprida em Abril/10

FIGURA 43 - Distribuição das concentrações de nutrientes nas águas subterrâneas de Cananéia, Iguape e Ilha Comprida em Maio/10

FIGURA 44 - Distribuição das concentrações de nutrientes nas estações hidroquímicas no sistema estuarino Cananéia e Iguape em Fevereiro/09

FIGURA 45 - Distribuição das concentrações de nutrientes nas estações hidroquímicas no sistema estuarino Cananéia e Iguape em Agosto/09

FIGURA 46 - Distribuição das concentrações de nutrientes nas estações hidroquímicas do Rio Ribeira de Iguape em Fevereiro/09.

FIGURA 47 - Distribuição das concentrações de nutrientes nas estações hidroquímicas do Rio Ribeira de Iguape em Agosto/09. 111

FIGURA 48 - Distribuição das concentrações de nutrientes em função da concentração do isótopo de ${ }^{226} \mathrm{Ra}$ nas estações hidroquímicas no sistema estuarino Cananéia-Iguape em Fevereiro/09 ..... 112 FIGURA 49 - Distribuição das concentrações de nutrientes em função da concentração do isótopo $\mathrm{de}^{228} \mathrm{Ra}$ nas estações hidroquímicas no sistema estuarino Cananéia-Iguape em Fevereiro/09 ..... 112 FIGURA 50 - Distribuição das concentrações de nutrientes em função da concentração do isótopo de ${ }^{226} \mathrm{Ra}$ nas estações hidroquímicas no sistema estuarino Cananéia-Iguape em Agosto/09. ......... 113 FIGURA 51 - Distribuição das concentrações de nutrientes em função da concentração do isótopo $\mathrm{de}^{228} \mathrm{Ra}$ nas estações hidroquímicas no sistema estuarino Cananéia-Iguape em Agosto/09. ......... 113 FIGURA 52 - Distribuição das concentrações de nutrientes em função da concentração do isótopo de ${ }^{226}$ Ra nas águas subterrâneas de Cananéia, Iguape e Ilha Comprida Abril/09 114 FIGURA 53 - Distribuição das concentrações de nutrientes em função da concentração do isótopo de ${ }^{228}$ Ra nas águas subterrâneas de Cananéia, Iguape e Ilha Comprida Abril/09 114 FIGURA 54 - Distribuição das concentrações de nutrientes em função da concentração do isótopo 
de ${ }^{226}$ Ra nas águas subterrâneas de Cananéia, Iguape e Ilha Comprida Agosto/09.

FIGURA 55 - Distribuição das concentrações de nutrientes em função da concentração do isótopo de ${ }^{228}$ Ra nas águas subterrâneas de Cananéia, Iguape e Ilha Comprida em Agosto/09.

FIGURA 56 - Distribuição das concentrações de nutrientes em função da concentração do isótopo $\mathrm{de}^{226} \mathrm{Ra}$ nutrientes nas estações hidroquímicas do Rio Ribeira de Iguape em Fevereiro/09. 116 FIGURA 57 - Distribuição das concentrações de nutrientes em função da concentração do isótopo $\mathrm{de}^{228} \mathrm{Ra}$ nutrientes nas estações hidroquímicas do Rio Ribeira de Iguape em Fevereiro/09. 116 FIGURA 58 - Distribuição das concentrações de nutrientes em função da concentração do isótopo de ${ }^{226} \mathrm{Ra}$ nutrientes nas estações hidroquímicas do Rio Ribeira de Iguape em Agosto/09 117 FIGURA 59 - Distribuição das concentrações de nutrientes em função da concentração do isótopo de ${ }^{228}$ Ra nutrientes nas estações hidroquímicas do Rio Ribeira de Iguape em Agosto/09 117 


\section{CAPÍTULO 1 - INTRODUÇÃO E JUSTIFICATIVAS}

As regiões costeiras representam compartimentos ambientais de transição que vêm sendo explorados há muitos anos. A crescente, desorganizada e desenfreada ocupação imobiliária por loteamentos residenciais, industriais e turísticos podem ser elencados como alguns dos principais fatores de poluição e degradação desses ambientes (www.ana.gov.br). A tipologia da zona costeira em regiões tropicais compreende as ressurgências costeiras, os estuários de vários tipos, os manguezais, os marismas, os lagos costeiros, as dunas, as restingas e os recifes. Em regiões tropicais, estuários, manguezais e recifes podem estar espacialmente acoplados, com cada um contribuindo do seu modo para o processamento de matéria durante a sua transferência do continente ao mar.

A interface terra-mar representa um dos sítios que controlam o fluxo de água e matéria do ciclo global. Por definição, compreende três compartimentos: a zona costeira, o continente interno à montante e o oceano aberto à jusante (Knoppers et al., 2009). Os estuários com manguezais e/ou marismas são os sistemas mais freqüentes nas áreas de clima úmido e plataformas passivas, locais onde ocorre a mistura de águas fluviais e marinhas e processamento intensivo da matéria oriunda de ambas as fontes. As suas características geomorfológicas e hidrológicas foram moldadas ao longo do tempo pela interação de energia física da ação das ondas, dos movimentos de maré e do aporte fluvial. Em termos geológicos são sistemas jovens que evoluíram durante o Holoceno, desde 5 a 6 mil anos atrás, em função de episódios de transgressão (avanço) e regressão (recuo) do nível do mar. Alguns evoluíram desde o Pleistoceno-Superior ou por processos tectônicos. $\mathrm{Na}$ classificação geomorfológica-hidrológica dos estuários, estão incluídas as categorias dos deltas, deltas-estuarinos, estuários de vales inundados e de planícies inundadas, lagunas estuarinas e lagunas (Knoppers et al., 2009; Marins et al., 2010). Uma feição característica da costa brasileira é a baía-estuarina, que pela definição se enquadra na categoria de estuários de vales inundados, mas também pode ser de origem tectônica.

Para controlar as descargas de materiais da região continental para o litoral, as organizações de saneamento ambiental estabeleceram padrões de qualidade e implementam programas rotineiros de monitoração dos reservatórios aquáticos, a fim de nortear estratégias da gestão dos recursos hídricos e garantir sua disponibilidade para o 
pleno atendimento da demanda atual e das gerações futuras (www.ana.gov.br). A disseminação das informações hidrológicas, especialmente quanto ao aporte de águas doces e às concentrações de sedimentos em suspensão nas bacias hidrográficas brasileiras, tiveram um grande avanço na última década, sendo compiladas pela Agência Nacional de Águas (ANA). O principal ecossistema continental que abrange a zona costeira brasileira é a Mata Atlântica com 5 a $6 \%$ da floresta original remanescente, sujeita a diversos impactos, tais como a presença de barragens, urbanização, agricultura, industrialização e mineração (Knoppers et al., 2009). O resultado de todos estes impactos se manifesta em mudanças do aporte fluvial de água e matéria para a costa. As barragens retêm e transformam materiais nos seus reservatórios, o desmatamento induz à erosão e incrementa o aporte fluvial de matéria e os outros impactos levam à introdução de efluentes com compostos inorgânicos e orgânicos naturais e artificiais.

A maioria dos rios brasileiros que desemboca na zona costeira possui algum ou múltiplos impactos ambientais nas suas bacias de drenagem. Um dos problemas recentes refere-se à busca de níveis naturais de referência para o entendimento das causas e dos efeitos dos impactos ambientais humanos nestas bacias (Knoppers et al., 2009). Esta tarefa é somente alcançada através de uma análise minuciosa de dados pretéritos em comparação com as condições atuais. Embora o Brasil apresente um grande número de informações disponíveis sobre o aporte fluvial de água e sedimentos, ainda faltam informações sobre o aporte de compostos inorgânicos (incluindo a distribuição de radionuclídeos naturais) e orgânicos, que possam ser utilizadas para estimativas do potencial de fertilização dos rios para a sustentação da produtividade primária e avaliação do potencial de contaminação humana da zona costeira. No setor Sul da plataforma brasileira, situado entre o Cabo de São Tomé $\left(22^{\circ} \mathrm{S}\right)$ e o Chuí $\left(34^{\circ} \mathrm{S}\right)$, o aporte de parte da bacia do Atlântico Sudeste e da bacia do Atlântico Sul contribui com $146 \mathrm{~km}^{3}$ ano $^{-1}$ de água doce $\left(602 \mathrm{~mm} \mathrm{ano}{ }^{-1}\right)$. As feições dominantes neste setor incluem a proximidade do complexo cristalino da Serra do Mar no litoral do Rio de Janeiro até o Paraná e as lagunas da planície litorânea do Rio Grande do Sul. Dentre estas, destaca-se a presença da Lagoa dos Patos, que tem o Rio Guaíba como principal contribuinte, cujo aporte fluvial representa mais de $50 \%$ de todo o aporte à Plataforma Sul (Windom et al., 2000).

Embora muito se tenha evoluído nas últimas décadas na obtenção e disseminação das informações hidrológicas, dados sobre o aporte de sedimentos nas bacias de drenagem 
brasileiras permanecem relativamente escassos (Rodrigues et al., 2003). A maior parte dos estudos favoreceu a obtenção de dados para o setor energético, visando à avaliação do assoreamento de reservatórios, negligenciando a importância do aporte de sedimentos na fertilização e estabilização da zona costeira. Estimativas de caráter pontual ao longo da costa brasileira mostram que os aportes de sedimentos variam de $0,02 \times 10^{6} \mathrm{t} \mathrm{ano}^{-1}$, no Rio Jaguaribe sob o impacto do clima semi-árido e de centenas de reservatórios, até os $1.200 \mathrm{x}$ $10^{6} \mathrm{t} \mathrm{ano}^{-1}$ do Rio Amazonas. No caso particular do Rio Ribeira de Iguape, o aporte varia

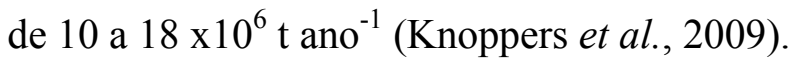

As águas subterrâneas constituem um elemento ambiental muito sensível às alterações no meio. Uma vez modificadas suas condições naturais, a dinâmica do fluxo subterrâneo torna bastante fácil a disseminação de vários constituintes, incluindo aqueles considerados tóxicos no ponto de vista ambiental para os corpos receptores aquáticos. Desta maneira, é fundamental o conhecimento das condicionantes naturais do fluxo subterrâneo, incluindo materiais (solos e rochas), propriedades hidráulicas e estruturais. Ao longo do seu trajeto no ambiente, a composição química original das águas é modificada em função do contato com materiais de diversas tipologias, tanto em decorrência de eventos naturais, quanto àqueles induzidos pela ação humana, dentre os quais pode se citar a erosão, a mineração e a agricultura. Em virtude destas transformações, algumas fontes de água podem incorporar em sua composição concentrações demasiadamente aumentadas de metais tóxicos e pesticidas. As relações que se estabelecem entre a água subterrânea, o substrato através do qual ela percola e as águas de superfície receptoras são de grande importância ambiental. Excetuando-se alguns poucos locais (Burnett et al., 2003; Burnett et al., 2006; Burnett et al., 2008; Moore \& Oliveira, 2008) aonde essas estimativas já foram realizadas, não existem dados disponíveis na literatura referentes a este assunto ao longo da maior parte das regiões costeiras do mundo (UNESCO, 2004; SCOR, 2006; IAEA, 2008).

Uma das formas de avaliação da quantidade de material transferida para o oceano por meio dos fluídos subterrâneos consiste na utilização de traçadores. Estes elementos geralmente se encontram em altas concentrações nos fluídos subterrâneos quando comparados com a água circundante e possuem baixa reatividade química no oceano. Os quatro isótopos naturais de Ra satisfazem estes critérios e podem ser utilizados como traçadores naturais da troca de fluídos em regiões costeiras. Vários autores utilizaram estes traçadores para determinar taxas de transporte e fluxos de material em estudos científicos 
realizados em cenários estuarinos e oceânicos, aonde as concentrações, decaimento e diluição das atividades dos isótopos naturais de Ra e difusão molecular dos sedimentos foram modelados (Burnett et al., 2003; Burnett et al., 2006; Burnett \& Dulaiova, 2006; Burnett et al., 2008).

Quando se utilizam os isótopos de Ra como traçadores ambientais, vários parâmetros complementares devem ser medidos ou definidos, incluindo as condições da área de influência (área, volume), a composição química da água, as entradas e retiradas desses elementos do sistema, o tempo de residência da água superficial e as razões de atividade iniciais dos elementos de interesse na região-fonte. As concentrações iniciais incluem aquelas presentes na água do mar, dos rios, subterrânea, chuva, produção in situ, transporte horizontal da coluna d'água, mistura e ressuspensão dos sedimentos ou difusão dos sedimentos do fundo. As retiradas incluem o decaimento in situ, transporte horizontal da coluna d'água, vórtices de difusão horizontal e vertical e evasão para a atmosfera (Cable et al., 1996; Burnett et al., 2006). Através de modelos de caixa simples e de um balanço de massas incorporando a advecção dos sedimentos e o transporte na coluna d'água, a aproximação geoquímica pode representar um método sensível para se estimar a contribuição da água subterrânea para os fluxos de vários constituintes na região costeira.

A partir da descarga de águas subterrâneas, (cuja sigla em inglês é "SGD" e significa "Submarine Groundwater Discharge") (UNESCO, 2004) várias substâncias dissolvidas podem ser transportadas para águas superficiais. Deste modo, esgotos domésticos, efluentes industriais e outros rejeitos solúveis que percolam um dado aqǘfero podem eventualmente atingir e contaminar as águas costeiras. O impacto ecológico destas descargas em águas costeiras dependerá das concentrações dos poluentes originalmente dissolvidos e das vias de infiltração destas plumas de contaminação (Bokuniewicz et al., 2003).

Nos últimos 20 anos, a contribuição da descarga de águas subterrâneas para o oceano foi documentada, embora ainda existam grandes dificuldades de se quantificar o seu fluxo total em uma escala regional devido a própria natureza desse fenômeno (Moore, 1996; Moore, 1997; Moore \& Shaw, 1998; Moore, 1999). Vários trabalhos conduzidos na Índia, nos Estados Unidos e no Brasil (Rama \& Moore, 1996; Moore, 1999; Oliveira et al., 2006; Moore \& Oliveira, 2008) demonstraram que os isótopos de Ra poderiam ser 
aplicados como traçadores geoquímicos da descarga de água subterrânea no ambiente marinho.

Os isótopos de Ra têm características peculiares, que lhes permitem ser aplicados em estudos da SGD, uma vez que apresentam concentrações elevadas nas águas subterrâneas e baixa reatividade no ambiente marinho. Em um cenário simples, conhecendo-se os inventários das concentrações de Ra na região de interesse, pode-se identificar e integrar a entrada de água subterrânea em uma grande área. Para transformar a distribuição dos isótopos de $\mathrm{Ra}$ em um fluxo de águas subterrâneas, é preciso também determinar as concentrações destes isótopos na água subterrânea do local e a taxa de mistura das águas costeiras. Quando se assume a hipótese de que o sistema estudado está em balanço (estado estacionário), a taxa na qual os isótopos de Ra são removidos por mistura costa afora deve ser igual à taxa na qual eles estão sendo adicionados próximo da costa. Deste modo, medindo-se os termos envolvidos neste balanço de massas, pode se quantificar o fluxo de águas subterrâneas. Ao se detectar qualquer sinal anômalo da atividade de Ra nas águas costeiras, pode se localizar um sítio de descarga submarino, aonde o excesso da concentração de $\mathrm{Ra}$ deve ser proveniente do aqüífero fluindo livremente em contato com o fundo do mar.

O Ra é especialmente útil para estudos da SGD onde a mistura de águas doces e águas salgadas ocorre sob a superfície. Os isótopos de meias-vidas curtas, ${ }^{223} \mathrm{Ra}$ (meia-vida de 11,4 dias) e ${ }^{224} \mathrm{Ra}$ (meia-vida de 3,66 dias), são continuamente regenerados do decaimento de seu respectivo isótopo de Th precursor, que está adsorvido na superfície dos sedimentos, materiais particulados ou nos sólidos dos aqüíferos. Devido suas meias-vidas relativamente curtas, os isótopos ${ }^{223} \mathrm{Ra} \mathrm{e}^{224} \mathrm{Ra}$, têm uma aplicação restrita como traçadores do tempo de mistura de águas próximas da costa (Moore \& Oliveira, 2008). Os gradientes dos isótopos de Ra de meias-vidas longas costa afora, ${ }^{226} \mathrm{Ra}$ e ${ }^{228} \mathrm{Ra}$, podem ser combinados com as taxas de troca dos isótopos de meias-vidas curtas, fornecendo uma estimativa dos fluxos de Ra para o oceano.

Avaliar os fluxos via água subterrânea de espécies químicas reativas é um grande desafio para os estudos realizados em diferentes áreas de conhecimento. Vários trabalhos oceanográficos e hidrológicos negligenciaram no passado a contribuição desse fluxo para os balanços de massas na zona costeira, devido à dificuldade inerente a sua medida. 
Somente na última década reconheceu-se cientificamente que, em alguns casos, a descarga de águas subterrâneas pode ser relevante quanto ao seu volume e a sua composição química. Estimativas da descarga de águas subterrâneas variam amplamente ao redor do mundo, com alguns fluxos correspondendo a $10 \%$ do volume total descarregado no mar pelos rios (UNESCO, 2004).

A importância científica potencial dos quatro isótopos naturais de $\mathrm{Ra}$ como traçadores dos mecanismos de transferência rocha-água e do transporte de vários constituintes em aqüíferos, reside no fato destes elementos constituírem ferramentas para a obtenção de informações valiosas dos processos que ocorrem na interface continenteoceano (Burnett et al., 2006; Moore \& Oliveira, 2008). Geralmente, as razões de atividade ${ }^{228} \mathrm{Ra} /{ }^{226} \mathrm{Ra}$ na água subterrânea estão relacionadas às razões de atividade $\mathrm{Th} / \mathrm{U}$ presentes na rocha hospedeira. Este parâmetro é um indicador das características do aqüífero e das reações físicas e químicas que ocorrem no sistema rocha-água (Bonotto \& Silveira, 2006).

\subsection{Elementos-traço, radionuclídeos e contaminantes na interface continente-oceano}

Vários estudos multidisciplinares têm sido conduzidos em regiões costeiras ao nível mundial, com os propósitos de melhor compreender, avaliar e mitigar alterações induzidas pelo homem em ambientes continentais e marinhos. Esses trabalhos têm demonstrado que aproximadamente $80 \%$ da carga de poluição para os oceanos se originam de atividades terrestres. Esse dado enaltece a necessidade urgente de um planejamento e tomada de ações que viabilizem o desenvolvimento ecologicamente sustentável da zona costeira, protegendo o ambiente marinho (UNESCO, 2004).

Cerca de $3 / 4$ do globo terrestre é coberto pelos oceanos. Para melhor compreender a química desta vasta quantidade de água, geoquímicos marinhos e oceanógrafos químicos tem realizado expedições a fim de coletar informações e estabelecer os perfis de elementos-traço e isótopos no oceano. Entretanto, estes estudos isolados não estabelecem necessariamente as naturezas químicas e as inter-relações destes elementos no ambiente marinho. Impulsionados por preocupações recentes a respeito das mudanças climáticas que podem afetar a química dos oceanos e em posse de muitos avanços tecnológicos para a realização de pesquisa oceanográfica, cientistas do mundo todo esperam identificar estes 
processos no Projeto GEOTRACES - “An International Study of the Marine Biogeochemical Cycles of Trace Elements and Isotopes". O projeto é financiado pelo SCOR - Scientific Committee on Oceanic Research (http://www.geotraces.org) (SCOR, 2006).

Elementos-traço incluindo $\mathrm{Fe}, \mathrm{Al}, \mathrm{Mn}, \mathrm{Cd}$ e $\mathrm{Nd}$ ou isótopos estáveis como ${ }^{15} \mathrm{~N}$ e ${ }^{13} \mathrm{C}$ fornecem informações únicas a respeito das fontes continentais destes elementos para o oceano. Radioisótopos como o ${ }^{234} \mathrm{Th}$ e o ${ }^{226} \mathrm{Ra}$ fornecem informações a respeito das prováveis fontes de elementos-traço e as taxas pelas quais eles adsorvem em várias partículas oceânicas orgânicas e inorgânicas.

Nas últimas décadas, os ciclos marinhos dos macro-nutrientes (fosfato, silicato e nitrato) foram amplamente investigados e encontram-se razoavelmente bem conhecidos ao nível mundial (Braga, 2002). Em contraste, existem dados escassos a respeito do comportamento de formas orgânicas de nitrogênio e de fósforo, os quais se encontram freqüentemente complexados com compostos dissolvidos de carbono (DOC) e associados aos elementos-traço e isótopos (SCOR, 2006). Por exemplo, a compreensão da importância de alguns micro-nutrientes como reguladores dos ciclos biogeoquímicos marinhos continua incipiente. A comunidade científica aceitou que o suprimento de Fe limita a produtividade total em regiões cujas águas da superfície do oceano são ricas em nutrientes e empobrecidas em clorofila. $\mathrm{O}$ Fe tem sido relacionado ainda a vários outros processos que ocorrem nestes ecossistemas (Martin et al., 1990). Experimentos in situ e em laboratório indicam que outros metais-traço podem estar relacionados e controlar a ocorrência de vários processos no oceano, particularmente $\mathrm{Cu}, \mathrm{Zn}, \mathrm{Co}, \mathrm{Cd}$ e $\mathrm{Mn}$ (Morel et al., 2003; Morel \& Price, 2003). A ciclagem destes micro-nutrientes é fundamental para compreender os processos estuarinos e oceânicos, pois controlam não somente a produtividade, mas também as tipologias e funções destes processos. Desta forma, sabe-se que os fluxos de micro-nutrientes exercem papel relevante para regular os ciclos dos macro-constituintes como $\mathrm{N}$ e $\mathrm{C}$, imprescindíveis para o entendimento da vida e dos fluxos de carbono no oceano (SCOR, 2006).

A compreensão da dinâmica de compostos nitrogenados é extremamente importante para se determinar o status ecológico de sistemas fluviais e estuários (Gardolinski et al., 2002). A eutroficação é o fenômeno mais preocupante nestes 
ecossistemas e é fortemente influenciada por atividades tais como a agricultura e aumento da densidade demográfica. Os compostos nitrogenados adentram os estuários a partir de várias fontes naturais e antrópicas. $\mathrm{O}$ gás $\mathrm{N}_{2}$ elementar é a forma de nitrogênio mais abundante em águas estuarinas, mas devido aos processos biogeoquímicos e suas transformações, as formas mais comumente encontradas são de compostos inorgânicos dissolvidos, ou seja, nitrato, nitrito e amônia, além de compostos orgânicos nitrogenados (nas formas dissolvidas e particuladas). Algumas espécies de bactérias e algas azuis podem fixar nitrogênio gasoso, convertendo-o a um composto de nitrogênio orgânico e tornando-o disponível a outras espécies. O nitrato constitui a forma de nitrogênio inorgânico dissolvido predominante na maior parte das águas estuarinas e é oriundo do intemperismo das rochas, deposição atmosférica, escoamento superficial difuso de terras agricultáveis ou outras fontes de descarga pontuais (Gardolinski et al., 2002).

Os radionuclídeos da série de decaimento do ${ }^{238} \mathrm{U}$ são elementos radioativos naturais e se encontram disseminados no ambiente em quantidades de traços. $\mathrm{O}$ isótopo ${ }^{226} \mathrm{Ra}$, um elemento intermediário da série do ${ }^{238} \mathrm{U}$, está presente na crosta terrestre e decai para ${ }^{222} \mathrm{Rn}$, que, após sucessivos decaimentos forma o ${ }^{210} \mathrm{~Pb}$ ( FIG. 1).

Os sedimentos são geralmente o local de depósito dos radionuclídeos no ambiente aquático. A adsorção dos radionuclídeos dissolvidos da água para o material particulado é um importante mecanismo que reduz a disponibilidade destes elementos para a biota aquática que habita a coluna d'água e, conseqüentemente, seu acúmulo nas cadeias alimentares marinhas. Entretanto, para os organismos dos bentos, este acúmulo nos sedimentos pode representar um problema, já que muitos organismos bentônicos fazem parte da dieta alimentar de alguns peixes (Holby \& Evans, 1996). 


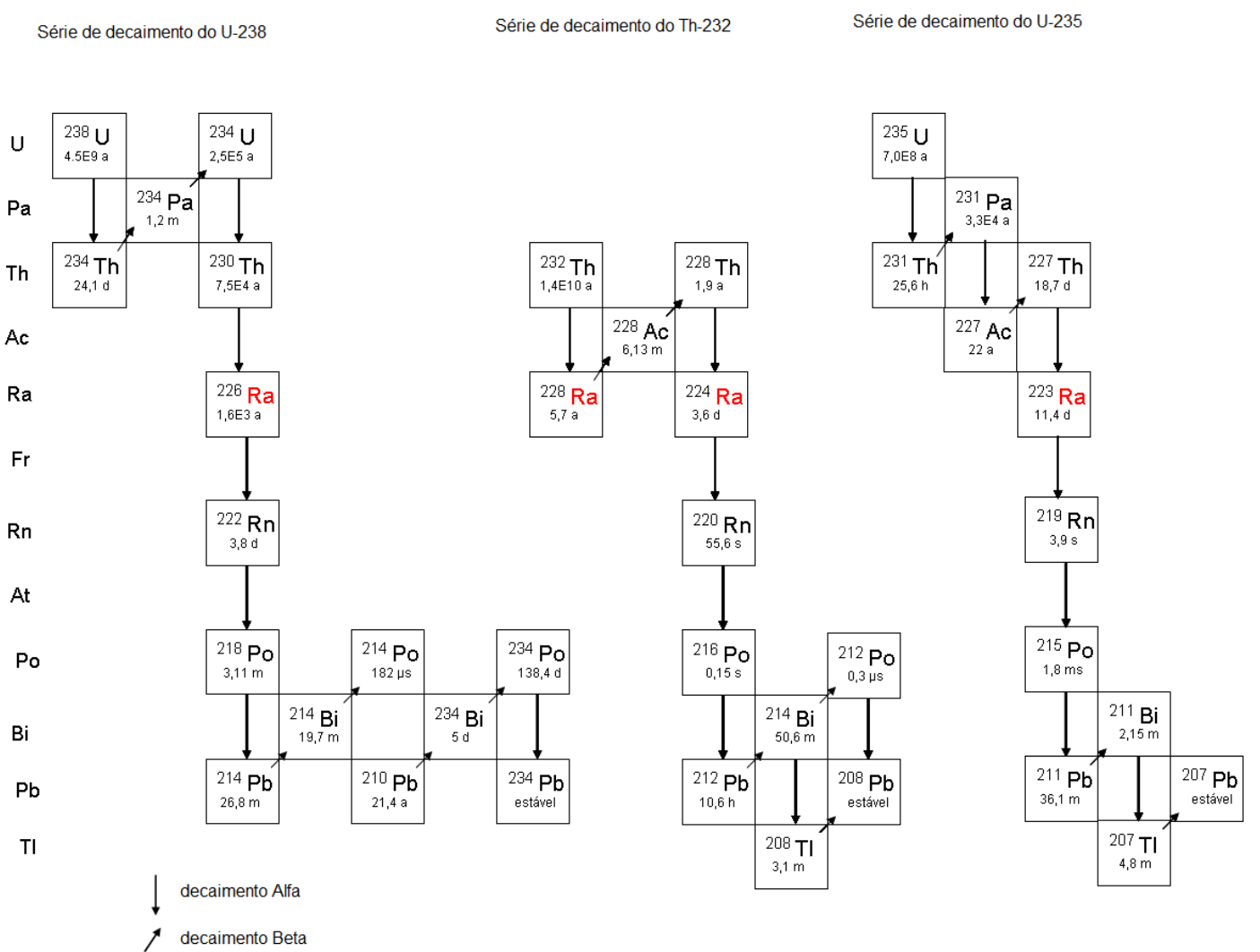

FIGURA 1 - Esquema de decaimento radioativo das séries do ${ }^{238} \mathrm{U},{ }^{232} \mathrm{Th}$ e ${ }^{235} \mathrm{U}$ com os respectivos isótopos de Ra destacados.

Quando os radionuclídeos são introduzidos no meio ambiente, eles são dispersos, diluídos e redistribuídos, podendo permanecer em solução, serem ingeridos pelos organismos vivos ou adsorvidos em partículas dispersas em suspensão, dependendo das características ambientais, das suas diferentes propriedades químicas e do comportamento destes elementos em nível de traços, que são afetados por leis de adsorção, formação de colóides e outros processos. Dessa forma, a água se torna o principal agente transportador dos elementos radioativos sob várias condições geoquímicas e geofísicas. A infiltração desses elementos começa nas reações que ocorrem no contorno dos grãos e ataque dos retículos cristalinos dos materiais, sendo facilitada quando as rochas apresentam microfraturas causadas por processos tectônicos e térmicos, muitas vezes cíclicos. Os materiais atacados com maior facilidade são aqueles que contêm elementos alcalinos ou alcalinos terrosos, que são enriquecidos com elementos radioativos (Bonotto \& Silveira, 2006).

Os mecanismos de transporte e distribuição dos radionuclídeos naturais e artificiais no oceano irão depender de uma seqüência de parâmetros intrínsecos da meia-vida, assim como das interações dos radionuclídeos com as fases dissolvidas e particuladas. Alguns 
radionuclídeos podem ser classificados como traçadores conservativos, quando apresentarem a tendência de permanecer solúveis na massa d'água, seguir seu movimento, e serem transportados a longas distâncias, ou não-conservativos, quando apresentarem uma afinidade acentuada com o sedimento, material em suspensão e/ou a biota. Logo, eles apresentam uma aplicação limitada da área de influência no entorno do ponto de sua liberação (Santschi et al., 1989).

Na região de transição continente-oceano, os elementos-traço radioativos podem ser facilmente introduzidos no ambiente marinho através da deposição atmosférica, erosão dos solos e sedimentos, escoamento superficial, lixiviação e descarga de águas subterrâneas. As atividades humanas, cada vez mais intensas, têm provocado alterações significativas nestes fluxos. Estudos sobre a taxa de sedimentação são também, importantes para a compreensão da dinâmica que envolve a dispersão de elementos-traço e radionuclídeos originários de diversas fontes nos ambientes aquáticos (Damatto, 2010).

Os radionuclídeos naturais das séries do ${ }^{238} \mathrm{U}$ e do ${ }^{232} \mathrm{Th}$ tem sido utilizados em larga escala e com excelentes resultados para se estimar a contribuição do aporte de substâncias naturais e antrópicas para a região costeira. Traçadores geoquímicos naturais como o ${ }^{222} \mathrm{Rn}$ e o ${ }^{226} \mathrm{Ra}$, quando determinados em águas costeiras, são vantajosos em estimativas regionais, uma vez que os seus sinais representam valores integrados na coluna d'água. Estes radionuclídeos encontram-se enriquecidos na água subterrânea, podem ser detectados em concentrações muito baixas e são conservativos (Burnett et al., 2006; Moore \& Oliveira, 2008).

Embora o Th seja um radionuclídeo mais abundante na crosta terrestre do que o U, em águas doces o Th é geralmente encontrado em concentrações inferiores às do U (Bonotto \& Silveira, 2006). O Th que ocorre naturalmente no meio ambiente consiste de um único isótopo, o ${ }^{232} \mathrm{Th}$, com uma meia-vida de 14.200 milhões de anos. O urânio natural consiste de dois isótopos, ${ }^{238} \mathrm{U}$ (meia-vida de 4.510 milhões de anos) e ${ }^{235} \mathrm{U}$ (meiavida de 713 milhões de anos), com abundâncias relativas no presente momento de 99,27\% e $0,72 \%$, respectivamente. $\mathrm{O}$ isótopo ${ }^{234} \mathrm{U}$ é radiogênico, sendo produzido na série do ${ }^{238} \mathrm{U}$. A forma de urânio mais lábil para ambientes aquáticos é o $\mathrm{U}^{6+}$, quase sempre encontrado na forma de radical uranila, $\mathrm{UO}_{2}{ }^{2+}$. Para os valores de $\mathrm{pH}$ mais comumente encontrados no ambiente exógeno (entre 4 e 9), o mineral uraninita é extremamente insolúvel em águas 
naturais e o íon $\mathrm{U}^{4+}$ permanece praticamente imóvel em solução. Em águas naturais, os principais complexos de uranila são formados com flúor (em condições ácidas), fosfato (em condições quase neutras) e carbonato (em condições alcalinas), havendo contribuições em menor grau de sulfato e cloreto. Desta forma, os carbonatos de uranila aumentam a solubilidade e conseqüentemente, a migração do U em condições alcalinas, tais como as observadas na água do mar. Considerando que a geoquímica ambiental do Ra depende em grande parte da geoquímica do U e Th no sistema rocha-água, a utilização dos isótopos naturais de $\mathrm{Ra}$ como traçadores em sistemas marinhos, dependerá de suas propriedades químicas, funções-fonte e ainda, da escala de tempo de interesse. Com meias-vidas variando de 3,7 dias $\left({ }^{224} \mathrm{Ra}\right)$ a 1.600 anos $\left({ }^{226} \mathrm{Ra}\right)$, os quatro isótopos naturais de Ra são de grande aplicabilidade no estudo de massas d'água e da descarga de águas subterrâneas na região costeira. Assim sendo, é possível contemplar as entradas de Ra dissolvidas via água subterrânea e dos rios, representando os processos físicos que controlam os fluxos de outros constituintes dissolvidos na água do mar na região de interesse.

\subsection{Ciclagem de elementos-traço em um estuário subterrâneo: geoquímica dos isótopos de Ra na água intersticial}

A monitoração de radionuclídeos naturais no ambiente marinho é realizada pelas análises destes radionuclídeos específicos nas matrizes água do mar, água fluvial, água subterrânea, materiais particulados em suspensão, aerossóis e sedimentos. Dentre os radionuclídeos naturais mais estudados, pode-se citar o ${ }^{226} \mathrm{Ra},{ }^{228} \mathrm{Ra}$ e o ${ }^{40} \mathrm{~K}$, presentes em várias localidades da crosta terrestre, e que possuem altas solubilidades e mobilidade. $\mathrm{O}$ conhecimento acerca destas distribuições tem despertado grande interesse em estudos da contaminação ambiental por fontes naturais de radiotividade.

Nas últimas décadas, os trabalhos versando na aplicação de radionuclídeos naturais em regiões costeiras têm aumentado em virtude da utilidade de vários radioisótopos na determinação de taxas de sedimentação, taxas de difusão ao longo da coluna d'água, constantes de difusão molecular e descarga águas subterrâneas (Broecker \& Peng 1982). Muitos elementos reativos são liberados do material particulado em suspensão e/ ou dos sedimentos durante a mistura estuarina. Neste contexto, as distribuições dos isótopos naturais de Ra têm sido investigadas em vários ecossistemas estuarinos e costeiros (Moore \& Shaw, 1998). 
Existem quatro isótopos naturais de Ra: o ${ }^{226} \mathrm{Ra}$ (meia-vida de 1.600 anos), emissor de partículas alfa, membro da série de decaimento radioativo do ${ }^{238} \mathrm{U}$; o ${ }^{223} \mathrm{Ra}$ (meia-vida de 11,4 dias), emissor de partículas alfa da série de decaimento radioativo do ${ }^{235} \mathrm{U}$; o ${ }^{224} \mathrm{Ra}$ (meia-vida de 3,66 dias), emissor de partículas alfa da série de decaimento radioativo do ${ }^{232} \mathrm{Th}$ e o ${ }^{228} \mathrm{Ra}$ (meia-vida de 5,75 anos), emissor de partículas beta da série de decaimento radioativo do ${ }^{232} \mathrm{Th}$.

Em cenários estuarinos e costeiros, os isótopos de Th, como elementos partículoreativos, se encontram fortemente ligados aos sedimentos, fornecendo para a água continuamente os isótopos de meias-vidas curtas, ${ }^{223} \mathrm{Ra} \mathrm{e}^{224} \mathrm{Ra}$, que são regenerados em poucos dias. Desta maneira, a mistura da água do mar com poucos centímetros da camada superior dos sedimentos na interface continente-oceano costeira fornece ${ }^{223} \mathrm{Ra},{ }^{224} \mathrm{Ra}$ e uma pequena atividade de ${ }^{226} \mathrm{Ra} \mathrm{e}{ }^{228} \mathrm{Ra}$ para o oceano. Em alguns casos, é possível notar que algumas águas costeiras apresentam concentrações de ${ }^{226} \mathrm{Ra}$ muito maiores que aquelas provenientes simplesmente da dessorção deste radionuclídeo dos sedimentos dos rios. Alguns autores têm proposto que a descarga de água subterrânea salinizada na região costeira é a fonte destas concentrações de ${ }^{226} \mathrm{Ra}$ em excesso (Moore, 1996; Rama \& Moore, 1996).

Os membros das séries radioativas naturais do ${ }^{238} \mathrm{U},{ }^{232} \mathrm{Th}$ e ${ }^{235} \mathrm{U}$ encontram-se envolvidos em processos de transmutação, em que são formados elementos com características físico-químicas completamente diferentes. Num sistema fechado, sem interações com outros componentes ambientais, as séries podem ser encontradas em equilíbrio radioativo, isto é, as atividades de todos os radionuclídeos da série são iguais. No entanto, em ambientes abertos, as características físico-químicas dos radioisótopos são responsáveis pelo estabelecimento do desequilíbrio radioativo (Rama \& Moore, 1996).

As diferenças no comportamento químico do Ra em sistemas fluviais em relação à água do mar são resultado da alteração do coeficiente de adsorção do Ra da água doce para a água salgada. Medidas das concentrações de ${ }^{226} \mathrm{Ra}$ em sistemas estuarinos demonstram que as concentrações deste isótopo no estuário são superiores àquelas observadas nos rios e no oceano (Li et al., 1977). 
Diferentes dos isótopos de $\mathrm{Ra}$ de meias-vidas curtas $\left({ }^{223} \mathrm{Ra}\right.$ e $\left.{ }^{224} \mathrm{Ra}\right)$, os isótopos ${ }^{226} \mathrm{Ra} \mathrm{e}{ }^{228} \mathrm{Ra}$ praticamente não apresentam decréscimo em suas atividades por decaimento radioativo antes de alcançar a margem continental. Estas diferenças nas taxas de decaimento são significativas e responsáveis, em alguns casos, pelo uso limitado destes isótopos em modelos descritivos do comportamento hidrodinâmico à grandes distâncias da costa (Moore, 1999). No caso dos isótopos de Ra de meias-vidas curtas, a diminuição da suas concentrações em função do decaimento em curto prazo é compensada por seu aporte contínuo na massa d'água a partir dos sedimentos ricos em isótopos de Th nas imediações, promovendo uma regeneração quantitativa com rapidez.

$\mathrm{O}^{226} \mathrm{Ra}$ e o ${ }^{222} \mathrm{Rn}$ são os radionuclídeos mais freqüentemente encontrados em águas subterrâneas e superficiais.A grande dispersão dos valores de concentração de ${ }^{226} \mathrm{Ra},{ }^{228} \mathrm{Ra}$ $\mathrm{e}^{222} \mathrm{Rn}$ em águas subterrâneas está relacionada aos processos de interação entre as rochas de um dado aqüífero e a água subterrânea em contato com as primeiras. Nestas águas, o desequilíbrio geralmente observado entre os isótopos ${ }^{226} \mathrm{Ra}$ e ${ }^{228} \mathrm{Ra}$, assim como entre ${ }^{226} \mathrm{Ra}$ $\mathrm{e}^{222} \mathrm{Rn}$, sugerem que o recuo alfa é um processo responsável pela transferência do Ra e do Rn da fase sólida para a fase aquosa. Uma vez em solução, as concentrações de Ra são controladas pelas reações de adsorção e dessorção com as superfícies das rochas que compõe o aqüífero ou em alguns casos específicos, como no caso de águas subterrâneas com altos teores de sulfato e carbonato, pelos processos de co-precipitação do Ra com estes sais (Bonotto \& Silveira, 2006).

Em vários estudos observou-se que a razão de atividade ${ }^{222} \mathrm{Rn} /{ }^{226} \mathrm{Ra}$ decresce com o respectivo aumento relativo das concentrações de ${ }^{226} \mathrm{Ra}$ e de ${ }^{222} \mathrm{Rn}$, implicando que quanto mais distante o ponto de amostragem estiver da área enriquecida em ${ }^{226} \mathrm{Ra}$, maior a é valor da razão ${ }^{222} \mathrm{Rn} /{ }^{226} \mathrm{Ra}$ medido na água subterrânea. Estes dados sugerem que a migração do ${ }^{222} \mathrm{Rn}$ pode ser bem maior que a do ${ }^{226} \mathrm{Ra}$ transportado pela água subterrânea, mesmo quando se considera que a meia-vida física do ${ }^{226} \mathrm{Ra}$ é muito mais longa. Isto demonstra que o transporte do Ra pela água subterrânea pode ser extremamente limitado em função da distância, dependendo continuamente das trocas físico-químicas que ocorrem com os sólidos do aqüífero e materiais em suspensão (Oliveira, 1998).

Apesar da descarga de águas subterrâneas constituírem uma fonte relevante de elementos dissolvidos para o oceano, ainda muito pouco se conhece a respeito das reações 
químicas que controlam o seu fluxo em aqüíferos costeiros. O fluxo líquido de elementos fornecidos pela SGD para a zona costeira é dependente das reações biogeoquímicas que ocorrem na zona de mistura água subterrânea-água do mar. Estas interações que ocorrem nos denominados "estuários subterrâneos" podem ser interpretadas tanto sob a perspectiva da composição dos perfis de sedimentos, quanto da óptica da composição da água intersticial que permeia a coluna sedimentar.

Vários processos geoquímicos importantes na superfície terrestre ocorrem nas zonas de transição (interface) entre ambientes. Um dos cenários de transição que tem recebido atenção limitada é zona subterrânea costeira, aonde também ocorrem as misturas água doce-água salgada, porém não tão evidentes quanto aquelas normalmente observadas nos "estuários superficiais". A importância potencial dessa região, definida por alguns autores como "estuários subterrâneos" (Moore, 1999), é que os fluxos geoquímicos associados ao transporte de água e as inter-relações que ocorrem nestes cenários foram muito pouco investigadas, principalmente em virtude da dificuldade associada à amostragem. Trabalhos recentes indicam que as interações que ocorrem na interface água subterrânea-água do mar podem ser responsáveis por elucidar o balanço de massas do Ba, $\mathrm{Ra}$ e $\mathrm{Sr}$ no oceano (Charette et al., 2005). Este fato reforça a necessidade de se reavaliar as fontes de sumidouros destes e de outros elementos inorgânicos, levando-se em consideração os processos que ocorrem nos "estuários subterrâneos".

A composição da água intersticial de um "estuário subterrâneo" quando analisada simultaneamente à composição das águas de superfície e subterrânea, pode ser utilizada para se obter uma macro-visão da química estuarina, tão bem como, compreender as reações químicas de diagênese do $\mathrm{Fe}, \mathrm{Mn}, \mathrm{U}, \mathrm{Ba}$ e $\mathrm{Sr}$ em aqüíferos costeiros.

Alguns trabalhos na literatura (Charette et al., 2005) evidenciaram acréscimos nãoconservativos de $\mathrm{Ba}$ e Sr na zona de transição em função do aumento da salinidade no “estuário subterrâneo". Entretanto, a extensão da liberação do Sr foi significativamente menor que a de seu análogo alcalino-terroso Ba. A liberação aumentada de Ba na zona de mistura é freqüentemente atribuída a processos de troca-iônica, aonde os cátions presentes na água do mar reagem com o Ba ligado ao material argiloso em suspensão, em salinidades baixas e intermediárias. Alguns resultados sugerem que a dissolução de óxidos de Mn, em conjunção com alterações na salinidade, pode ser um processo importante para a 
manutenção das concentrações aumentadas de Ba nas águas dos "estuários subterrâneos" (Moore \& Shaw, 1998; Moore, 1999). Em contraste, os mesmos trabalhos revelam que as águas intersticiais dos "estuários subterrâneos" são ligeiramente depletadas em U, como um resultado da circulação de águas salinas da SGD através de sedimentos permeáveis redutores.

Uma série de trabalhos foi conduzida para investigar se o transporte de $\mathrm{Ba}$ e $\mathrm{Ra}$ poderia ser influenciado pela descarga de águas subterrâneas e contribuir para um aumento significativo de suas concentrações em estuários e na plataforma continental (Moore, 1996; Moore, 1997; Moore \& Shaw, 1998; Shaw et al., 1998; Moore, 1999). Os resultados obtidos nestas pesquisas evidenciaram que existem dois processos biogeoquímicos que podem ser responsáveis pelo aumento das concentrações de $\mathrm{Ba}$ e $\mathrm{Ra}$. O primeiro processo envolve a liberação de $\mathrm{Ba}$ e Ra da fase dissolvida por reações de troca-iônica que ocorrem durante a intrusão de água salgada nos aqüíferos costeiros. Shaw et al. (1998) e Moore (1999) também sugeriram que a liberação do $\mathrm{Ra}$ e do $\mathrm{Ba}$ nos aqüíferos costeiros via descarga de águas subterrâneas poderia ser influenciada pelo ciclos de redução dos óxidos de Fe e Mn. O mecanismo envolvido neste processo é a adsorção do Ra e do Ba nos óxidos destes metais em condições oxidantes e a sua dessorção em condições redutoras (anóxicas).

\subsection{Objetivos do presente trabalho}

Um conjunto de radionuclídeos que ocorrem naturalmente nas séries radioativas do $\mathrm{U} / \mathrm{Th}\left({ }^{223} \mathrm{Ra},{ }^{224} \mathrm{Ra},{ }^{226} \mathrm{Ra}\right.$ e $\left.{ }^{228} \mathrm{Ra}\right)$ foram estudados em amostras de água de superfície, água subterrânea e água do mar durante as estações seca e chuvosa na região do Vale do Ribeira, litoral sul do Estado de São Paulo, com a finalidade de utilizá-los como traçadores de descargas fluvial e subterrânea para o complexo estuarino-lagunar de Cananéia/Iguape. O inventário destes elementos nas águas da região é desconhecido até o presente momento. As trocas complexas da água subterrânea/água de superfície na bacia do Rio Ribeira de Iguape, assim como os fluxos de vários constituintes para o complexo estuarino-lagunar de Cananéia/Iguape ainda são ainda componentes pouco conhecidos nos balanços hídrico e de materiais no cenário de interesse. 
Na região do Vale do Ribeira, localizada ao sul do Estado de São Paulo, existem vários aqüíferos cársticos, nascentes de águas subterrâneas observadas na maior parte das cavernas paulistas situadas no Parque Estadual Turístico do Alto Ribeira (PETAR). Ao longo do seu percurso, estas águas formam rios que deságuam no complexo estuarinolagunar de Cananéia/ Iguape. Este complexo é uma região dotada de uma reserva natural protegida que apresenta diferenças em sua porção norte em relação ao sul. Ao norte, localiza-se o Valo Grande, um canal artificial construído para drenar a água do Rio Ribeira de Iguape para o mar pequeno. Inicialmente, este canal apresentava uma largura de $3 \mathrm{~m}$, mas atualmente este valor atinge mais de $300 \mathrm{~m}$, em decorrência dos processos de erosão ocasionada pela passagem de um grande volume de água da bacia do Rio Ribeira de Iguape, que drena uma região com intensa atividade agrícola. Este aporte de água tem sido responsável pela alteração das características físicas da água como salinidade e turbidez, sendo também responsável pela alteração da qualidade química da água como as concentrações de nutrientes, micronutrientes e traços. Transporta uma quantidade de material em suspensão que se deposita ao longo do sistema, modificando as condições redox dos sedimentos, os fluxos de nutrientes e os processos microbiológicos associados, fauna e flora locais, com efeitos na produção primária e nas atividades sócio-econômicas da região.

Nesta região, a bacia hidrográfica do Ribeira de Iguape é um importante ecossistema com a maior concentração de Mata Atlântica, onde a disponibilidade de água versus demanda é extremamente positiva. A área de estudo engloba a Unidade de Gerenciamento de Recursos Hídricos - UGRHI 11 - Vale do Ribeira e Litoral Sul, considerada um importante reservatório de água doce, à meia distância das metrópoles Curitiba e São Paulo. É um importante ecossistema para o desenvolvimento regional e estadual, no tocante a disponibilidade de recursos hídricos, contemplando o principal bioma do estado, as áreas urbanas e agrícolas, ainda com pequena atividade industrial. Atualmente, este sistema tem sido estudado sob vários aspectos, principalmente social e ambiental (Programa SOS - Mata Atlântica). Esta área possui um histórico alarmante quanto à contaminação por chumbo, além de ser detentora do mais importante e principal potencial mineral do Estado de São Paulo, com grande variedade de minerais desde ferrosos, metálicos, além de minerais raros como prata, antimônio e terras raras. Isto se reflete nas características geoquímicas da água, dos sedimentos e do material em suspensão. Deste modo a abordagem integrada de ações dentro do tema do presente 
trabalho pretende realizar um inventário, padronizar metodologias de ensaio, promover a capacitação permanente das instituições participantes e disseminar as informações obtidas, com o objetivo de gerar um banco de dados e diretrizes para uma gestão adequada e regionalizada. Deste modo, a avaliação ambiental da bacia pode ser um importante instrumento que poderá contribuir não só para a avaliação da qualidade dos recursos hídricos, como também para o entendimento da dinâmica do sistema e para a escolha de medidas de manejo e recuperação deste ecossistema.

Este trabalho forneceu subsídios a dois projetos de pesquisa financiados pelo Conselho Nacional de Desenvolvimento Científico e Tecnológico (CNPq):

“Impactos biogeoquímicos e sócio-econômicos na região do Complexo Estuarino-Lagunar de Cananéia/ Iguape - com ênfase à influência do Valo Grande", Processo CNPq n $552437 / 2007-7$, coordenado pela Dra. Elisabete de Santis Braga do Instituto Oceanográfico da Universidade de São Paulo.

"Transferência de Materiais na Interface Continente-Oceano", Processo CNPq no 573.601./2008-9, Institutos Nacionais de Ciências e Tecnologia - INCT, coordenado pelo Prof. Dr. Luiz Drude de Lacerda do LABOMAR (Laboratório de Ciências do Mar), da Universidade Federal do Ceará. 


\section{CAPÍTULO 2 - CONTRIBUIÇÃO DA DESCARGA DE ÁGUAS SUBTERRÂNEAS AO APORTE DE MATERIAS EM REGIÕES COSTEIRAS}

\section{1. Águas subterrâneas}

No meio ambiente, várias rochas e compartimentos subterrâneos podem acumular água de diversas origens. A água subterrânea pode ocorrer tanto em rochas consolidadas (ígneas e metamórficas), como em rochas sedimentares não-consolidadas (areias, cascalhos, calcários, etc.). Desta forma, qualquer tipo de rocha pode vir a constituir um aqüífero, desde que apresente condições de armazenar e transmitir água, funcionando tanto como reservatórios quanto como condutores. Um aqüífero geralmente apresenta reservas permanentes e reservas reguladoras de água, que são continuamente abastecidas através da infiltração das chuvas e de outras fontes. As reservas reguladoras correspondem à quantidade de água que se infiltra no aqüífero, provenientes do escoamento de fluidos do nível freático dos rios (ANA, 2002).

A litologia do aqüífero, ou seja, a sua constituição geológica, influencia caracteristicamente a velocidade da água no meio poroso, a qualidade da água armazenada e a sua capacidade como reservatório. Como a litologia aqüífero é função da geologia da rocha matriz, a tipologia dos aqüíferos é determinada pelas rochas que o compõem, dentre as quais pode-se citar: rochas sedimentares (de origem fluvial, lacustre, eólica, glacial e aluvial); rochas ígneas fraturadas (de origem vulcânica), ou rochas metamórficas (rochas calcárias) (Borghetti et al., 2004).

Os aqüíferos porosos ou sedimentares são formados por rochas sedimentares consolidadas, sedimentos não-consolidados ou solos arenosos, aonde a circulação da água se faz nos poros formados entre os grãos de areia, silte e argila de granulações variadas. Constituem os aqüíferos mais importantes, pela capacidade de armazenar grandes volumes de água e por sua ocorrência em áreas relativamente extensas (Borghetti et al., 2004).

Os aqüíferos fraturados ou fissurais são formados por rochas ígneas, metamórficas e cristalinas, duras e maciças, aonde a circulação da água ocorre nas fraturas, fendas e falhas abertas devido ao movimento tectônico (Borghetti et al., 2004). 
Os aqüíferos cársticos são formados em rochas calcárias ou carbonáticas, nos quais a circulação da água ocorre nas fraturas e outras descontinuidades (diáclases) que resultaram da dissolução do carbonato pela água. Estas aberturas podem atingir grandes dimensões, criando, neste caso, verdadeiros rios subterrâneos (Borghetti et al., 2004).

Dentro do contexto de gestão integrada dos recursos hídricos, considerando-se o ciclo hidrológico, admite-se que a água subterrânea é indissociável das águas de superfície. Deste modo, ressalta-se a importância desta interação para os fins de controle ambiental. Quase toda a água subterrânea existente na Terra tem origem no ciclo hidrológico, isto é, no sistema pelo qual a natureza faz a água circular do oceano para a atmosfera e daí para os continentes, de onde retorna, por vias superficiais e subterrâneas ao oceano (FIG. 2). Este ciclo é governado, no solo e subsolo, pela ação da gravidade, bem como pelo tipo e densidade da cobertura vegetal, da atmosfera, da presença de reservatórios superficiais (rios, lagos, mares e oceanos), e por fatores climáticos.

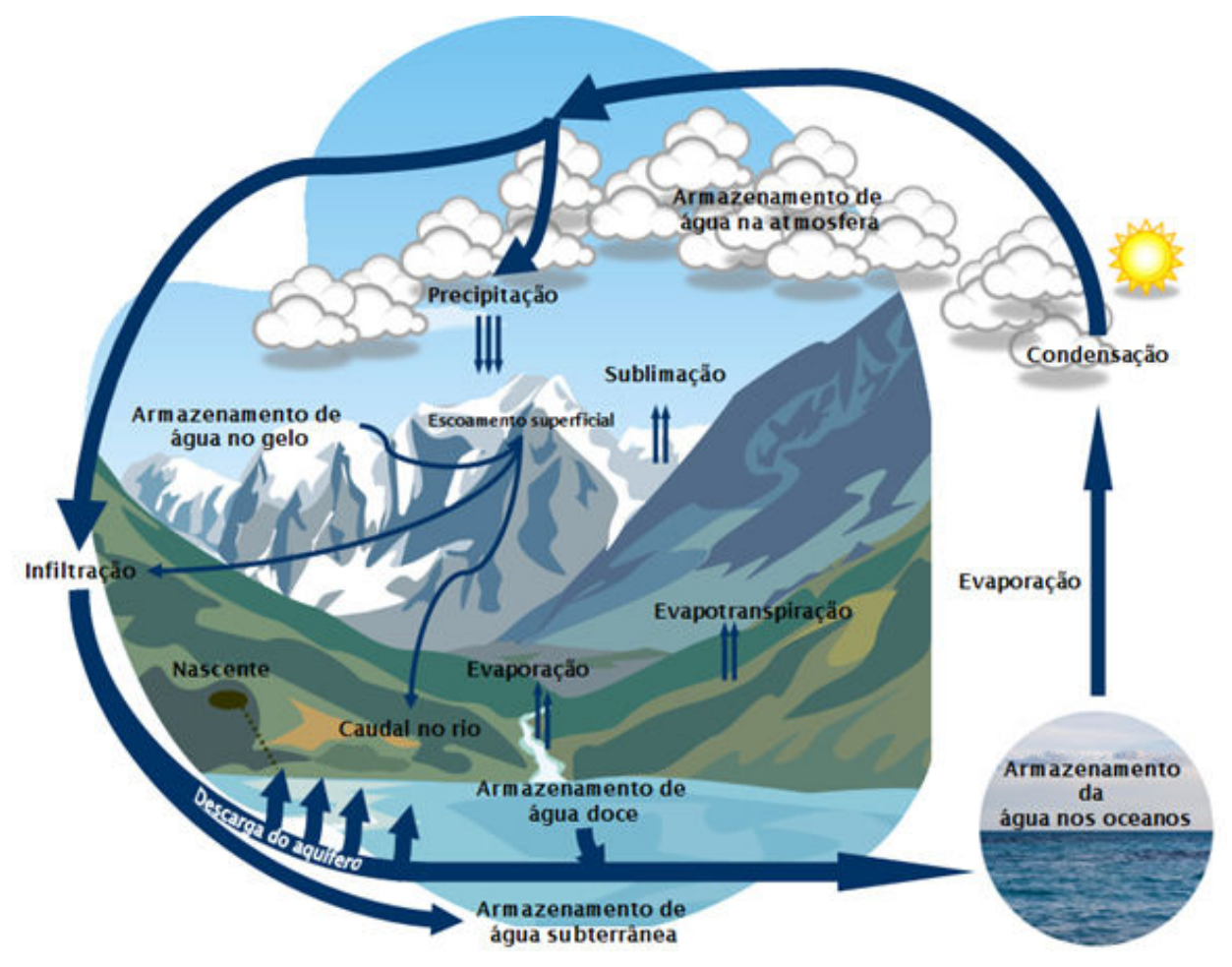

FIGURA 2 - Ciclo Hidrológico (SAA, 2010). 
O nível d'água nos aqüíferos não é estático e geralmente sofre variações devido à precipitação pluviométrica ocorrida, o uso e exploração das águas subterrâneas, efeitos da oscilação das marés nos aqüíferos costeiros, variações súbitas da pressão atmosférica, principalmente no inverno, alterações no regime de escoamento dos rios influentes (que recarregam os aqüíferos), evapotranspiração, etc.

A água subterrânea pode emergir para a superfície e constituir as nascentes, alimentar reservatórios superficiais ou ser descarregada diretamente no oceano. Muitos rios são alimentados por nascentes, o que faz com que esses rios apresentem caudal durante todo o ano, mesmo quando não ocorre precipitação. Os rios podem em determinada altura de seu percurso contribuir para a recarga do aqüífero (rios influentes). Assim, a má qualidade que por vezes se verifica nas águas superficiais pode ser transmitida às águas subterrâneas e vice-versa.

\subsection{Origens, definição e importância da descarga de águas subterrâneas como fonte potencial de materiais para regiões costeiras}

Embora não tão evidente quanto à descarga dos rios, a água subterrânea dos continentes também descarrega diretamente no oceano, sempre que um aqüífero costeiro estiver conectado com o fundo do mar. Aqüíferos artesianos podem se estender através de distâncias consideráveis da costa, debaixo da plataforma continental com descarga para o oceano em seus pontos de surgência (Zektser, 1996). Em alguns, casos estes aqüíferos mais profundos podem se apresentar fraturados nas camadas superiores confinadas, permitindo a troca de fluidos entre água subterrânea e o mar.

A descarga de águas subterrâneas (SGD) foi negligenciada cientificamente durante muitos anos por causa da dificuldade inerente a sua estimativa e a percepção de que este processo apresentava pouca importância. Contudo, nos últimos anos reconheceu-se que em alguns cenários a descarga de águas subterrâneas no mar pode ser volumétrica, ecológica e quimicamente importante para os balanços de massa (UNESCO, 2004; Burnett et al., 2006).

Considerando-se que o fluxo de vários constituintes importantes do ponto de vista biogeoquímico podem ser suportados pela SGD na zona costeira, o comitê cientifico em 
pesquisas oceânicas constituiu dois grupos de trabalho para examinar este tema emergente. O grupo de trabalho SCOR WG-112 "Magnitude da descarga de água subterrânea e sua influência em processos oceanográficos costeiros" foi estabelecido em 1997 para definir com maior precisão como a descarga de águas subterrâneas influencia processos químicos e biológicos na zona costeira (Burnett, 1999). O grupo de trabalho SCOR WG-114 "Transporte e reação em sedimentos marinhos permeáveis" foi estabelecido em 1999 para investigar a importância do fluido que percola através de sedimentos permeáveis para os ciclos biogeoquímicos locais e globais e a sua influência em ambientes circunvizinhos (Broudraux et al., 2001).

O conhecimento histórico a respeito da descarga de águas subterrâneas no mar existe há vários séculos. De acordo com Kohout (UNESCO, 2004), o geógrafo romano, Strabo, que viveu de 63 a.C. a 21 d.C, mencionou a existência de uma fonte submarina à 2,5 milhas além da praia de Latakia, Síria perto da Ilha de Aradus no Mediterrâneo. A água desta fonte foi coletada por um barco, utilizando-se um funil e um pote de couro, e transportada à cidade como uma fonte da água doce. Outros relatos históricos versam sobre vendedores da água em Barém que coletavam a água potável destas fontes submarinas longe da praia em navios para o seu respectivo uso em terra (Williams, 1946). Cidadãos etruscos usaram estas fontes costeiras em banhos termais (século II d.C), além de outras fontes submarinas localizadas ao longo do Mar Negro (Plínio 1, Século I d.C).

Embora existam fatos históricos evidenciando a ocorrência da descarga direta de águas subterrâneas no mar há muito tempo, sempre houve a carência de conhecimentos relacionados ao fenômeno. Do ponto de vista contemporâneo, com a crescente escassez das reservas de água doce em todo o mundo, surgiu a necessidade de se identificar e a manter prováveis reservas subterrâneas potáveis, tarefa essa desempenhada pelos hidrogeólogos. $\mathrm{Na}$ região da praia, o interesse principal dos trabalhos realizados no âmbito da hidrogeologia enfocou o processo de intrusão da água salgada no continente, mapeando-se a interface água salgada - água doce nestes aqüíferos costeiros.

A água subterrânea está constantemente em movimento e deságua no mar em resposta à infiltração da água das chuvas, ou da recarga das águas de superfície. Esta água eventualmente alcança o oceano, indiretamente através do fluxo fluvial ou diretamente na forma de SGD. O fluxo geralmente é determinado pela elevação do aqüífero no continente, 
conhecido como potencial hidráulico. O potencial hidráulico também pode influenciar o movimento da água na porção submersa do aqǘfero costa afora.

O movimento subterrâneo da água em aqüíferos costeiros apresenta duas componentes principais. A primeira corresponde a SGD e a segunda à intrusão de água do mar nos aqüíferos costeiros. Quando o potencial hidráulico do continente em direção ao oceano é grande, a SGD pode limitar a intrusão de água salgada nos aqüíferos costeiros, e deste modo, sua natureza pode contribuir para a qualidade das reservas de água potável próximo da costa. A diminuição da SGD causada pelo bombeamento excessivo de aqüíferos costeiros, por exemplo, pode aumentar o processo inverso de intrusão de água do mar.

Em áreas onde o escoamento superficial é pequeno ou variável, a SGD pode constituir o principal componente de água doce para a zona costeira. A descarga de água doce através do assoalho oceânico pode ser considerada um desperdício, especialmente em regiões áridas. Nestas áreas, a detecção da SGD pode indicar fontes alternativas de água doce para usos diversos. Pelo fato da água subterrânea conter tipicamente altas concentrações de sólidos dissolvidos quando comparada com a maior parte das águas superficiais terrestres, a SGD muitas vezes contribui aumentar para o fluxo de constituintes dissolvidos observados na região costeira (Burnett et al., 2006).

A maioria dos elementos químicos é transportada do continente para a zona costeira passando por uma "faixa quimicamente reativa" onde a mudança de parâmetros como a salinidade pode aumentar a dissolução de vários constituintes normalmente ligados/adsorvidos aos materiais particulados em suspensão ou sólidos do aqüífero. A maior parte das reações biogeoquímicas que afetam os estoques de carbono, nitrogênio e fósforo, ocorrem na região costeira aonde a SGD é tipicamente mais importante (Burnett et al., 2006).

Definimos a descarga de águas subterrâneas (SGD) como todo e qualquer fluxo de água em margens continentais do fundo do mar para o oceano, independentemente da composição do fluído ou força direcionadora (UNESCO, 2004). Assim, a composição da SGD pode variar de caso para caso, podendo ser, água doce descarregando no fundo do oceano, água do mar recirculada ou ainda uma combinação das duas. 
Alguns dos problemas ambientais mais sérios que impactam sistemas costeiros surgem onde a SGD está carregando poluentes e nutrientes, especialmente nitrogênio, do continente para águas costeiras com padrões de circulação restritos. Os fluxos de nutrientes via SGD tem sido a causa de eutrofização de pequenas lagoas costeiras. Além disso, devido às diferenças nas respectivas densidades, o componente doce da SGD pode influenciar a recirculação da água salgada, afetando a qualidade da água costeira e o fornecimento de nutrientes para as comunidades bentônicas existentes nesta região.

Os principais efeitos ambientais resultantes da SGD são o aumento do fornecimento dos constituintes dissolvidos para a zona costeira e a redução da salinidade das águas, que podem acarretar ocorrência do florescimento de algas em algumas áreas. Em outras regiões, as infiltrações de baixa salinidade podem gerar a formação de habitats localizados no assoalho oceânico, especialmente para os estoques de peixes bentônicos. A SGD também pode ocasionar mudanças na morfologia e nos substratos que servem como microhabitats. As infiltrações de grandes proporções podem desestabilizar sedimentos no assoalho oceânico ou na linha de costa. Quando a SGD flui através dos sedimentos com alto teor de compostos orgânicos, o processo pode acelerar a liberação de metano na sua superfície. Este processo contribui para a formação de gases do efeito estufa, aumentando as conseqüências do aquecimento global.

A composição química dos fluxos de SGD são comumente modificados durante o processo de percolação por meio do aqüífero e dos sedimentos. Os fluxos de nutrientes, radioisótopos, de elementos-traço e elementos menores da água, podem assumir assinaturas distintas mesmo na ausência de contaminação antrópica reconhecível. Como as águas costeiras são freqüentemente contaminadas com detritos, fertilizantes, substâncias patogênicas, pesticidas e resíduos industriais, a SGD pode vir a representar uma via para a difusão da poluição no oceano. Os fluxos de contaminantes e seus respectivos impactos potenciais na ecologia costeira são as razões-chave que levam aos gestores ambientais a considerarem a SGD no planejamento costeiro.

\subsection{Influência de forças continentais e marinhas que contribuem para os fluxos de descarga de águas subterrâneas e materiais na interface continente-oceano}


Várias forças de origem continentais e marinhas podem influenciar os fluxos dos fluidos subterrâneos na zona costeira. Os gradientes hidráulicos no continente podem ocasionar a descarga de água subterrânea na região costeira e podem contribuir para os fluxos de constituintes provenientes de aqüíferos confinados na região da plataforma. Os processos marinhos, tais como a variação das marés e os gradientes de pressão, gerados pelas correntes, podem induzir o fluxo de fluidos intersticiais em qualquer região da plataforma, aonde os sedimentos permeáveis estiverem presentes (FIG.3). As forças continentais e marinhas sobrepõem-se espacialmente e a advecção do fluido medido através dos sedimentos costeiros pode ser um resultado de forças compostas (UNESCO, 2004).

Dependendo da litologia dos aqüíferos costeiros, a SGD pode ser caracterizada geralmente por fluxos volumetricamente pequenos, que tornam a sua detecção e quantificação difíceis. Entretanto, uma vez que estes fluxos ocorrem ao longo de áreas muito extensas, o fluxo total pode ser extrapolado em uma grande área e pode ser significativo para os balanços de massa e a produtividade primária da região.

Os fluidos derivados do continente, compostos tanto por água doce quanto de mar recirculada, irão reagir com os elementos presentes nos sedimentos e sólidos dos aquíferos. Estas reações podem contribuir para o aumento substancial dos fluxos de nutrientes, do carbono, e de elementos-traços nestes fluidos. Desta maneira, a SGD pode ser uma fonte de constituintes importantes do ponto de vista biogeoquímico para a zona costeira. Isto pode resultar em poluição difusa em locais aonde existem águas subterrâneas contaminadas. 


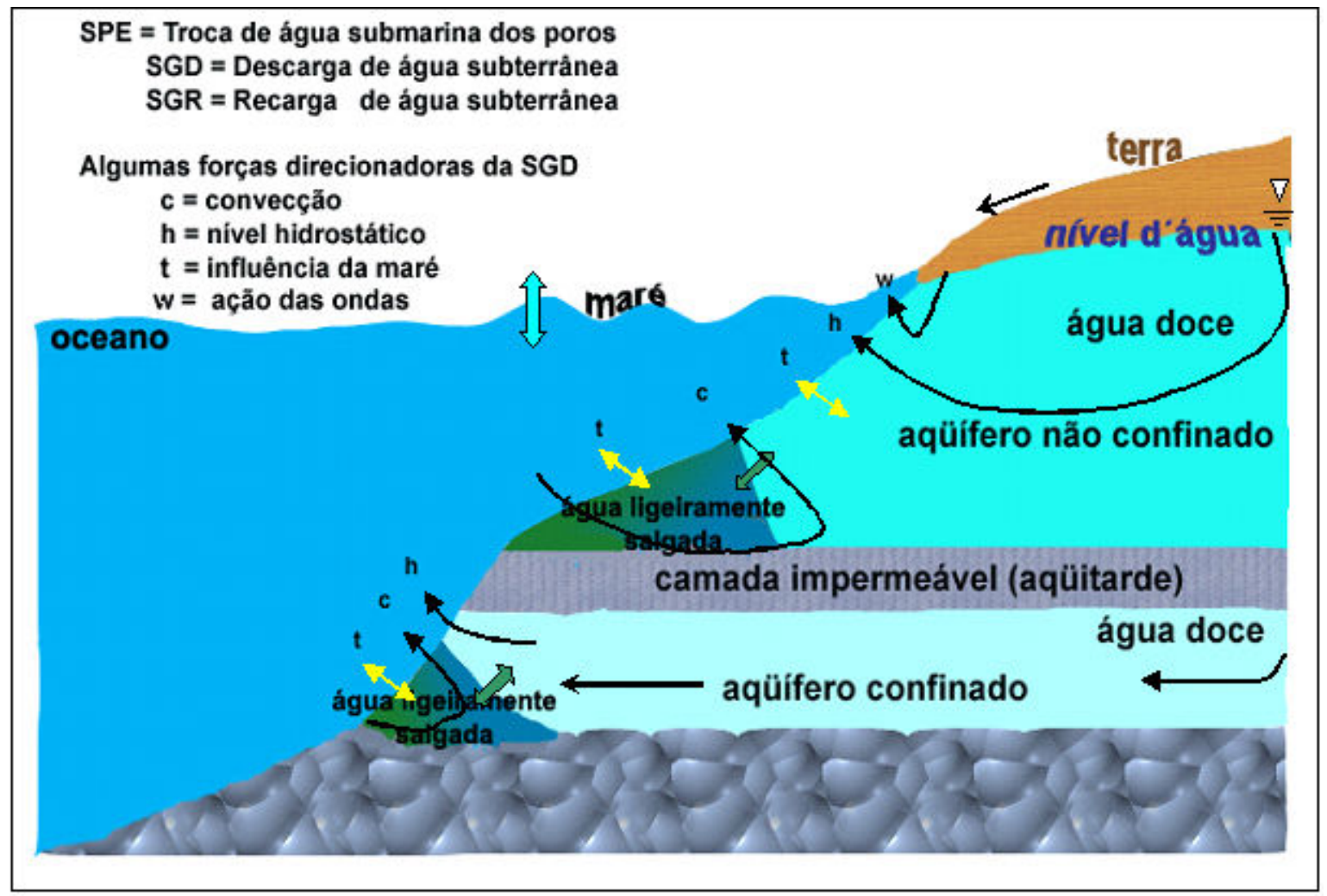

FIGURA 3 - Diagrama ilustrando a troca de fluídos (sem escala) dos processos associados com a recarga e descarga de fontes subterrâneas para a região costeira. As setas indicam o movimento dos fluidos (Sousa, 2008).

Ao nível global, a descarga de águas subterrâneas foi estimada como um pequeno percentual do fluxo total de água doce para os oceanos. Uma estimativa recente sugere um valor de $2.400 \mathrm{~km}^{3}$ de água doce descarregada por ano, o que corresponde a cerca de $6 \%$ da descarga anual dos rios (Burnett et al., 2006). Desse total, $1.500 \mathrm{~km}^{3}$ por ano derivam dos continentes e $900 \mathrm{~km}^{3}$ por ano tem origem em regiões insulares.

\subsection{Metodologias utilizadas na estimativa da descarga de águas subterrâneas}

As metodologias atualmente disponíveis para se estimar a descarga de águas subterrâneas em ambientes marinhos costeiros são fundamentadas em:

a) modelagem, incluindo cálculos simples dos fluxos de águas envolvidos no balanço hidrológico (Buddemeier, 1996);

b) medidas diretas dos fluxos in situ, restritas ao uso de câmaras bentônicas, também denominadas medidores manuais de taxas de infiltração, referenciados na literatura como medidores manuais do tipo "Lee" ou "seepagemeters" (Lee, 1977); 
c) medidas indiretas que podem ser conduzidas pelo mapeamento geofísico da resistividade/ condutividade e/ou transmissão de calor (Stieglitz et al., 2008);

d) uso de traçadores, incluindo espécies naturais, dentre os quais pode se citar o ${ }^{222} \mathrm{Rn}$, ${ }^{226} \mathrm{Ra}, \mathrm{CH}_{4}$, ou o uso de traçadores artificiais, como por exemplo, o $\mathrm{SF}_{6}$ (Cable et al. 1996; Corbett et al., 2000; Moore, 1996; Moore \& Shaw, 1998; Moore, 1999; Rama \& Moore, 1996; Burnett et al., 2006; Burnett et al., 2008; Moore \& Oliveira, 2008).

Os radionuclídeos naturais das séries do ${ }^{238} \mathrm{U}$ e do ${ }^{232} \mathrm{Th}$ tem sido utilizados em larga escala e com excelentes resultados para se estimar a SGD (Cable et al., 1996; Corbett et al., 2000; Moore, 1996; Moore \& Shaw, 1998; Moore, 1999; Rama \& Moore, 1996; Burnett et al., 2006; Burnett et al., 2008; Moore \& Oliveira, 2008). Traçadores geoquímicos naturais como o ${ }^{222} \mathrm{Rn}$ e o ${ }^{226} \mathrm{Ra}$, quando determinados em águas costeiras, são vantajosos em estimativas regionais da SGD, uma vez que os seus sinais representam valores integrados na coluna d'água. Estes radionuclídeos encontram-se enriquecidos na água subterrânea, podem ser detectados mesmo em concentrações muito baixas e são conservativos.

\subsection{O quarteto de isótopos naturais de Ra: elementos-chave para a compreensão dos processos estuarinos}

Os quatro isótopos naturais de Ra ocorrem naturalmente no meio ambiente como produtos de decaimento das séries naturais do ${ }^{238} \mathrm{U}$ e do ${ }^{232} \mathrm{Th}$. O Ra atinge o oceano toda vez que águas continentais em contato com estes elementos presentes em sedimentos dos rios, partículas em suspensão e/ou sólidos dos aqüíferos alcançam a interface água-doce/ água salgada. Quando o Ra ligado ao material particulado em suspensão na água doce encontra a água salgada, ele é dessorvido preferencialmente por troca-iônica com cátions sódio, cálcio e magnésio. Como resultado desse processo, existe um grande aporte de Ra de pântanos salinos, dos manguezais, dos estuários e da descarga de águas subterrâneas para o mar (Moore, 1996; Rama \& Moore, 1996; Moore \& Shaw, 1998). Estas fontes tornam o Ra um isótopo traçador de grande aplicabilidade em estudos de circulação de massas d'água na plataforma.

Os isótopos de Ra também estão presentes na água do mar, sendo produzidos continuamente na coluna d'água por difusão molecular dos sedimentos. Devido a sua meia- 
vida física muito mais longa que as dos demais isótopos, somente o ${ }^{226} \mathrm{Ra}$ pode ser encontrado em atividades substanciais no oceano (Broecker et al., 1967; Moore, 1969; Kauffman et al., 1973; Moore, 1976). Os outros três isótopos são menos abundantes devido tanto ao decaimento radioativo à curto prazo quanto ao fato dos elementos partículo-reativos que os originam (tório, protactínio e actínio) serem removidos da coluna d'água por processos de arraste. Enquanto o ${ }^{226} \mathrm{Ra}$ está presente na água do mar em pequenas quantidades, os isótopos de meias-vidas curtas não-suportados podem estar ausentes após a quebra da plataforma.

Os isótopos ${ }^{226} \mathrm{Ra}$ e o ${ }^{228} \mathrm{Ra}$ são os radionuclídeos mais importantes presentes em águas subterrâneas. Embora eles constituam o mesmo elemento, seu comportamento nos sistemas rocha-água pode ser bastante diferente. A primeira diferença a ser notada é que estes radionuclídeos pertencem a séries de decaimento radioativas naturais distintas. $\mathrm{O}$ ${ }^{226} \mathrm{Ra}$ é o quinto membro da série do ${ }^{238} \mathrm{U}$ e decai por emissão alfa. Devido ao fato do $\mathrm{U}$ formar complexos solúveis em soluções oxidantes, particularmente com carbonatos e fosfatos, ele pode ser transportado com maior facilidade pela água subterrânea. Em condições redutoras, o U precipita a partir da água subterrânea e se concentra em depósitos minerais secundários. Assim, as concentrações de ${ }^{226} \mathrm{Ra}$ em águas subterrâneas podem variar amplamente e podem ser maiores na proximidade de locais aonde há enriquecimento em urânio.

Elsinger \& Moore (1980) observaram em seus trabalhos que as atividades de ${ }^{226} \mathrm{Ra}$ no Baía Winyah na Carolina do Sul, eram consideravelmente maiores durante os períodos de vazões baixas e médias do Rio Pee Dee, do que durante o período de grande vazão deste rio. Estes autores postularam que o aumento do gradiente de salinidade rio acima, durante períodos de baixa descarga, liberava o ${ }^{226} \mathrm{Ra}$ presente nos sedimentos e do material em suspensão. Este estudo também demonstrou que os sedimentos estuarinos encontravam-se aproximadamente $30 \%$ deficientes nas atividades de ${ }^{226} \mathrm{Ra}$ em relação ao ${ }^{230} \mathrm{Th}$.

$\mathrm{O}{ }^{228} \mathrm{Ra}$ é o segundo membro da série de decaimento do ${ }^{232} \mathrm{Th}$ e decai por emissão beta. O Th é extremamente insolúvel e não está sujeito à mobilização em águas subterrâneas. Como resultado, as concentrações de ${ }^{228} \mathrm{Ra}$ podem ser diretamente controladas pela distribuição do Th nos sólidos e minerais do aqüífero. Nos locais aonde não há enriquecimento secundário em $\mathrm{U}, \mathrm{o}{ }^{228} \mathrm{Ra}$ é geralmente o isótopo de rádio 
predominante em solução, devido principalmente à alta abundância natural do Th em relação ao U.

A razão de atividade dos isótopos ${ }^{223} \mathrm{Ra} /{ }^{224} \mathrm{Ra}$ pode ser regenerada rapidamente a partir do seu respectivo isótopo de Th depositado nos sedimentos. A razão de atividade de um isótopo de Ra de meia-vida curta em relação a um de meia-vida longa é esperada ser mais alta em águas aonde a ressuspensão dos sedimentos ocorreu recentemente do que naquelas nas quais o quarteto de isótopos foi introduzido por uma fonte de água que tenha tido tempo de residência suficientemente longo para permitir que todos os isótopos entrassem em equilíbrio, tal como ocorrem na água subterrânea (Moore, 1996). 


\section{CAPÍTULO 3 - ISÓTOPOS NATURAIS DE Ra COMO TRAÇADORES ISOTÓPICOS DE PROCESSOS NA INTERFACE CONTINENTE-OCEANO}

\subsection{O elemento Ra}

Apenas quatro isótopos naturais de Ra ocorrem naturalmente: ${ }^{223} \mathrm{Ra},{ }^{224} \mathrm{Ra},{ }^{226} \mathrm{Ra}$ e ${ }^{228} \mathrm{Ra}$. $\mathrm{O}{ }^{226} \mathrm{Ra}$ e o ${ }^{228} \mathrm{Ra}$ são os isótopos naturais de rádio mais abundantes e também são os mais radiotóxicos devido as suas meias-vidas relativamente longas (Williams \& Kirchmann, 1990). O elemento apresenta em solução apenas o estado de oxidação (+2) e devido ao seu caráter altamente básico, este íon bivalente não é facilmente complexado. A maior parte dos compostos de rádio são sais brancos quando recentemente preparados, tomando-se amarelados e finalmente acinzentados com o tempo devido a autodecomposição ocasionada pela emissão de partículas-alfa.

O Ra pode vir a formar vários compostos insolúveis. O sulfato de rádio é o mais insolúvel dos sulfatos dos alcalino-terrosos e provavelmente o sal de Ra mais insolúvel que se conhece. Sua solubilidade é de $2,1 \times 10^{-4} \mathrm{~g} / 100 \mathrm{~g}$ de água . Por este motivo, a precipitação em forma de sulfato é a mais comum para se recuperar o Ra, particularmente com a adição de um carregador de Ba. A precipitação é feita pela adição de ácido sulfúrico diluído à solução que contém o Ra.

$\mathrm{O} \mathrm{BaSO}_{4}$ é um carregador excelente para o Ra, adsorvendo-o exatamente quando os cristais de sulfato de bário são formados no processo de precipitação. Imediatamente, uma parte do Ra adsorvido pode ser removida por lavagem dos cristais, mais decorrido um curto intervalo de tempo, o Ra é definitivamente incorporado ao retículo cristalino. A partir deste instante, a migração do Ra dentro do retículo cristalino do sulfato de bário continua lentamente enquanto os cristais isomorfos mistos são formados.

Muitos dos compostos de Ra são mais insolúveis que os correspondentes sais de Ba e podem se concentrar em sólidos formados por misturas Ba-Ra. Uma exceção à regra é o $\mathrm{RaCO}_{3}$, que é mais solúvel que o respectivo $\mathrm{BaCO}_{3}$ e concentra-se na fração solúvel quando presente numa mistura de carbonatos de bário e rádio. 
Devido a sua grande insolubilidade, o $\mathrm{RaSO}_{4}$ é biologicamente menos perigoso do que a maior parte dos compostos de Ra. Ele é amplamente utilizado na preparação de padrões de Ra.

$\mathrm{O} \mathrm{Ra}(\mathrm{OH})_{2}$ é o mais solúvel dos hidróxidos dos metais alcalino-terrosos e mais básico que o $\mathrm{Ba}(\mathrm{OH})_{2}$. Ele é mais solúvel que os respectivos hidróxidos de Th e de Ac e pode ser separado destes elementos por precipitação $\mathrm{NH}_{4} \mathrm{OH}$.

O Ra co-precipita com a maioria dos compostos de $\mathrm{Ba}$, o que ocorre em menor extensão com os compostos de $\mathrm{Sr}$ e de $\mathrm{Pb}$.

A elevada estabilidade do complexo de Ba com EDTA tem sido utilizada para a separação fracionada de $\mathrm{Ba}$ e Ra por troca-iônica e por precipitação fracionada com $\mathrm{HCl}$ depois da dissolução da mistura dos sulfatos em solução de EDTA dissódico em meio amoniacal. O Ra, dentre os metais alcalino-terrosos, é o elemento que tem menor tendência a formar íons complexos.

\subsection{Distribuição dos isótopos de Ra no compartimento aquático}

As trocas complexas que ocorrem na região costeira e que incluem a transferência de elementos-traço e isótopos de águas superficiais e águas subterrâneas para o oceano afetam diretamente os ciclos biogeoquímicos globais. Os cientistas ambientais possuem poucas metodologias capazes de auxiliar a quantificação precisa dos fluxos envolvidos nestes processos, dentre as quais, ressalta-se a aplicação de radionuclídeos naturais como traçadores. Os isótopos naturais de $\mathrm{Ra}$ têm sido exaustivamente determinados nos compartimentos aquáticos com o intuito de aplicar seus respectivos gradientes de concentração e seus conseqüentes desequilíbrios isotópicos para quantificar a descarga de águas subterrâneas e processos de mistura que ocorrem na interface continente-oceano. A assinatura inconfundível dos quatros isótopos de $\mathrm{Ra}$ pode ser observada nas regiões estuarinas, zonas de mistura entre águas doces e salgadas, que pode muitas vezes ocorrer não apenas nos reservatórios superficiais, mas atingir os aqüíferos costeiros, ocasionando trocas químicas equivalentes no compartimento denominado "estuário subterrâneo".

$\mathrm{O}$ quarteto de isótopos de Ra possui meias-vidas físicas que correspondem bem com intervalo de tempo de duração de muitos processos costeiros. Como os isótopos de Ra 
são mobilizados no ambiente marinho em virtude do aumento da salinidade, os sedimentos costeiros constituem fontes contínuas destes isótopos para interface continente-oceano, em taxas definidas pelas suas respectivas constantes de decaimento. Determinando-se a concentração de atividade de Th nos sedimentos e o coeficiente de distribuição do Ra entre o sedimento e a água costeira, pode-se determinar os fluxos dos isótopos de Ra para o cenário em estudo. Considerando-se que as atividades de ${ }^{228} \mathrm{Ra}$ podem ser regeneradas muito mais rápido que o ${ }^{226} \mathrm{Ra}$, estuários nos quais valores das razões de atividade ${ }^{228} \mathrm{Ra} /{ }^{226} \mathrm{Ra}$ sejam elevadas devem apresentar intensas trocas químicas com sedimentos ou com fontes de água doce drenando no local. Da mesma forma, a remoção do U das águas estuarinas indica uma exposição substancial das águas salinas que circulam através dos sedimentos. Estas informações são úteis para elucidar a contribuição dos estuários nas trocas de elementos-traço e carbono que ocorrem na zona de mistura (Charette et al., 2005).

\subsubsection{Distribuições de Ra no oceano}

Devido as suas meias-vidas relativamente longas, o ${ }^{226} \mathrm{Ra}$ e ${ }^{228} \mathrm{Ra}$ podem ser encontrados em atividades facilmente detectáveis no oceano. Uma vez que as suas meiasvidas são da mesma ordem de grandeza que o tempo de mistura dos oceanos, atividades consideravelmente altas de ${ }^{226} \mathrm{Ra}$ podem ser observadas no Atlântico, com valores médios de cerca de $8 \mathrm{dpm} / 100 \mathrm{~L}$ ( aproximadamente $133 \mathrm{mBq} / 100 \mathrm{~L}$ ). A atividade média de ${ }^{228} \mathrm{Ra}$ no oceano Atlântico, aproximadamente 1,5 dpm/ 100 L (25 mBq/100 L), é um reflexo da sua meia-vida mais curta. As atividades médias destes isótopos no oceano podem ser subtraídas das atividades encontradas na região costeira para se estimar as atividades em excesso de ${ }^{226} \mathrm{Ra} \mathrm{e}^{228} \mathrm{Ra}$ em uma dada amostra (Moore, 1996).

Outra fonte dos isótopos de Ra para a coluna d'água do mar são os sedimentos marinhos, principalmente aqueles que contêm altas concentrações de Th e $U$ acumulados nas partículas depositadas. Areia e cascalhos, que são compostos principalmente de quartzo, possuem concentrações relativamente baixas dos isótopos de $\mathrm{U}$ e Th precursores, mas siltes finos e argilas, transportados em suspensão, podem contribuir para a presença de quantidades significantes dos isótopos de $\mathrm{Ra}$ nas águas de fundo, especialmente se o arraste de material particulado for elevado nas camadas de água superiores. Como a maior parte do Ra ligado à superfície do material particulado passará ao estado dissolvido na 
coluna d'água salgada, a difusão de Ra dos sedimentos depende da sua regeneração dos isótopos precursores após a deposição. Desta forma, este processo é em parte influenciado pelas meias-vidas físicas dos diferentes isótopos de Ra, que determinam quanto tempo é necessário para se atingir o equilíbrio radioativo com seus respectivos elementos precursores. Os isótopos de Ra de meias-vidas curtas entrarão em equilíbrio com os precursores de meias-vidas longas rapidamente. A atividade de ${ }^{228} \mathrm{Ra}$, por exemplo, é regenerada cerca de 280 vezes mais rápido que a atividade de ${ }^{226} \mathrm{Ra}$ (Krest et al. 1999).

\subsubsection{Distribuições de Ra nas águas superficiais}

A água superficial desempenha um papel vital no ciclo biogeoquímico de muitos elementos essenciais, bem como tóxicos, no sistema aquático e recebe Ra de uma variedade de fontes. A quantidade natural de isótopos de $\mathrm{Ra}$ nas águas correntes e reservatórios é determinada principalmente por sua quantidade na fonte de alimentação destes cursos d'água e pela lixiviação do Ra do solo, rochas e sedimentos.A radiação de fundo pode variar consideravelmente dependendo da concentração de U, Th e Ra presentes na litosfera local.

A migração do Ra na água de superfície ocorre pela combinação de vários processos naturais que são freqüentemente influenciados pelo homem. Dentre os processos mais importantes pode-se citar:

- processos de difusão e advecção;

- trocas na forma físico-química (especiação) do Ra na água de superfície, induzida pela composição química da água e/ou outras condições ambientais;

- adsorção do Ra dissolvido nos sólidos suspensos e sedimentos de fundo;

- co-precipitação do Ra com sólidos formados na água;

- sedimentação do Ra particulado e ressuspensão dos sedimentos de fundo;

- dissolução e dessorção do Ra dos sólidos suspensos e sedimentos de fundo;

- incorporação biológica e transporte.

O Ra liberado para a água de superfície é transportado na água e sofre várias transformações, podendo depositar e migrar para os sedimentos de fundo ou ser incorporado pelos organismos vivos, entrando assim, na cadeia alimentar. 
A difusão de $\mathrm{Ra}$ dos sedimentos pode aumentar as concentrações desse isótopo em amostras de águas costeiras, alcançando a superfície quando houver uma mistura vertical considerável, ressurgência na plataforma, passagem de correntes por planícies rasas ou ainda pela descarga de águas subterrâneas.

Torgersen et al. (1996) revelaram que enquanto em águas próximas da região de praia se observavam concentrações aumentadas de ${ }^{224} \mathrm{Ra}$, a água de fundo coletada no centro das enseadas estudadas se encontrava duas vezes mais enriquecida neste isótopo, possivelmente devido à presença de sedimentos com granulometria muito fina. Estes autores também observaram que em águas com concentrações aumentadas de oxigênio dissolvido, os óxidos de manganês poderiam precipitar na superfície dos sedimentos, aumentando a difusão do Ra para a coluna d'água, influenciando os fluxos relativos desse elemento. Li et al. (1979) observaram que nem sempre há uma correlação linear entre os isótopos de Ra e a salinidade na região estudada em Nova Iorque, como era previsto pois a principal fonte de isótopos de Ra para o sistema era de água doce. Isto pode ser um indicativo de um processo de mistura vertical, sendo a fonte aumentada de difusão dos isótopos de Ra dos sedimentos.

\subsubsection{Distribuições de Ra nas águas subterrâneas}

A presença de Ra nas águas subterrâneas proveniente de fontes naturais resulta da interação desta água com o solo, as rochas ou depósitos minerais com os quais ela se encontra em contato constante no aqüífero. A concentração de Ra na água subterrânea dependerá dos mecanismos de transferência e da quantidade de Ra na fonte, dos mecanismos que removam o Ra da água e dos processos mecânicos que mobilizam o Ra para além da fonte.

O Ra também pode ser incorporado indiretamente pela água subterrânea, como conseqüência de atividades humanas que visam explorar minerais contendo quantidades apreciáveis de U e Th, como parte do ciclo do combustível nuclear. Além disso, vários outros minerais de importância econômica podem apresentar teores consideráveis de radionuclídeos naturais, tal como minerais ricos em fosfato (apatita), em cobre, em ouro e no carvão, dentre muitos outros. Isto é devido à presença de $\mathrm{U}$ e seus produtos de decaimento de meia-vida longa nestes minerais, como o ${ }^{226} \mathrm{Ra}$, o ${ }^{230} \mathrm{Th}$, o ${ }^{210} \mathrm{~Pb}$ e o ${ }^{210} \mathrm{Po}$. 
Os processos de exploração e mineração destes minerais com o objetivo de separar o elemento de interesse econômico contribuem para o aumento das concentrações de rádio no meio ambiente, acima dos níveis considerados normais (Oliveira, 1998).

Um estudo realizado por Kaufmann (1977) na Flórida demonstrou que as concentrações de ${ }^{226} \mathrm{Ra}$ em águas subterrâneas aumentam proporcionalmente à salinidade, que por sua vez varia com a profundidade e o regime hidrológico do poço dentro do aqüífero. As concentrações de ${ }^{226} \mathrm{Ra}$ nas águas subterrâneas da região central da Flórida variaram desde não-detectável até $2.810 \mathrm{mBq} / \mathrm{L}$.

\subsection{Distribuições de Ra em águas estuarinas}

Os estuários são definidos como regiões de transição ecológica que desempenham importante função de ligação e troca genéticas entre os ecossistemas terrestres e marinhos, fato que o classifica como ambiente complexo, diversificado e de extrema importância para a sustentação da vida do mar. As concentrações de nutrientes aumentadas e condições ambientais favoráveis, como os gradientes térmico e salino, transformaram os ambientes estuarinos num dos principais focos de atenção no que diz respeito à conservação ambiental e à manutenção de sua biodiversidade (Carvalho \& Rizzo, 1994).

Além disso, os estuários são sistemas muito dinâmicos em virtude das mudanças hidrológicas e hidroquímicas a que estão sujeitos e da rapidez de interação entre as fases dissolvidas e particuladas da matéria, característica desses ambientes. Essas transformações e mudanças hidroquímicas caracterizam os sistemas como redentores e exportadores de matéria, tanto na fase particulada como na fase dissolvida, levando à interferência no equilíbrio dos ciclos biogeoquímicos no interior dos sistemas e na plataforma adjacente.

O estudo da distribuição natural do Ra em vários compartimentos do ecossistema tem sido de grande importância para a compreensão de seu comportamento ambiental. Neste contexto, durante os últimos anos, o rádio tem sido quantificado em várias matrizes ambientais como em rochas, no solo, na água continental e nos oceanos, em alimentos, em animais e plantas aquáticas, em animais e plantas terrestres e no homem. 
A água de rio e a água do mar diferem amplamente em composição. A água de rio tem baixa força iônica e é rica em partículas em suspensão. $O$ estuário é a zona por meio da qual a água de rio encontra a água do mar. As reações químicas em estuários ocorrem principalmente em resposta às interações das cargas particulares nos rios com a alta força iônica das águas do mar e da produtividade biológica estimulada pelos nutrientes fornecidos pelos rios. Alguns elementos químicos são seqüestrados em estuários, outros são liberados pelas partículas, ou também, simplesmente diluídos com água dos rios (Moore, 1990).

Os processos físicos e químicos que ocorrem em estuários aumentam o fonecimento dos isótopos de Ra para o oceano pelos rios (Elsinger \& Moore, 1980; Elsinger \& Moore, 1983; Li et al, 1977; Li \& Chan, 1979; Moore, 1981; Santschi et al, 1979). Em estuários, podem ser identificadas três funções-fonte:

$\checkmark$ Ra dissolvido, que é a quantidade de rádio que está em solução na água de rio;

$\checkmark$ O Ra adsorvido nas partículas fluviais, que é dessorvido quando a força iônica da água aumenta. Este aumento na força iônica que ocasiona a dessorção do Ra pode ser uma conseqüência do movimento das partículas na água salgada, ou o movimento da água salgada nos sedimentos fluviais recentemente depositados durante condições de baixa descarga;

$\checkmark$ O Ra gerado pelo decaimento do Th em sedimentos estuarinos que escapa por difusão ou durante a mistura física ou pela ação biológica dos escavadores dos sedimentos (bioturbação) e a água intersticial.

Perfis de isótopos de $\mathrm{Ra}$ em estuários demonstram que nestes sistemas os processos físicos e químicos resultam em aumento não-conservativo da atividade de cada isótopo de Ra. A dessorção parece ser o mecanismo primário de enriquecimento de ${ }^{226} \mathrm{Ra}$ em estuários (Elsinger \& Moore, 1980; Elsinger \& Moore, 1983; Li et al., 1977; Li \& Chan, 1979). Para o ${ }^{228} \mathrm{Ra}$ e o ${ }^{224} \mathrm{Ra}$, é também necessário considerar o tempo de residência da água no estuário. Se ele for uma fração significante da vida média do isótopo, o Ra gerado nos sedimentos de fundo pode escapar e aumentar as atividades dissolvidas na água de superfície. 
Os isótopos bivalentes do cátion Ra estão ligados às partículas no solo e rochas na água doce. Eles são facilmente dessorvidos via troca-iônica na presença de soluções de força iônica mais alta (Webster et al., 1994; Yang et al., 2002). Conseqüentemente, em aqüíferos costeiros, onde a água do mar com alta força iônica, mistura-se e interage com a água doce e rochas do aqüífero, são observadas águas enriquecidas em Ra (Moore, 2003).

Segundo Moore (1987) a contribuição dos sedimentos como fontes potenciais de ${ }^{226} \mathrm{Ra}$ e ${ }^{228} \mathrm{Ra}$ em águas costeiras ocorre predominantemente nas regiões de plataforma interna, pois na plataforma externa os sedimentos apresentam pouco potencial de liberação de Ra. Levy (1985) apresentou evidências de que o ${ }^{224} \mathrm{Ra}$ poder produzido na plataforma a partir do ${ }^{228} \mathrm{Th}$. Como o ${ }^{228} \mathrm{Th}$ é produzido pelo decaimento do ${ }^{228} \mathrm{Ra}$ no sistema, ele é rapidamente removido para o sedimento, e por sua vez, produz e libera o ${ }^{224} \mathrm{Ra}$.

Quando se utilizam os isótopos de Ra como traçadores de massas d'água costeiras, é necessário considerar ainda as concentrações de Ra em excesso. No caso do ${ }^{224} \mathrm{Ra}$, a atividade em excesso pode ser determinada facilmente calculando-se a atividade inicial e fazendo-se a medida subseqüente dos filhos do ${ }^{228} \mathrm{Th}$, que também é adsorvido em fibras de acrílico impregnadas com dióxido de manganês, utilizadas na coleta e pré-concentração destes elementos. $\mathrm{O}{ }^{224} \mathrm{Ra}$ suportado pelo decaimento do ${ }^{228} \mathrm{Th}$ poderá, então, ser subtraído da medida inicial para se obter a atividade de ${ }^{224} \mathrm{Ra}$ em excesso (FIG. 4). Um procedimento similar pode ser utilizado para se obter a atividade de ${ }^{223} \mathrm{Ra}$ em excesso que não é suportada pelo ${ }^{227}$ Ac dissolvido. 


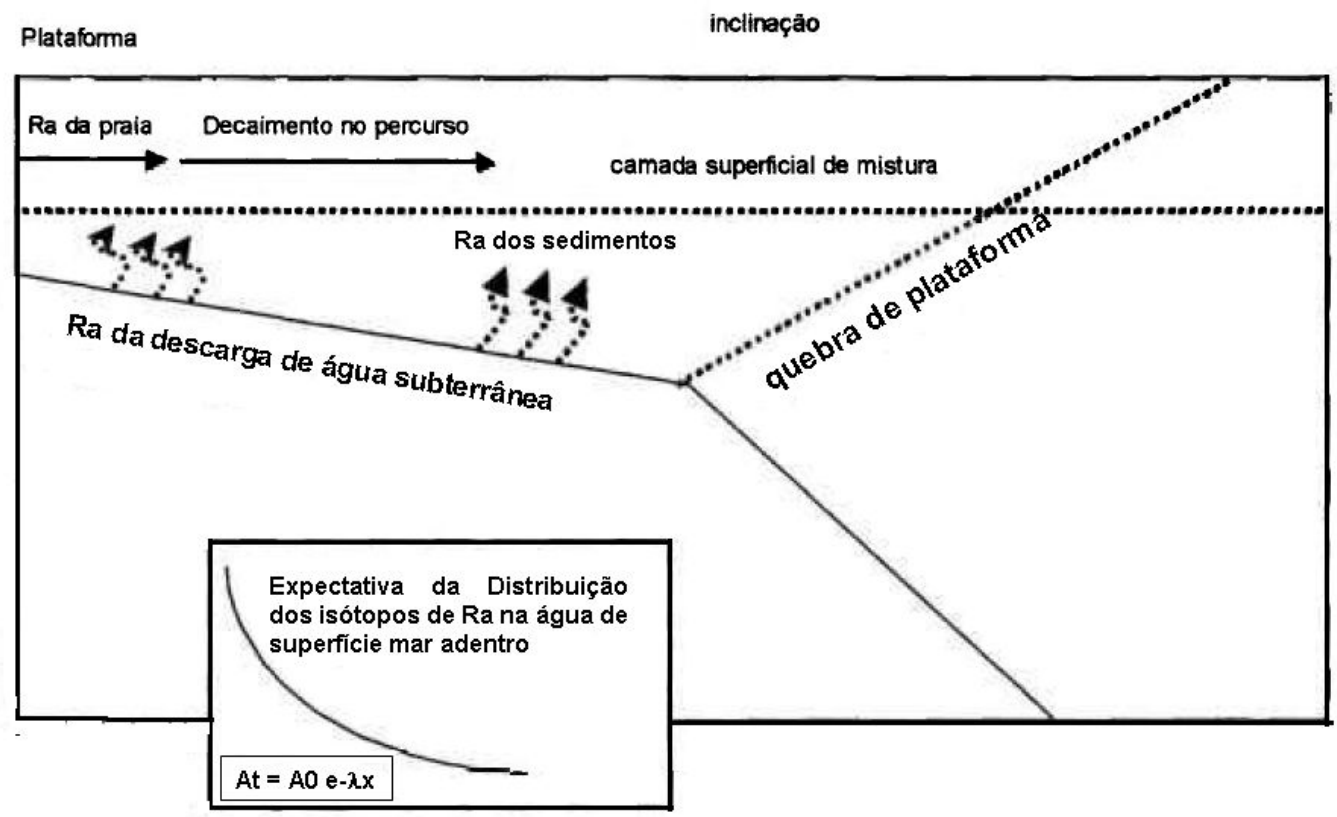

FIGURA 4 - Distribuição simplificada das fontes de Ra para a água do mar, incluindo sedimentos e descarga de água subterrânea.

A água do oceano, entretanto, tem atividades constantes ou muito baixas de Ra. Portanto, o Ra em excesso (acima das atividades normalmente encontradas na água do oceano) indica uma fonte costeira que, em muitos casos, é devida a SGD. Os isótopos de Ra são excelentes traçadores para documentar a SGD e processos de mistura em sistemas costeiros, pois fornecem uma forma eficaz de se diferenciar atividades entre as fontes (por exemplo, águas salinas continentais de águas salgadas do oceano). Estes isótopos se comportam conservativamente depois que deixam o aqüífero (considerando o decaimento radioativo).

A utilização dos isótopos de Ra tem vantagens sobre outras técnicas empregadas para se quantificar os fluxos relacionados a SGD, uma vez que permite a integração espacial e temporal sobre a vida-média dos radionuclídeos (Moore, 2003), e as escalas de tempo diferentes do decaimento são úteis como rastreadores de mistura. De fato, os isótopos de Ra são extensivamente utilizados para determinar a descarga de águas doces, nutrientes (Cable et al., 1996; Kelly \& Moran, 2002; Krest et al., 2000) e outros constituintes dissolvidos para o oceano costeiro (Shaw et al., 1998). 
As propriedades de mistura da água em um estuário são controladas pela força iônica, pH, composição química, floculação, remoção de organismos e adsorção ou dessorção de constituintes, os quais podem influenciar fortemente o fluxo de espécies químicas para o oceano (Lee, 2005).

Em estuários, vários trabalhos apontam para a dessorção de Ra do material particulado e de sedimentos. A dessorção do Ra neste sistema é atribuída ao aumento da força iônica da água ( $\mathrm{Li}$ et al., 1979). Medidas realizadas no Rio Hudson, demonstraram que as atividades de ${ }^{226} \mathrm{Ra}$ no estuário são freqüentemente maiores do que as atividades observadas nos rios e no oceano (Li et al., 1977). Eles postularam que a dessorção do Ra ligado à superfície dos sedimentos ocorre quando os sedimentos entram em águas estuarinas de alta força iônica. Medidas experimentais da liberação de Ra dos sedimentos originados dos rios comprovaram que este mecanismo foi importante no fornecimento de Ra para o estuário, pois a mistura entre água do rio e água do mar em um estuário está associada com vários processos químicos, físicos e biológicos.

Dessa forma as águas estuarinas apresentam atividade dissolvida dos quatro isótopos naturais de Ra, provenientes de processos de dessorção da superfície de partículas, bem como da contribuição de águas subterrâneas submarinas enriquecidas com esse radionuclídeo (FIG. 5).

Segundo Moore (1980), as águas de estuários apresentam maiores concentrações de urânio com relação à água doce. Para este aumento é atribuído à liberação do urânio do material particulado sedimentado; a liberação pode ser causada ou pela redução do Fe, que dissolve as partículas de óxidos nos quais o U está ligado, ou pela alta alcalinidade da água, que induz a dessorção. O U passa para a coluna d'água com a complexação com íons carbonato. $\mathrm{O}{ }^{228} \mathrm{Th}$ produzido por decaimento do ${ }^{228} \mathrm{Ra}$, nos estuários, é rapidamente removido da coluna d'água, pois o mesmo tem forte tendência de adsorção em material particulado. 


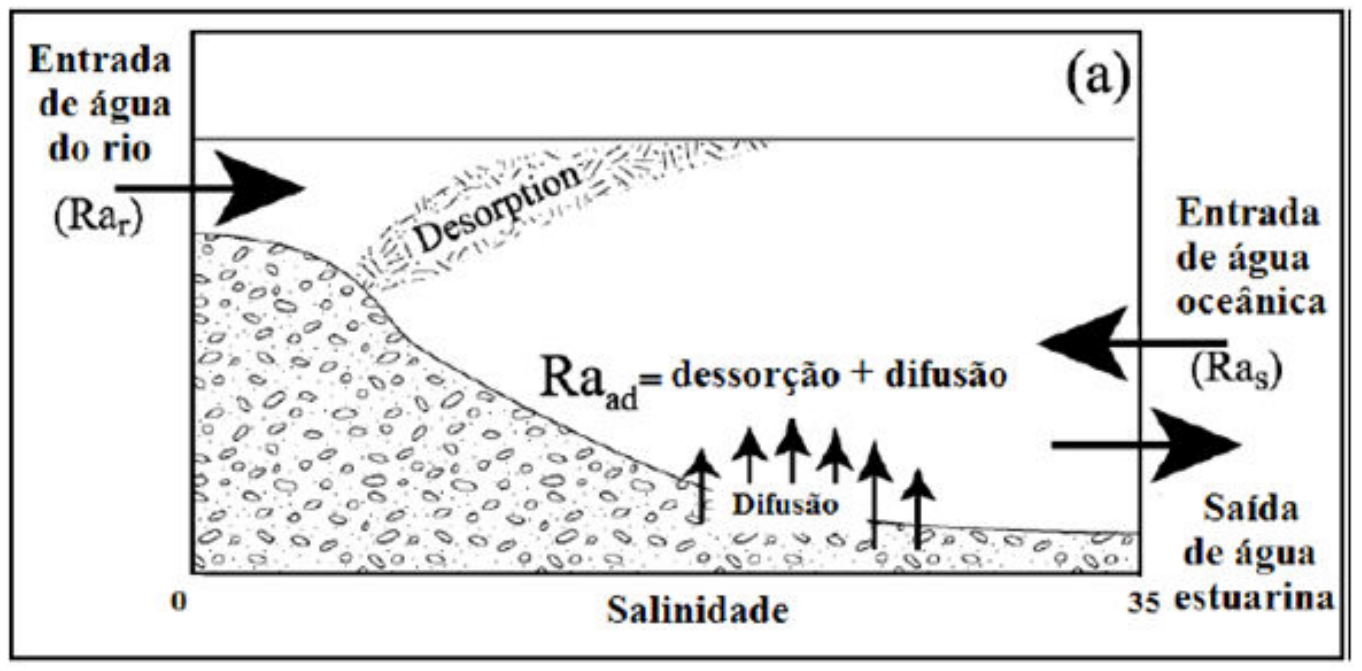

FIGURA 5 - Distribuição dos isótopos de Ra no estuário como uma função da salinidade. (a) Isótopos de $\mathrm{Ra}$ em um estuário $\left(\mathrm{Ra}_{\mathrm{e}}\right)$, em água de rios $\left(\mathrm{Ra}_{\mathrm{r}}\right)$, águas do oceano $\left(\mathrm{Ra}_{\mathrm{o}}\right)$, e processos adicionais $\left(\mathrm{Ra}_{\mathrm{ad}}\right)$, como dessorção de partículas e difusão de sedimentos. (Souza, 2008)

No Brasil, os estuários são regiões ricas em nutrientes, locais com grande potencial para produção primária que enriquecem as águas costeiras, em sua maioria oligotróficas. Em regiões sob influência de águas tropicais naturalmente pobres em suas características tróficas, o estudo da dinâmica dos nutrientes em sua forma dissolvida somado ao conhecimento dos mecanismos de troca e transferência dos mesmos na interface continente-oceano é vital à produção marinha.

\subsection{Estimativa dos fluxos superficiais de Ra}

Li \& Chan (1979) desenvolveram um modelo de balanço de massas que permitiu estimar os fluxos dissolvidos e a dessorção de Ra no estuário do Rio Hudson. Assumindo a hipótese de estado estacionário e desprezando as eventuais alterações no volume de água pelos fenômenos de evaporação e precipitação, e formulando-se três equações para a conservação do volume d'água (Q), salinidade (S) e concentração de um elemento conservativo $(\mathrm{C})$, neste caso ${ }^{226} \mathrm{Ra}$, a seguinte relação foi derivada: 


$$
C_{R}+\frac{I_{C}}{Q_{R}}=\left(\frac{S_{0}}{S_{0}-S_{E}}\right) C_{E}-\left(\frac{S_{E}}{S_{0}-S_{E}}\right) C_{0}
$$

Onde:

$I_{C}=$ fluxo total de um elemento conservativo por dessorção e suprimento dos sedimentos do fundo $\left(\mathrm{g} / \mathrm{m}^{3}\right.$ e/ou $\left.\mathrm{mBq} / \mathrm{m}^{3}\right)$.

Os subscritos $R, E$, $O$ se referem ao rio, o estuário e oceano, respectivamente.

\subsection{Aplicação dos isótopos naturais de Ra como traçadores da descarga de águas subterrâneas em áreas estuarinas}

O fluxo de ${ }^{226} \mathrm{Ra}$ em excesso para um estuário ou enseada pode ser calculado pela seguinte expressão:

$F_{226 R a}=\left(\frac{{ }^{226} \text { Ra estuario } x \text { Vol. estuario }}{\text { tempo de mistura }}\right)-\left({ }^{226}\right.$ Ra rio $x$ Vazão rio $)-\left({ }^{226}\right.$ Ra sed.estuario $x$ Área estuario $)$

Onde:

$F^{226} R a=$ fluxo de ${ }^{226} \mathrm{Ra}$ em excesso para o estuário $(\mathrm{mBq} / \mathrm{d})$.

${ }^{226}$ Ra estuário $=$ concentração de ${ }^{226} \mathrm{Ra}$ na água do estuário $\left(\mathrm{mBq} / \mathrm{m}^{3}\right)$.

Vol. estuário $=$ volume do estuário $\left(\mathrm{m}^{3}\right)$.

tempo de mistura = tempo de mistura calculado a partir das concentrações de ${ }^{223} \mathrm{Ra},{ }^{224} \mathrm{Ra} \mathrm{e}$ ${ }^{228} \mathrm{Ra}(\mathrm{d})$.

${ }^{226}$ Ra rio $=$ concentração de ${ }^{226} \mathrm{Ra}$ na água do rio que deságua no estuário $\left(\mathrm{mBq} / \mathrm{m}^{3}\right)$.

Vazão do rio $=$ volume d'água descarregado pelo rio no estuário estudado $\left(\mathrm{m}^{3} / \mathrm{d}\right)$.

${ }^{226} \mathrm{Ra}$ sed. estuário = concentração de ${ }^{226} \mathrm{Ra}$ no sedimento de fundo coletado dentro do estuário $(\mathrm{mBq} / \mathrm{kg})$. 


\section{CAPÍTULO 4 - CARACTERIZAÇÃO DA ÁREA DE ESTUDO}

\subsection{Compartimentação do Litoral Sul do Estado de São Paulo}

Geologicamente, o litoral paulista é formado por planícies sedimentares de idade Cenozóica, com pequeno desenvolvimento da planície costeira, condicionados aos diversos estágios de flutuações do nível do mar. Essas planícies fazem o contato entre os terrenos cristalinos da Serra do Mar com as águas oceânicas e apresentam maiores extensões na região central e sul do litoral (IPT, 1979). São naturalmente frágeis por serem áreas sujeitas às inundações periódicas e apresentarem lençol freático pouco profundo. Intercalando as planícies, encontram-se afloramentos de rochas cristalinas que compõe os morros litorâneos e a escarpa da Serra do Mar formada pelo soerguimento de rochas cristalinas promovido por movimentos tectônicos ocorridos no período Pré-Cambriano, cuja drenagem apresenta padrão dendrítico, adaptada às direções estruturais.

A evolução Cenozóica do território paulista mostra claramente que seus eventos geológicos podem ser resumidos na formação do relevo e deposição de seqüências sedimentares que lhes são correlativas (IPT, 1979). Nas províncias costeiras, as formações Cenozóicas são ambientes característicos da interface continental-marinha, que impõem grande variação de áreas-fonte (IPT, 1981).

É no litoral sul do estado de São Paulo com aproximadamente 498 mil habitantes (IBGE, 2006), que se encontra o Rio Ribeira de Iguape, com uma largura entre 100 e 120 metros (Giatti, 2004) e uma vasta extensão que percorre uma boa parte da região do Vale do Ribeira. Essa região ocupa 10\% do território paulista, sendo dividido geograficamente, em três porções no Estado de São Paulo: a Baixada do Ribeira; a Sub-litorânea; e o Alto do Ribeira, onde esta última compreende os municípios de Iporanga, Apiaí e Ribeira (Diegues, 2007).

O sítio geológico do Vale do Ribeira é marcado por um exuberante patrimônio geomorfológico e espeleológico, com feições típicas, como carste poligonal, cones e canyons cársticos, vales fluviais profundos, escarpamentos rochosos com pórticos de 
cavernas, sistemas de drenagem subterrânea com grande variedade espeleomorfológica, e cavernas com sítios paleontológicos do Quaternário ( Karmann \& Ferrari, 2002).

A porção Sub-litorânea é composta pelos municípios de Iguape, Ilha Comprida e Cananéia, onde se encontra o Complexo estuarino-lagunar de Iguape, Cananéia e Paranaguá, área reconhecida pela Unesco como parte da Reserva da Biosfera, devido à sua importância enquanto meio ambiente natural.

O complexo Estuarino Lagunar de Iguape-Cananéia-Paranaguá está situado entre as latitudes de $24^{\circ} 40^{\prime} \mathrm{S}$ e $25^{\circ} 05^{\prime} \mathrm{S}$ e as longitudes de $47^{\circ} 25^{\prime} \mathrm{W}$ e $48^{\circ} 10^{\prime} \mathrm{W}$ (FIG. 6). O sistema é constituído de canais lagunares de maré e rios entre quatro grandes ilhas: Ilha do Cardoso, Ilha de Cananéia, Ilha Comprida e Ilha de Iguape. Os corpos d'água que delimitam as Ilhas são: Baia do Trapadé, entre as ilhas de Cananéia e do Cardoso; Mar de Itapitangui e de Cubatão, entre a Ilha de Cananéia e o Continente; Mar de Cananéia, entre as Ilhas de Cananéia e Comprida; Mar Pequeno, entre a Ilha Comprida e o continente. Miyao et al.(1986) indicam que esses canais ocupam uma área de $115 \mathrm{~km}^{2}$ de superfície.

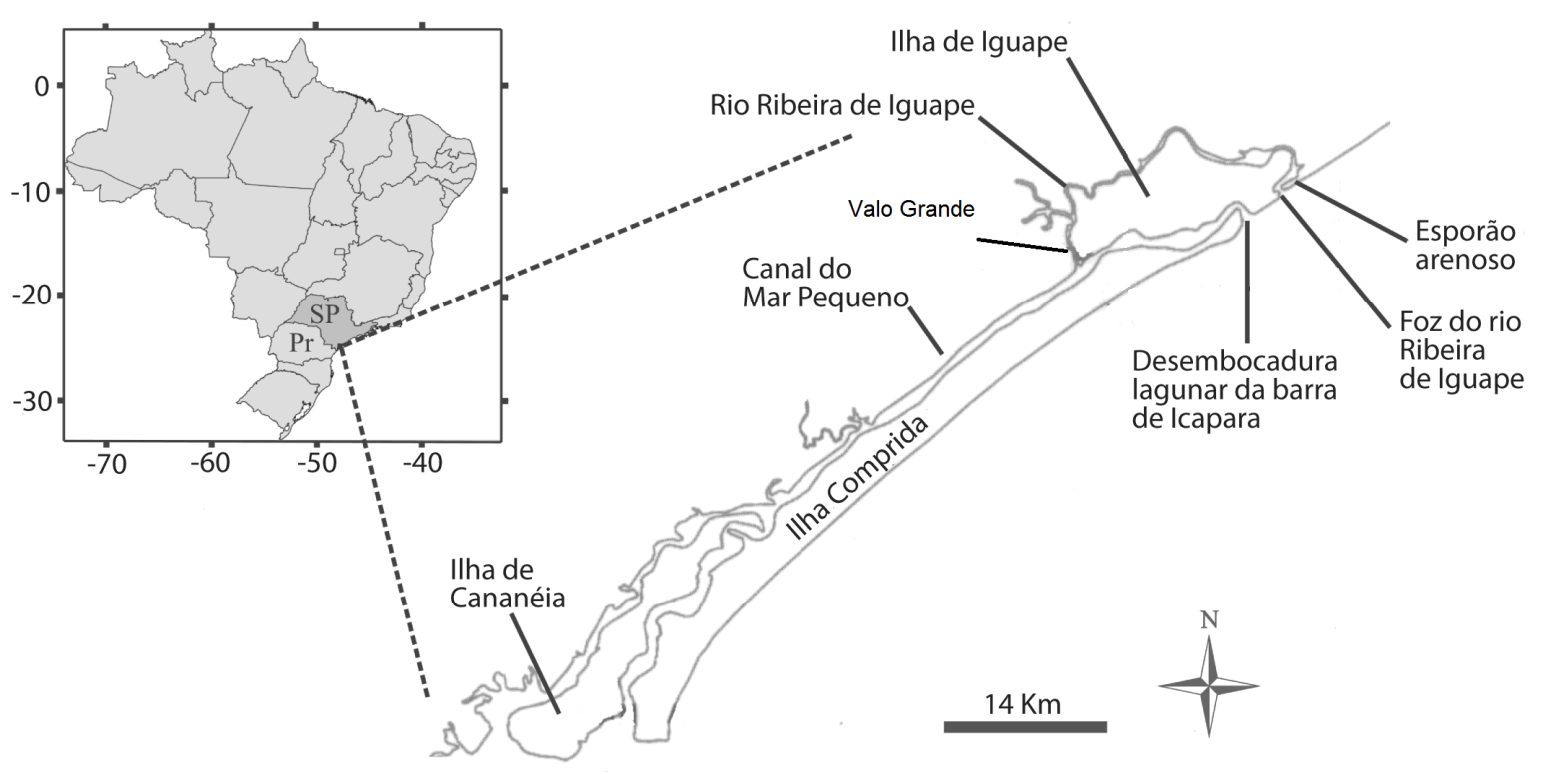

FIGURA 6 - Localização geográfica da área de estudo (Kawakurbo, 2009).

Esta região do litoral é de extrema importância devido à presença de extensas áreas de manguezais e de vegetação natural ainda em bom estado de preservação, além de 
possuir uma grande biodiversidade. Este complexo é constituído por um ecossistema altamente produtivo que recebe drenagem do Rio Ribeira de Iguape.

O litoral Sul é composto por 26 praias num total de $136 \mathrm{~km}$ de extensão que, devido à pequena ocupação e visitação turística, mantém a qualidade da água para balneabilidade em boas condições. A distância entre a Serra do Mar e o mar, resulta em uma ampla planície litorânea, ocupada pela Mata Atlântica e por amplas áreas de manguezais. Cananéia é o município com maior área de manguezal, seguido por Iguape.

\subsection{Características do sistema Estuarino Cananéia-Iguape}

Relatos do século XVII referem-se ao desembarque de produtos por embarcações pequenas no antigo "Porto Velho da Ribeira", em Iguape, localizado em frente ao trecho lagunar do Mar Pequeno, próximo à extremidade sudoeste do Morro de Icapara (Geobrás, 1966). Nessa época, a Ilha Comprida era, supostamente, quase uma dezena de quilômetros menor e o porto situava-se numa região mais aberta ao mar e, portanto, menos assoreada. Navegando rio Ribeira de Iguape abaixo, as embarcações que chegavam a uma distância em linha reta de $3 \mathrm{~km}$ do porto eram obrigadas a continuar viagem por mais $53 \mathrm{~km}$ através dos meandros do rio, do oceano e da desembocadura lagunar para, só então, já na laguna, fazer o desembarque em Iguape. No referido ponto de maior proximidade do porto, uma inflexão em "V" desviava o Ribeira de Iguape de desembocar na laguna, e próximo dele, encontrava-se uma "grande lagoa em forma de meia circunferência" (Geobrás, 1966). Em 1827, tiveram início às obras de criação de um atalho através desta "lagoa", mais precisamente um lago de meandro abandonado, através da abertura de um canal chamado "Valo do Rocio", posteriormente designado "Valo Grande" (Geobrás, 1966; Teles, 1997).

O Valo Grande é um canal artificial que liga diretamente o Rio Ribeira de Iguape com o Mar Pequeno. Foi construído entre 1827 e 1852 e tinha, originalmente, $4 \mathrm{~m}$ de largura e $2 \mathrm{~m}$ de profundidade. Com o passar dos anos, devido à pouca resistividade do material que compunha seu leito e margens, transformou-se no caminho preferencial do rio em direção ao oceano, apresentando erosão contínua de suas margens e ameaçando as construções da cidade de Iguape. Suas dimensões no fim do século XIX já superavam 100 $\mathrm{m}$ de largura e $10 \mathrm{~m}$ de profundidade (Geobrás, 1966). 
O Valo Grande foi fechado em 1978 quando alcançou $250 \mathrm{~m}$ de largura e $7 \mathrm{~m}$ de profundidade, com a construção de uma barragem situada à cerca de 2,5 km ao norte do Mar Pequeno. A obra visava evitar a continuidade do processo erosivo nas margens do canal, impedir a chegada anual de $90 \times 10^{8} \mathrm{~m}^{3}$ de água e 2,6 milhões de toneladas de material sólido para o sistema (Geobrás, 1966). Antes do fechamento, a salinidade mínima em todo sistema variava de 0 a 22 e os valores máximos de 14 a 32. Depois do fechamento estes valores passaram, respectivamente, para 16 a 30 e 26 a 34 (DAEE, 1989). O canal continuou fechado durante alguns anos, até ser rompido durante as enchentes de 1983, sendo posteriormente reconstruído. Em Fevereiro de 1995, devido à outra grande enchente e ao forte assoreamento, a barragem do Valo Grande foi novamente reaberta, modificando mais uma vez as condições ecológico-ambientais do sistema estuarino-lagunar. Desde então o canal permanece aberto, permitindo que $70 \%$ da carga de material e água doce do Rio Ribeira de Iguape, deságüe no sistema.

O tombo das águas do Mar Pequeno é de grande interesse, uma vez que a água que penetra no sistema Cananéia-Iguape pela desembocadura lagunar norte (Barra de Icapara) é acrescida pela água advinda do Rio Ribeira de Iguape através do canal Artificial do Valo Grande, caracterizando como o local de maior volume de água (Freitas, 2005).

Em estudos realizados por Zato (1966) ao redor da Ilha Comprida, foram analisados alguns parâmetros físico-químicos e verificou-se que a maior parte da água oceânica que penetra na região estuarino-lagunar, durante a maré enchente através da Barra de Cananéia, toma a direção oeste, pela Baía do Trapandé, enquanto uma quantidade menor entra pelo Mar de Cananéia. E durante a maré vazante, com a retirada da água do sistema, observou uma grande velocidade de correntes através da estreita passagem do Mar de Cananéia.

Entre os anos de 1882 a 1965 a Ilha Comprida cresceu aproximadamente 2.800 metros em sua direção predominante para o nordeste. No entanto, este crescimento se fez de modo irregular ao longo dos anos. Já o recuo da ilha de Iguape provocada pelos processos erosivos em suas margens foi considerado mais regular que o crescimento da Ilha Comprida, havendo uma retração média de 32 metros por ano. Cálculos realizados indicam que cerca de $60.000 \mathrm{~m}^{3}$ de sedimentos arenosos foram removidos anualmente da Ilha de Iguape (Geobrás, 1966). O estudo integrado de mais de 130 anos de registros 
históricos de mudanças ocorridas no extremo nordeste da Ilha Comprida pode ser visto na FIG. 7.
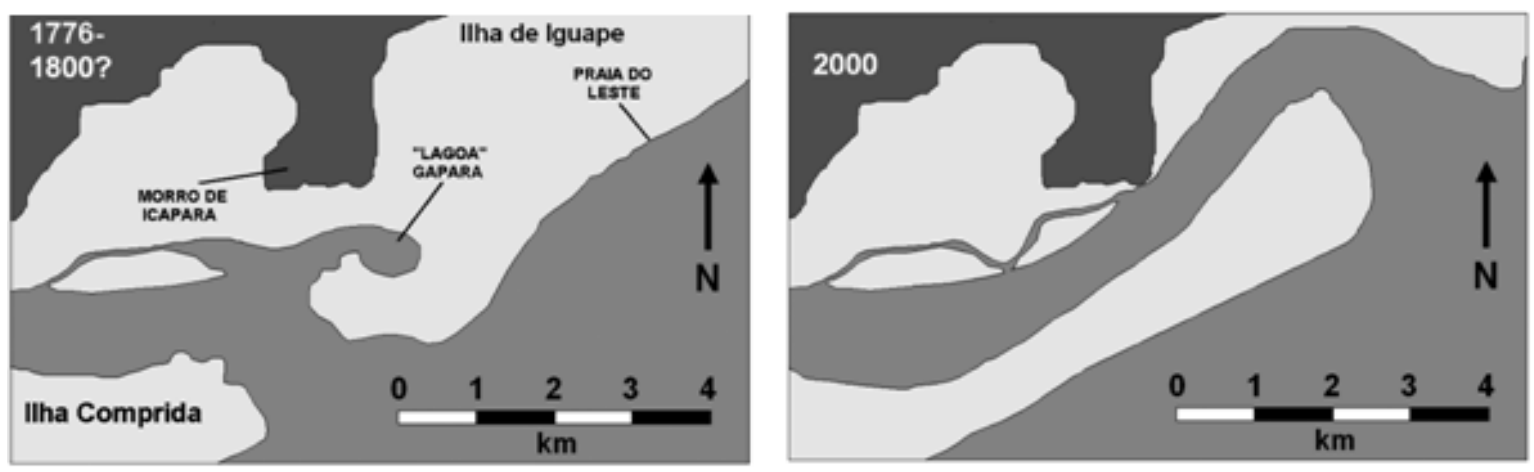

FIGURA 7 - Registro histórico das mudanças ocorridas no entorno do extremo nordeste da Ilha Comprida, no final do século XVIII (1776-1800?) e no ano de 2000 (Nascimento, 2008).

Além do deslocamento do canal de Icapara rumo NE, destacam-se também:

$\checkmark$ Grande variação da largura na extremidade nordeste da Ilha Comprida, com destaque para a região correspondente ao atual campo de dunas ativo (Nascimento, 2008);

$\checkmark$ Existência de feições intermitentes, como um antigo embaiamento lagunar imediatamente a sul do morro de Icapara ("lagoa" Gapara), surgimento e desaparecimento de um esporão arenoso na praia da Ilha Comprida. (entre os km 59 e 60), rumo do Sudoeste ao Nordeste (Nascimento, 2008).

A extensão total do sistema ocupa uma área aproximada de 10.000 ha, cobrindo desde a foz do Rio Ribeira até a Barra de Ararapira, na divisa entre os Estados do Paraná e São Paulo. A morfologia de fundo desses corpos d'água é de geometria variada, exibindo, entretanto, sempre um canal mais profundo de circulação associado a um flanco mais raso. As margens do sistema apresentam feições condicionadas pelas correntes de maré, e nas desembocaduras feições condicionadas pelas interações entre as correntes de maré e as correntes de deriva longitudinais (Tessler, 1982; Tessler, 1990; Tessler \& Furtado, 1983).

Estudos realizados por Miyao \& Harari (1989) em relação à maré e as correntes de maré, com base na análise de séries temporais, demonstrou que a circulação nessa região é 
predominantemente gerada pela maré semi-diurna, com valores extremos de 0,83 m e 0,13 m para amplitudes de sizígia e de quadradura, respectivamente.

A direção predominante do transporte de sedimentos ao longo da linha de costa ocorre para extremidade Nordeste (correntes de deriva litorânea geradas por sistemas de ondas incidentes do Sul ao Sudoeste). No canal lagunar, a corrente de maré vazante possui o mesmo sentido da corrente de deriva litorânea, ou seja, NE. A interação destas duas correntes na desembocadura lagunar provoca, segundo Tessler \& Mahiques (1993), o crescimento da Ilha Comprida para NE e a erosão da Ilha de Iguape.

A região de Cananéia apresenta uma temperatura do ar anual média de $21,4^{\circ} \mathrm{C}$, sendo em Fevereiro a mais alta média mensal $\left(25,2^{\circ} \mathrm{C}\right)$ e em Julho a mais baixa $\left(17,7^{\circ} \mathrm{C}\right)$. As chuvas estão relacionadas com as estações do ano, com verão chuvoso e inverno seco. $\mathrm{O}$ período mais chuvoso se estende de Dezembro a Abril, com uma média mensal de 200 $\mathrm{mm}$; e o período mais seco, de Maio a Novembro, com valor médio de $80 \mathrm{~mm}$. Durante todo o ano a região apresenta altos valores de umidade relativa do ar, com uma média anual de 88\%; a máxima de Março a Outubro igual a 89\%; mínima de Novembro a Janeiro igual a 87\% (Bérgamo, 2000; CRH- RB, 2010).

Estudos realizados por Bérgamo (2000) mostraram que a salinidade teve grandes intervalos de variação em relação região sul e norte do sistema estuarino de Cananéia e Iguape. A primeira região, por receber uma carga de água doce menor, apresentou valores de salinidade variando entre 19,0 e 34,0 no inverno, e entre 11,0 e 34,0 no verão. Já a região norte, que sofre influência da descarga de água doce do Valo Grande, apresentou salinidades próximas a zero na desembocadura deste canal, sendo na região da Barra de Icapara a salinidade variou entre 10,0 e 35,0 no inverno e 1,2 e 32,0 no verão.

Na região de Iguape a temperatura média é da ordem de $21,5^{\circ} \mathrm{C}$. A precipitação média anual é de $1.653 \mathrm{~mm}$. Quanto às variações na precipitação média ao longo do ano, nos meses secos, Julho e Agosto, a média mensal variou entre 78,4 e 83,2 mm; e nos meses chuvosos, de Dezembro a Março, a média mensal variou entre 157,6 e 229,8 mm (CRH$\mathrm{RB}, 2010)$. 
Estudos conduzidos pela CETESB (2007) evidenciaram que as concentrações de nutrientes inorgânicos dissolvidos no sistema na estação seca são similares nas regiões sul e norte. No entanto, quando aumenta a carga fluvial através do Valo Grande, na estação chuvosa, os teores de nutrientes na região norte são bem superiores ao encontrados na região de Cananéia.

\subsection{A contribuição das águas do Alto Vale do Ribeira para o cenário estudado}

É possível observar que as vazões fluviais do Estado de São Paulo ocorrem no sentido interior desaguando no Rio Grande e posteriormente no Rio da Prata. Nesse universo hídrico, o Rio Ribeira de Iguape constitui o principal rio da vertente litorânea do Estado de São Paulo, apesar da sua nascente se localizar no Estado do Paraná. Entretanto, na região do Alto Ribeira o divisor de águas entre a vertente litorânea do Rio Ribeira e a vertente interiorana do Rio Paranapanema é a Serra Paranapiacaba.

No sentido de melhor perceber a densidade natural do Alto Vale do Ribeira é preciso percorrer o interior dos vales, e observar os rios com suas correntes, as inúmeras cachoeiras, a cobertura vegetal com os aspectos de seus diferentes estratos e, sobretudo, as cavernas com intrínsecos sistemas de drenagem subterrânea, compreendendo sumidouros e ressurgências por meio dos quais a água percorre tortuoso caminho até o Rio Ribeira de Iguape. Registra-se que o vale deste curso d'água segue padrão extremamente inclinado e retilínio em forma de "V", fisiografia peculiar decorrente da ação desigual de agentes erosivos nas lentes de calcário e filito (Allegrini, 1997).

A região tem um enorme potencial turístico, principalmente relacionado ao ecoturismo, como resultado do estado de conservação de seus ecossistemas e pela variedade de atrativos encontrados. A demanda pelo ecoturismo vem sendo desenvolvida de uma forma crescente, mas pouco planejada. As principais atrações são: exploração de cavernas, trilhas ecológicas, visitação a parques e praias, pesca esportiva, etc.

Vários estudos, realizados a partir da década de 1980, comprovaram inequivocamente que a bacia do Rio Ribeira foi muito afetada pelas atividades econômicas levadas a efeito na região, em especial, pela atividade de mineração e metalúrgica do Alto Vale. Esses efeitos tornaram-se visíveis na contaminação dos sedimentos fluviais por 
chumbo, zinco, cobre e arsênio, e, mais episodicamente, pelo registro de elevadas concentrações de metais nas águas (Tessler et al., 1987; Eysink et al., 1988; Moraes, 1997; Silva, 1997; CETESB, 2006).

O Vale do Ribeira abriga a grande maioria das cavernas paulista. Nessa província espeleológica encontram-se os mais profundos abismos brasileiros e também cavernas de expressivo tamanho, como a Caverna do Diabo, no Parque Estadual Jacupiranga, e a Caverna Santana, no Parque Estadual Turístico do Alto Ribeira - PETAR. Essa região calcária é a única no Brasil onde predominam condições favoráveis formação de cavernas cujas profundidades podem superar 300 metros (Giatti et al., 2004). A elevada ocorrência de cavidades subterrâneas na região e a singularidade desses ambientes refletem-se na particular biota encontrada nos ambientes carvernícolas.

Estudo sobre impactos ambientais realizado por Giatti (2004) no Alto Vale do Ribeira, verificou a implantação de um aterro situado na estrada que liga Iporanga à portaria Casa de Pedra do PETAR, onde o lixo é lançado em valas e queimado, para posterior cobertura com terra, manejo inadequado de resíduos que acarreta impactos ambientais pela liberação de gases tóxicos e contaminação do lençol freático.

Giatti et al.(2004) também verificou níveis de coliformes fecais e totais na água em pontos considerados de influência por lançamento de esgotos domésticos. Foram selecionados quatro pontos de coleta de amostras de água: no Rio Betari, à montante do Bairro da Serra, onde a vazão mínima do corpo d'água é de $4 \mathrm{~m}^{3} / \mathrm{s}$; no Córrego Seco e no Córrego Monjolo. Ambos são tributários do Rio Betari, cortam o Bairro em áreas mais habitadas e constituem fios de água nascente que em determinados períodos de estiagem se apresentam praticamente sem correnteza. No quarto ponto a coleta foi feita no Rio Betari, à jusante do Bairro da Serra e da confluência com o Córrego do Gaúcho, outro corpo d'água de pequena vazão que corta o bairro.

A complexidade de relações entre bacia hidrográfica e unidade de atividade pode ser observada na bacia do Rio Betari. Ela sofre influência tanto de atividades agrícolas que acaba interferindo negativamente no ecossistema aquático no interior do parque, como também, pelo crescimento populacional do fluxo turístico. 


\subsection{Padrões de qualidade e uso dos recursos hídricos na região do Vale do Ribeira e litoral Sul do Estado de São Paulo}

As águas superficiais do território nacional seguem classificação e padrões de qualidade determinados pela Resolução 357/2005 do Conselho Nacional do Meio Ambiente (Conama). Esta resolução classifica as águas doces (salinidade $<0,5 \%$ ), salobras (salinidade entre 0,5 e $30 \%$ ) e salinas (salinidade $>30 \%$ ) do Território Nacional de acordo com a qualidade requerida para seus usos preponderantes e as divide em treze classes de qualidade.

De acordo com o Decreto Estadual $N^{o} 38.455$, de 21/03/94 toda a Bacia hidrográfica do Rio Ribeira de Iguape agrega 23 municípios em uma área de $16,771 \mathrm{~km}^{2}$ (ITESP, 2000). Na região encontram-se a Área de Proteção Ambiental da Serra do Mar, o Parque Estadual do Alto Ribeira - PETAR e o Parque de Jacupiranga.

A Bacia hidrográfica do Ribeira de Iguape, denominada também de Vale do Ribeira e Unidade de Gerenciamento de Recursos Hídricos 11, Vale do Ribeira e Litoral Sul (UGRHI - 11), tem uma extensão aproximada de $260 \mathrm{~km}$ (FIG. 8), dos quais cerca de $17.000 \mathrm{~km}^{2}$ (dois terços) estão no território paulista (CETESB, 2006).

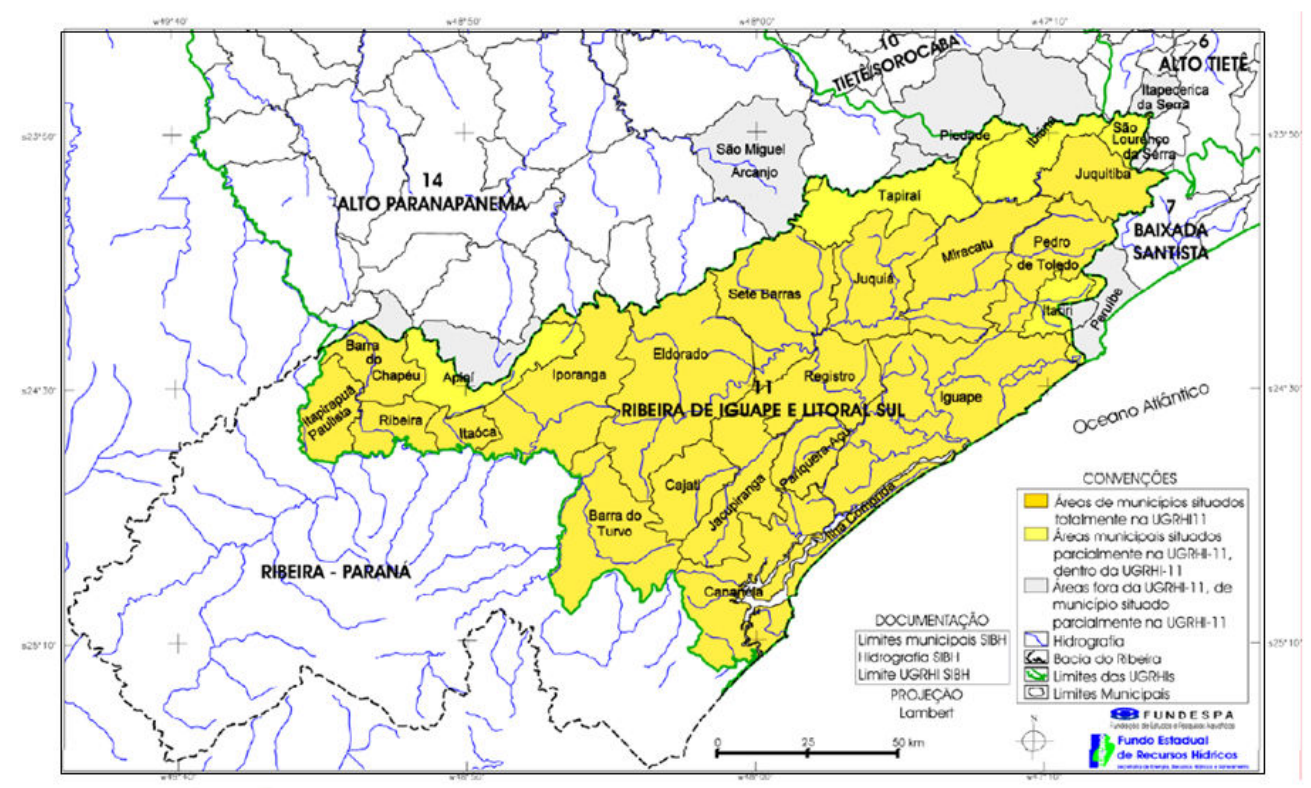

FIGURA 8 - Bacia Hidrográfica do Rio Ribeira de Iguape e Litoral Sul (CBH-RB, 2007) 
A área total da Bacia é de $25.681 \mathrm{~km}^{2}$ incluindo a porção paranaense. As maiores cidades localizada na UGRHI 11 são Registro, Cajatí, Iguape e Apiaí, com uma área de drenagem de $17.068 \mathrm{~km}^{2}$ (CRH- RB, 2010).

O Gerenciamento de Recursos Hídricos do Ribeira de Iguape e Litoral Sul apresenta características muito singulares, como os mais baixos índices de desenvolvimento do estado, uma economia baseada principalmente na agricultura (banana, chá e arroz), mineração e extrativismo vegetal (palmito). Os parâmetros socioeconômicos e demográficos apresentam uma imagem contrastante com o resto do estado. Além disso, é uma região peculiar por ser uma das áreas menos urbanizadas do estado.

Quase a totalidade da água para abastecimento público na região do Vale do Ribeira provém de captações superficiais (97\%). Apenas Barra do Chapéu e Itapirapuã, além de alguns bairros ou distritos localizados nos municípios de Eldorado, Sete Barras, Registro, São Lourenço, Miracatu, Itariri, Pedro de Toledo e Cajati captam águas por poços profundos (CETESB, 2006).

Segundo os parâmetros do Conselho Nacional do Meio Ambiente - CONAMA n ${ }^{\mathbf{0}}$ 357/053, todos os corpos d'água da região do Vale do Ribeira, foram enquadrados na Classe 2 (águas que podem ser destinadas ao abastecimento humano, após tratamento convencional). Com exceção dos rios Sete Barras, Turvo e seus afluentes, São João, Córrego dos Veados, Córrego Poço Grande, Rio João Surrá e seus afluentes que pertencem à Classe 1 (águas que podem ser destinadas ao abastecimento para consumo humano, após tratamento simplificado).

Na Bacia Hidrográfica do Rio Ribeira de Iguape e Litoral Sul os corpos d'água estão enquadrados nas Classes 1 e 2 conforme as TAB. 1 e 2. 
TABELA 1 - Corpos d'água da Classe 1 (abrangendo a especial CONAMA).

Classe especial - Águas destinadas:

a) ao abastecimento para consumo humano, com desinfecção;

b) à preservação do equilíbrio natural das comunidades aquáticas; e

c) à preservação dos ambientes aquáticos em unidades de conservação de proteção integral.

Classe 1 - águas destinadas:

a) ao abastecimento doméstico após tratamento simplificado;

b) à proteção das comunidades aquáticas;

c) à recreação de contato primário (natação, esqui aquático e mergulho);

d) à irrigação de hortaliças que são consumidas cruas e de frutas que se desenvolvem rentes ao solo e que sejam consumidas cruas, sem remoção de películas; e à criação natural e/ou intensiva (aqüicultura) de espécie destinadas à alimentação humana.

\section{Corpos d'água enquadrados:}

Rio Juquiá e todos os seus afluentes até a divisa dos Municípios de Juquitiba e Micatu. (conforme Decreto No 43.594, de 27 de Outubro de 1998, Moção CBH-RB 01/98, Rio São Lorenço).

Fonte: CBH-RB, Comitê da Bacia Hidrográfica do Ribeira de Iguape e Litoral Sul.

TABELA 2 - Corpos d'água da Classe 2.

Classe 2 - águas que podem ser destinadas:

a) ao abastecimento para consumo humano, após tratamento convencional;

b) à proteção das comunidades aquáticas;

c) à recreação de contato primário,tais como natação, esqui aquático e mergulho, conforme Resolução CONAMA n. 274, de 2000;

d) à irrigação de hortaliças, plantas frutíferas e de parques, jardins, campo de esporte e lazer, com os quais o público passa vir ter contato direto; e

e) à aqüicultura e a à atividade de pesca.

\section{Corpos d'água enquadrados:}

Todos, exceto os alhures classificados.

Fonte: CBH-RB, Comitê da Bacia Hidrográfica do Ribeira de Iguape e Litoral Sul.

A demanda por recursos hídricos na região representa $3,39 \%$ de sua disponibilidade. Apresentam-se, fundamentalmente, três usos para os recursos hídricos:

- Uso doméstico - a empresa concessionária que administra o sistema estadual de água e esgoto é a SABESP. A bacia do Ribeira apresenta um panorama bastante heterogêneo, com municípios de baixíssimo consumo, como é o caso de Itaoca $\left(0,007 \mathrm{~m}^{3} / \mathrm{s}\right)$ ou grandes 
consumidores como é o caso de Registro e Iguape $\left(0,163 \mathrm{~m}^{3} / \mathrm{s}\right.$ e $0,145 \mathrm{~m}^{3} / \mathrm{s}$, respectivamente).

- Uso Industrial - os maiores consumidores na região são a Serrana Mineração e a Fazenda Vale do Eta, com uma captação de $1,29 \mathrm{~m}^{3} / \mathrm{s}$ e $0,98 \mathrm{~m}^{3} / \mathrm{s}$ dos rios Jacupiranguinha e Eta, de acordo com o Cadastro de Usuários de Recursos Hídricos do DAEE (Departamento de Águas e Esgotos).

- Uso na irrigação - a demanda para irrigação estimada é de $2,3 \mathrm{~m}^{3} / \mathrm{s}$. Um dos principais meios de captação de águas subterrâneas é através de poços. Contudo pouquíssimos deles são realmente regularizados por lei, através das Outorgas.

Os rio Ribeira apresentou qualidade de água boa, de acordo com a IAP em 2005. No entanto, o rio Jacupiranga e o trecho final do Rio Ribeira de Iguape tiveram suas qualidades enquadradas na categoria regular, devido à elevada concentração de fósforo total, bem como do alumínio, manganês e ferro (CETEB, 2006).

Mesmo tendo um sistema de tratamento de esgoto implantado na região, os pequenos municípios têm menos que $70 \%$ do esgoto produzido coletado. Os tipos de tratamento mais encontrados utilizam lagoas aeradas e facultativas. Mesmo as grandes cidades encontram problemas em seus sistemas em função das enchentes. A CETESB (2006) controla as fontes poluidoras de origem industrial nos municípios de Cananéia, devido à preparação de pescados e beneficiamento de camarão (gera uma carga orgânica de cerca de 4,46 t/ano) e de Cajati devido à fabricação de produtos químicos (gera carga orgânica de 6,21 t/ano).

Tradicionalmente o sistema Cananéia-Iguape é classificado como ambiente eutrofizado, porem os teores de fósforo encontrados nos estudos mostraram que está havendo um processo de eutrofização antrópica, conduzindo a região a uma situação hipereutrofização.

Segundo a CETESB (2006), em Julho de 2005 foi registrado um aumento significativo na concentração de fósforo total de $25,0 \mu \mathrm{M}$ no Valo Grande de Iguape próximo a desembocadura desse canal, passando para o estado hipereutrófico. Na Barra de Icapara 
houve uma diminuição na concentração de fósforo total para 13,0 $\mu \mathrm{M}$, que corresponde ao estado eutrófico. O valor muito elevado de fósforo total observado no Valo Grande pode estar relacionado à criação de búfalos. Tal atividade está possivelmente contribuindo para a eutrofização do rio, tanto em função dos dejetos produzidos pelos animais como pela ação do pisoteio nas margens, que promove o revolvimento dos sedimentos ricos em fósforo para a coluna de água. Este aumento de fósforo está tendo efeitos sobre as comunidades aquáticas na região estuarina, tendo sido detectada a presença de macrófitas de água doce, tanto no Valo Grande como em toda a região note do sistema estuarino (CRH-RB, 2010).

Outro problema notificado pelo Centro de Referência em Saúde do Trabalhador Regional do Vale do Ribeira é a aplicação excessiva e mal executada de agrotóxicos, resultando que a região apresenta o quarto lugar em casos notificados de intoxicação por agrotóxicos (mesmo sendo uma das menos povoadas) e o maior percentual de mortes por essa causa.

\subsection{A Foz do Rio Ribeira}

Como já foi mencionado, o Rio Ribeira de Iguape é o maior constituinte de água doce para o sistema estuarino-lagunar, e estimativas recentes da descarga de água de doce nesse sistema, através de séries temporais de temperatura do ar, precipitação e evaporação, ao longo dos anos de 1965 a 1997, foram estudadas por Bérgamo (2000). A média anual estimada da bacia de drenagem do rio Ribeira de Iguape foi de $773,56 \mathrm{~m}^{3} / \mathrm{s}$, e a média mensal, está entre máxima no mês de Março com $751 \mathrm{~m}^{3} / \mathrm{s}$ e mínima no mês de Agosto com $99 \mathrm{~m}^{3} / \mathrm{s}$. O Rio Ribeira contribui com uma descarga de sólidos no sistema, através do Valo Grande, da ordem de $1.000 .000 \mathrm{~m}^{3} / \mathrm{s}$ de sedimentos finos em suspensão (CRH- RB, 2010).

A bacia de drenagem próxima a Cananéia, onde se localizam o Mar de Cananéia, o Mar de Cubatão e a Baia de Trapandé é drenada por uma pequena rede hidrográfica, cujos os rios principais contribuem com uma descarga média de $47,24 \mathrm{~m}^{3} / \mathrm{s}$ com valores máximo em Março com 99,8 $\mathrm{m}^{3} / \mathrm{s}$ e mínimo em Agosto com 5,8 $\mathrm{m}^{3} / \mathrm{s}$. 


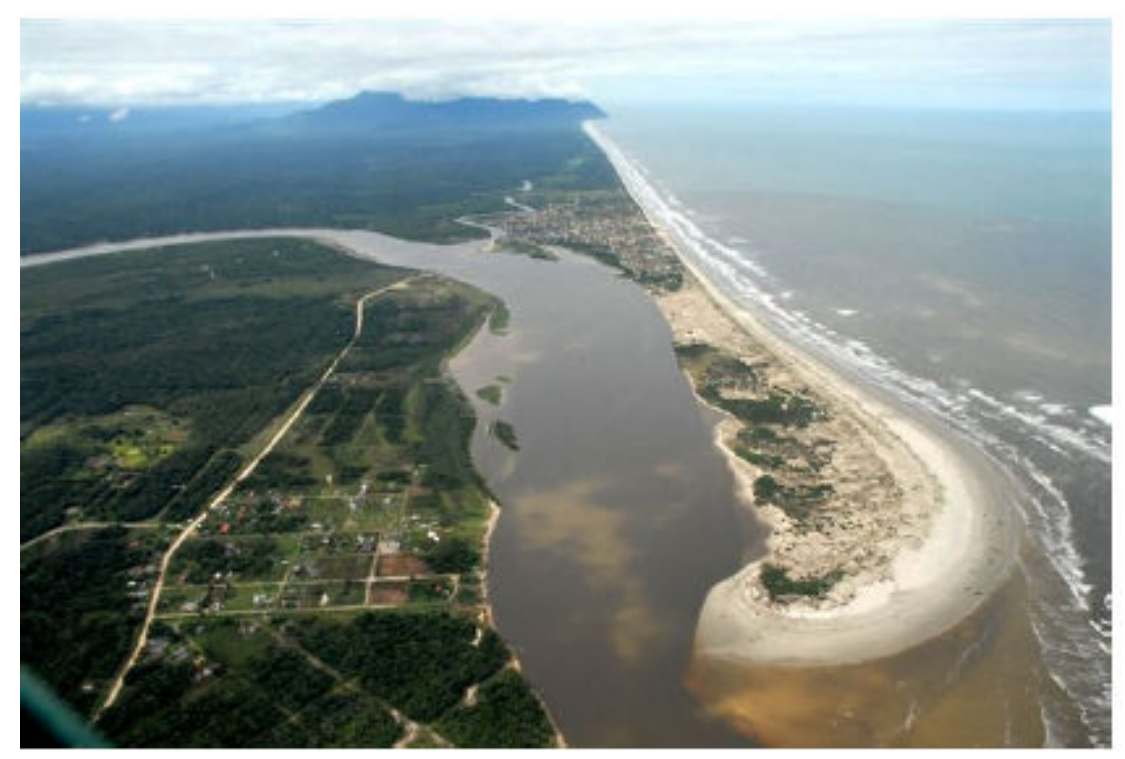

FIGURA 9 - A Foz do Rio Ribeira de Iguape.

Duas importantes feições geográficas são encontradas próximo à Ilha de Iguape, a desembocadura lagunar da Barra do Icapara (delimitada por uma ilha barreira chamada de Ilha Comprida) e a foz do rio Ribeira de Iguape. Esta área é caracterizada por um intenso processo morfodinâmico de crescimento da Ilha Comprida para Nordeste (NE), erosão da Ilha de Iguape na margem esquerda da desembocadura lagunar da Barra do Icapara e crescimento de um esporão arenoso no sentido Sudoeste (SW) (Nascimento, 2008).

Na desembocadura lagunar e na foz do Rio Ribeira de Iguape, as correntes de deriva litorânea sofrem um bloqueio resultante dos fluxos da maré vazante e fluvial, que além de reter o deslocamento dos sedimentos para NE, também interfere nas características hidrodinâmicas locais (Tessler, 1988; Tessler \& Mahiques, 1993). 


\section{CAPÍTULO 5 - PARTE EXPERIMENTAL}

\subsection{Obtenção das fibras de acrílico impregnadas com dióxido de manganês para pré- concentração dos isótopos naturais de Ra de amostras de água}

Como os isótopos naturais de Ra encontram-se dissolvidos ao nível de traços e ultra-traços nas amostras costeiras e oceânicas, é necessário utilizar uma técnica de préconcentração destes elementos in situ a fim de se obter concentrações detectáveis dos mesmos nas etapas de separação radioquímica e contagem alfa e beta total. Neste trabalho, para preparação das colunas de fibras de acrílico impregnadas com $\mathrm{MnO}_{2}$, adquiriu-se um fardo de fibras de acrílico cortadas, de espessura 3,3 DTEX e $55 \mathrm{~mm}$ de diâmetro, produzidas pela Companhia Sudamericana de Fibras Brasil Ltda.

No laboratório de radioquímica, pequenas porções das fibras de acrílico limpas (cerca de 100 a $200 \mathrm{~g}$ ) foram mergulhadas em um béquer de 5 L contendo uma solução 0,5 $\mathrm{mol} / \mathrm{L}$ de permanganato de potássio, mantida à temperatura controlada de $80^{\circ} \mathrm{C}$, por cerca de 10 minutos. $\mathrm{O} \mathrm{KMnO}_{4}$ oxida sítios específicos da molécula de acrílico, depositando-se nestes locais na sua forma reduzida, como $\mathrm{MnO}_{2}$. A seguir, as fibras foram lavadas várias vezes com água purificada Milli-Q, para eliminação dos excessos de $\mathrm{KMnO}_{4}$ e $\mathrm{MnO}_{2}$, e deixadas em uma grade para redução do excesso de água com secagem por uma noite (FIG. 10). Após a secagem, as fibras de acrílico- $\mathrm{MnO}_{2}$ foram armazenadas em sacos plásticos e convenientemente guardadas até o instante da coleta.

As fibras de acrílico produzidas deste modo apresentam partículas submicrométricas de $\mathrm{MnO}_{2}$ ligadas quimicamente. $\mathrm{O} \mathrm{MnO}_{2}$ está presente na proporção de $8 \mathrm{a}$ $10 \%$ em massa nestas fibras tratadas quimicamente com $\mathrm{KMnO}_{4}$ (Rutgers van der Loeff \& Moore, 1999). A reação pode ser conduzida em um béquer ou em recipientes de 20 L. Se o procedimento for realizado em larga escala, é necessário notar que a reação é exotérmica, requerendo refrigeração para prevenir o superaquecimento, uma vez que o calor dissipado pode ocasionar acidentes. 


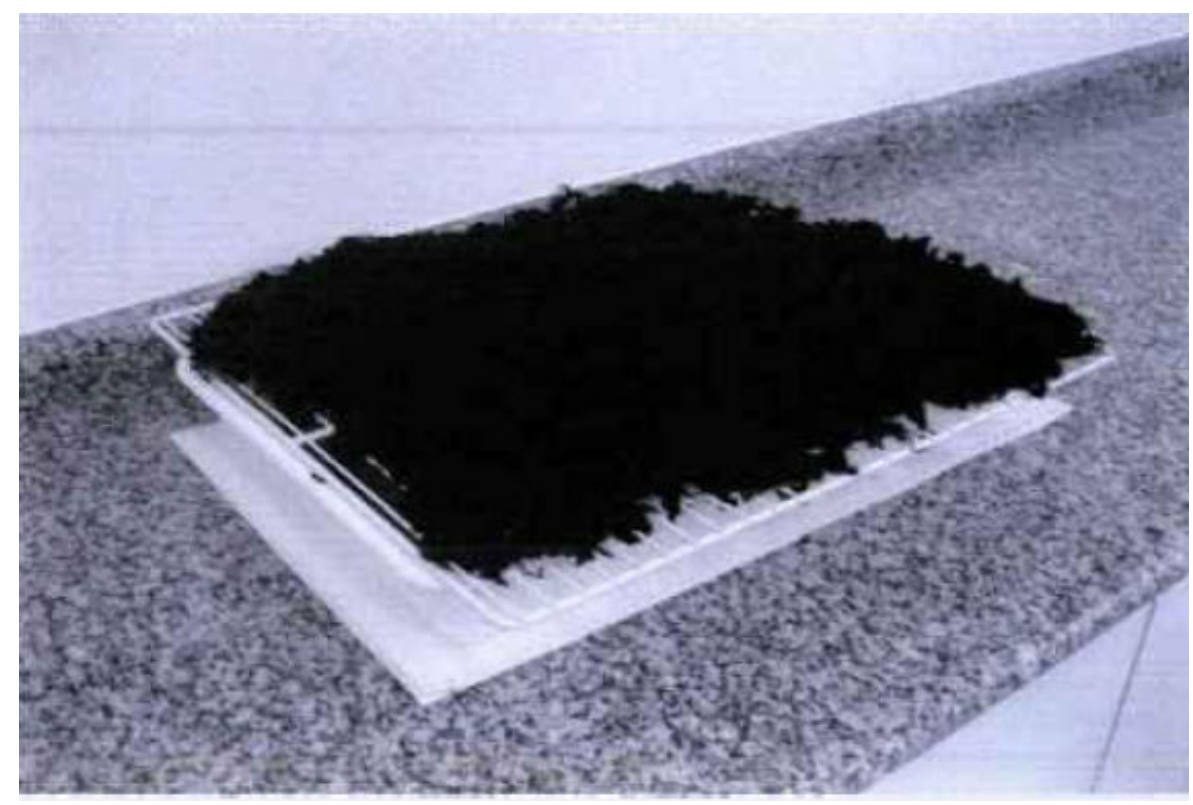

FIGURA 20 - Fibras de acrílico impregnadas com $\mathrm{MnO}_{2}$.

\subsection{Coleta das amostras de águas subterrâneas, águas de superfície e águas estuarinas}

Para os propósitos deste trabalho, foram realizadas 7 campanhas de amostragem (biênio 2009-2010) contemplando alíquotas de águas subterrâneas e de superfície, localizadas tanto na região estuarino-lagunar de Cananéia-Iguape quanto no Alto Vale do Ribeira, para se obter a distribuição dos 4 isótopos naturais de Ra. As amostras foram coletadas utilizando-se recipientes de polietileno com $10 \mathrm{~L}$ de capacidade, previamente limpos com uma solução do tensoativo Extran Alcalino (Merck). Após a coleta as amostras foram filtradas e aciduladas com ácido nítrico $0,1 \%$.

Estações hidroquímicas (11 estações) foram estabelecidas no Rio Ribeira de Iguape, na Barra de Cananéia e na Barra de Icapara, durante duas campanhas: a primeira foi realizada no período 10 a 12 de Fevereiro de 2009 a bordo da embarcação Albacora do Instituto Oceanográfico da USP, contabilizando 5 estações em Cananéia (CAN 1 a CAN 5), 5 estações localizadas em Iguape (IG 7 a IG 11) e 1 estação intermediária entre as duas regiões (IG 6); a segunda foi realizada de 18 a 22 de Agosto de 2009, nas mesmas posições anteriores (FIG.11). Além dos isótopos naturais de Ra foram coletadas amostras para ensaio de outros parâmetros físico-químicos a fim de se avaliar a distribuição das massas 
d'água, a disponibilidade de nutrientes e matéria orgânica, a degradação da matéria orgânica, a classificação do estado trófico e alguns outros aspectos da qualidade da água. Dentre os parâmetros analisados pode-se citar a temperatura, salinidade, $\mathrm{pH}$, oxigênio dissolvido, nitrato, nitrito, amônio, fosfato e sólidos totais em suspensão. Estas análises foram realizadas pelo Laboratório de Nutrientes, Micro-nutrientes e Traços no Oceano (LABNUT) do IOUSP.

A localização espacial geral das 11 estações hidroquímicas pode ser vista na FIG.11.

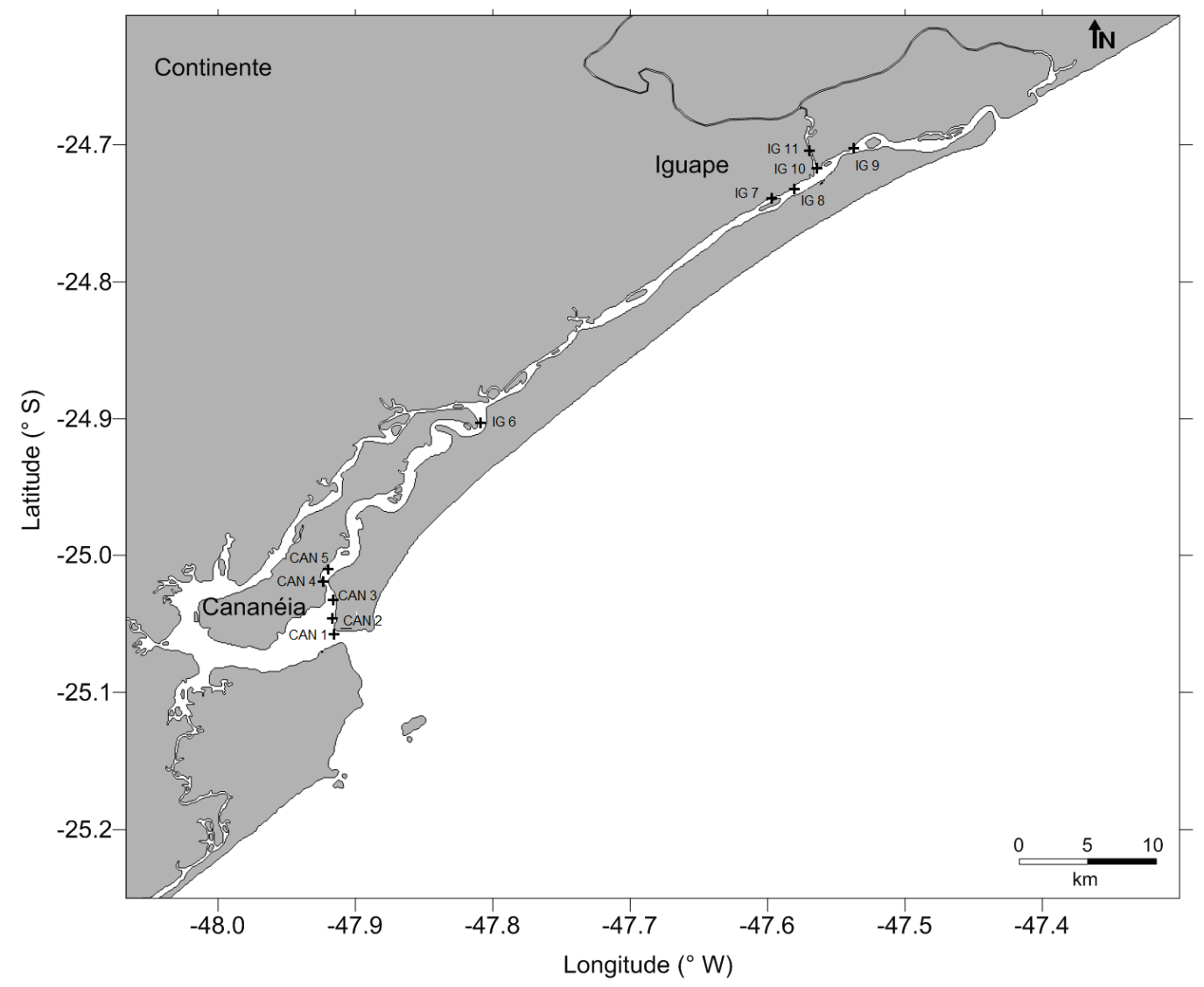

FIGURA 11 - Mapa apresentando as coordenadas geográficas dos pontos de amostragem (estações hidroquímicas), na região estuarino-lagunar de Cananéia-Iguape.

Para a coleta das amostras de água nas estações hidroquímicas, utilizou-se uma garrafa do tipo Van Dorn, fabricada em teflon (FIG. 12). As alíquotas foram tomadas em duas profundidades, superfície e fundo. Nas duas grandes campanhas, representivas das estações seca e chuvosa, respectivamente, foram coletadas 6 amostras de água superficial ao longo do Rio Ribeira de Iguape (FIG.13), logo após a barragem do Valo Grande (RIB 1 
a 6). Em Abril de 2009 e em Agosto de 2009, foram coletadas as amostras de águas subterrâneas em18 poços de monitoração localizados nas regiões de Cananéia (7 Poços), Ilha Comprida (6 Poços) e Iguape (5 Poços) (FIG.14 e 15).

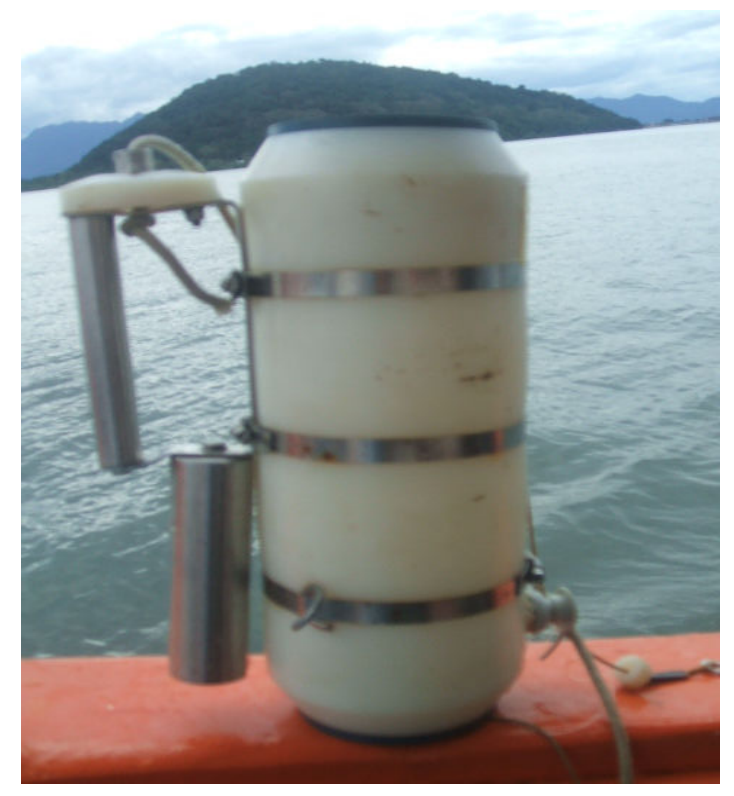

FIGURA 12 - Garrafa do tipo Van Dorn.

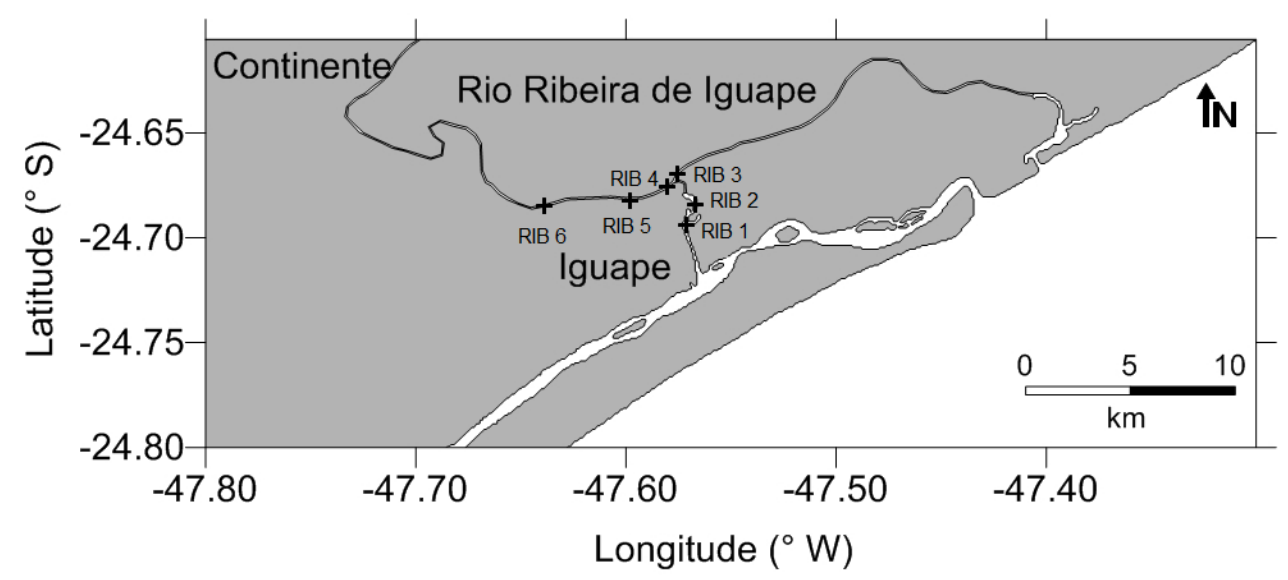

FIGURA 13 - Mapa da localização das estações hidroquímicas no Rio Ribeira de Iguape. 


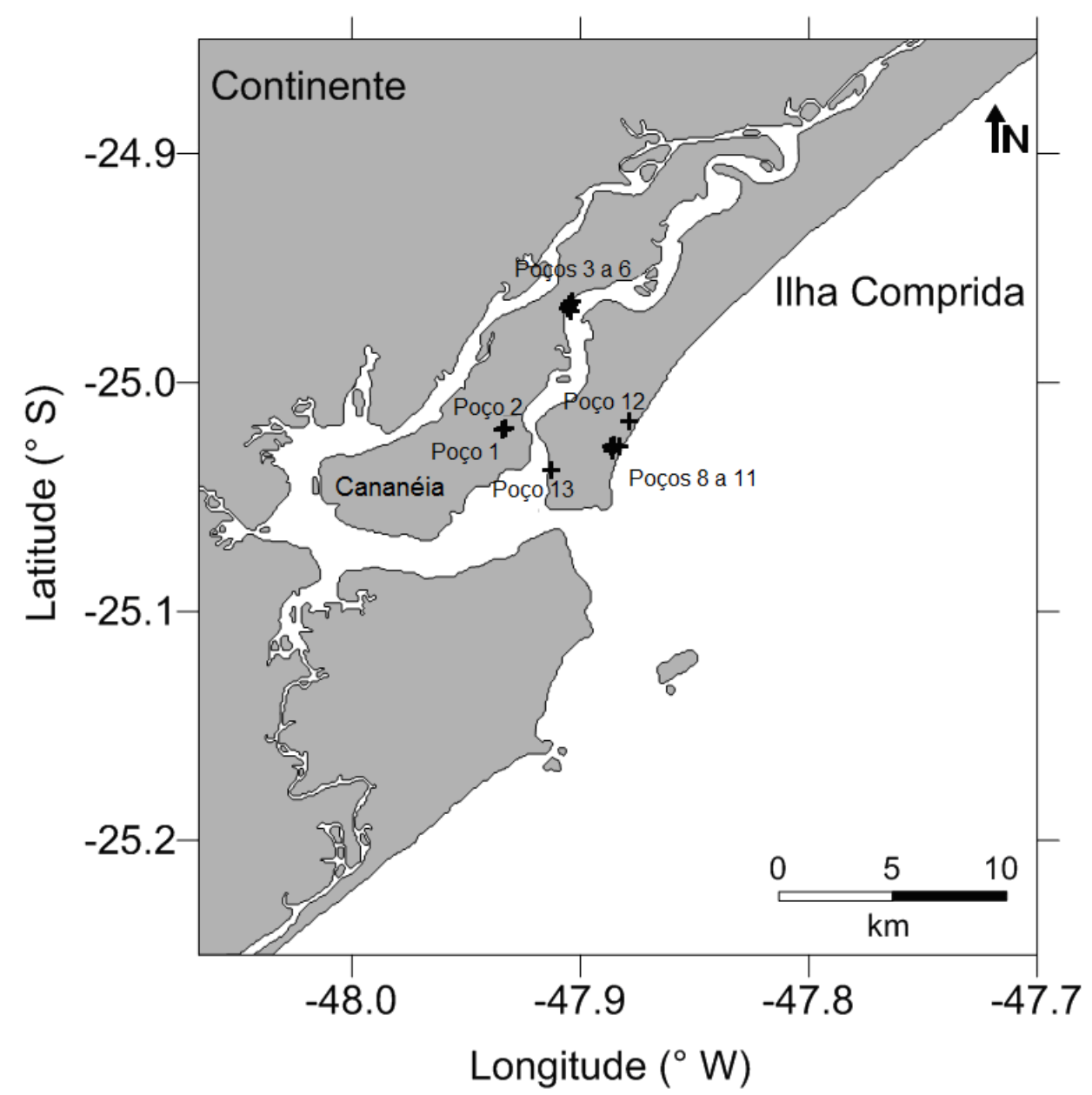

FIGURA 14 - Mapa da localização dos pontos de coleta das amostras de águas subterrâneas em Cananéia e Ilha Comprida.

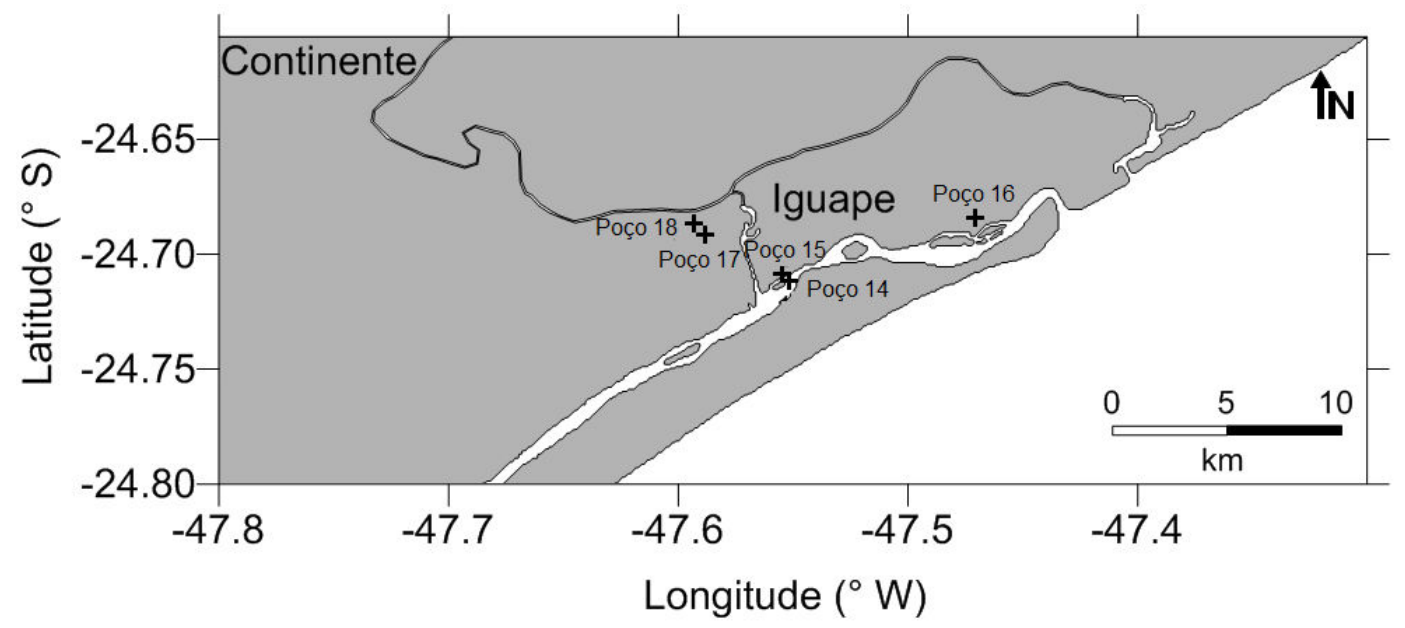

FIGURA 15 - Mapa da localização dos pontos de coleta das amostras de águas subterrâneas em Iguape. 
Em Cananéia, as amostras de águas subterrâneas foram tomadas nos seguintes pontos: 2 pontos localizados no centro da cidade (Poço 1 e Poço 2), e 5 pontos no conjunto Agro Solar (Poços 3 a 7). As amostras coletadas na Ilha Comprida foram tomadas nos seguintes pontos: 1 ponto próximo Hotel Inter Mares (Poço 8), 1 ponto no Hotel Inter Mares (Poço 9), 1 ponto no posto de saúde (Poço 10), 2 pontos às margens da praia de Ilha Comprida (Poços 10 a 12) e um ponto próximo a balsa, às margens do estuário de Cananéia (Poço 13). As amostras tomadas na cidade de Iguape seguem os seguintes pontos: 2 pontos no centro da cidade de Iguape (Poço 14 e 15) e 3 pontos no bairro de Morrete, às margens do Rio Ribeira de Iguape (Poço 17 a 18). Em 2010, repetiu-se a amostragem de águas subterrâneas novamente nas mesmas localidades acima em Abril e Maio (FIG.16).

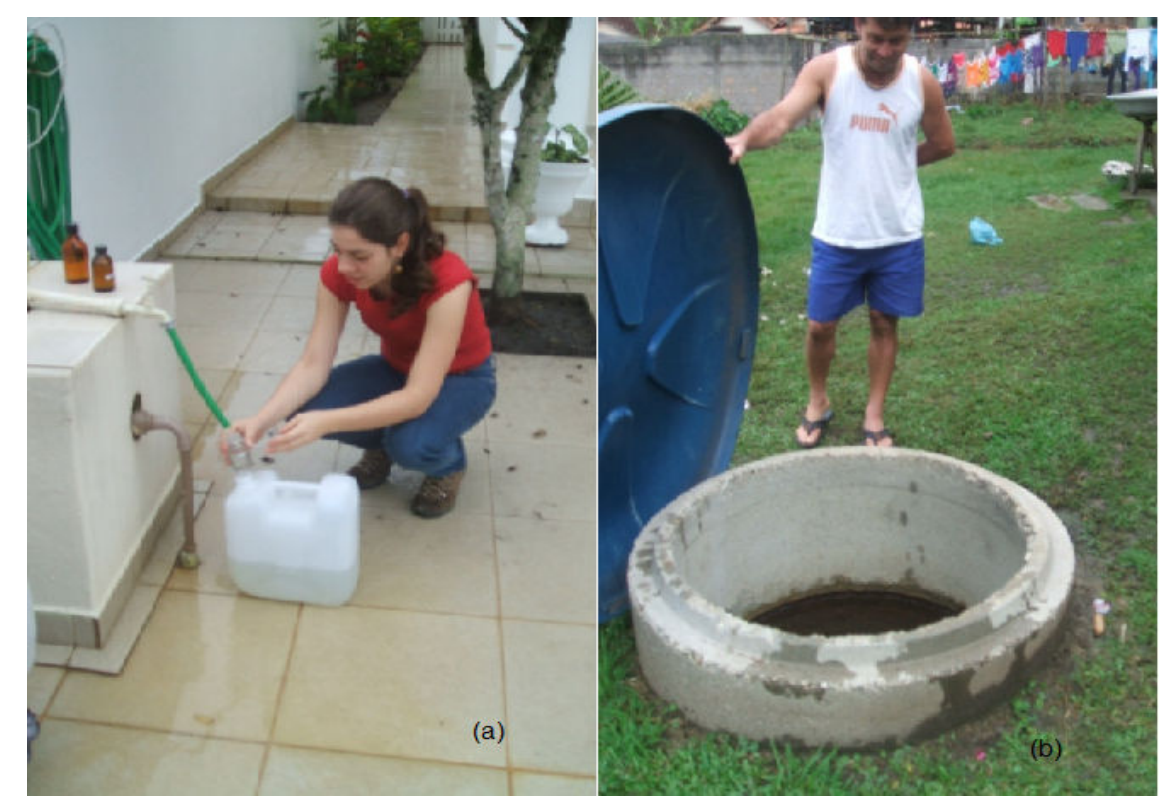

FIGURA 16 - Foto da amostragem de águas subterrâneas no Poço 6, no conjunto Agro Solares (a) e no Poço 2, na Cidade de Cananéia (b).

Quatro outras campanhas de amostragem foram realizadas na região do Alto Vale do Ribeira nos períodos de 28 a 29 de Abril/2009; 25 a 27 de Setembro/2009; 23 a 24 de Outubro/2009; 29 de Novembro de 2009, perfazendo um total de 35 pontos de coleta (FIG. 17 a 19). Estas amostras foram coletadas para se inventariar e conhecer os níveis naturais de referência dos isótopos de Ra nas águas do Alto Vale do Ribeira que contribuem para a bacia de drenagem do Rio Ribeira do Iguape. Neste último levantamento, foram amostrados 7 pontos na cidade de Iporanga, nos seguintes locais: Caverna Santana (A1), Caverna Água Suja (A2), Cachoeira do Couto (A3), Caverna Alambari de Baixo (A4), 
Fonte da Estrada (A5), Furnas (A6) e Fonte de Água Potável (A7). Doze (12) pontos foram coletados no Núcleo Caboclos (A8 a A19); 4 pontos no Núcleo Areado (A20 a A23); 4 pontos no Núcleo Bulhas D’Água (A24 a A28); 3 pontos no Núcleo Ouro Grosso (A29 a A31) e 5 pontos no Núcleo Santana (A32 a A36). As FIG. 17 a 19 apresentam imagens de algumas das colheitas realizadas na região do Alto Vale do Ribeira. No caso particular destes ensaios, por problemas de logística, as amostras de água foram coletadas utilizandose frascos de polietileno com $2 \mathrm{~L}$ de capacidade.

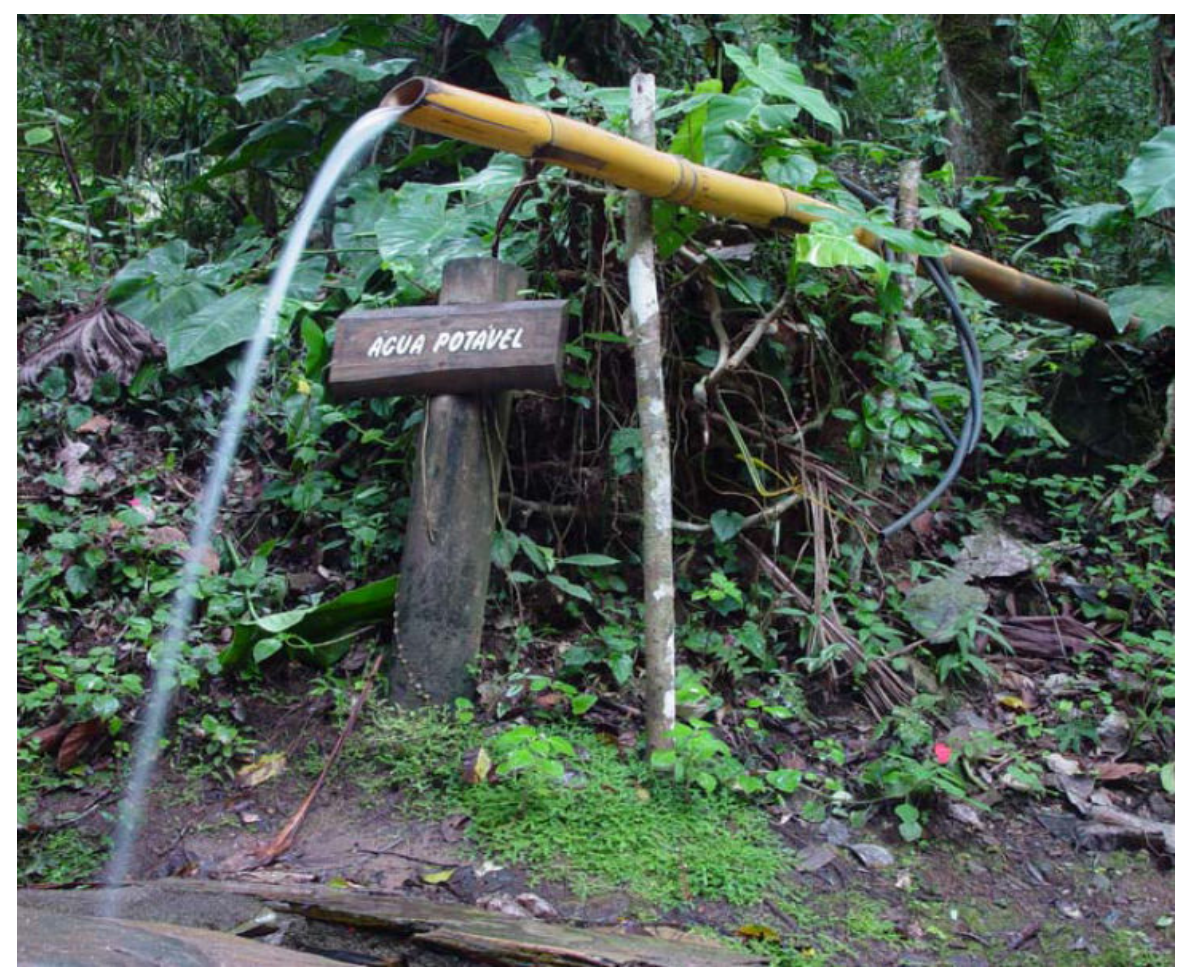

FIGURA 17 - Foto da amostragem de água em Iporanga (A7). 


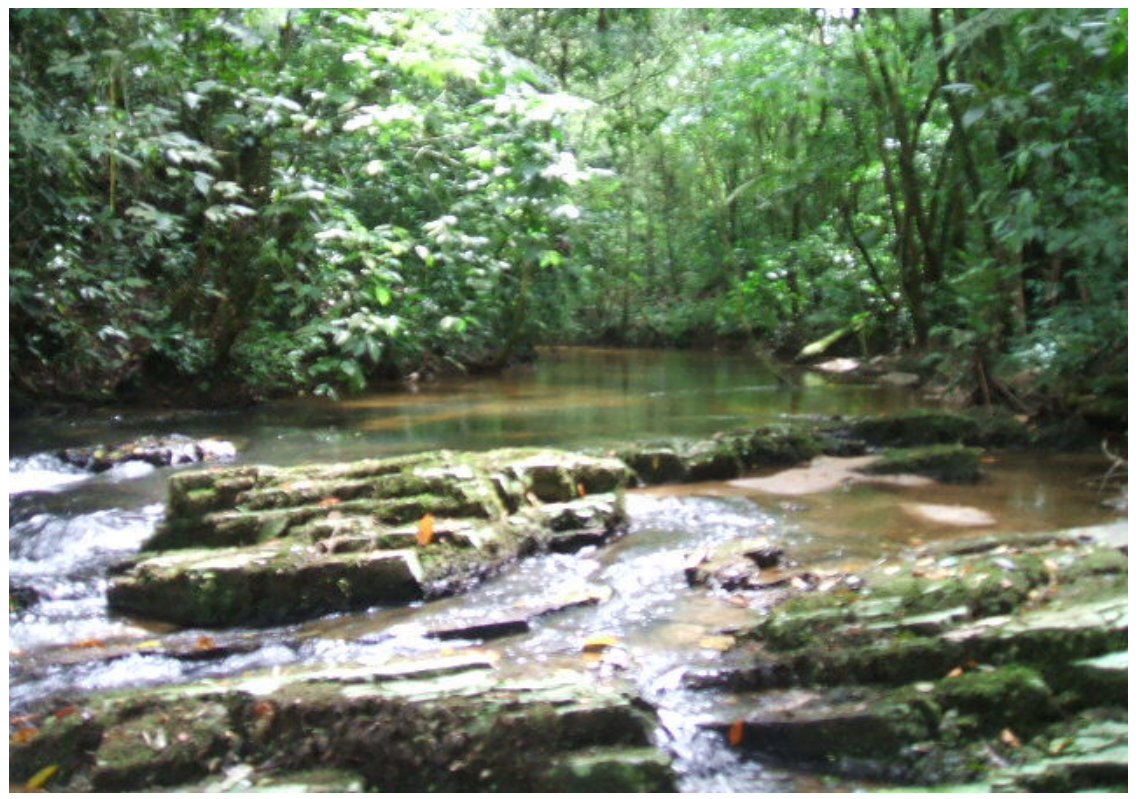

FIGURA 18 - Foto da amostragem de água no Núcleo Bulhas D'água (A24).

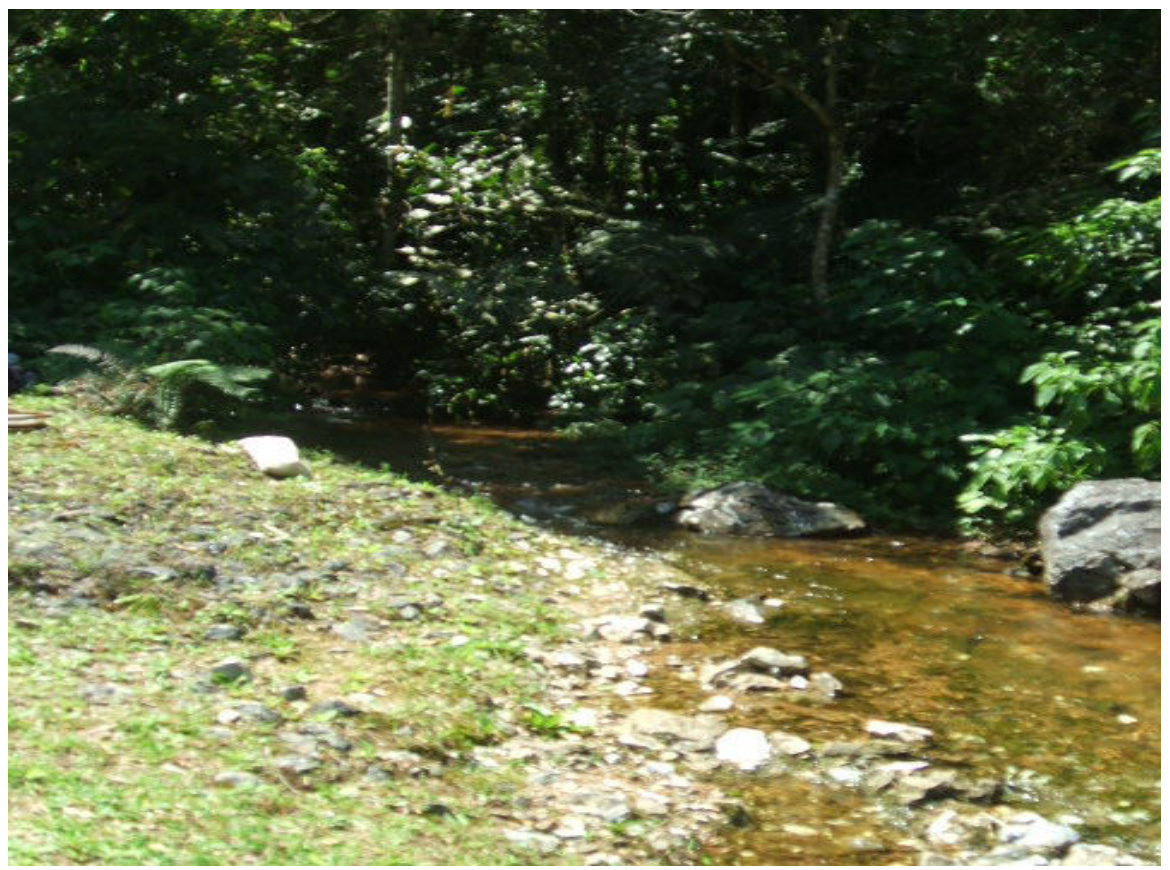

FIGURA 19 - Foto da amostragem de água do Núcleo Areado (A21).

Em todas as coletas foram registrados os dados das temperaturas do ar e da água, além da localização geográfica de cada estação com um GPS Garmin 12 canais (precisão \pm $3 \mathrm{~m}$ ). Logo após a coleta, as amostras foram transportadas para o Laboratório de Radiometria Ambiental do IPEN para a realização dos ensaios. 


\subsection{Determinação das concentrações do ${ }^{223} \operatorname{Ra} \mathrm{e}^{224} \mathrm{Ra}$ em amostras de água}

Os isótopos de Ra foram extraídos de cerca de 20 L das amostras de água subterrâneas e superficiais, pela sua pré-concentração em um trocador catiônico, preparado no laboratório, as fibras de acrílico impregnadas com dióxido de manganês. Este método tem sido amplamente empregado na extração de radionuclídeos naturais em amostras de água. As colunas de fibras de acrílico- $\mathrm{MnO}_{2}$ apresentam uma eficiência de extração relativamente alta para a remoção de $\mathrm{Th}, \mathrm{Pa}, \mathrm{Ra}$ e Ac, atingindo-se valores próximos a $100 \%$, se o volume percolado for elevado. A eficiência de extração das fibras de acrílico$\mathrm{MnO}_{2}$ pode ser verificada experimentalmente, conectando-se duas colunas em série, A e B, durante a etapa de percolação da amostra de água e determinando-se as atividades presentes nas mesmas no final do procedimento. A eficiência de extração (E) pode ser calculada pela seguinte relação:

$$
E=1-B / A
$$

A determinação dos isótopos ${ }^{223} \mathrm{Ra} \mathrm{e}^{224} \mathrm{Ra}$ foi realizada utilizando-se um sistema de coincidências atrasadas. O sistema foi desenvolvido por Rama \& Moore (1996), e baseiase na medida alfa dos isótopos de radônio, ${ }^{219} \mathrm{Rn}$ e ${ }^{220} \mathrm{Rn}$, e seus produtos de decaimento, que são arrastados para células de cintilação alfa com 1,1 L de volume, após a passagem de uma corrente de $\mathrm{He}$ gasoso por colunas contendo fibras de acrílico- $\mathrm{MnO}_{2}$, nas quais os isótopos de Ra foram inicialmente concentrados. As células de cintilação são feitas de frascos cilíndricos constituídos de um material denominado Plexiglass, no interior dos quais foi depositado sulfeto de zinco ativado com prata, $\mathrm{ZnS}$ (Ag). Estas células possuem na sua base uma janela de Plexiglass, transparente aos fótons produzidos pela interação das partículas alfa provenientes do decaimento dos isótopos de Rn com o material cintilador, que por sua vez se encontra oticamente acoplada a um tubo fotomultiplicador. As células de cintilação alfa são pintadas externamente, para refletir a luz e vedadas com fita adesiva preta. Dois tubos, um de entrada e um de saída de ar são posicionados no topo das células, e são conectados a um sistema de circulação de ar constituído por uma bomba de vácuo com diafragma (Cole Parmer) e um fluxômetro. Estas bombas mantém o fluxo de $\mathrm{He}(\mathrm{g})$ circulando no interior das células numa vazão de 5 a $7 \mathrm{~L} / \mathrm{min}$. Na vazão de $6 \mathrm{~L} / \mathrm{min}$, quase 
todos os eventos de decaimento do ${ }^{219} \mathrm{Rn}$ ocorrem instantâneamente no interior da célula de cintilação durante os primeiros instantes da ventilação. As concentrações de ${ }^{220} \mathrm{Rn}$ atingem o equilíbrio no interior das células após cerca de 5 minutos de ventilação. Os sinais recolhidos no tubo fotomultiplicador são dirigidos a um sistema de coincidências atrasadas. O sistema utiliza as diferenças nas constantes de decaimento dos isótopos de Po filhos do ${ }^{219} \mathrm{Rn}$ e do ${ }^{220} \mathrm{Rn}$. Qualquer partícula alfa detectada no interior das células produz um sinal que é encaminhado para um registrador das contagens totais, e para dois circuitos distintos que acumulam as contagens do ${ }^{219} \mathrm{Rn}$ e do ${ }^{220} \mathrm{Rn}$. No circuito de contagem do ${ }^{219} \mathrm{Rn}$, os sinais são atrasados $10 \mu$ s para permitir que o sistema se estabilize. O primeiro sinal gerado a partir deste momento aciona uma porta que permanece aberta durante 5,6 ms, cerca de 3 vezes o tempo de meia-vida do ${ }^{215}$ Po. Qualquer contagem detectada neste intervalo de tempo é registrada no canal do ${ }^{219} \mathrm{Rn}$, devido ao decaimento do ${ }^{215} \mathrm{Po}$. Todos os sinais são registrados também no canal do ${ }^{220} \mathrm{Rn}$. Neste canal um atraso de $10 \mathrm{~ms}$ é fixado, para permitir que nenhum sinal produzido pelo ${ }^{215} \mathrm{Po}$ (produto de decaimento do ${ }^{219} \mathrm{Rn}$ ) seja registrado. O circuito do ${ }^{220} \mathrm{Rn}$ permanece com a sua porta aberta por $600 \mathrm{~ms}, 4$ meiasvidas do ${ }^{216}$ Po.

$\mathrm{O}$ atraso estabelecido no canal do ${ }^{220} \mathrm{Rn}$ previne com eficácia o registro de sinais provenientes do decaimento ${ }^{219} \mathrm{Rn}-{ }^{215} \mathrm{Po}$. Entretanto, alguns sinais do decaimento ${ }^{220} \mathrm{Rn}$ ${ }^{216}$ Po podem ser detectados no canal do ${ }^{219} \mathrm{Rn}$, pois o tempo de 5,6 ms é suficiente para permitir que $2,5 \%$ dos eventos de decaimento do par ${ }^{220} \mathrm{Rn}-{ }^{216} \mathrm{Po}$ sejam detectados. Isto é continuamente corrigido pelo sistema, com as contagens de coincidência.

Logo após a percolação total das amostras de água nas colunas contendo fibras de acrílico- $\mathrm{MnO}_{2}$ (FIG. 20), as colunas impregnadas com $\mathrm{Ra}$ foram lavadas com água purificada Milli-Q para remover o excesso de sal e seqüencialmente, a umidade das mesmas foi reduzida para cerca de $20 \%$, com o auxílio de um jato de ar comprimido. 


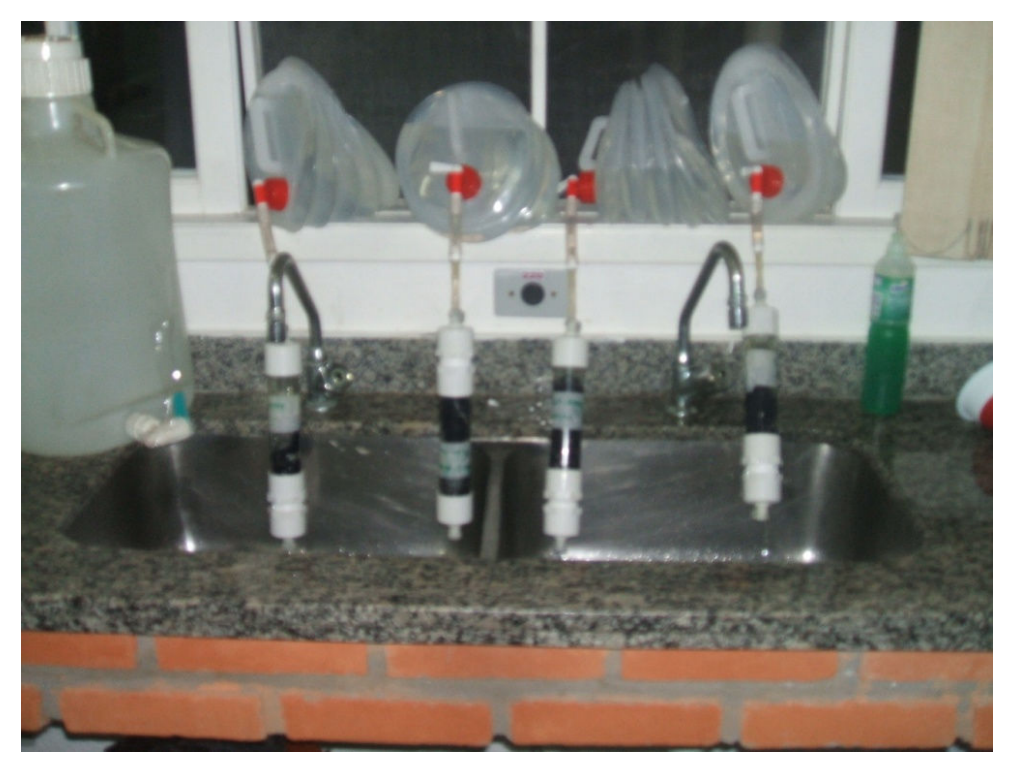

FIGURA 20 - Sistema de percolação para determinação dos isótopos naturais de Ra nas amostras de água.

Depois da secagem, as colunas contendo as fibras de acrílico- $\mathrm{MnO}_{2}$ foram conectadas ao sistema de coincidências atrasadas para a realização das medidas. Antes do início do registro das contagens, uma corrente de $6 \mathrm{~L} / \mathrm{min}$ de He de alta pureza foi passado através do sistema, arrastando os isótopos de radônio das colunas para as células de cintilação alfa. Cada amostra foi medida no sistema de coincidências atrasadas até que se obtivesse um total de 150 contagens para o ${ }^{219} \mathrm{Rn}$ e 300 contagens para o ${ }^{220} \mathrm{Rn}$.

Após as medidas de ${ }^{223} \mathrm{Ra}$ e de ${ }^{224} \mathrm{Ra}$, as amostras foram guardadas de 2 a 6 semanas para permitir o crescimento do ${ }^{224} \mathrm{Ra}$ em equilíbrio com o ${ }^{228} \mathrm{Th}$, que também pode ter sido ser adsorvido nas fibras de acrílico- $\mathrm{MnO}_{2}$ na ocasião da amostragem. Assim, amostras foram medidas mais uma vez, para que se pudesse determinar a atividade de ${ }^{224} \mathrm{Ra}$ suportada pelo ${ }^{228} \mathrm{Th}$ (segunda medida) e finalmente descontá-la da atividade de ${ }^{224} \mathrm{Ra}$ em excesso (primeira medida).

As eficiências de contagem foram determinadas pela medida de soluções de referência contendo atividades conhecidas de ${ }^{224} \mathrm{Ra}$ e de ${ }^{223} \mathrm{Ra}$ adsorvidas na colunas de fibras de acrílico- $\mathrm{MnO}_{2}$, mantendo-se a mesma geometria de contagem das amostras. Estes padrões foram preparados adsorvendo-se em fibras de acrílico- $\mathrm{MnO}_{2}$ concentrações exatamente conhecidas de ${ }^{232} \mathrm{Th}$ em equilíbrio com seus filhos $(\cong 300 \mathrm{mBq})$ e de ${ }^{227} \mathrm{Ac}(\cong$ $170 \mathrm{mBq}$ ) em equilíbrio com seus filhos. Contagens da radiação de fundo de cada sistema também foram realizadas por 30 minutos, antes das medidas dos padrões e das amostras. 


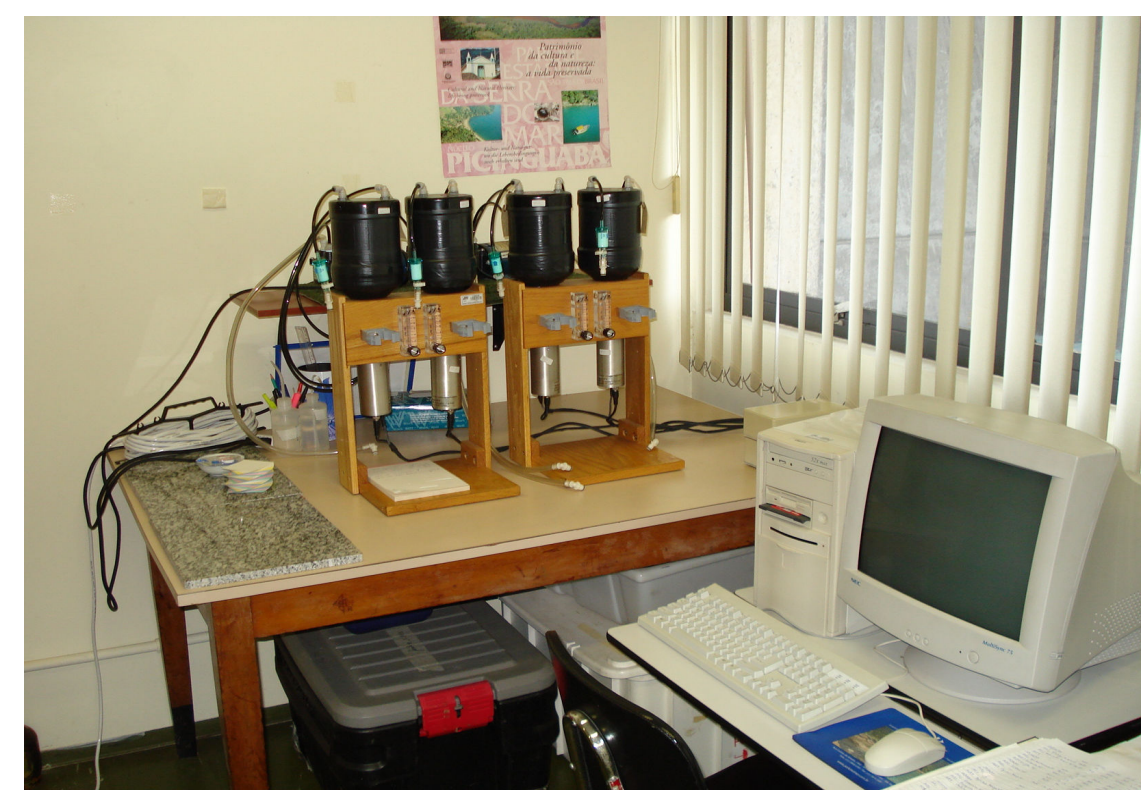

FIGURA 21 - Sistema de coincidência atrasadas, com células de cintilação de 1,1 L utilizadas para a determinação de ${ }^{223} \mathrm{Ra}$ e ${ }^{224} \mathrm{Ra}$ nas amostras de água de superfície e de água subterrâneas.

O sistema de coincidências atrasadas RaDeCCSys (FIG.21), possui um software que controla e registra todas as medidas obtidas (RaDeCC, Scientific Computer Instruments, 1999). Além disso, o programa contempla planilhas no Excel, nas quais as contagens totais, contagens nos canais ${ }^{219} \mathrm{Rn}$ e ${ }^{220} \mathrm{Rn}$, contagens de radiação de fundo, tempo de contagem, eficiências de contagem, data da medida, data da coleta e volume da amostra foram inseridas, sendo obtidas finalmente, as concentrações de atividade de ${ }^{223} \mathrm{Ra}$ $\mathrm{e}^{224} \mathrm{Ra}$, reportadas em unidades de mBq/ $100 \mathrm{~L}$. As equações de correção das chances de coincidência nos circuitos ${ }^{219} \mathrm{Rn}$ e ${ }^{220} \mathrm{Rn}$, assim como quaisquer outras características do circuito de coincidências atrasadas são referenciadas no artigo publicado pelos pesquisadores que patentearam o equipamento (Moore \& Arnold,1996).

\subsection{Determinação das concentrações $d{ }^{226} \operatorname{Ra~} e^{228} \operatorname{Ra}$ em amostras de água}

A determinação das concentrações de atividade de ${ }^{226} \mathrm{Ra}$ e ${ }^{226} \mathrm{Ra}$ nas amostras de água subterrânea e de superfície foi realizada pela contagem alfa e beta total, respectivamente, de um precipitado de $\mathrm{Ba}(\mathrm{Ra}) \mathrm{SO}_{4}$, em um detector proporcional de fluxo gasoso de baixa radiação de fundo, modelo Berthold LB 770 (FIG. 22). Esta técnica é vantajosa por apresentar uma baixa radiação de fundo e, conseqüentemente, um limite de 
detecção também muito baixo, aproximadamente $2,2 \mathrm{mBq} \mathrm{L} \mathrm{L}^{-1}$ para ${ }^{226} \mathrm{Ra}$ e $3,7 \mathrm{mBq} \mathrm{L}{ }^{-1}$ para ${ }^{228}$ Ra (Oliveira, 1998).

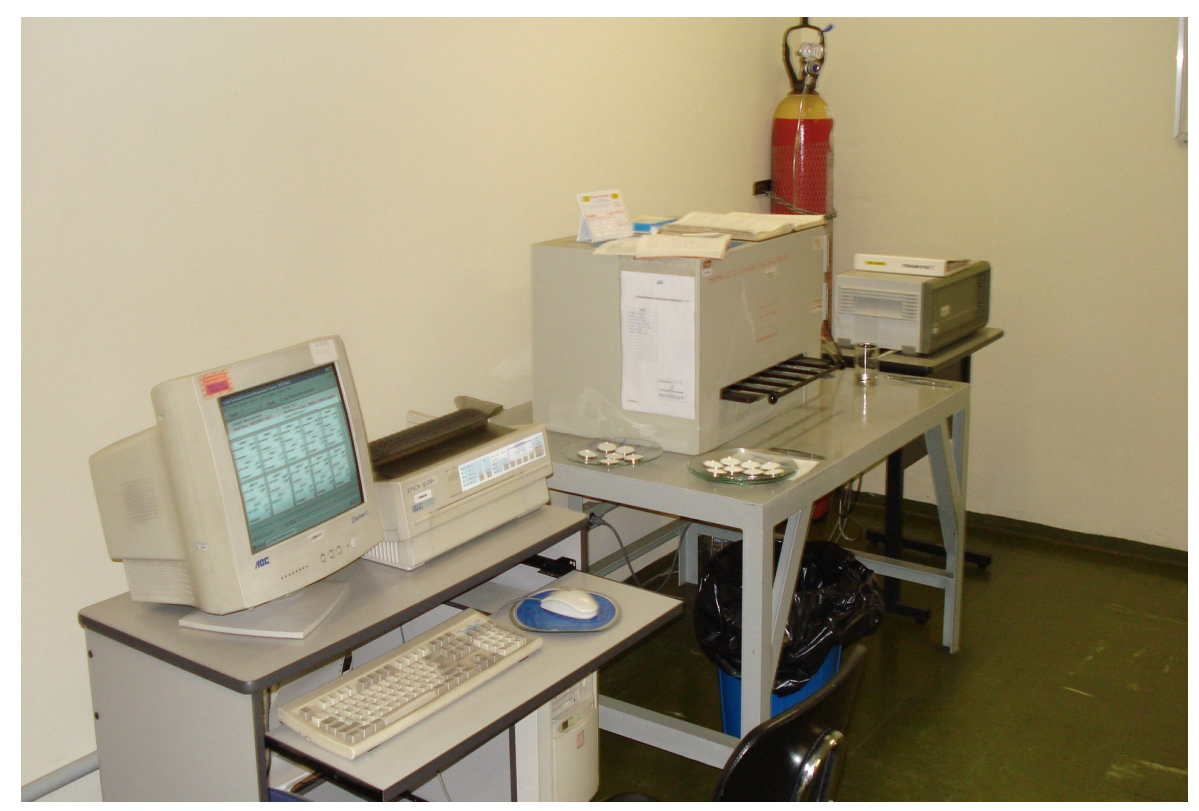

FIGURA 22 - Detector proporcional de fluxo gasoso, modelo Berthold LB 770.

Após a realização das medidas para a determinação das concentrações de atividade de ${ }^{223} \mathrm{Ra}$ e de $\mathrm{Ra}$, as fibras de acrílico- $\mathrm{MnO}_{2}$ foram lixiviadas com $200 \mathrm{~mL}$ de $\mathrm{HCl}$ concentrado, para remover quantitativamente os isótopos de Ra de meias-vidas longas. Ao filtrado obtido após a lixiviação, adicionou-se $5 \mathrm{~mL}$ de uma solução de cloridrato de hidroxilamina $40 \%$ para evitar a oxidação dos íons $\mathrm{Mn}^{2+}$ em solução, e a sua conseqüente precipitação como óxido hidratado nas etapas seguintes. $\mathrm{O}$ volume da solução foi diluído a $600 \mathrm{~mL}$ com água deionizada.

A seguir, adicionou-se à solução obtida anteriormente, $1 \mathrm{~mL}$ de uma solução de carregador de $\mathrm{Ba}^{2+}\left(20 \mathrm{mg} \mathrm{mL}^{-1}\right)$ e $1 \mathrm{~mL}$ de uma solução de carregador de $\mathrm{Pb}^{2+}(20 \mathrm{mg} \mathrm{mL}$ ${ }^{1}$ ). Os isótopos ${ }^{226} \mathrm{Ra} \mathrm{e}{ }^{228} \mathrm{Ra}$ foram determinados por co-precipitação com sulfato de bário na faixa de $\mathrm{pH}$ 4,5 - 5,0 em presença de EDTA, que forma complexo forte com o Ra, depois da separação de seus filhos por complexação com NTA na faixa de pH 12,5 - 13,0. $\mathrm{O}$ precipitado de $\mathrm{Ba}(\mathrm{Ra}) \mathrm{SO}_{4}$ formado foi filtrado à vácuo utilizando-se papel de filtro Millipore AP20 004700. Determinou-se o rendimento químico por gravimetria, pela pesagem do precipitado formado a partir da adição da solução de carregador de $\mathrm{Ba}^{2+}(20$ $\mathrm{mg} /$ amostra). $\mathrm{O}{ }^{226} \mathrm{Ra}$ e o ${ }^{228} \mathrm{Ra}$ foram medidos após 21 dias da precipitação, tempo este necessário para que ${ }^{226} \mathrm{Ra}$ entrasse em equilíbrio com seus filhos e para que as 
contribuições dos outros isótopos de Ra emissores alfa, ${ }^{223} \mathrm{Ra}$ e ${ }^{224} \mathrm{Ra}$ fossem nulas. Este intervalo de tempo foi suficiente para que o equilíbrio ${ }^{228} \mathrm{Ra} /{ }^{228} \mathrm{Ac}$ fosse igualmente atingido. A incerteza da determinação dos isótopos de Ra de meias-vidas longas foi inferior a $7 \%$.

A concentração de atividade de ${ }^{226} \mathrm{Ra}$ foi obtida a partir da seguinte expressão:

$$
A(R a-226)=\frac{R n-B g}{60 \cdot R Q \cdot E F \alpha \cdot f a b s \cdot\left[1+k\left(1-e^{-\lambda t}\right)\right] \cdot Q}
$$

Onde:

$\mathrm{A}\left({ }^{226} \mathrm{Ra}\right)=$ atividade de ${ }^{226} \mathrm{Ra}, \mathrm{em} \mathrm{Bq} / \mathrm{L}$.

$\mathrm{Rn}=$ taxa de contagem alfa total da amostra (cpm).

$\mathrm{Bg}=$ taxa de contagem da radiação de fundo alfa total $(\mathrm{cpm})$.

$\mathrm{RQ}=$ rendimento químico gravimétrico percentual (\%).

$\mathrm{EF} \alpha=$ eficiência de contagem alfa total, calculada pelo ${ }^{241} \mathrm{Am}$ (cps/dps).

$\mathrm{Q}=$ quantidade de amostra (L).

fabs $=$ coeficiente de auto-absorção do ${ }^{226} \mathrm{Ra}$ no precipitado de $\mathrm{Ba}(\mathrm{Ra}) \mathrm{SO}_{4}$.

$\lambda^{222} \mathrm{Rn}=0,181 \mathrm{~d}^{-1}$.

$\mathrm{t}=$ tempo desde a precipitação até a contagem (d).

$\mathrm{k}=$ constante que leva em conta a diferença entre os coeficientes de auto-absorção das 4 partículas alfa que são emitidas no decaimento do ${ }^{226} \mathrm{Ra}$ e que tem as energias: ${ }^{226} \mathrm{Ra}(4,8$ $\mathrm{MeV}),{ }^{222} \mathrm{Rn}(5,5 \mathrm{MeV}),{ }^{218} \mathrm{Po}(6,0 \mathrm{MeV}) \mathrm{e}{ }^{214} \mathrm{Po}(7,7 \mathrm{MeV})$.

$$
k=\frac{f a b s(R n-222)+f a b s(P o-218)+f a b s(P o-214)}{f a b s(R a-226)}
$$


A expressão que forneceu a concentração de atividade de ${ }^{228} \mathrm{Ra}$ a partir da medida beta total foi:

$$
A(R a-228)=\frac{R n-B g}{60 \cdot R Q \cdot E F \beta(R a-228) \cdot Q}-\frac{E F \beta(R a-226) \cdot A(R a-226)}{E F \beta(R a-228)}
$$

Onde:

$\mathrm{A}\left({ }^{228} \mathrm{Ra}\right)=$ atividade do ${ }^{228} \mathrm{Ra}, \mathrm{em} \mathrm{Bq} / \mathrm{L}$.

$\mathrm{Rn}=$ taxa de contagem beta total obtida $(\mathrm{cpm})$.

$\mathrm{Bg}=$ taxa de contagem da radiação de fundo beta total $(\mathrm{cpm})$.

$\mathrm{RQ}=$ rendimento químico gravimétrico percentual (\%).

$\mathrm{EF} \beta\left({ }^{228} \mathrm{Ra}\right)=$ eficiência de contagem beta total, calculada pela medida de um precipitado padrão de $\mathrm{Ba}\left({ }^{228} \mathrm{Ra}\right) \mathrm{SO}_{4}(\mathrm{cps} / \mathrm{dps})$.

$\mathrm{EF} \beta\left({ }^{226} \mathrm{Ra}\right)=$ eficiência de contagem beta total, calculada pela medida de um precipitado padrão de $\mathrm{Ba}\left({ }^{226} \mathrm{Ra}\right) \mathrm{SO}_{4}$ (cps/dps).

$\mathrm{A}\left({ }^{226} \mathrm{Ra}\right)=$ atividade calculada para ${ }^{226} \mathrm{Ra}, \mathrm{em} \mathrm{Bq} / \mathrm{L}$.

$\mathrm{Q}=$ quantidade de amostra $(\mathrm{L})$.

\subsection{Determinação da eficiência de contagem alfa total para medida de ${ }^{226} \mathrm{Ra}$}

A calibração do detector proporcional de fluxo gasoso com a finalidade de determinar a eficiência para a medida alfa total de amostras de $\mathrm{Ba}\left({ }^{226} \mathrm{Ra}^{2} \mathrm{SO}_{4}\right.$ foi feita utilizando-se um padrão de referência de ${ }^{241} \mathrm{Am}$, geralmente uma amostra eletrodepositada em disco de níquel com dimensões conhecidas. Estas fontes especialmente preparadas contêm aproximadamente $500 \mathrm{pCi}(18,5 \mathrm{~Bq})$ do isótopo ${ }^{241} \mathrm{Am}\left(\mathrm{T}_{1 / 2}=432,6\right.$ anos), sendo esta atividade suficiente para proporcionar uma taxa de contagem razoável em um tempo de medida relativamente curto.

O sistema de contagem empregado nas medidas, o detector proporcional Berthold LB, possui 10 detectores circulares (geometria $2 \pi$; diâmetro de 2 polegadas) que foram calibrados simultaneamente. Para tanto, foram preparados três padrões de ${ }^{241} \mathrm{Am}$ eletrodepositados com atividades muito próximas $\mathrm{P}_{1}(11,86 \pm 0,38 \mathrm{~Bq}), \mathrm{P}_{2}(8,21 \pm 0,31$ $\mathrm{Bq})$ e $\mathrm{P}_{3}(15,59 \pm 0,50 \mathrm{~Bq})$ que foram contados em cada detector. Desta forma, a eficiência foi determinada utilizando-se a expressão: 


$$
E F \alpha\left({ }^{226} R a\right)=\frac{R n-B g}{A_{\text {corr }}\left({ }^{241} A m\right) \cdot 60 \cdot R Q}
$$

Em que:

$\mathrm{EF} \alpha\left({ }^{226} \mathrm{Ra}\right)=$ eficiência de contagem alfa para a medida de ${ }^{226} \mathrm{Ra}$, calculada pelo padrão de ${ }^{241} \mathrm{Am}(\mathrm{cps} / \mathrm{dps})$.

$\mathrm{Rn}=$ taxa de contagem alfa medida (cpm).

$\mathrm{Bg}=$ background alfa do detector (cpm).

$\mathrm{A}_{\text {corr }}\left({ }^{241} \mathrm{Am}\right)=$ atividade da fonte de Am corrigida para a data medida, em Bq.

$\mathrm{RQ}=$ rendimento químico percentual da eletrodeposição do padrão de ${ }^{241} \mathrm{Am}(\%)$.

Os padrões $\mathrm{P}_{1}, \mathrm{P}_{2}$ e $\mathrm{P}_{3}$ foram contados em cada detector, tendo sido realizadas no total 30 medidas. $O$ tempo de medida definido para a contagem alfa foi de 200 minutos e a tensão de operação do detector foi de $1.650 \mathrm{~V}$. Destas medidas, obteve-se finalmente uma eficiência alfa média para cada um dos detectores.

\subsection{Determinação da eficiência de contagem beta total para medida de ${ }^{226} \operatorname{Ra}$ e de ${ }^{228} \mathbf{R a}$}

$\mathrm{Na}$ voltagem de operação em que foram realizadas as medidas beta total $(1.650 \mathrm{~V})$, as partículas alfa e beta emitidas pelo ${ }^{226} \mathrm{Ra}$ e seus descendentes, são detectadas juntamente com as partículas beta emitidas pelo ${ }^{228} \mathrm{Ac}(1,2 \mathrm{MeV} ; 2,1 \mathrm{MeV})$. Deste modo, obtém-se uma taxa de contagem beta total relativa à ${ }^{226} \mathrm{Ra}$ e filhos e ${ }^{228} \mathrm{Ac}$, fazendo-se necessário determinar uma eficiência de contagem beta para ${ }^{226} \mathrm{Ra}$ e descendentes nesta voltagem de operação, com a finalidade de discriminar posteriormente, o quanto este isótopo contribui para a taxa de contagem beta total obtida na medida.

A eficiência beta para ${ }^{226} \mathrm{Ra}$ foi determinada a partir da medida beta total de amostras de $\mathrm{Ba}(\mathrm{Ra}) \mathrm{SO}_{4}$ obtidas com a adição de um padrão de ${ }^{226} \mathrm{Ra}$. Na medida, colocouse sobre a amostra uma folha de papel de filtro quantitativo Whatman 50, que teve por objetivo barrar as partículas beta de baixa energia do ${ }^{228} \mathrm{Ra}(40 \mathrm{keV})$. A eficiência beta para ${ }^{226} \mathrm{Ra}$ foi determinada pela expressão: 


$$
E F \beta\left({ }^{226} R a\right)=\frac{R n-B g}{A_{\text {corr }}\left({ }^{226} R a\right) \cdot 60 \cdot R Q}
$$

Onde:

$\operatorname{EF} \beta\left({ }^{226} \mathrm{Ra}\right)=$ eficiência de contagem beta total para ${ }^{226} \mathrm{Ra}\left(\operatorname{cps~dps}{ }^{-1}\right)$.

$\mathrm{Rn}=$ taxa de contagem beta total obtida (cpm).

$\mathrm{Bg}=$ background beta do detector (cpm).

$\mathrm{A}_{\text {corr }}\left({ }^{226} \mathrm{Ra}\right)=$ atividade do padrão de ${ }^{226} \mathrm{Ra}$ corrigida para a data da medida $(\mathrm{Bq})$.

$\mathrm{RQ}=$ rendimento químico percentual $(\%)$.

Para fins de calibração, foram preparadas 3 amostras de $\mathrm{Ba}\left({ }^{226} \mathrm{Ra}\right) \mathrm{SO}_{4}$ com atividades de cerca de $200 \mathrm{mBq}$, realizando-se medidas em cada detector. O tempo de medida definido para a contagem beta foi de 200 minutos. Destas medidas, obteve-se uma eficiência beta média para o ${ }^{226} \mathrm{Ra}$ para cada detector.

\subsection{Determinação da eficiência de contagem beta de ${ }^{228} \mathrm{Ra}$}

A eficiência beta para ${ }^{228} \mathrm{Ra}$ foi determinada pela medida total de amostras de $\mathrm{Ba}(\mathrm{Ra}) \mathrm{SO}_{4}$ obtidas com a adição de um padrão de ${ }^{228} \mathrm{Ra}$. Durante a medida o precipitado foi coberto com uma folha de papel de filtro quantitativo Whatman 50, para barrar as partículas beta de baixa energia do ${ }^{228} \mathrm{Ra}$, sendo somente as partículas beta emitidas pelo ${ }^{228}$ Ac que estava em equilíbrio com o precursor. A expressão que forneceu a eficiência beta para o ${ }^{228} \mathrm{Ra}$ foi:

$$
E F \beta\left({ }^{228} R a\right)=\frac{R n-B g}{A_{\text {corr }}\left({ }^{228} R a\right) \cdot 60 \cdot R Q}
$$

Onde:

$\mathrm{EF} \square\left({ }^{228} \mathrm{Ra}\right)=$ eficiência de contagem beta total para ${ }^{228} \mathrm{Ra}\left(\operatorname{cps~dps}^{-1}\right)$.

$\mathrm{Bg}=$ background beta $(\mathrm{cpm})$.

$\mathrm{A}_{\text {corr }}(\mathrm{Ra})=$ atividade do padrão de Ra corrigida para a data da medida $(\mathrm{Bq})$.

$\mathrm{RQ}=$ rendimento químico percentual (\%). 
Para a calibração foram preparadas 3 amostras de $\mathrm{Ba}(\mathrm{Ra}) \mathrm{SO}_{4}$, obtidas de acordo com o procedimento descrito anteriormente, com a adição de cerca de $200 \mathrm{mBq}$ por amostra de um padrão de ${ }^{228} \mathrm{Ra}$. O tempo de medida beta total foi de 200 minutos e a tensão de operação do detector foi de $1.650 \mathrm{~V}$. Em cada um dos detectores foram realizadas 3 medidas e a partir destas, determinou-se a eficiência beta média para ${ }^{228} \mathrm{Ra}$ de cada detector.

\subsection{Determinações dos parâmetros físicos e das concentrações de salinidade e nutrientes dissolvidos nas amostras}

As amostras de água subterrânea e de água de superfície destinadas à determinação das concentrações dos nutrientes dissolvidos principais (nitrito, nitrato, fosfato, silicato e amônio), $\mathrm{pH}$, salinidade, material particulado em suspensão e matéria orgânica foram coletadas e encaminhadas para análise no Laboratório de nutrientes, micronutrientes e traços no oceano - LABNUT (1OUSP).

\subsubsection{Potencial Hidrogeniônico (pH)}

As medidas de $\mathrm{pH}$ foram realizadas utilizando-se um pHmetro modelo PHM 203 da Radiometer, com eletrodo de vidro combinado e sensor de temperatura. $\mathrm{O}$ valor $\mathrm{pH}$ obtido é corrigido em função da diferença de temperatura da amostra in situ e do laboratório, segundo a metodologia de Aminot \& Chaussepied (1983). O método apresenta precisão de $\pm 0,002$.

\subsubsection{Salinidade}

Salinidade é a medida da quantidade de sais presentes numa amostra de água. A unidade pode ser apresentada em grama de sais por quilograma água $\left(\mathrm{g} \mathrm{kg}^{-1}\right)$ ou \%o (por mil), ou sem unidade. Esta última trata da determinação da salinidade por meio da condutividade, que emprega a razão entre a condutividade obtida para a mostra e um padrão, levando a um resultado dimensional, ou seja, está diretamente relacionada com a concentração de íons em solução (Campos, 2010).

Existem salinômetros comerciais que avaliam a razão a condutividade da amostra de salinidade desconhecida e o padrão da água do mar. A condutividade elétrica de uma 
solução é determinada por meio de circuito elétrico, no qual a resistência da célula contendo eletrólito é comparada com a resistência de uma solução padrão. A resistência é expressa em Ohm e a condutividade é dada em Siemens por metro $\left(\mathrm{S} \mathrm{m}^{-1}\right)$

Neste trabalho, as salinidades foram determinadas a partir de um salinômetro indutivo de marca Beckman - RS-10 (Grasshoff et al, 1983).

\subsubsection{Nitrito dissolvido}

Todos os métodos para a determinação fotométrica do nitrito em água do mar estão baseados na reação do nitrito com uma amina aromática, a sulfanilamida (AS), em meio ácido formando o íon diazônico. Este reage com uma segunda amina aromática formando um composto colorido, o diazo, cuja quantidade formada á proporcional à concentração de nitrito presente na amostra analisada.

A avaliação do teor de nitrito nas amostras baseia-se no método descrito em Treguer \& Le Corre (1975) utilizando-se o aparelho automático Technicon Auto-Analyzer II. A precisão do método utilizado foi de $0,02 \%$.

\subsubsection{Nitrato dissolvido}

Existem diversos métodos para a análise do nitrato dissolvido como a polarografía, a eletrólise e outros. O melhor método para trabalhar com água do mar é o que está baseado na redução do nitrato à nitrito e a conseqüente formação do composto diazo, prosseguindo a análise para a determinação do nitrito, obtendo-se assim, o valor do nitrito total que por subtração do valor de nitrito inicial, antes da redução, fornece o valor de nitrato. A redução é feita com a utilização de uma coluna de cádmio cuperizado.

O nitrato prevalece como íon na água do mar. A redução do nitrato à nitrito ocorre com a utilização de um redutor de cádmio cuperizado sob condições ajustadas, aonde o nitrato passa a ser quantitativamente convertido à nitrito.

$$
\mathrm{NO}_{3}{ }^{-}+\mathrm{Me}(\mathrm{s})+2 \mathrm{H}^{+} \rightarrow \mathrm{NO}_{2}^{-}+\mathrm{Me}^{++}+\mathrm{H}_{2} \mathrm{O}
$$


A eficiência da redução do nitrato a nitrito depende do metal utilizado, do $\mathrm{pH}$ da solução e da atividade da superfície a do metal. Uma reação, em solução alcalina, ou com um metal cuja superfície esteja inativa não reduz de modo eficiente o nitrato. Soluções muito ácidas ou com metal altamente eletronegativo, ou com superfície muito ativa, resultam em redução além do estágio nitrito. Em ambos os casos, a análise resultaria em baixos valores de nitrato.

Para a determinação de nitrato, as amostras foram processadas segundo o método descrito por Treguer \& Le Corre (1975), com modificações descritas em Braga (2002), utilizando-se o equipamento automático Technicon Auto-Analyzer II. Por diferença do valor obtido na análise de nitrito, temos o valor real da concentração de nitrato. A precisão do método utilizado foi de $0,1 \%$.

\subsubsection{Silicato dissolvido}

O silício é encontrado na água do mar sob a forma de silício dissolvido e também sob a forma particulada. Provavelmente, a principal forma dissolvida seja o ácido silícico: $\mathrm{HSi}(\mathrm{OH})_{4}$. O silício particulado é proveniente de estruturas extra-celulares das diatomáceas, silicoflagelados e radiolários vivos e mortos, sendo então chamado de silício particulado biogênico. O silício inorgânico é encontrado sob várias formas minerais como quartzos, feldspatos e na constituição de minerais argilosos e é chamado de silício nãobiogênico. Grande parte do silício que atinge o mar é transportado pelas águas dos rios, pela atmosfera, pela erosão de rochas e pelos sedimentos oceânicos.

A determinação dos compostos de silício dissolvidos encontradas em águas naturais baseia-se na formação de um complexo amarelo, o ácido silicomolibdico após o tratamento da amostra com molibdato. Foram desenvolvidos alguns métodos para transformar o complexo de cor amarelada em um complexo azul mais intenso. Muitos métodos utilizam redutores orgânicos para a redução deste heteropoliácido. $O$ método descrito foi apresentado por Grasshoff al. (1983), utilizando como redutor o ácido ascórbico. O ácido oxálico também pode ser utilizado pelas seguintes razões: 1) para reduzir o excesso de molibdato presente, 2) para reduzir a influência do fosfato presente na amostra. 
O método empregado para análise do silicato foi descrito por Grasshoff et al. (1983). A determinação do silicato foi realizada em um espectrofotômetro digital Gênesis II, da marca Bausch \& Lomb. A precisão do método utilizado foi de 0,2 \%.

\subsubsection{Fosfato dissolvido}

O fósforo, bem como o nitrogênio, é um constituinte da matéria orgânica viva e como tal, ele apresenta um ciclo onde pode estar presente sob formas orgânicas e inorgânicas. De um modo geral, o fósforo encontra-se no meio marinho sob a forma de compostos orgânicos em suspensão ou em solução, sob a forma de fosfatos inorgânicos insolúveis (tais como fosfato de cálcio e de ferro) ou sob a forma de fosfatos solúveis,

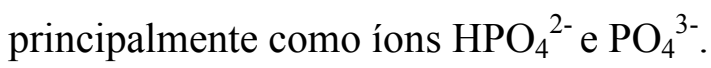

A maioria dos métodos de determinação do fosfato na água do mar baseia-se na reação desses íons com um reagente contendo molibdato, em meio ácido, produzindo um complexo: o fosfomolibdato. Neste método, ocorre uma reação quantitativa do fosfato com os íons molibdato, catalisada pelo antimônio, formando inicialmente um complexo amarelado que é reduzido a um composto azul, por ação do ácido ascórbico.

A avaliação do fosfato baseia-se no procedimento descrito por Grasshoff et al.(1983). As análises do fosfato foram feitas utilizando-se o espectrofotômetro digital Gênesis 11, da marca Bausch \& Lomb. A precisão do método utilizado foi de $0,02 \%$.

\subsubsection{Amônio dissolvido}

As amostras foram retiradas diretamente da garrafa, sendo os reagentes adicionados durante a coleta. As amostras foram armazenadas ao abrigo da luz. A metodologia utilizada é a descrita por Tréguer \& Le Corre (1975), apresentando uma precisão de $\pm 0,05$ $\mu \mathrm{M}$-N-amoniacal. 


\subsubsection{Material em Suspensão - MES}

A metodologia usada para a determinação da matéria em suspensão foi segundo Strickland \& Parsons (1968), onde cerca de 450 a $600 \mathrm{~mL}$ das amostras foram filtradas em papel de filtro de porosidade nominal de 0,45 $\mu \mathrm{m}$ de fibras de vidro GF/F Whatman, previamente lavados com água destilada, calcinados em uma mufla por $270 \mathrm{~min}$ a $450^{\circ} \mathrm{C}$, e por último pesados em uma balança analítica. Após a filtragem das amostras, os papéis de filtro foram congelados a $-20^{\circ} \mathrm{C}$, para análises posteriores.

Os filtros congelados foram secados em estufa a $60{ }^{\circ} \mathrm{C}$ durante 1 hora, esfriados e em seguida foram pesados. A diferença do peso antes e depois da filtragem da amostra indica a quantidade de matéria em suspensão presente. A unidade utilizada foi de $\mathrm{mgL}^{-1}$.

\subsubsection{Matéria Orgânica em Suspensão - MO}

Para determinação da matéria em suspensão, foram utilizados os mesmos papéis de filtro da determinação MES. Os filtros foram calcinados por $270 \mathrm{~min}$ a $450^{\circ} \mathrm{C}$, a fim de eliminar a matéria orgânica presente, e em seguida foram pesados em uma balança analítica. A diferença de peso do papel de filtro antes da calcinação e depois, indica a quantidade de matéria orgânica em suspensão presente no volume filtrado das amostras, em $\mathrm{mgL}^{-1}$ e $\%$. 


\section{CAPÍTULO 6. RESULTADOS}

Para este trabalho, realizou-se a calibração do detector proporcional de fluxo gasoso de baixa radiação de fundo marca Berthold, modelo LB 770, utilizando-se soluções de referência de ${ }^{226} \mathrm{Ra} \mathrm{e}^{228} \mathrm{Ra}$ e construindo-se uma curva de crescimento para ${ }^{226} \mathrm{Ra}$ e filhos, conforme descrito na parte experimental. As eficiências de contagem alfa total para a determinação de ${ }^{226} \mathrm{Ra}$, assim como as eficiências beta total para os filhos do ${ }^{226} \mathrm{Ra}$ e para o ${ }^{228} \mathrm{Ra}$ obtidas no detector proporcional de fluxo gasoso de baixa radiação de fundo Berthold LB 770 são apresentadas na TAB. 3.

TABELA 3 - Eficiências médias aritméticas e respectivos desvios padrão da contagem alfa total para a determinação de ${ }^{226} \mathrm{Ra}$, beta total para os filhos do ${ }^{226} \mathrm{Ra}$ e beta total para o ${ }^{228} \mathrm{Ra}$, determinadas no detector proporcional de fluxo gasoso Berthold LB 770 .

\begin{tabular}{cccc}
\hline Detector & $\begin{array}{c}\mathbf{E F \alpha}{ }^{226} \mathbf{R a} \\
(\mathbf{c p s} / \mathbf{d p s})\end{array}$ & $\begin{array}{c}\mathbf{E F \beta}{ }^{226} \mathbf{R a} \\
(\mathbf{c p s} / \mathbf{d p s})\end{array}$ & $\begin{array}{c}\mathbf{E F \beta}{ }^{228} \mathbf{R a} \\
(\mathbf{c p s} / \mathbf{d p s})\end{array}$ \\
\hline 1 & $0,2658 \pm 0,0133$ & $0,6935 \pm 0,0347$ & $0,4100 \pm 0,0205$ \\
2 & $0,2796 \pm 0,0139$ & $0,7065 \pm 0,0353$ & $0,4199 \pm 0,0210$ \\
3 & $0,2833 \pm 0,0142$ & $0,7054 \pm 0,0353$ & $0,4251 \pm 0,0213$ \\
4 & $0,2701 \pm 0,0135$ & $0,7022 \pm 0,0351$ & $0,4252 \pm 0,0213$ \\
5 & $0,2701 \pm 0,0135$ & $0,6987 \pm 0,0349$ & $0,4138 \pm 0,0207$ \\
6 & $0,2796 \pm 0,0139$ & $0,7015 \pm 0,0351$ & $0,4184 \pm 0,0209$ \\
7 & $0,2854 \pm 0,0143$ & $0,7045 \pm 0,0352$ & $0,4391 \pm 0,0219$ \\
8 & $0,2902 \pm 0,0145$ & $0,7044 \pm 0,0352$ & $0,4446 \pm 0,0222$ \\
9 & $0,2897 \pm 0,0145$ & $0,7089 \pm 0,0355$ & $0,4337 \pm 0,0217$ \\
10 & $0,2782 \pm 0,0139$ & $0,6942 \pm 0,0347$ & $0,4219 \pm 0,0211$ \\
\hline
\end{tabular}

Nas TAB. 4 a 29 são apresentadas as coordenadas geográficas dos pontos de amostragem, as concentrações de atividade de ${ }^{226} \mathrm{Ra},{ }^{228} \mathrm{Ra}$, razões de atividade ${ }^{228} \mathrm{Ra} /{ }^{226} \mathrm{Ra}$, valores de salinidade, temperatura, $\mathrm{pH}$ e as concentrações dos nutrientes principais: nitrito, nitrato, fosfato, silicato e amônio. Além disso, como em ambientes fluviais e estuarinos a concentração de Ra pode ser influenciada pela quantidade de material particulado em suspensão, nestas tabelas também são apresentados os valores de MES (material em suspensão) e MO (matéria orgânica em suspensão). 
TABELA 4 - Coordenadas geográficas das amostras das estações hidroquímicas do sistema estuarino Cananéia-Iguape (Fevereiro/ 2009).

\begin{tabular}{|c|c|c|c|c|c|c|c|c|c|c|c|}
\hline Amostras & $\begin{array}{c}\text { Profundidade } \\
\text { (m) }\end{array}$ & $\begin{array}{c}\text { Data da } \\
\text { coleta }\end{array}$ & $\begin{array}{c}\text { Volume } \\
\text { (L) }\end{array}$ & $\begin{array}{c}\mathrm{T} \\
\left({ }^{\circ} \mathrm{C}\right)\end{array}$ & Latitude & Longitude & Salinidade & pH & $\begin{array}{c}\text { MES } \\
(\mathrm{mg} / \mathrm{L})\end{array}$ & $\begin{array}{c}\text { MO } \\
(\mathrm{mg} / \mathrm{L})\end{array}$ & $\begin{array}{c}\text { MO } \\
\%\end{array}$ \\
\hline Estação CAN 1A & 0 & $10 / 02 / 2009$ & 10 & 26,0 & $25^{\circ} 03.351^{\prime} \mathrm{S}$ & $47^{\circ} 54.944^{\prime} \mathrm{W}$ & 31,60 & 8,361 & 911,0 & 855,2 & 93,9 \\
\hline Estação CAN 2A & 0 & $10 / 02 / 2009$ & 10 & 28,6 & $25^{\circ} 02.908^{\prime} \mathrm{S}$ & $47^{\circ} 54.895^{\prime} \mathrm{W}$ & 20,08 & 7,999 & 955,2 & 915,2 & 95,8 \\
\hline Estação CAN 3A & 0 & $10 / 02 / 2009$ & 10 & 28,0 & $25^{\circ} 01.084^{\prime} \mathrm{S}$ & $47^{\circ} 55.548^{\prime} \mathrm{W}$ & 19,59 & 8,132 & 1009,4 & 971,6 & 96,3 \\
\hline Estação CAN 4A & 0 & $10 / 02 / 2009$ & 10 & 27,8 & $25^{\circ} 01.467^{\prime} \mathrm{S}$ & $47^{\circ} 55.308^{\prime} \mathrm{W}$ & 24,03 & 8,263 & 372,2 & 337,8 & 90,8 \\
\hline Estação IG 6A & 0 & $12 / 02 / 2009$ & 10 & 29,0 & $24^{\circ} 54.166^{\prime} \mathrm{S}$ & $47^{\circ} 48.520^{\prime} \mathrm{W}$ & 7,78 & 7,278 & 2,4 & - & - \\
\hline Estação IG 6B & 5 & $12 / 02 / 2009$ & 10 & 29,0 & $24^{\circ} 54.166^{\prime} \mathrm{S}$ & $47^{\circ} 48.520^{\prime} \mathrm{W}$ & 7,25 & 7,344 & 604,0 & 567,5 & 94,0 \\
\hline Estação IG 7A & 0 & $12 / 02 / 2009$ & 10 & 27,0 & $24^{\circ} 44.505^{\prime} \mathrm{S}$ & $47^{\circ} 35.952^{\prime} \mathrm{W}$ & 0,07 & 7,041 & 59,4 & 8,9 & 14,9 \\
\hline Estação IG 7B & 5 & $12 / 02 / 2009$ & 10 & 27,0 & $24^{\circ} 44.505^{\prime} \mathrm{S}$ & $47^{\circ} 35.952^{\prime} \mathrm{W}$ & 0,06 & 6,963 & 165,3 & 24,3 & 14,7 \\
\hline Estação IG 8A & 0 & $12 / 02 / 2009$ & 10 & 27,0 & $24^{\circ} 43.940^{\prime} \mathrm{S}$ & $47^{\circ} 34.811^{\prime} \mathrm{W}$ & 0,03 & 6,818 & 33,7 & 8,0 & 23,8 \\
\hline Estação IG 8B & 3 & $12 / 02 / 2009$ & 10 & 27,0 & $24^{\circ} 43.940^{\prime} \mathrm{S}$ & $47^{\circ} 34.811^{\prime} \mathrm{W}$ & 0,03 & 6,776 & 44,4 & 7,6 & 17,1 \\
\hline Estação IG 9A & 0 & $12 / 02 / 2009$ & 10 & 27,0 & $24^{\circ} 42.187^{\prime} \mathrm{S}$ & $47^{\circ} 33.765^{\prime} \mathrm{W}$ & 0,17 & 6,953 & 42,1 & 8,2 & 19,5 \\
\hline Estação IG 9B & 3 & $12 / 02 / 2009$ & 10 & 27,0 & $24^{\circ} 42.187^{\prime} \mathrm{S}$ & $47^{\circ} 32.196^{\prime} \mathrm{W}$ & 0,26 & 6,973 & 495,7 & 448,6 & 90,5 \\
\hline Estação IG 10A & 0 & $12 / 02 / 2009$ & 10 & 27,0 & $24^{\circ} 42.823^{\prime} \mathrm{S}$ & $47^{\circ} 33.765^{\prime} \mathrm{W}$ & 0,05 & 6,918 & 208,5 & 179,6 & 86,1 \\
\hline Estação IG 10B & 5 & $12 / 02 / 2009$ & 10 & 27,0 & $24^{\circ} 42.823^{\prime} \mathrm{S}$ & $47^{\circ} 33.765^{\prime} \mathrm{W}$ & 0,05 & 6,865 & 28,9 & 4,6 & 16,0 \\
\hline Estação IG 11A & 0 & $12 / 02 / 2009$ & 10 & 27,0 & $24^{\circ} 42.026^{\prime} \mathrm{S}$ & $47^{\circ} 34.045^{\prime} \mathrm{W}$ & 0,04 & 6,727 & 417,4 & 397,0 & 95,1 \\
\hline Estação IG 11B & 5 & $12 / 02 / 2009$ & 10 & 27,0 & $24^{\circ} 42.026^{\prime} \mathrm{S}$ & $47^{\circ} 34.045^{\prime} \mathrm{W}$ & 0,76 & 6,758 & 308,1 & 285,9 & 92,8 \\
\hline
\end{tabular}


TABELA 5 - Concentrações de atividade dos isótopos naturais de Ra e nutrientes no sistema estuarino Cananéia-Iguape (Fevereiro/ 09).

\begin{tabular}{|c|c|c|c|c|c|c|c|c|}
\hline Amostras & $\begin{array}{c}{ }^{226} \mathrm{Ra} \\
\left(\mathrm{mBq} \mathrm{L}^{-1}\right)\end{array}$ & $\begin{array}{c}{ }^{228} \mathrm{Ra} \\
\left(\mathrm{mBq} \mathrm{L}^{-1}\right)\end{array}$ & ${ }^{228} \mathrm{Ra} /{ }^{226} \mathrm{Ra}$ & $\begin{array}{l}\text { Amônio } \\
\left.(\mu \mathrm{mol} \mathrm{L})^{-1}\right)\end{array}$ & $\begin{array}{l}\text { Nitrato } \\
\left.(\mu \mathrm{mol} \mathrm{L})^{-1}\right)\end{array}$ & $\begin{array}{c}\text { Nitrito } \\
\left.(\mu \mathrm{mol} \mathrm{L})^{-1}\right)\end{array}$ & $\begin{array}{c}\text { Silicato } \\
\left.(\mu \mathrm{mol} \mathrm{L})^{-1}\right)\end{array}$ & $\begin{array}{c}\text { Fosfato } \\
\left(\mu \mathrm{mol} \mathrm{L}^{-1}\right)\end{array}$ \\
\hline Estação CAN 1A & $3,8 \pm 0,2$ & $45 \pm 5$ & 11,8 & 1,48 & 0,59 & 0,20 & 11,71 & 0,23 \\
\hline Estação CAN 2A & $2,9 \pm 0,3$ & $22 \pm 1$ & 7,6 & 4,70 & 2,20 & 0,32 & 42,07 & 0,89 \\
\hline Estação CAN 3A & $5,0 \pm 1,0$ & $24 \pm 4$ & 5,1 & 5,42 & 1,33 & 0,19 & 35,80 & 0,80 \\
\hline Estação CAN 4A & $2,9 \pm 0,2$ & $22 \pm 1$ & 7,5 & 3,53 & 0,98 & 0,18 & 46,78 & 0,86 \\
\hline Estação IG 6A & $1,8 \pm 0,8$ & $18 \pm 1$ & 10,0 & 4,81 & 6,35 & 0,46 & 121,55 & 1,69 \\
\hline Estação IG 6B & $2,8 \pm 0,6$ & $19 \pm 4$ & 6,8 & 5,31 & 7,57 & 0,41 & 130,91 & 2,03 \\
\hline Estação IG 7A & $2,3 \pm 0,3$ & $13 \pm 1$ & 5,7 & 4,09 & 15,25 & 0,30 & 179,19 & 1,49 \\
\hline Estação IG 7B & $6,6 \pm 0,2$ & $20 \pm 2$ & 3,0 & 4,35 & 15,50 & 0,25 & 193,42 & 1,38 \\
\hline Estação IG 8A & $2,9 \pm 0,2$ & $13 \pm 1$ & 4,5 & 2,51 & 15,69 & 0,25 & 185,05 & 1,26 \\
\hline Estação IG 8B & $4,4 \pm 0,6$ & $14 \pm 1$ & 3,2 & 1,77 & 15,55 & 0,20 & 177,22 & 1,38 \\
\hline Estação IG 9A & $2,4 \pm 1,3$ & $19 \pm 2$ & 7,9 & 1,96 & 16,47 & 0,25 & 113,67 & 1,52 \\
\hline Estação IG 9B & $1,7 \pm 0,1$ & $17 \pm 1$ & 10,0 & 2,02 & 16,66 & 0,25 & 153,08 & 1,55 \\
\hline Estação IG 10A & $2,0 \pm 0,2$ & $15 \pm 1$ & 7,5 & 2,28 & 16,52 & 0,20 & 134,31 & 1,56 \\
\hline Estação IG 10B & $2,4 \pm 0,2$ & $14 \pm 2$ & 5,8 & 1,94 & 16,08 & 0,25 & 150,12 & 1,52 \\
\hline Estação IG 11A & $1,6 \pm 0,4$ & $16 \pm 1$ & 10,0 & 1,66 & 16,08 & 0,25 & 161,45 & 1,33 \\
\hline Estação IG 11B & $2,9 \pm 0,9$ & $19 \pm 2$ & 6,6 & 0,93 & 15,89 & 0,25 & 156,53 & 1,44 \\
\hline
\end{tabular}


TABELA 6 - Coordenadas geográficas das amostras das estações hidroquímicas do sistema estuarino Cananéia-Iguape (Agosto/ 2009).

\begin{tabular}{|c|c|c|c|c|c|c|c|c|c|c|c|}
\hline Amostras & $\begin{array}{c}\text { Profundidade } \\
(\mathbf{m})\end{array}$ & $\begin{array}{c}\text { Data da } \\
\text { coleta }\end{array}$ & $\begin{array}{c}\text { Volume } \\
\text { (L) }\end{array}$ & $\begin{array}{c}\mathrm{T} \\
\left({ }^{\circ} \mathrm{C}\right) \\
\end{array}$ & Latitude & Longitude & Salinidade & pH & $\begin{array}{c}\text { MES } \\
(\mathrm{mg} / \mathrm{L}) \\
\end{array}$ & $\begin{array}{c}\text { MO } \\
(\mathrm{mg} / \mathrm{L}) \\
\end{array}$ & $\begin{array}{c}\text { MO } \\
\%\end{array}$ \\
\hline Estação CAN 1A & 0 & $20 / 08 / 2009$ & 20 & 20,80 & $25^{\circ} 03.405^{\prime} \mathrm{S}$ & $47^{\circ} 54.944^{\prime} \mathrm{W}$ & 24,44 & 8,199 & 62,7 & 4,2 & 6,7 \\
\hline Estação CAN 1B & 3 & $20 / 08 / 2009$ & 20 & 22,10 & $25^{\circ} 03.405^{\prime} \mathrm{S}$ & $47^{\circ} 54.944^{\prime} \mathrm{W}$ & 27,96 & 8,259 & 81,8 & 38,9 & 47,6 \\
\hline Estação CAN 2A & 0 & 20/08/2009 & 20 & 21,20 & $25^{\circ} 02.762^{\prime} \mathrm{S}$ & $47^{\circ} 54.992^{\prime} \mathrm{W}$ & 22,90 & 8,204 & 56,7 & 19,3 & 34,1 \\
\hline Estação CAN 2B & 3 & 20/08/2009 & 20 & 20,80 & $25^{\circ} 02.762^{\prime} \mathrm{S}$ & $47^{\circ} 54.992^{\prime} \mathrm{W}$ & 22,25 & 8,229 & 60,7 & 20,0 & 33,0 \\
\hline Estação CAN 3A & 0 & 20/08/2009 & 20 & 20,75 & $25^{\circ} 01.893^{\prime} \mathrm{S}$ & $47^{\circ} 54.900^{\prime} \mathrm{W}$ & 29,88 & 8,417 & 84,7 & 29,6 & 34,9 \\
\hline Estação CAN 3B & 5 & 20/08/2009 & 20 & 20,70 & $25^{\circ} 01.893^{\prime} \mathrm{S}$ & $47^{\circ} 54.900^{\prime} \mathrm{W}$ & 28,98 & 8,426 & 85,3 & 18,0 & 21,1 \\
\hline Estação CAN 4A & 0 & 20/08/2009 & 20 & 20,35 & $25^{\circ} 01.104^{\prime} \mathrm{S}$ & $47^{\circ} 55.540^{\prime} \mathrm{W}$ & 31,58 & 8,521 & 25,1 & 10,2 & 40,7 \\
\hline Estação CAN 4B & 5 & 20/08/2009 & 20 & 20,25 & $25^{\circ} 01.104^{\prime} \mathrm{S}$ & $47^{\circ} 55.540^{\prime} \mathrm{W}$ & 32,33 & 8,544 & 43,8 & 13,8 & 31,5 \\
\hline Estação CAN 5A & 0 & $20 / 08 / 2009$ & 20 & 20,60 & $25^{\circ} 00.501^{\prime} \mathrm{S}$ & $47^{\circ} 55.326^{\prime} \mathrm{W}$ & 27,59 & 8,512 & 64,4 & 25,6 & 39,7 \\
\hline Estação CAN 5B & 5 & 20/08/2009 & 20 & 20,40 & $25^{\circ} 00.501^{\prime} \mathrm{S}$ & $47^{\circ} 55.326^{\prime} \mathrm{W}$ & 31,64 & 8,508 & 22,4 & 9,6 & 42,6 \\
\hline Estação IG 6A & 0 & $21 / 08 / 2009$ & 20 & 20,90 & $24^{\circ} 54.179^{\prime} \mathrm{S}$ & $47^{\circ} 48.512^{\prime} \mathrm{W}$ & 7,67 & 7,358 & 37,3 & 10,4 & 28,0 \\
\hline Estação IG 6B & 5 & $21 / 08 / 2009$ & 20 & 17,50 & $24^{\circ} 54.179^{\prime} \mathrm{S}$ & $47^{\circ} 48,512^{\prime} \mathrm{W}$ & 7,77 & 7,394 & 36,0 & 12,0 & 33,3 \\
\hline Estação IG 7A & 0 & $21 / 08 / 2009$ & 20 & 20,65 & $24^{\circ} 44.456^{\prime} \mathrm{S}$ & $47^{\circ} 35.881^{\prime} \mathrm{W}$ & 0,67 & 7,346 & 31,1 & 7,6 & 24,3 \\
\hline Estação IG 7B & 5 & $21 / 08 / 2009$ & 20 & 20,75 & $24^{\circ} 44.456^{\prime} \mathrm{S}$ & $47^{\circ} 35.881^{\prime} \mathrm{W}$ & 0,65 & 7,275 & 49,3 & 9,6 & 19,4 \\
\hline Estação IG 8A & 0 & $21 / 08 / 2009$ & 20 & 20,70 & $24^{\circ} 43.956^{\prime} \mathrm{S}$ & $47^{\circ} 34.809^{\prime} \mathrm{W}$ & 0,78 & 7,498 & 33,5 & 6,5 & 19,4 \\
\hline Estação IG 8B & 3 & $21 / 08 / 2009$ & 20 & 20,70 & $24^{\circ} 43.956^{\prime} \mathrm{S}$ & $47^{\circ} 34.809^{\prime} \mathrm{W}$ & 0,91 & 7,183 & 87,5 & 14,8 & 16,9 \\
\hline Estação IG 9A & 0 & $21 / 08 / 2009$ & 20 & 20,70 & $24^{\circ} 42.159^{\prime} \mathrm{S}$ & $47^{\circ} 32.202^{\prime} \mathrm{W}$ & 11,62 & 7,887 & 48,3 & 15,3 & 31,6 \\
\hline Estação IG 9B & 3 & $21 / 08 / 2009$ & 20 & 20,65 & $24^{\circ} 42.159^{\prime} \mathrm{S}$ & $47^{\circ} 32.202^{\prime} \mathrm{W}$ & 13,59 & 7,951 & 48,8 & 17,5 & 35,9 \\
\hline Estação IG 11A & 0 & $21 / 08 / 2009$ & 20 & 20,45 & $24^{\circ} 41.993^{\prime} \mathrm{S}$ & $47^{\circ} 34.073^{\prime} \mathrm{W}$ & 1,07 & 7,313 & 18,9 & 7,4 & 39,2 \\
\hline Estação IG 11B & 5 & $21 / 08 / 2009$ & 20 & 20,75 & $24^{\circ} 41.993^{\prime} \mathrm{S}$ & $47^{\circ} 34.073^{\prime} \mathrm{W}$ & 1,18 & 7,372 & 19,3 & 5,7 & 29,9 \\
\hline
\end{tabular}


TABELA 7 - Concentrações de atividade dos isótopos naturais de Ra e nutrientes no sistema estuarino Cananéia-Iguape (Agosto/ 2009).

\begin{tabular}{|c|c|c|c|c|c|c|c|c|}
\hline Amostras & $\begin{array}{c}{ }^{226} \mathrm{Ra} \\
\left(\mathrm{mBq} \mathrm{L}^{-1}\right)\end{array}$ & $\begin{array}{c}{ }^{228} \mathrm{Ra} \\
\left(\mathrm{mBq} \mathrm{L}^{-1}\right)\end{array}$ & ${ }^{228} \mathrm{Ra} /{ }^{226} \mathrm{Ra}$ & $\begin{array}{c}\text { Amônio } \\
\left(\mu \mathrm{mol} \mathrm{L}^{-1}\right)\end{array}$ & $\begin{array}{c}\text { Nitrato } \\
\left.(\mu \mathrm{mol} \mathrm{L})^{-1}\right)\end{array}$ & $\begin{array}{c}\text { Nitrito } \\
\left(\mu \mathrm{mol} \mathrm{L}^{-1}\right)\end{array}$ & $\begin{array}{c}\text { Silicato } \\
\left.(\mu \mathrm{mol} \mathrm{L})^{-1}\right)\end{array}$ & $\begin{array}{c}\text { Fosfato } \\
\left.(\mu \mathrm{mol} \mathrm{L})^{-1}\right)\end{array}$ \\
\hline Estação CAN 1B & $4,7 \pm 0,5$ & $23 \pm 5$ & 4,8 & 2,58 & 3,02 & 0,43 & 32,83 & 0,63 \\
\hline Estação CAN 2B & $3,5 \pm 0,1$ & $20 \pm 1$ & 5,8 & 4,50 & 6,00 & 0,37 & 59,32 & 0,98 \\
\hline Estação CAN 3A & $4,0 \pm 0,6$ & $23 \pm 2$ & 5,7 & 1,94 & 2,15 & 0,33 & 25,20 & 0,61 \\
\hline Estação CAN 3B & $3,2 \pm 0,5$ & $21 \pm 2$ & 6,6 & 0,99 & 2,51 & 0,37 & 29,12 & 0,55 \\
\hline Estação CAN 4B & $3,3 \pm 0,1$ & $17 \pm 1$ & 5,0 & 2,36 & 0,82 & 0,19 & 18,59 & 0,47 \\
\hline Estação CAN 5A & $5,3 \pm 2,0$ & $22 \pm 4$ & 4,1 & 1,84 & 3,22 & 0,37 & 32,83 & 0,69 \\
\hline Estação CAN 5B & $5,3 \pm 3,0$ & $20 \pm 1$ & 3,7 & 1,94 & 1,11 & 0,23 & 15,26 & 0,48 \\
\hline Estação IG 6A & $3,7 \pm 0,4$ & $20 \pm 1$ & 5,5 & 0,65 & 0,91 & 0,35 & 13,07 & 0,51 \\
\hline Estação IG 6B & $3,4 \pm 0,1$ & $20 \pm 1$ & 5,8 & 3,30 & 14,41 & 0,40 & 126,96 & 1,43 \\
\hline Estação IG 9A & $4,1 \pm 1,0$ & $19 \pm 1$ & 4,8 & 3,13 & 18,27 & 0,24 & 142,02 & 1,70 \\
\hline Estação IG 9B & $5,2 \pm 1,7$ & $20 \pm 1$ & 3,8 & 2,91 & 13,61 & 0,28 & 132,88 & 1,63 \\
\hline Estação IG 11A & $3,2 \pm 0,6$ & $18 \pm 1$ & 5,7 & 1,86 & 15,53 & 0,21 & 168,38 & 3,47 \\
\hline Estação IG 11B & $3,7 \pm 0,4$ & $18 \pm 1$ & 4,9 & 2,74 & 18,31 & 0,21 & 167,31 & 2,77 \\
\hline
\end{tabular}


TABELA 8 - Coordenadas geográficas dos poços de águas subterrâneas coletados em Cananéia e Ilha Comprida coletadas (Abril/ 2009).

\begin{tabular}{|c|c|c|c|c|c|c|c|}
\hline Amostras & Data da coleta & Volume (L) & $\begin{array}{c}\mathrm{T} \\
\left({ }^{\circ} \mathrm{C}\right)\end{array}$ & Latitude & Longitude & Salinidade & $\mathbf{p H}$ \\
\hline Cananéia/Poço 1 & $13 / 04 / 2009$ & 10 & 25 & $25^{\circ} 01.231^{\prime} \mathrm{S}$ & $47^{\circ} 56.028^{\prime} \mathrm{W}$ & 0,05 & - \\
\hline Cananéia/Poço 2 & $13 / 04 / 2009$ & 10 & 26 & $25^{\circ} 01.204^{\prime} \mathrm{S}$ & $47^{\circ} 55.965^{\prime} \mathrm{W}$ & 0,05 & - \\
\hline Cananéia/Poço 3 & $13 / 04 / 2009$ & 10 & 24 & $24^{\circ} 57.953^{\prime} \mathrm{S}$ & $47^{\circ} 54.288^{\prime} \mathrm{W}$ & 0,02 & 4,465 \\
\hline Cananéia/Poço 4 & $13 / 04 / 2009$ & 10 & 24 & $24^{\circ} 58.135^{\prime} \mathrm{S}$ & $47^{\circ} 54.246^{\prime} \mathrm{W}$ & 0,09 & 4,384 \\
\hline Cananéia/Poço 5 & $13 / 04 / 2009$ & 10 & 24 & $24^{\circ} 58.070^{\prime} \mathrm{S}$ & $47^{\circ} 54.327^{\prime} \mathrm{W}$ & 0,03 & 5,122 \\
\hline Cananéia/Poço 6 & $13 / 04 / 2009$ & 10 & 26 & $24^{\circ} 57.879^{\prime} \mathrm{S}$ & $47^{\circ} 54.220^{\prime} \mathrm{W}$ & 0,10 & 5,360 \\
\hline Cananéia/Poço 7 & $13 / 04 / 2009$ & 10 & 24 & - & - & 0,08 & 5,562 \\
\hline Ilha Comprida/Poço 8 & $14 / 04 / 2009$ & 10 & 26 & $25^{\circ} 01.671^{\prime} \mathrm{S}$ & $4753.177^{\prime} \mathrm{W}$ & 0,23 & 5,260 \\
\hline Ilha Comprida/Poço 9 & $14 / 04 / 2009$ & 10 & 27 & $25^{\circ} 01.624^{\prime} \mathrm{S}$ & $47^{\circ} 53.115^{\prime} \mathrm{W}$ & 0,05 & 6,489 \\
\hline Ilha Comprida/Poço10 & $14 / 04 / 2009$ & 10 & 27 & $25^{\circ} 01.664^{\prime} \mathrm{S}$ & $4^{\circ} 52.975^{\prime} \mathrm{W}$ & 0,11 & 7,415 \\
\hline Ilha Comprida/Poço11 & $14 / 04 / 2009$ & 10 & 25 & $25^{\circ} 01.802^{\prime} \mathrm{S}$ & $47^{\circ} 53.149^{\prime} \mathrm{W}$ & 0,02 & 5,515 \\
\hline Ilha Comprida/Poço12 & $14 / 04 / 2009$ & 10 & 29 & $25^{\circ} 01.033^{\prime} \mathrm{S}$ & $47^{\circ} 52.700^{\prime} \mathrm{W}$ & 0,10 & 6,639 \\
\hline Ilha Comprida/Poço13 & $14 / 04 / 2009$ & 10 & 28 & $25^{\circ} 02.295^{\prime} \mathrm{S}$ & $47^{\circ} 54.755^{\prime} \mathrm{W}$ & 0,02 & 5,748 \\
\hline
\end{tabular}


TABELA 9 - Concentração de isótopos naturais de Ra e nutrientes nas águas subterrâneas coletadas em Cananéia e Ilha Comprida (Abril/ 2009).

\begin{tabular}{|c|c|c|c|c|c|c|c|}
\hline Amostras & $\begin{array}{c}{ }^{226} \mathrm{Ra} \\
\left(\mathrm{mBq} \mathrm{L}^{-1}\right)\end{array}$ & $\begin{array}{c}{ }^{228} \mathrm{Ra} \\
\left(\mathrm{mBq} \mathrm{L}^{-1}\right)\end{array}$ & ${ }^{228} \mathrm{Ra} /{ }^{226} \mathrm{Ra}$ & $\begin{array}{c}\text { Nitrato } \\
\left.(\mu \mathrm{mol} \mathrm{L})^{-1}\right)\end{array}$ & $\begin{array}{c}\text { Nitrito } \\
\left.(\mu \mathrm{mol} \mathrm{L})^{-1}\right)\end{array}$ & $\begin{array}{c}\text { Silicato } \\
\left(\mu \mathrm{mol} \mathrm{L} \mathbf{L}^{-1}\right)\end{array}$ & $\begin{array}{c}\text { Fosfato } \\
\left(\mu \mathrm{mol} \mathrm{L} \mathrm{L}^{-1}\right)\end{array}$ \\
\hline Cananéia/Poço 1 & $3,6 \pm 0,2$ & $20 \pm 2$ & 5,6 & 42,48 & 0,04 & 2,14 & 0,72 \\
\hline Cananéia/Poço 2 & $3,8 \pm 1,3$ & $24 \pm 2$ & 6,3 & 41,46 & 0,03 & 16,98 & 0,18 \\
\hline Cananéia/Poço 3 & $3,9 \pm 0,8$ & $21 \pm 2$ & 5,4 & 0,13 & 0,03 & 12,10 & 0,17 \\
\hline Cananéia/Poço 4 & $12 \pm 1$ & $39 \pm 3$ & 3,3 & 165,4 & 0,01 & 5,41 & 0,14 \\
\hline Cananéia/Poço 5 & $5,6 \pm 0,8$ & $27 \pm 2$ & 4,8 & 130,0 & 0,13 & 2,74 & 0,15 \\
\hline Cananéia/Poço 6 & $2,9 \pm 0,5$ & $26 \pm 2$ & 8,9 & 25,39 & 0,01 & 3,86 & 0,15 \\
\hline Cananéia/Poço 7 & $2,5 \pm 0,6$ & $18 \pm 1$ & 7,2 & 5,42 & 0,03 & 1,65 & 0,13 \\
\hline Ilha Comprida/Poço 8 & $1,8 \pm 0,3$ & $25 \pm 6$ & 13,9 & 0,03 & 0,18 & 255,5 & 5,02 \\
\hline Ilha Comprida/Poço 9 & $3,9 \pm 3,6$ & $25 \pm 6$ & 6,4 & 77,30 & 0,48 & 98,41 & 0,55 \\
\hline Ilha Comprida/Poço10 & $0,6 \pm 0,1$ & $20 \pm 1$ & 31,7 & 136,1 & 3,38 & 73,3 & 0,74 \\
\hline Ilha Comprida/Poço11 & $2,0 \pm 0,3$ & $23 \pm 2$ & 11,5 & 5,95 & 0,01 & 2,13 & 0,16 \\
\hline Ilha Comprida/Poço12 & $1,4 \pm 0,5$ & $24 \pm 2$ & 17,1 & 9,62 & 0,03 & 4,13 & 0,18 \\
\hline Ilha Comprida/Poço13 & $2,3 \pm 0,1$ & $24 \pm 1$ & 10,4 & 16,06 & 0,01 & 3,37 & 0,21 \\
\hline
\end{tabular}


TABELA10 - Coordenadas geográficas dos poços de águas subterrâneas coletados em Cananéia, Iguape e Ilha Comprida (Agosto/ 2009).

\begin{tabular}{|c|c|c|c|c|c|c|c|}
\hline Amostras & Data da coleta & $\begin{array}{c}\text { Volume } \\
(\mathrm{L})\end{array}$ & $\begin{array}{c}\mathrm{T} \\
\left({ }^{\circ} \mathrm{C}\right)\end{array}$ & Latitude & Longitude & Salinidade & pH \\
\hline Cananéia/Poço 1 & $19 / 08 / 2009$ & 20 & 21,2 & $25^{\circ} 01.231^{\prime} \mathrm{S}$ & $047^{\circ} 56.028^{\prime} \mathrm{W}$ & 0,02 & 5,560 \\
\hline Cananéia/Poço 2 & $18 / 08 / 2009$ & 20 & 21,5 & $25^{\circ} 01.204^{\prime} \mathrm{S}$ & $047^{\circ} 55.965^{\prime} \mathrm{W}$ & 0,04 & 5,974 \\
\hline Cananéia/Poço 3 & $18 / 08 / 2009$ & 20 & 21,8 & $24^{\circ} 57.953^{\prime} \mathrm{S}$ & $047^{\circ} 54.288^{\prime} \mathrm{W}$ & 0,02 & 5,656 \\
\hline Cananéia/Poço 4 & $18 / 08 / 2009$ & 20 & 22,5 & $24^{\circ} 58.135^{\prime} \mathrm{S}$ & $047^{\circ} 54.246^{\prime} \mathrm{W}$ & 0,09 & 5,274 \\
\hline Cananéia/Poço 5 & $18 / 08 / 2009$ & 20 & 21,2 & $24^{\circ} 58.070^{\prime} \mathrm{S}$ & $047^{\circ} 54.327^{\prime} \mathrm{W}$ & 0,03 & 5,150 \\
\hline Cananéia/Poço 6 & $18 / 08 / 2009$ & 20 & 22,9 & $24^{\circ} 57.879^{\prime} \mathrm{S}$ & $047^{\circ} 54.220^{\prime} \mathrm{W}$ & 0,02 & 5,292 \\
\hline Ilha Comprida/Poço 8 & $19 / 08 / 2009$ & 20 & 22,8 & $25^{\circ} 01.671^{\prime} \mathrm{S}$ & $047^{\circ} 53.177^{\prime} \mathrm{W}$ & 0,23 & 8,232 \\
\hline Ilha Comprida/Poço 9 & $19 / 08 / 2009$ & 20 & 21,1 & $25^{\circ} 01.624^{\prime} \mathrm{S}$ & $047^{\circ} 53.115^{\prime} \mathrm{W}$ & 0,04 & 6,359 \\
\hline Ilha Comprida/Poço10 & $19 / 08 / 2009$ & 20 & 22,3 & $25^{\circ} 01.664^{\prime} \mathrm{S}$ & $04^{\circ} 52.975^{\prime} \mathrm{W}$ & 0,06 & 7,604 \\
\hline Ilha Comprida/Poço11 & $19 / 08 / 2009$ & 20 & 23,6 & $25^{\circ} 01.802^{\prime} \mathrm{S}$ & $047^{\circ} 53.149^{\prime} \mathrm{W}$ & 0 & 5,951 \\
\hline Ilha Comprida/Poço12 & $19 / 08 / 2009$ & 20 & 24,6 & $25^{\circ} 01.033^{\prime} \mathrm{S}$ & $047^{\circ} 52.700^{\prime} \mathrm{W}$ & 0,06 & 5,558 \\
\hline Ilha Comprida/Poço13 & $19 / 08 / 2009$ & 20 & 22,1 & $25^{\circ} 02.295^{\prime} \mathrm{S}$ & $047^{\circ} 54.755^{\prime} \mathrm{W}$ & 0,01 & 5,380 \\
\hline Iguape/Poço 14 & $22 / 08 / 2009$ & 20 & 20,5 & $24^{\circ} 42.700^{\prime} \mathrm{S}$ & $047^{\circ} 33.113^{\prime} \mathrm{W}$ & 0,16 & 6,759 \\
\hline Iguape/Poço 15 & $22 / 08 / 2009$ & 20 & 21,0 & $24^{\circ} 42.516^{\prime} \mathrm{S}$ & $047^{\circ} 33.286^{\prime} \mathrm{W}$ & 0,15 & 7,025 \\
\hline Iguape/Poço 16 & $22 / 08 / 2009$ & 20 & 18,8 & $24^{\circ} 41.046^{\prime} \mathrm{S}$ & $047^{\circ} 28.230^{\prime} \mathrm{W}$ & 0,31 & 7,522 \\
\hline Iguape/Poço 17 & $22 / 08 / 2009$ & 20 & 21,8 & $24^{\circ} 41.500^{\prime} \mathrm{S}$ & $047^{\circ} 35.300^{\prime} \mathrm{W}$ & 0,02 & 6,091 \\
\hline Iguape/Poço 18 & $22 / 08 / 2009$ & 20 & 20,1 & $24^{\circ} 41.198^{\prime} \mathrm{S}$ & $047^{\circ} 35.609^{\prime} \mathrm{W}$ & 0,06 & 5,119 \\
\hline
\end{tabular}


TABELA 11 - Concentração de isótopos naturais de Ra e nutrientes nas águas subterrâneas coletadas em Cananéia, Iguape e Ilha Comprida (Agosto/ 2009).

\begin{tabular}{|c|c|c|c|c|c|c|c|c|}
\hline Amostras & $\begin{array}{c}{ }^{226} \mathrm{Ra} \\
\left(\mathrm{mBq} \mathrm{L}^{-1}\right)\end{array}$ & $\begin{array}{c}{ }^{228} \mathrm{Ra} \\
\left(\mathrm{mBq} \mathrm{L}^{-1}\right)\end{array}$ & ${ }^{228} \mathrm{Ra} /{ }^{226} \mathrm{Ra}$ & $\begin{array}{c}\text { Amônio } \\
\left.(\mu \mathrm{mol} \mathrm{L})^{-1}\right)\end{array}$ & $\begin{array}{c}\text { Nitrato } \\
\left.(\mu \mathrm{mol} \mathrm{L})^{-1}\right)\end{array}$ & $\left.\begin{array}{c}\text { Nitrito } \\
(\mu \mathrm{mol} \mathrm{L}\end{array}\right)$ & $\begin{array}{c}\text { Silicato } \\
\left.(\mu \mathrm{mol} \mathrm{L})^{-1}\right)\end{array}$ & $\begin{array}{c}\text { Fosfato } \\
\left.(\mu \mathrm{mol} \mathrm{L})^{-1}\right)\end{array}$ \\
\hline Cananéia/Poço 1 & $6,0 \pm 2,0$ & $32 \pm 2$ & 5,3 & 1,23 & 10,45 & 0,09 & 6,77 & 0,08 \\
\hline Cananéia/Poço 2 & $3,4 \pm 1,0$ & $20 \pm 2$ & 5,8 & 0,26 & 630,0 & 0,01 & 24,85 & 0,05 \\
\hline Cananéia/Poço 3 & $3,0 \pm 1,0$ & $19 \pm 4$ & 5,7 & 5,310 & 0,08 & 0,01 & 7,89 & 0,03 \\
\hline Cananéia/Poço 4 & $23 \pm 3$ & $27 \pm 2$ & 1,1 & 2,60 & 495,7 & 0,17 & 5,55 & 0,03 \\
\hline Cananéia/Poço 5 & $9,0 \pm 1,0$ & $27 \pm 2$ & 3,0 & 0,24 & 280,0 & 0,01 & 9,54 & 0,01 \\
\hline Cananéia/Poço 6 & $6,0 \pm 0,2$ & $15 \pm 1$ & 2,5 & 19,07 & 0,12 & 0,02 & 24,85 & 0,01 \\
\hline Ilha Comprida/Poço 8 & $1,2 \pm 0,2$ & $17 \pm 1$ & 14,5 & 38,42 & 0,26 & 0,06 & 149,30 & 3,41 \\
\hline Ilha Comprida/Poço 9 & $0,8 \pm 0,3$ & $21 \pm 4$ & 25,9 & 0,30 & 130,5 & 0,11 & 61,32 & 0,11 \\
\hline Ilha Comprida/Poço10 & $2,3 \pm 0,1$ & $17 \pm 1$ & 7,5 & 0,45 & 26,86 & 2,30 & 102,90 & 0,42 \\
\hline Ilha Comprida/Poço11 & $3,0 \pm 1,0$ & $23 \pm 4$ & 7,1 & 0,34 & 0 & 0 & 3,84 & 0,02 \\
\hline Ilha Comprida/Poço12 & $0,8 \pm 0,1$ & $21 \pm 1$ & 26,7 & 0,56 & 373,1 & 0,27 & 13,44 & 0,06 \\
\hline Ilha Comprida/Poço13 & $3,6 \pm 0,6$ & $25 \pm 1$ & 7,0 & 0,99 & 5,65 & 0,00 & 6,29 & 0,04 \\
\hline Iguape/Poço 14 & $8,0 \pm 1,0$ & $29 \pm 2$ & 3,6 & 15,18 & 36,91 & 0,42 & 53,00 & 0,15 \\
\hline Iguape/Poço 15 & $0,8 \pm 0,2$ & $20 \pm 3$ & 24,9 & 1,05 & 782,4 & 1,57 & 113,60 & 31,0 \\
\hline Iguape/Poço 16 & 3,8 & 72 & 18,9 & 121,0 & 18,46 & 0,21 & 223,4 & 10,9 \\
\hline Iguape/Poço 17 & 6,9 & 54 & 7,8 & 1,23 & 16,02 & 0,31 & 122,1 & 1,97 \\
\hline Iguape/Poço 18 & $6,7 \pm 0,5$ & $20 \pm 2$ & 3,0 & 28,65 & 22,97 & 0,37 & 84,78 & 0,16 \\
\hline
\end{tabular}


TABELA 12 - Coordenadas geográficas dos poços de águas subterrâneas coletados em Cananéia, Iguape e Ilha Comprida (Abril/2010).

\begin{tabular}{|c|c|c|c|c|c|c|c|}
\hline Amostras & $\begin{array}{c}\text { Data da } \\
\text { coleta }\end{array}$ & $\begin{array}{c}\text { Volume } \\
\text { (L) }\end{array}$ & $\begin{array}{c}\mathrm{T} \\
\left({ }^{\circ} \mathrm{C}\right)\end{array}$ & Latitude & Longitude & Salinidade & pH \\
\hline Cananéia/Poço 1 & $28 / 04 / 2010$ & 10 & 24,0 & $25^{\circ} 01.231^{\prime} \mathrm{S}$ & $047^{\circ} 56.028^{\prime} \mathrm{W}$ & 0,33 & 5,669 \\
\hline Cananéia/Poço 2 & $28 / 04 / 2010$ & 10 & 25,0 & $25^{\circ} 01.204^{\prime} \mathrm{S}$ & $047^{\circ} 55.965^{\prime} \mathrm{W}$ & 0,08 & 6,315 \\
\hline Cananéia/Poço 3 & $27 / 04 / 2010$ & 10 & 22,0 & $24^{\circ} 57.953^{\prime} \mathrm{S}$ & $047^{\circ} 54.288^{\prime} \mathrm{W}$ & 0,01 & 5,027 \\
\hline Cananéia/Poço 4 & $27 / 04 / 2010$ & 10 & 23,0 & $24^{\circ} 58.135^{\prime} \mathrm{S}$ & $047^{\circ} 54.246^{\prime} \mathrm{W}$ & 0,03 & 5,306 \\
\hline Cananéia/Poço 5 & $27 / 04 / 2010$ & 10 & 24,0 & $24^{\circ} 58.070^{\prime} \mathrm{S}$ & $047^{\circ} 54.327^{\prime} \mathrm{W}$ & 0,03 & 5,421 \\
\hline Cananéia/Poço 6 & $27 / 04 / 2010$ & 10 & 24,0 & $24^{\circ} 57.879^{\prime} \mathrm{S}$ & $047^{\circ} 54.220^{\prime} \mathrm{W}$ & 0,06 & 5,929 \\
\hline Ilha Comprida/Poço 8 & $27 / 04 / 2010$ & 10 & 24,0 & $25^{\circ} 01.671^{\prime} \mathrm{S}$ & $047^{\circ} 53.177^{\prime} \mathrm{W}$ & 0,98 & 8,206 \\
\hline Ilha Comprida/Poço 9 & $27 / 04 / 2010$ & 10 & 24,0 & $25^{\circ} 01.624^{\prime} \mathrm{S}$ & $047^{\circ} 53.115^{\prime} \mathrm{W}$ & 0,16 & 6,514 \\
\hline Ilha Comprida/Poço10 & $27 / 04 / 2010$ & 10 & 24,0 & $25^{\circ} 01.664^{\prime} \mathrm{S}$ & $04^{\circ} 52.975^{\prime} \mathrm{W}$ & 0,02 & 7,502 \\
\hline Ilha Comprida/Poço11 & $27 / 04 / 2010$ & 10 & 24,0 & $25^{\circ} 01.802^{\prime} \mathrm{S}$ & $047^{\circ} 53.149^{\prime} \mathrm{W}$ & 0 & 5,180 \\
\hline Ilha Comprida/Poço12 & $27 / 04 / 2010$ & 10 & 24,0 & $25^{\circ} 01.033^{\prime} \mathrm{S}$ & $047^{\circ} 52.700^{\prime} \mathrm{W}$ & 0,03 & 5,895 \\
\hline Iguape/Poço 14 & $28 / 04 / 2010$ & 10 & 25,0 & $24^{\circ} 42.700^{\prime} \mathrm{S}$ & $047^{\circ} 33.113^{\prime} \mathrm{W}$ & 0,11 & 7,012 \\
\hline Iguape/Poço 16 & $28 / 04 / 2010$ & 10 & 25,0 & $24^{\circ} 41.046^{\prime} \mathrm{S}$ & $047^{\circ} 28.230^{\prime} \mathrm{W}$ & 1,50 & 7,656 \\
\hline Iguape/Poço 17 & $28 / 04 / 2010$ & 10 & 24,0 & $24^{\circ} 41.500^{\prime} \mathrm{S}$ & $047^{\circ} 35.300^{\prime} \mathrm{W}$ & 0,28 & 6,496 \\
\hline Iguape/Poço 18 & $28 / 04 / 2010$ & 10 & 25,0 & $24^{\circ} 41.198^{\prime} \mathrm{S}$ & $047^{\circ} 35.609^{\prime} \mathrm{W}$ & 0,33 & 5,198 \\
\hline
\end{tabular}


TABELA 13 - Concentração de isótopos naturais de Ra e nutrientes nas águas subterrâneas coletadas em Cananéia, Iguape e Ilha Comprida (Abril/2010).

\begin{tabular}{|c|c|c|c|c|c|c|c|c|}
\hline Amostras & $\begin{array}{c}{ }^{226} \mathrm{Ra} \\
\left(\mathrm{mBq} \mathrm{L}^{-1}\right)\end{array}$ & $\begin{array}{c}{ }^{228} \mathbf{R a} \\
\left(\mathrm{mBq} \mathrm{L}^{-1}\right)\end{array}$ & ${ }^{228} \mathrm{Ra} /{ }^{226} \mathrm{Ra}$ & 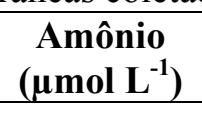 & $\begin{array}{c}\text { Nitrato } \\
\left.(\mu \mathrm{mol} \mathrm{L})^{-1}\right)\end{array}$ & $\left.\begin{array}{c}\text { Nitrito } \\
(\mu \mathrm{mol} \mathrm{L}\end{array}\right)$ & $\left.\begin{array}{c}\text { Silicato } \\
(\mu \mathrm{mol} \mathrm{L}\end{array}\right)$ & $\begin{array}{c}\text { Fosfato } \\
\left(\mu \mathrm{mol} \mathrm{L}^{-1}\right)\end{array}$ \\
\hline Cananéia/Poço 1 & $1,3 \pm 0,3$ & $22 \pm 1$ & 16,9 & 0,55 & 26,35 & 0,05 & 3,15 & 0,18 \\
\hline Cananéia/Poço 2 & $2,6 \pm 0,5$ & $20 \pm 1$ & 7,9 & 0,32 & 38,50 & 0,04 & 12,08 & 0,10 \\
\hline Cananéia/Poço 3 & $4,0 \pm 0,3$ & $17 \pm 1$ & 4,6 & 0,43 & 0,98 & 0,07 & 4,34 & 0,02 \\
\hline Cananéia/Poço 4 & $3,0 \pm 0,6$ & $21 \pm 2$ & 7,2 & 1,55 & 42,10 & 0,05 & 18,75 & 0,05 \\
\hline Cananéia/Poço 5 & $7,4 \pm 0,7$ & $22 \pm 2$ & 2,9 & 0,17 & 68,42 & 0,05 & 30,65 & 0,05 \\
\hline Cananéia/Poço 6 & $8,0 \pm 1,9$ & $20 \pm 5$ & 2,5 & 1,02 & 2,45 & 0,05 & 6,25 & 0,01 \\
\hline Cananéia/Poço 8 & $1,0 \pm 0,5$ & $14 \pm 2$ & 17,7 & 0,87 & 40,61 & 0,08 & 161,27 & 2,83 \\
\hline Ilha Comprida/Poço 9 & $1,2 \pm 0,6$ & $17 \pm 1$ & 14,1 & 0,36 & 55,40 & 0,07 & 25,83 & 0,07 \\
\hline Ilha Comprida/Poço10 & $0,8 \pm 0,1$ & $14 \pm 9$ & 16,8 & 1,79 & 29,65 & 0,10 & 100,23 & 0,19 \\
\hline Ilha Comprida/Poço11 & $1,9 \pm 0,5$ & $21 \pm 2$ & 11,5 & 0,23 & 0,98 & 0,09 & 3,45 & 0,07 \\
\hline Ilha Comprida/Poço12 & $4,0 \pm 2,0$ & $19 \pm 1$ & 5,5 & 2,15 & 10,78 & 0,06 & 8,27 & 0,07 \\
\hline Ilha Comprida/Poço14 & $5,0 \pm 0,4$ & $17 \pm 1$ & 3,5 & 13,08 & 98,43 & 6,55 & 22,02 & 0,29 \\
\hline Iguape/Poço 16 & $1,4 \pm 1,0$ & $15 \pm 1$ & 10,7 & 1,06 & 27,49 & 0,22 & 25,47 & 9,96 \\
\hline Iguape/Poço 17 & $4,5 \pm 0,4$ & $19 \pm 2$ & 4,3 & 7,16 & 4,29 & 0,31 & 3,69 & 1,02 \\
\hline Iguape/Poço 18 & $6,0 \pm 2,4$ & $16 \pm 1$ & 2,7 & 0,77 & 9,37 & 0,11 & 35,71 & 0,06 \\
\hline
\end{tabular}


TABELA 14 - Coordenadas geográficas dos poços de águas subterrâneas coletados em Cananéia, Iguape e Ilha Comprida (Maio/ 2010).

\begin{tabular}{|c|c|c|c|c|c|c|c|}
\hline Amostras & Data da coleta & $\begin{array}{c}\begin{array}{c}\text { Volume } \\
(\mathrm{L})\end{array} \\
\end{array}$ & $\begin{array}{c}\mathrm{T} \\
\left({ }^{\circ} \mathrm{C}\right)\end{array}$ & Latitude & Longitude & Salinidade & pH \\
\hline Cananéia/Poço 1 & $25 / 05 / 2010$ & 10 & 23,0 & $25^{\circ} 01.231^{\prime} \mathrm{S}$ & $047^{\circ} 56.028^{\prime} \mathrm{W}$ & 0,09 & 5,698 \\
\hline Cananéia/Poço 2 & $25 / 05 / 2010$ & 10 & 25,0 & $25^{\circ} 01.204^{\prime} \mathrm{S}$ & $047^{\circ} 55.965^{\prime} \mathrm{W}$ & 0,05 & 6,073 \\
\hline Cananéia/Poço 3 & $24 / 05 / 2010$ & 10 & 23,0 & $24^{\circ} 57.953^{\prime} \mathrm{S}$ & $047^{\circ} 54.288^{\prime} \mathrm{W}$ & 0,08 & 5,273 \\
\hline Cananéia/Poço 4 & $24 / 05 / 2010$ & 10 & 23,0 & $24^{\circ} 58.135^{\prime} \mathrm{S}$ & $047^{\circ} 54.246^{\prime} \mathrm{W}$ & 0,05 & 5,634 \\
\hline Cananéia/Poço 5 & $24 / 05 / 2010$ & 10 & 23,0 & $24^{\circ} 58.070^{\prime} \mathrm{S}$ & $047^{\circ} 54.327^{\prime} \mathrm{W}$ & 0,11 & 4,879 \\
\hline Cananéia/Poço 6 & $24 / 05 / 2010$ & 10 & 25,0 & $24^{\circ} 57.879^{\prime} \mathrm{S}$ & $047^{\circ} 54.220^{\prime} \mathrm{W}$ & 0,05 & 5,310 \\
\hline Ilha Comprida/Poço 8 & $24 / 05 / 2010$ & 10 & 23,0 & $25^{\circ} 01.671^{\prime} \mathrm{S}$ & $047^{\circ} 53.177^{\prime} \mathrm{W}$ & 0,07 & 8,301 \\
\hline Ilha Comprida/Poço 9 & $24 / 05 / 2010$ & 10 & 24,0 & $25^{\circ} 01.624^{\prime} \mathrm{S}$ & $047^{\circ} 53.115^{\prime} \mathrm{W}$ & 0,12 & 6,664 \\
\hline Ilha Comprida/Poço11 & $24 / 05 / 2010$ & 10 & 24,0 & $25^{\circ} 01.802^{\prime} \mathrm{S}$ & $047^{\circ} 53.149^{\prime} \mathrm{W}$ & 0,09 & 6,375 \\
\hline Ilha Comprida/Poço12 & $24 / 05 / 2010$ & 10 & 24,0 & $25^{\circ} 01.033^{\prime} \mathrm{S}$ & $047^{\circ} 52.700^{\prime} \mathrm{W}$ & 0,09 & 5,487 \\
\hline Iguape/Poço 13 & $24 / 05 / 2010$ & 10 & 24,0 & $24^{\circ} 02.295^{\prime} \mathrm{S}$ & $047^{\circ} 54.755^{\prime} \mathrm{W}$ & 0,05 & 5,079 \\
\hline Iguape/Poço 14 & $25 / 05 / 2010$ & 10 & 27,0 & $24^{\circ} 42.700^{\prime} \mathrm{S}$ & $047^{\circ} 33.113^{\prime} \mathrm{W}$ & 0,11 & 6,968 \\
\hline Iguape/Poço 17 & $25 / 05 / 2010$ & 10 & 27,0 & $24^{\circ} 41.500^{\prime} \mathrm{S}$ & $047^{\circ} 35.300^{\prime} \mathrm{W}$ & 0,11 & 6,680 \\
\hline Iguape/Poço 18 & $25 / 05 / 2010$ & 10 & 25,0 & $24^{\circ} 41.198^{\prime} \mathrm{S}$ & $047^{\circ} 35.609^{\prime} \mathrm{W}$ & 0,08 & 4,960 \\
\hline
\end{tabular}


TABELA 15 - Concentração de isótopos naturais de Ra e nutrientes nas águas subterrâneas coletadas em Cananéia, Iguape e Ilha Comprida (Maio/ 2010).

\begin{tabular}{|c|c|c|c|c|c|c|c|c|}
\hline Amostras & $\begin{array}{c}{ }^{226} \mathrm{Ra} \\
\left(\mathrm{mBq} \mathrm{L}^{-1}\right)\end{array}$ & $\begin{array}{c}{ }^{228} \mathrm{Ra} \\
\left(\mathrm{mBq} \mathbf{L}^{-1}\right)\end{array}$ & ${ }^{228} \mathbf{R a} /{ }^{226} \mathbf{R a}$ & $\begin{array}{c}\text { Amônio } \\
\left(\mu \mathrm{mol} \mathrm{L}{ }^{-1}\right)\end{array}$ & $\begin{array}{c}\text { Nitrato } \\
\left(\mu \mathrm{mol} \mathrm{L}{ }^{-1}\right)\end{array}$ & $\begin{array}{c}\text { Nitrito } \\
\left(\mu \mathrm{mol} \mathrm{L}{ }^{-1}\right)\end{array}$ & $\begin{array}{c}\text { Silicato } \\
\left(\mu \mathrm{mol} \mathrm{L}{ }^{-1}\right)\end{array}$ & $\begin{array}{c}\text { Fosfato } \\
\left.(\mu \mathrm{mol} \mathrm{L})^{-1}\right)\end{array}$ \\
\hline Cananéia/Poço 1 & $3,2 \pm 0,7$ & $25 \pm 6$ & 7,8 & 0,24 & 29,92 & 0,08 & 5,33 & 0,27 \\
\hline Cananéia/Poço 2 & $2,0 \pm 0,3$ & $20 \pm 1$ & 10,3 & 0,16 & 33,71 & 0,04 & 15,93 & 0,06 \\
\hline Cananéia/Poço 3 & $4,0 \pm 0,1$ & $18 \pm 3$ & 4,3 & 0,37 & 0,42 & 0,03 & 7,28 & 0,01 \\
\hline Cananéia/Poço 4 & $2,1 \pm 0,4$ & $25 \pm 1$ & 11,6 & 0,23 & 61,21 & 0,04 & 8,55 & 0,03 \\
\hline Cananéia/Poço 5 & $5,1 \pm 0,6$ & $27 \pm 2$ & 5,4 & 0,29 & 107,48 & 0,02 & 10,10 & 0,03 \\
\hline Cananéia/Poço 6 & $7,6 \pm 3,0$ & $19 \pm 4$ & 2,6 & 0,21 & 3,17 & 0,08 & 19,22 & 0,05 \\
\hline Ilha Comprida/Poço 8 & $2,7 \pm 0,4$ & $19 \pm 9$ & 6,8 & 0,18 & 0,33 & 0,07 & 341,57 & 2,44 \\
\hline Ilha Comprida/Poço 9 & $1,0 \pm 0,2$ & $23 \pm 2$ & 23,6 & 0,06 & 62,43 & 0,07 & 58,75 & 0,13 \\
\hline Ilha Comprida/Poço11 & $1,1 \pm 0,2$ & $19 \pm 2$ & 17,4 & 0,38 & 123,72 & 0,03 & 8,55 & 0,02 \\
\hline Ilha Comprida/Poço12 & $1,4 \pm 0,5$ & $23 \pm 2$ & 15,8 & 0,35 & 10,49 & 0,01 & 3,72 & 0,00 \\
\hline Iguape/Poço 13 & $7,0 \pm 1,8$ & $24 \pm 1$ & 3,4 & 0,62 & 5,28 & 0,02 & 4,26 & 0,03 \\
\hline Iguape/Poço 14 & $5,3 \pm 1,9$ & $25 \pm 6$ & 4,6 & 0,21 & 42,79 & 2,21 & 40,16 & 0,09 \\
\hline Iguape/Poço 17 & $4,1 \pm 0,2$ & $21 \pm 1$ & 5,3 & 0,35 & 2,36 & 0,24 & 5,53 & 1,23 \\
\hline Iguape/Poço 18 & $6,2 \pm 0,2$ & $16 \pm 2$ & 2,7 & 0,19 & 8,92 & 0,08 & 32,51 & 0,23 \\
\hline
\end{tabular}


TABELA 16 - Coordenadas geográficas das amostras de água de superfície do Rio Ribeira de Iguape (Fevereiro/ 2009).

\begin{tabular}{|c|c|c|c|c|c|c|c|c|c|c|}
\hline Amostras & Data da coleta & $\begin{array}{c}\text { Volume } \\
\text { (L) }\end{array}$ & $\begin{array}{c}\mathrm{T} \\
\left({ }^{\circ} \mathrm{C}\right)\end{array}$ & Latitude & Longitude & Salinidade & pH & $\begin{array}{c}\text { MES } \\
(\mathrm{mg} / \mathrm{L})\end{array}$ & $\begin{array}{c}\text { MO } \\
(\mathrm{mg} / \mathrm{L})\end{array}$ & $\begin{array}{c}\text { MO } \\
\%\end{array}$ \\
\hline RIB 01 & $13 / 02 / 2009$ & 5 & 27,5 & $24^{\circ} 41.470^{\prime} \mathrm{S}$ & $47^{\circ} 34.200^{\prime} \mathrm{W}$ & 0,02 & 6,752 & 53,3 & 20,3 & 38,1 \\
\hline RIB 02 & $13 / 02 / 2009$ & 5 & 27,5 & $24^{\circ} 41.700^{\prime} \mathrm{S}$ & $47^{\circ} 36.800^{\prime} \mathrm{W}$ & 0,04 & 6,787 & 1923,3 & 1878,7 & 97,7 \\
\hline RIB 03 & $13 / 02 / 2009$ & 5 & 26,5 & $24^{\circ} 40.250^{\prime} \mathrm{S}$ & $47^{\circ} 33.860^{\prime} \mathrm{W}$ & 0,03 & 6,712 & 1707,3 & 1686,7 & 98,8 \\
\hline RIB 04 & $13 / 02 / 2009$ & 5 & 27,0 & $24^{\circ} 40.510^{\prime} \mathrm{S}$ & $47^{\circ} 34.920^{\prime} \mathrm{W}$ & 0,03 & 6,823 & 1224,7 & 1212,0 & 99,0 \\
\hline RIB 05 & $13 / 02 / 2009$ & 5 & 28,5 & $24^{\circ} 40.750^{\prime} \mathrm{S}$ & $47^{\circ} 35.750^{\prime} \mathrm{W}$ & 0,02 & 6,842 & 34,0 & 14,0 & 41,2 \\
\hline RIB 06 & $13 / 02 / 2009$ & 5 & 27,0 & $24^{\circ} 40.190^{\prime} \mathrm{S}$ & $47^{\circ} 36.430^{\prime} \mathrm{W}$ & 0,04 & 6,855 & 2210,7 & 2190,0 & 99,1 \\
\hline
\end{tabular}

TABELA 17 - Concentração de isótopos naturais de Ra e nutrientes na água de superfície do Rio Ribeira de Iguape (Fevereiro/ 2009).

\begin{tabular}{|c|c|c|c|c|c|c|c|c|}
\hline Amostras & $\begin{array}{c}{ }^{226} \mathrm{Ra}^{-1} \\
\left(\mathrm{mBq} \mathrm{L}^{-1}\right)\end{array}$ & $\begin{array}{c}{ }^{228} \mathrm{Ra}^{-1} \\
\left(\mathrm{mBq} \mathrm{L} \mathrm{L}^{-1}\right)\end{array}$ & ${ }^{228} \mathrm{Ra} /{ }^{226} \mathrm{Ra}$ & $\begin{array}{c}\text { Amônio } \\
\left.(\mu \mathrm{mol} \mathrm{L})^{-1}\right)\end{array}$ & $\begin{array}{c}\text { Nitrato } \\
\left.(\mu \mathrm{mol} \mathrm{L})^{-1}\right)\end{array}$ & $\begin{array}{c}\text { Nitrito } \\
\left.(\mu \mathrm{mol} \mathrm{L})^{-1}\right)\end{array}$ & $\begin{array}{c}\text { Silicato } \\
(\mu \mathrm{mol} \mathrm{L} \\
(-1)\end{array}$ & $\begin{array}{c}\text { Fosfato } \\
\left(\mu \mathrm{mol} \mathrm{L}^{-1}\right)\end{array}$ \\
\hline RIB 01 & $2,4 \pm 0,4$ & $25 \pm 2$ & 10,4 & 1,38 & 16,38 & 0,20 & 225,94 & 1,46 \\
\hline RIB 02 & $3,4 \pm 0,2$ & $17 \pm 1$ & 5,0 & 1,88 & 16,38 & 0,20 & 200,81 & 1,53 \\
\hline RIB 03 & $2,3 \pm 0,1$ & $19 \pm 1$ & 8,3 & 0,62 & 16,43 & 0,15 & 226,48 & 1,65 \\
\hline RIB 04 & $2,5 \pm 0,2$ & $29 \pm 2$ & 11,6 & 1,36 & 17,11 & 0,20 & 207,76 & 1,83 \\
\hline RIB 05 & $2,5 \pm 0,1$ & $18 \pm 1$ & 7,2 & 0,33 & 16,61 & 0,15 & 200,37 & 2,01 \\
\hline RIB 06 & $2,3 \pm 0,2$ & $19 \pm 1$ & 8,3 & 1,08 & 16,06 & 0,15 & 227,91 & 1,96 \\
\hline
\end{tabular}


TABELA 18 - Coordenadas geográficas das amostras de água de superfície do Rio Ribeira de Iguape (Agosto/ 2009).

\begin{tabular}{|c|c|c|c|c|c|c|c|c|c|c|}
\hline Amostras & Data da coleta & $\begin{array}{l}\text { Volume } \\
\text { (L) }\end{array}$ & $\begin{array}{c}\mathrm{T} \\
\left({ }^{\circ} \mathrm{C}\right)\end{array}$ & Latitude & Longitude & Salinidade & pH & $\begin{array}{c}\text { MES } \\
(\mathrm{mg} / \mathrm{L})\end{array}$ & $\begin{array}{c}\text { MO } \\
(\mathrm{mg} / \mathrm{L})\end{array}$ & $\begin{array}{c}\text { MO } \\
\%\end{array}$ \\
\hline RIB 01 & $23 / 08 / 2009$ & 5 & 18,0 & $24^{\circ} 41.570^{\prime} \mathrm{S}$ & $47^{\circ} 34.210^{\prime} \mathrm{W}$ & 0,03 & 6,933 & 19,3 & 5,8 & 29,9 \\
\hline RIB 02 & 23/08/2009 & 5 & 19,0 & $24^{\circ} 41.200^{\prime} \mathrm{S}$ & $47^{\circ} 33.770^{\prime} \mathrm{W}$ & 0,02 & 7,046 & 14,0 & 6,9 & 49,2 \\
\hline RIB 03 & 23/08/2009 & 5 & 17,0 & $24^{\circ} 39.440^{\prime} \mathrm{S}$ & $47^{\circ} 34.230^{\prime} \mathrm{W}$ & 0,02 & 7,158 & 18,9 & 5,3 & 28,2 \\
\hline RIB 04 & 23/08/2009 & 5 & 17,5 & $24^{\circ} 40.200^{\prime} \mathrm{S}$ & $47^{\circ} 33.900^{\prime} \mathrm{W}$ & 0,02 & 7,273 & 19,6 & 5,6 & 28,4 \\
\hline RIB 05 & $23 / 08 / 2009$ & 5 & 18,0 & $24^{\circ} 40.870^{\prime} \mathrm{S}$ & $47^{\circ} 35.850^{\prime} \mathrm{W}$ & 0,02 & 6,869 & 20,0 & 5,1 & 25,6 \\
\hline RIB 06 & 23/08/2009 & 5 & 18,0 & $24^{\circ} 40.200^{\prime} \mathrm{S}$ & $47^{\circ} 36.440^{\prime} \mathrm{W}$ & 0,02 & 6,859 & 26,7 & 6,7 & 25,0 \\
\hline
\end{tabular}

TABELA 19 - Concentração de isótopos naturais de Ra na águas de superfície do Rio Ribeira de Iguape (Agosto/ 2009).

\begin{tabular}{|c|c|c|c|c|c|c|c|c|}
\hline Amostras & $\begin{array}{c}{ }^{226} \mathrm{Ra} \\
\left(\mathrm{mBq} \mathrm{L}^{-1}\right)\end{array}$ & $\begin{array}{c}{ }^{228} \mathrm{Ra} \\
\left(\mathrm{mBq} \mathrm{L}^{-1}\right)\end{array}$ & ${ }^{228} \mathrm{Ra}^{226} / \mathrm{Ra}$ & $\begin{array}{c}\text { Amônio } \\
\left.(\mu \mathrm{mol} \mathrm{L})^{-1}\right)\end{array}$ & $\begin{array}{c}\text { Nitrato } \\
\left.(\mu \mathrm{mol} \mathrm{L})^{-1}\right)\end{array}$ & $\begin{array}{c}\text { Nitrito } \\
\left.(\mu \mathrm{mol} \mathrm{L})^{-1}\right)\end{array}$ & 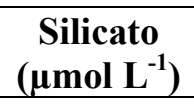 & $\begin{array}{c}\text { Fosfato } \\
\left.(\mu \mathrm{mol} \mathrm{L})^{-1}\right)\end{array}$ \\
\hline RIB 01 & $2,6 \pm 0,5$ & $18,0 \pm 0,5$ & 7,0 & 2,03 & 16,38 & 0,17 & 153,32 & 4,60 \\
\hline RIB 02 & $2,1 \pm 0,4$ & $24,0 \pm 0,7$ & 11,5 & 2,27 & 16,50 & 0,17 & 135,57 & 4,61 \\
\hline RIB 03 & $1,8 \pm 0,3$ & $19,0 \pm 0,8$ & 10,8 & 2,17 & 17,12 & 0,17 & 133,95 & 4,78 \\
\hline RIB 04 & $2,3 \pm 0,3$ & $21,0 \pm 5,0$ & 9,0 & 2,20 & 15,91 & 0,15 & 142,02 & 4,41 \\
\hline RIB 05 & $2,9 \pm 0,2$ & $19,0 \pm 0,8$ & 6,5 & 2,21 & 16,40 & 0,15 & 111,36 & 3,98 \\
\hline RIB 06 & $2,4 \pm 0,2$ & $21,5 \pm 0,1$ & 8,9 & 2,38 & 16,38 & 0,17 & 142,02 & 4,11 \\
\hline
\end{tabular}


TABELA 20 - Localização geográfica das amostras de água coletadas no Alto Vale do Ribeira, Iporanga, em Abril de 2009.

\begin{tabular}{lccccc}
\hline Origem das Amostras & $\begin{array}{c}\text { Data da } \\
\text { coleta }\end{array}$ & $\begin{array}{c}\text { Volume } \\
(\mathbf{L})\end{array}$ & $\mathbf{T}\left({ }^{\circ} \mathbf{C}\right)$ & Latitude & Longitude \\
\hline Caverna Santana (A1) & $28 / 04 / 2009$ & 5 & 19 & $24^{\circ} 31.510^{\prime} \mathrm{S}$ & $48^{\circ} 42.060^{\prime} \mathrm{W}$ \\
Caverna Água Suja (A2) & $28 / 04 / 2009$ & 5 & 19 & $24^{\circ} 31.250^{\prime} \mathrm{S}$ & $48^{\circ} 42.270^{\prime} \mathrm{W}$ \\
Cachoeira do Couto (A3) & $28 / 04 / 2009$ & 5 & 19 & $24^{\circ} 31.140^{\prime} \mathrm{S}$ & $48^{\circ} 41.430^{\prime} \mathrm{W}$ \\
Caverna Alambari de Baixo (A4) & $28 / 04 / 2009$ & 5 & 20 & $24^{\circ} 33.368^{\prime} \mathrm{S}$ & $48^{\circ} 39.888^{\prime} \mathrm{W}$ \\
Fonte na Estrada (A5) & $29 / 04 / 2009$ & 5 & 21 & $38^{\circ} 51.334^{\prime} \mathrm{S}$ & $94^{\circ} 47.941^{\prime} \mathrm{W}$ \\
Furnas (A6) & $29 / 04 / 2009$ & 5 & 19 & $24^{\circ} 32.253^{\prime} \mathrm{S}$ & $48^{\circ} 43.371^{\prime} \mathrm{W}$ \\
Água Potável - Núcleo Santana (A7) & $29 / 04 / 2009$ & 5 & 22 & $24^{\circ} 31.510^{\prime} \mathrm{S}$ & $48^{\circ} 42.060^{\prime} \mathrm{W}$ \\
\hline
\end{tabular}

TABELA 21 - Concentrações de atividade dos isótopos naturais de Ra nas amostras coletadas no Alto Vale do Ribeira, Iporanga, Abril de 2009.

\begin{tabular}{lccc}
\hline Origem da Amostra & $\begin{array}{c}{ }^{\mathbf{2 2 6}} \mathbf{R a} \\
\left(\mathbf{m B q} \mathbf{~ L}^{-\mathbf{1}}\right)\end{array}$ & $\begin{array}{c}{ }^{\mathbf{2 2 8}} \mathbf{R a} \\
\left(\mathbf{m B q} \mathbf{~ L}^{\mathbf{- 1}}\right)\end{array}$ & $\begin{array}{c}\text { Razão de Atividade } \\
{ }^{\mathbf{2 2 8}} \mathbf{R a} /{ }^{\mathbf{2 2 6}} \mathbf{R a}\end{array}$ \\
\hline Caverna Santana (A1) & $1,2 \pm 0,1$ & $22 \pm 1$ & \\
Caverna Água Suja (A2) & $2,1 \pm 0,1$ & $51 \pm 5$ & 24,0 \\
Cachoeira do Couto (A3) & $1,3 \pm 0,1$ & $16 \pm 1$ & 12,5 \\
Caverna Alambari de Baixo (A4) & $1,2 \pm 0,4$ & $18 \pm 2$ & 15,3 \\
Fonte na Estrada (A5) & $1,3 \pm 0,2$ & $19 \pm 2$ & 14,7 \\
Furnas (A6) & $1,6 \pm 0,7$ & $18 \pm 1$ & 11,0 \\
Água Potável - Núcleo Santana (A7) & $1,2 \pm 0,1$ & $19 \pm 1$ & 15,9 \\
\hline
\end{tabular}


TABELA 22 - Localização geográfica das amostras de água coletadas no Alto Vale do Ribeira, Núcleo Caboclos, Setembro de 2009.

\begin{tabular}{|c|c|c|c|c|c|}
\hline Origem das Amostras & Data da coleta & $\begin{array}{l}\text { Volume } \\
\text { (L) }\end{array}$ & $\begin{array}{c}\mathrm{T} \\
\left({ }^{\circ} \mathrm{C}\right)\end{array}$ & Latitude & Longitude \\
\hline Trilha Casa de Pedra (A8) & $26 / 09 / 2009$ & 2 & - & $24^{\circ} 26.416^{\prime} \mathrm{S}$ & $48^{\circ} 35.086^{\prime} \mathrm{W}$ \\
\hline $\begin{array}{l}\text { Trilha Casa de Pedra Venda do } \\
\text { Betão (A9) }\end{array}$ & 26/09/2009 & 2 & - & $24^{\circ} 26.933^{\prime} \mathrm{S}$ & $48^{\circ} 35.078^{\prime} \mathrm{W}$ \\
\hline $\begin{array}{l}\text { Trilha Casa de Pedra, depois do } \\
\text { desmoronamento de calcário (A10) }\end{array}$ & 26/09/2009 & 2 & - & $24^{\circ} 27.077^{\prime} \mathrm{S}$ & $48^{\circ} 35.558^{\prime} \mathrm{W}$ \\
\hline $\begin{array}{l}\text { Rio do Chapéu, próximo a igrejinha } \\
\text { (A11) }\end{array}$ & 26/09/2009 & 2 & 16,0 & $24^{\circ} 26.194^{\prime} \mathrm{S}$ & $48^{\circ} 35.243^{\prime} \mathrm{W}$ \\
\hline Gruta Chapéu Mirim I (A12) & $26 / 09 / 2009$ & 2 & - & $24^{\circ} 24.033^{\prime} \mathrm{S}$ & $48^{\circ} 35.098^{\prime} \mathrm{W}$ \\
\hline Rio Iporanga (A13) & $27 / 09 / 2009$ & 2 & 17,0 & $24^{\circ} 27.263^{\prime} \mathrm{S}$ & $48^{\circ} 37.553^{\prime} \mathrm{W}$ \\
\hline $\begin{array}{l}\text { Rio ao lado da mina de chumbo } \\
\text { Mina Espírito Santo (A14) }\end{array}$ & $27 / 09 / 2009$ & 2 & 19,5 & $24^{\circ} 27.134^{\prime} \mathrm{S}$ & $48^{\circ} 37.041^{\prime} \mathrm{W}$ \\
\hline $\begin{array}{l}\text { Rio do Chapéu, Garganta do Diabo, } \\
\text { ao lado da mina de calcário (A15) }\end{array}$ & $27 / 09 / 2009$ & 2 & 20,0 & $24^{\circ} 26.407^{\prime} \mathrm{S}$ & $48^{\circ} 36.573^{\prime} \mathrm{W}$ \\
\hline $\begin{array}{l}\text { Casa início da trilha, Rio da } \\
\text { Montanha da Dúvida (A16) }\end{array}$ & 27/09/2009 & 2 & 20,5 & $24^{\circ} 26.316^{\prime} \mathrm{S}$ & $48^{\circ} 36.337^{\prime} \mathrm{W}$ \\
\hline Rio Pescaria (A17) & 27/09/2009 & 2 & - & $24^{\circ} 24.418^{\prime} \mathrm{S}$ & $48^{\circ} 34.055^{\prime} \mathrm{W}$ \\
\hline Gruta do Chapéu (A18) & $27 / 09 / 2009$ & 2 & 17,0 & $24^{\circ} 26.061^{\prime} \mathrm{S}$ & $48^{\circ} 35.246^{\prime} \mathrm{W}$ \\
\hline Caverna das Aranhas (A19) & $27 / 09 / 2009$ & 2 & 18,0 & $24^{\circ} 35.246^{\prime} \mathrm{S}$ & $48^{\circ} 35.246^{\prime} \mathrm{W}$ \\
\hline
\end{tabular}


TABELA 23 - Concentrações de atividade dos isótopos naturais de Ra nas amostras coletadas no Alto Vale do Ribeira, Núcleo Caboclos, Setembro de 2009.

\begin{tabular}{|c|c|c|c|}
\hline Origem da Amostra & $\begin{array}{c}{ }^{226} \mathrm{Ra} \\
\left(\mathrm{mBq} \mathbf{L}^{-1}\right)\end{array}$ & $\begin{array}{c}{ }^{228} \mathbf{R a} \\
\left(\mathrm{mBq} \mathbf{L}^{-1}\right)\end{array}$ & $\begin{array}{c}\text { Razão de } \\
\text { Atividade } \\
{ }^{228} \mathrm{Ra} /{ }^{226} \mathbf{R a}\end{array}$ \\
\hline Trilha Casa de Pedra (A8) & $5,4 \pm 0,1$ & $40 \pm 2$ & 7,4 \\
\hline Trilha Casa de Pedra Venda do Betão (A9) & $3,3 \pm 0,2$ & $43 \pm 1$ & 13,1 \\
\hline $\begin{array}{l}\text { Trilha Casa de Pedra, depois do } \\
\text { desmoronamento de calcário (A10) }\end{array}$ & $4,8 \pm 0,2$ & $52 \pm 1$ & 10,9 \\
\hline Rio do Chapéu, próximo a igrejinha (A11) & $5,7 \pm 0,5$ & $46 \pm 1$ & 8,1 \\
\hline Gruta Chapéu Mirim I (A12) & $6,3 \pm 0,1$ & $46 \pm 2$ & 7,3 \\
\hline Rio Iporanga (A13) & $3,3 \pm 0,3$ & $45 \pm 1$ & 13,5 \\
\hline $\begin{array}{l}\text { Rio ao lado da mina de chumbo Mina Espírito } \\
\text { Santo (A14) }\end{array}$ & $5,6 \pm 0,2$ & $51 \pm 1$ & 9,0 \\
\hline $\begin{array}{l}\text { Rio do Chapéu, Garganta do Diabo, ao lado da } \\
\text { mina de calcário (A15) }\end{array}$ & $5,1 \pm 0,3$ & $79 \pm 2$ & 15,5 \\
\hline $\begin{array}{l}\text { Casa início da trilha, Rio da Montanha da } \\
\text { Dúvida (A16) }\end{array}$ & $5,2 \pm 0,2$ & $56 \pm 2$ & 10,8 \\
\hline Rio Pescaria (A17) & $3,8 \pm 0,4$ & $43 \pm 1$ & 11,4 \\
\hline Gruta do Chapéu (A18) & $4,9 \pm 0,1$ & $45 \pm 1$ & 9,1 \\
\hline Caverna das Aranhas (A19) & $5,2 \pm 0,2$ & $62 \pm 1$ & 11,9 \\
\hline
\end{tabular}


TABELA 24 - Localização geográfica das amostras de água coletadas no Alto Vale do Ribeira, Núcleo Areado, Outubro de 2009.

\begin{tabular}{lccccc}
\hline Origem das Amostras & Data da coleta & $\begin{array}{c}\text { Volume } \\
(\mathbf{L})\end{array}$ & $\mathbf{T}\left({ }^{\circ} \mathbf{C}\right)$ & Latitude & Longitude \\
& & & & & \\
\hline A20 & $23 / 10 / 2009$ & 2 & 18,0 & $24^{\circ} 19.054^{\prime} \mathrm{S}$ & $48^{\circ} 35.183^{\prime} \mathrm{W}$ \\
$\mathbf{A 2 1}$ & $23 / 10 / 2009$ & 2 & 19,0 & $24^{\circ} 19.073^{\prime} \mathrm{S}$ & $48^{\circ} 35.175^{\prime} \mathrm{W}$ \\
$\mathbf{A 2 2}$ & $23 / 10 / 2009$ & 2 & 23,0 & $24^{\circ} 20.134^{\prime} \mathrm{S}$ & $48^{\circ} 36.053^{\prime} \mathrm{W}$ \\
$\mathbf{A 2 3}$ & $24 / 10 / 2009$ & 2 & 16,5 & $24^{\circ} 20.002^{\prime} \mathrm{S}$ & $48^{\circ} 36.016^{\prime} \mathrm{W}$ \\
\hline
\end{tabular}

TABELA 25 - Concentrações de atividade dos isótopos naturais de $\mathrm{Ra}$ nas amostras coletadas no Alto Vale do Ribeira, Núcleo Areado, Outubro de 2009.

\begin{tabular}{lccc}
\hline Origem da Amostra & $\begin{array}{c}{ }^{\mathbf{2 2 6}} \mathbf{R a} \\
\left(\mathbf{m B q} \mathbf{~ L}^{-\mathbf{1}}\right)\end{array}$ & $\begin{array}{c}{ }^{\mathbf{2 2 8}} \mathbf{R a} \\
\left(\mathbf{m B q} \mathbf{~ L}^{\mathbf{- 1}}\right)\end{array}$ & $\begin{array}{c}\text { Razão de } \\
\text { Atividade } \\
{ }^{\mathbf{2 2 8}_{\mathbf{R a}} /{ }^{\mathbf{2 2 6}} \mathbf{R a}}\end{array}$ \\
\hline $\mathbf{A 2 0}$ & $6,8 \pm 0,2$ & $52 \pm 1$ & 7,7 \\
$\mathbf{A 2 1}$ & $3,2 \pm 0,1$ & $46 \pm 2$ & 14,2 \\
$\mathbf{A 2 2}$ & $3,8 \pm 0,4$ & $43 \pm 1$ & 11,2 \\
$\mathbf{A 2 3}$ & $3,4 \pm 0,2$ & $43 \pm 1$ & 12,6 \\
\hline
\end{tabular}


TABELA 26 - Localização geográfica das amostras de água coletadas no Alto Vale do Ribeira, Núcleo Bulhas D’Água, Outubro de 2009.

\begin{tabular}{lccccc}
\hline Origem das Amostras & Data da coleta & $\begin{array}{c}\text { Volume } \\
(\mathbf{L})\end{array}$ & $\mathbf{T}\left({ }^{\circ} \mathbf{C}\right)$ & Latitude & Longitude \\
\hline A24 & $24 / 10 / 2009$ & 2 & 20,0 & $24^{\circ} 20.149^{\prime} \mathrm{S}$ & $48^{\circ} 30.589^{\prime} \mathrm{W}$ \\
$\mathbf{A 2 5}$ & $24 / 10 / 2009$ & 2 & 19,0 & $24^{\circ} 20.042^{\prime} \mathrm{S}$ & $48^{\circ} 30.353^{\prime} \mathrm{W}$ \\
$\mathbf{A 2 6}$ & $24 / 10 / 2009$ & 2 & 19,5 & $24^{\circ} 20.156^{\prime} \mathrm{S}$ & $48^{\circ} 30.060^{\prime} \mathrm{W}$ \\
$\mathbf{A 2 7}$ & $25 / 10 / 2009$ & 2 & 18,7 & $24^{\circ} 20.130^{\prime} \mathrm{S}$ & $48^{\circ} 30.055^{\prime} \mathrm{W}$ \\
$\mathbf{A 2 8}$ & $25 / 10 / 2009$ & 2 & 21,0 & $24^{\circ} 18.549^{\prime} \mathrm{S}$ & $48^{\circ} 30.030^{\prime} \mathrm{W}$ \\
\hline
\end{tabular}

TABELA 27 - Concentrações de atividade dos isótopos naturais de Ra nas amostras coletadas no Alto Vale do Ribeira, Núcleo Bulhas D’Água, Outubro de 2009.

\begin{tabular}{lccc}
\hline Origem da Amostra & $\begin{array}{c}{ }^{\mathbf{2 2 6}} \mathbf{R a} \\
\left(\mathbf{m B q} \mathbf{L}^{-\mathbf{1}}\right)\end{array}$ & $\begin{array}{c}{ }^{\mathbf{2 2 8}} \mathbf{R a} \\
\left(\mathbf{m B q} \mathbf{L}^{\mathbf{- 1}}\right)\end{array}$ & $\begin{array}{c}\text { Razão de } \\
\text { Atividade } \\
{ }^{\mathbf{2 2 8}} \mathbf{R a} /{ }^{226} \mathbf{R a}\end{array}$ \\
\hline $\mathbf{A 2 4}$ & $2,5 \pm 0,2$ & $41 \pm 1$ & 14,9 \\
$\mathbf{A 2 5}$ & $4,1 \pm 0,5$ & $45 \pm 1$ & 11,1 \\
$\mathbf{A 2 6}$ & $3,1 \pm 0,2$ & $41 \pm 1$ & 13,1 \\
$\mathbf{A 2 7}$ & $11 \pm 1$ & $43 \pm 1$ & 3,9 \\
$\mathbf{A 2 8}$ & $3,8 \pm 0,2$ & $40 \pm 1$ & 10,5 \\
\hline
\end{tabular}


TABELA 28 - Concentrações de atividade dos isótopos naturais de Ra nas amostras coletadas no Alto Vale do Ribeira, Núcleo Santana, Novembro de 2009.

\begin{tabular}{lccc}
\hline Origem da Amostra & $\begin{array}{c}{ }^{\mathbf{2 2 6}} \mathbf{R a} \\
\left(\mathbf{m B q} \mathbf{L}^{-\mathbf{1}}\right)\end{array}$ & $\begin{array}{c}{ }^{\mathbf{2 2 8}} \mathbf{R a} \\
\left(\mathbf{m B q} \mathbf{L}^{-\mathbf{1}}\right)\end{array}$ & $\begin{array}{c}\text { Razão de } \\
\text { Atividade } \\
{ }^{\mathbf{2 2 8}} \mathbf{R a} /{ }^{\mathbf{2 2 6}} \mathbf{R a}\end{array}$ \\
\hline $\mathbf{A 2 9}$ & 0,17 & 0,60 & 3,5 \\
$\mathbf{A 3 0}$ & 0,06 & 0,76 & 12,7 \\
$\mathbf{A 3 1}$ & 0,06 & 0,74 & 12,3 \\
$\mathbf{A 3 2}$ & 0,06 & 0,71 & 11,8 \\
$\mathbf{A 3 3}$ & 0,09 & 0,66 & 7,3 \\
\hline
\end{tabular}

TABELA 29 - Concentrações de atividade dos isótopos naturais de Ra nas amostras coletadas no Alto Vale do Ribeira, Núcleo Ouro Grosso, Novembro de 2009.

\begin{tabular}{lccc}
\hline Origem da Amostra & $\begin{array}{c}{ }^{226} \mathbf{R a} \\
\left(\mathbf{m B q ~} \mathbf{L}^{-1}\right)\end{array}$ & $\begin{array}{c}{ }^{228} \mathbf{R a} \\
\left(\mathbf{m B q ~} \mathbf{L}^{-1}\right)\end{array}$ & $\begin{array}{c}\text { Razão de } \\
\text { Atividade } \\
{ }^{\mathbf{2 2 8}} \mathbf{R a} /{ }^{\mathbf{2 2 6}} \mathbf{R a}\end{array}$ \\
\hline A34 & 0,06 & 0,63 & 10,5 \\
A35 & 0,14 & 0,63 & 4,5 \\
A36 & 0,09 & 1,04 & 11,5 \\
\hline
\end{tabular}

Como mencionado no Capítulo 5, as campanhas de amostragem foram realizadas em 2009 e 2010. De todas as coletas, as campanhas em que se obtiveram os maiores conjuntos de amostras foram as correspondentes ao período de 10 a 12 de Fevereiro 2009 e de 19 a 21 de Agosto de 2009. A verificação da precipitação pluviométrica ocorrida nestas duas fases é de grande importância, uma vez que, esses índices pluviométricos podem interferir na distribuição dos radionuclídeos naturais presentes nas águas superficiais e subterrâneas da região de interesse. Os acúmulos de chuva ocorridos no ano de 2009 podem ser observados na FIG. 23. A figura evidencia que houve um grande acúmulo de chuvas no mês de Fevereiro/09 na região Sul do Estado de São Paulo, com aproximadamente $500 \mathrm{~mm}$ no mês correspondente. 


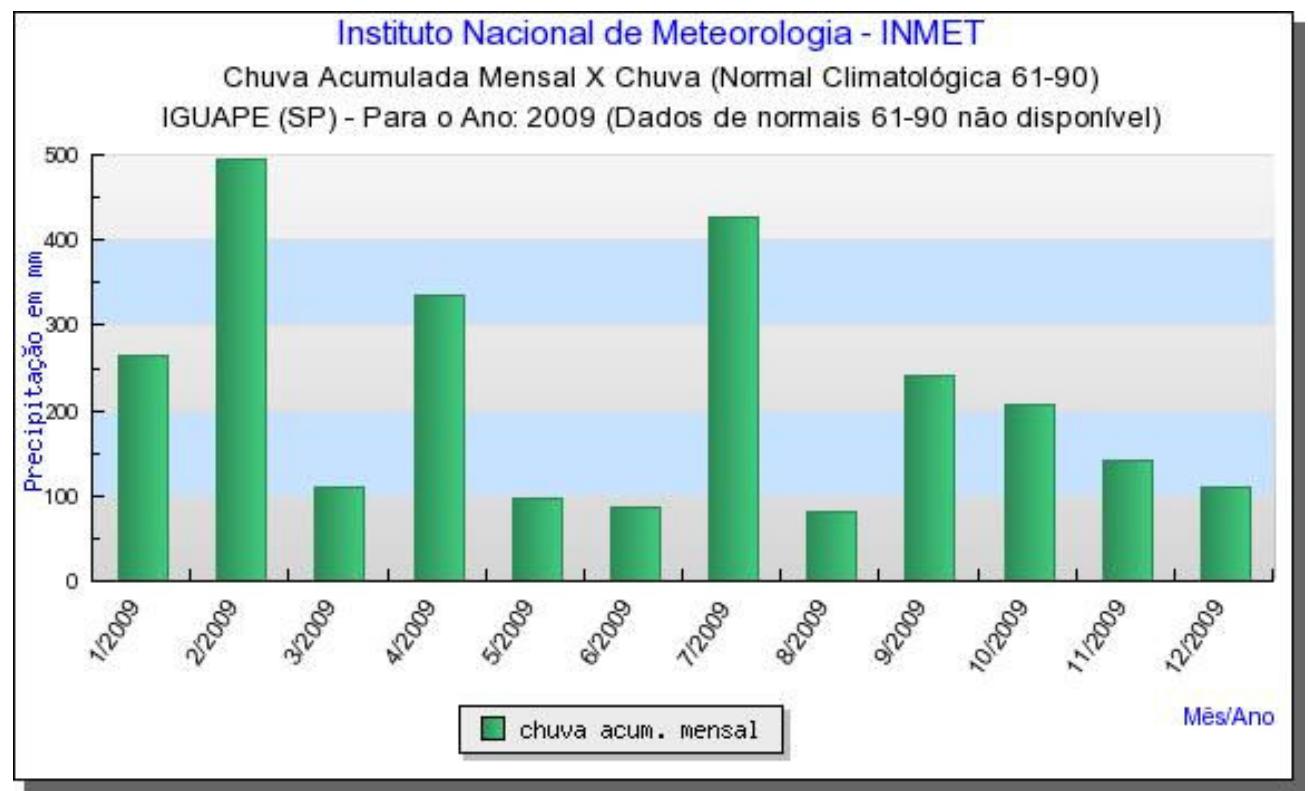

FIGURA 23 - Índice mensal das precipitações ocorridas em 2009 (INMET, 2010).

Nas FIG. 24 e 25 é possível observar com maior detalhe as distribuições de chuvas ocorridas durante os meses de Fevereiro e Agosto de 2009, verificando-se que nos períodos em que foram realizadas as coletas das amostras de água em Fevereiro (10 a 12 /02/2009) houve menor precipitação em comparação com o período do mês de Agosto (19 a 21/09/2009).

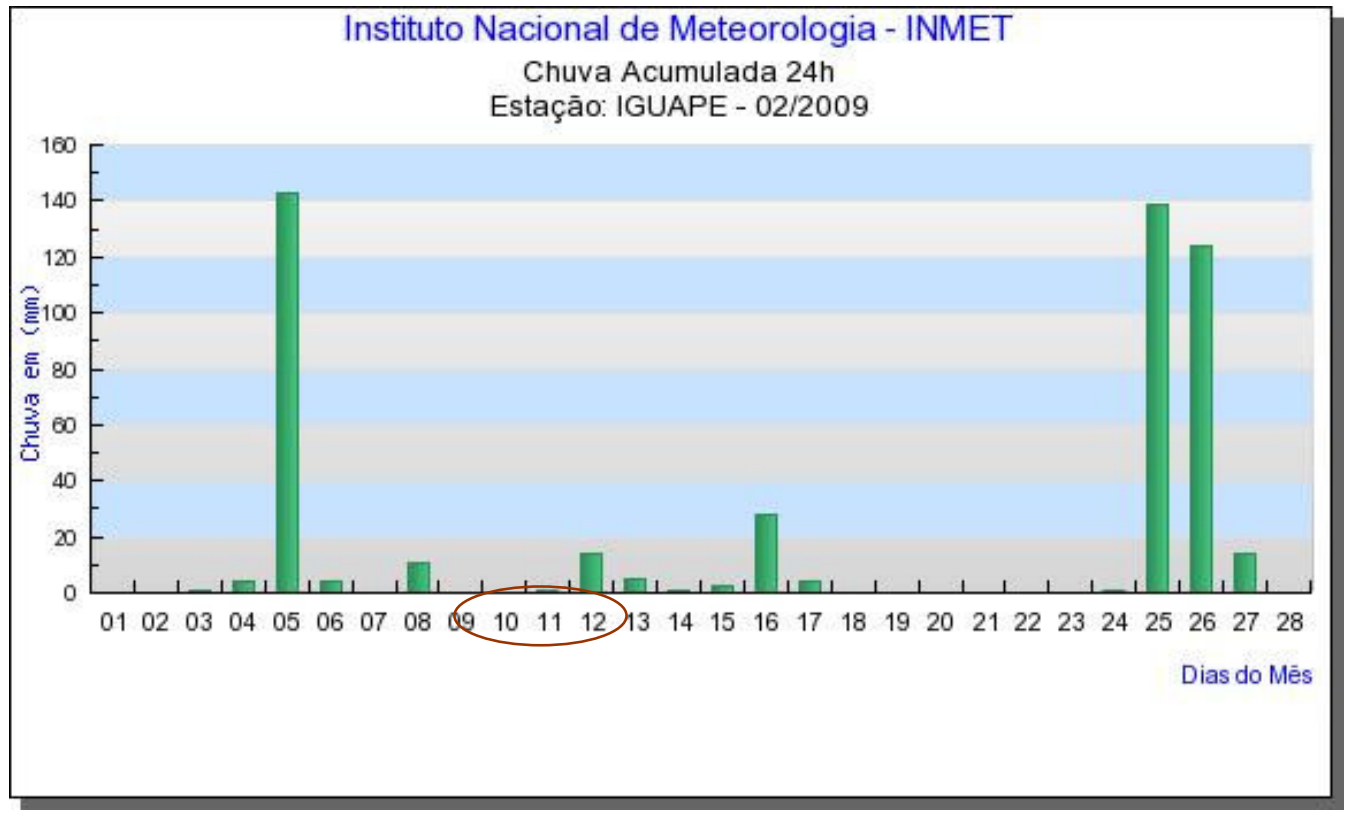

FIGURA 24 - Acúmulo das chuvas ocorridas no mês de Fevereiro de 2009 (INMET, 2010). 


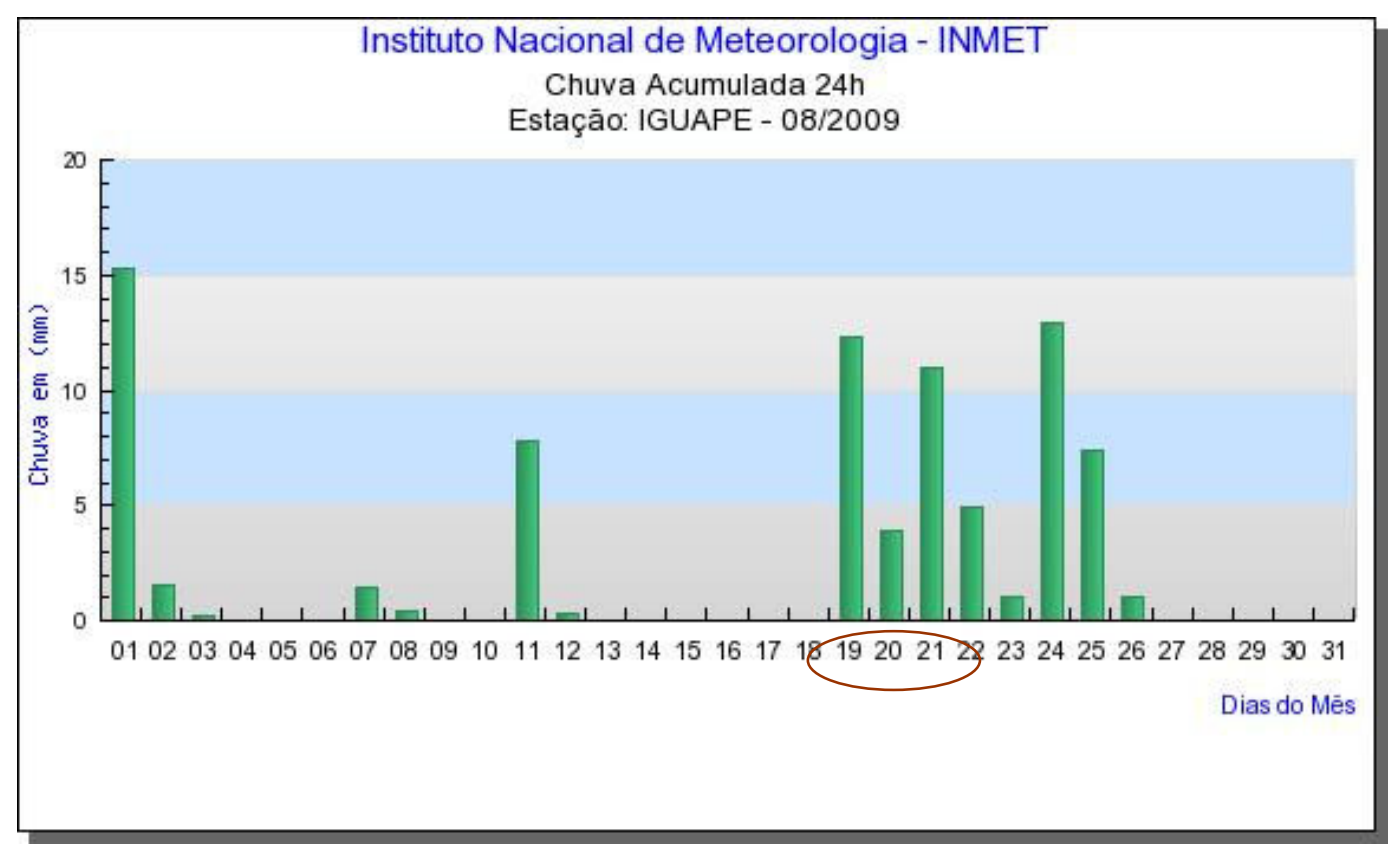

FIGURA 25 - Acúmulo das chuvas ocorridas no mês de Agosto de 2009 (INMET, 2010).

As FIG. 26 a 30 apresentam as distribuições dos isótopos naturais de Ra nas águas de superfície do sistema estuarino Cananéia-Iguape e no Rio Ribeira de Iguape, nas águas subterrâneas das regiões de Cananéia, Ilha Comprida e Iguape, como também águas de superfície e águas subterrâneas da região do Alto Vale do Ribeira. As FIG. 31 a 33 mostram a distribuição das concentrações de ${ }^{226} \mathrm{Ra}$ e ${ }^{228} \mathrm{Ra}$ em função da salinidade em todos os cenários estudados.

Nas FIG. 34 a 39 pode-se observar a distribuição das atividades de ${ }^{226} \mathrm{Ra}$ e ${ }^{228} \mathrm{Ra}$ em função das concentrações de material em suspensão (MES) e matéria orgânica (MO) nas águas do sistema estuarino Cananéia-Iguape e no Rio Ribeira de Iguape. As FIG. 40 a 47 ilustram a distribuição de nutrientes principais nas amostras de água ensaiadas no escopo deste projeto, enquanto as FIG. 48 a 59 finalmente apresentam as distribuições de ${ }^{226} \mathrm{Ra}$ e de ${ }^{228} \mathrm{Ra}$ em função das concentrações de nutrientes principais nitrito, nitrato, fosfato, silicato e amônio. 


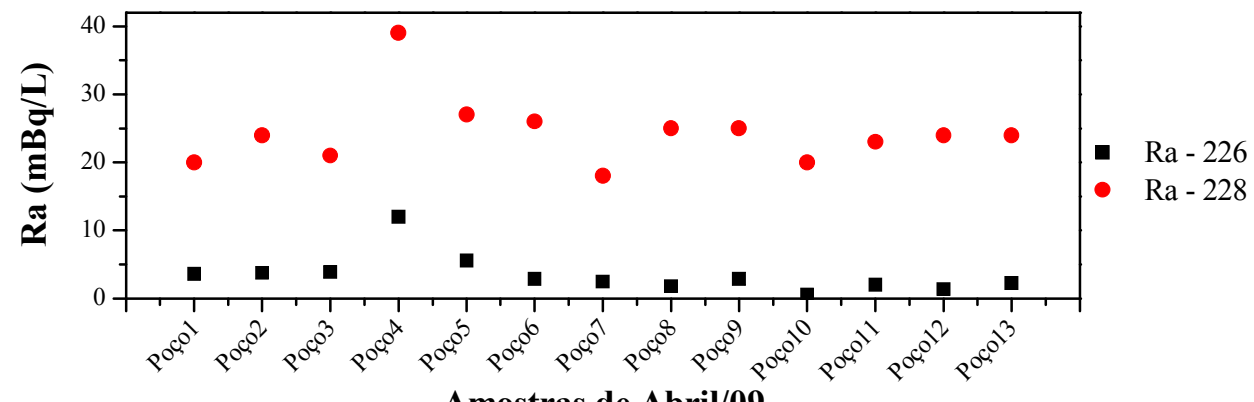

Amostras de Abril/09

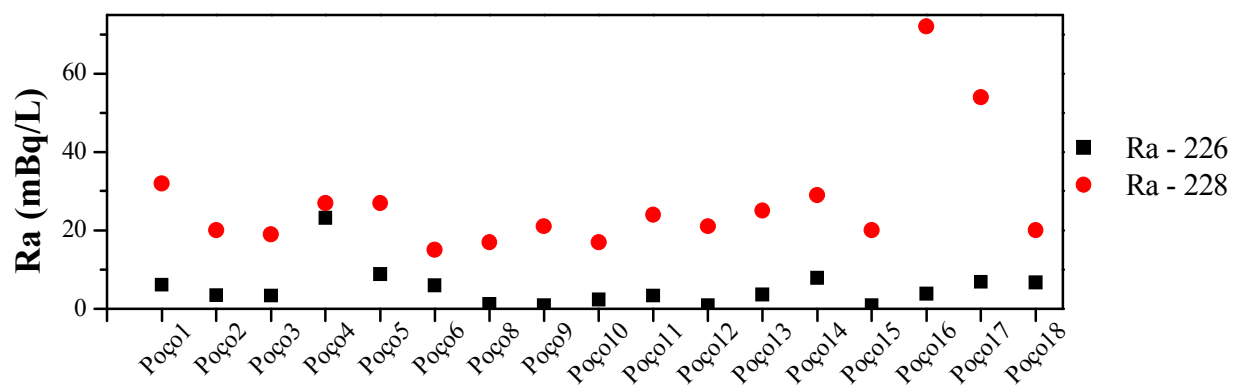

Amostras de Agosto/09

FIGURA 26 - Distribuição das concentrações de atividade dos isótopos naturais de Ra nas águas subterrâneas de Cananéia, Iguape e Ilha Comprida em Abril/09 e Agosto/09.

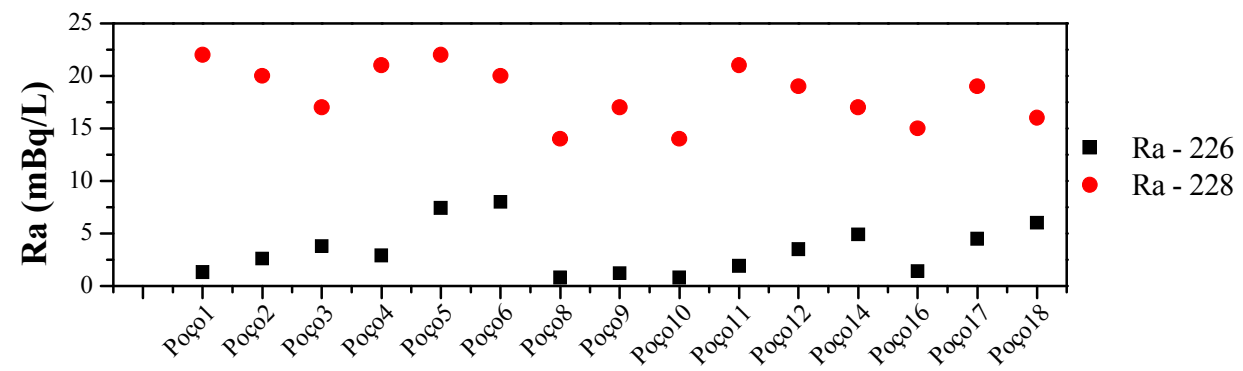

Amostras de Abril/10

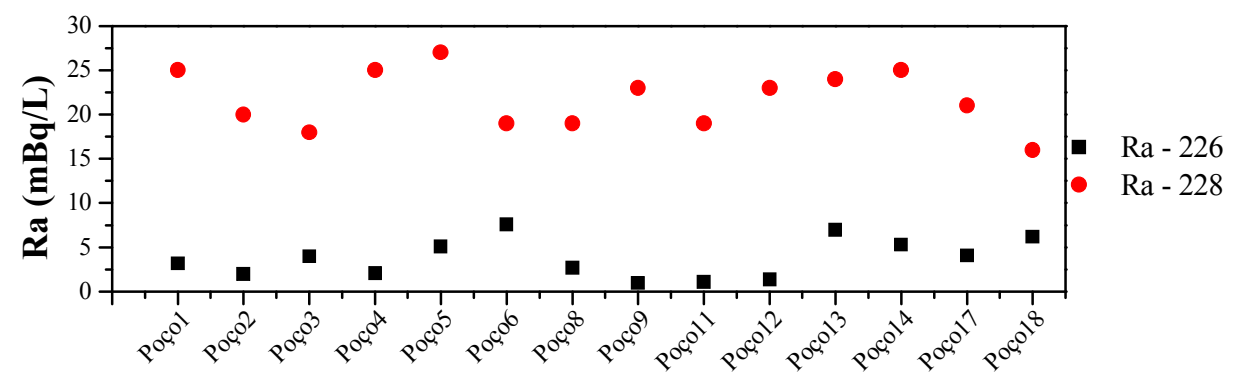

Amostras de Maio/10

FIGURA 27 - Distribuição das concentrações de atividade dos isótopos naturais de Ra nas águas subterrâneas de Cananéia, Iguape e Ilha Comprida em Abril/10 e Maio/10. 

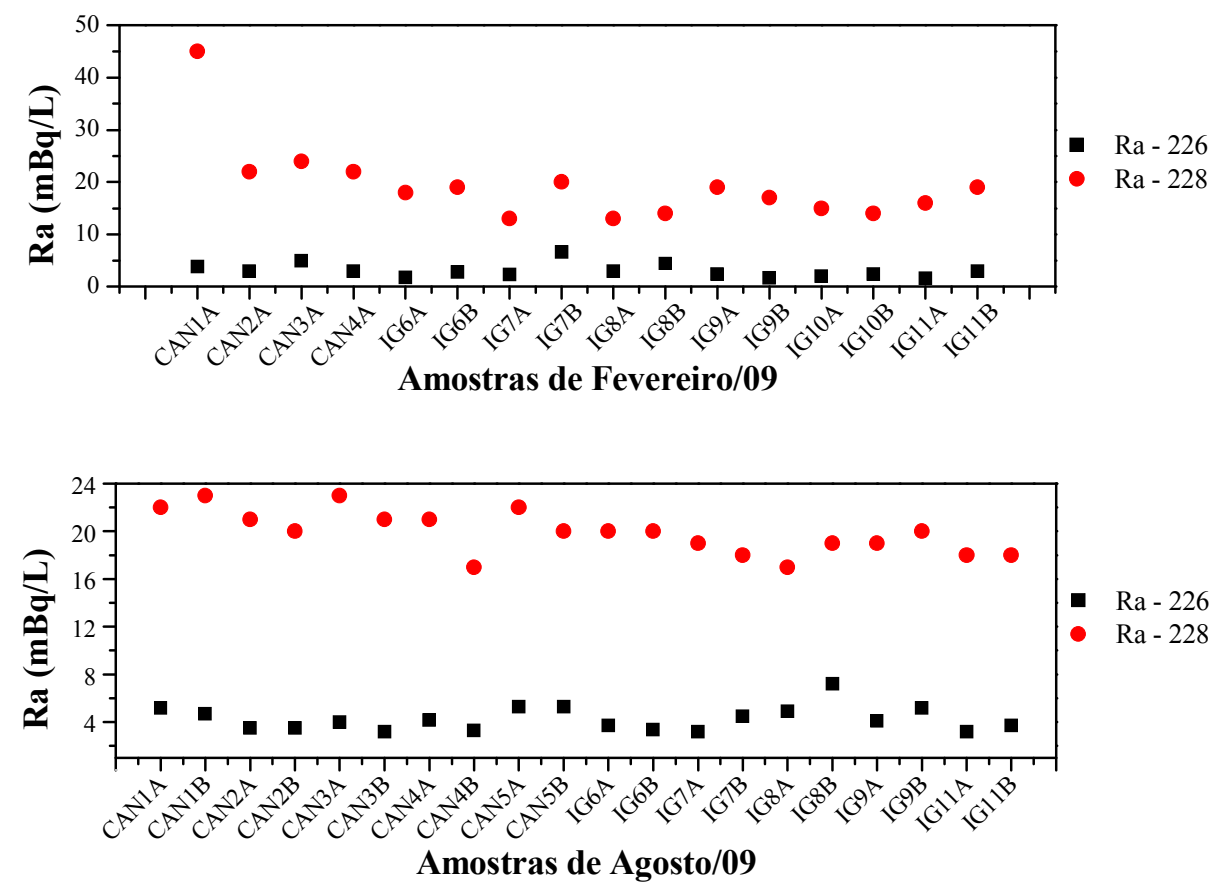

FIGURA 28 - Distribuição das concentrações de atividade dos isótopos naturais de Ra nas estações hidroquímicas do sistema estuarino Cananéia-Iguape em Fevereiro/09 e Agosto/09.
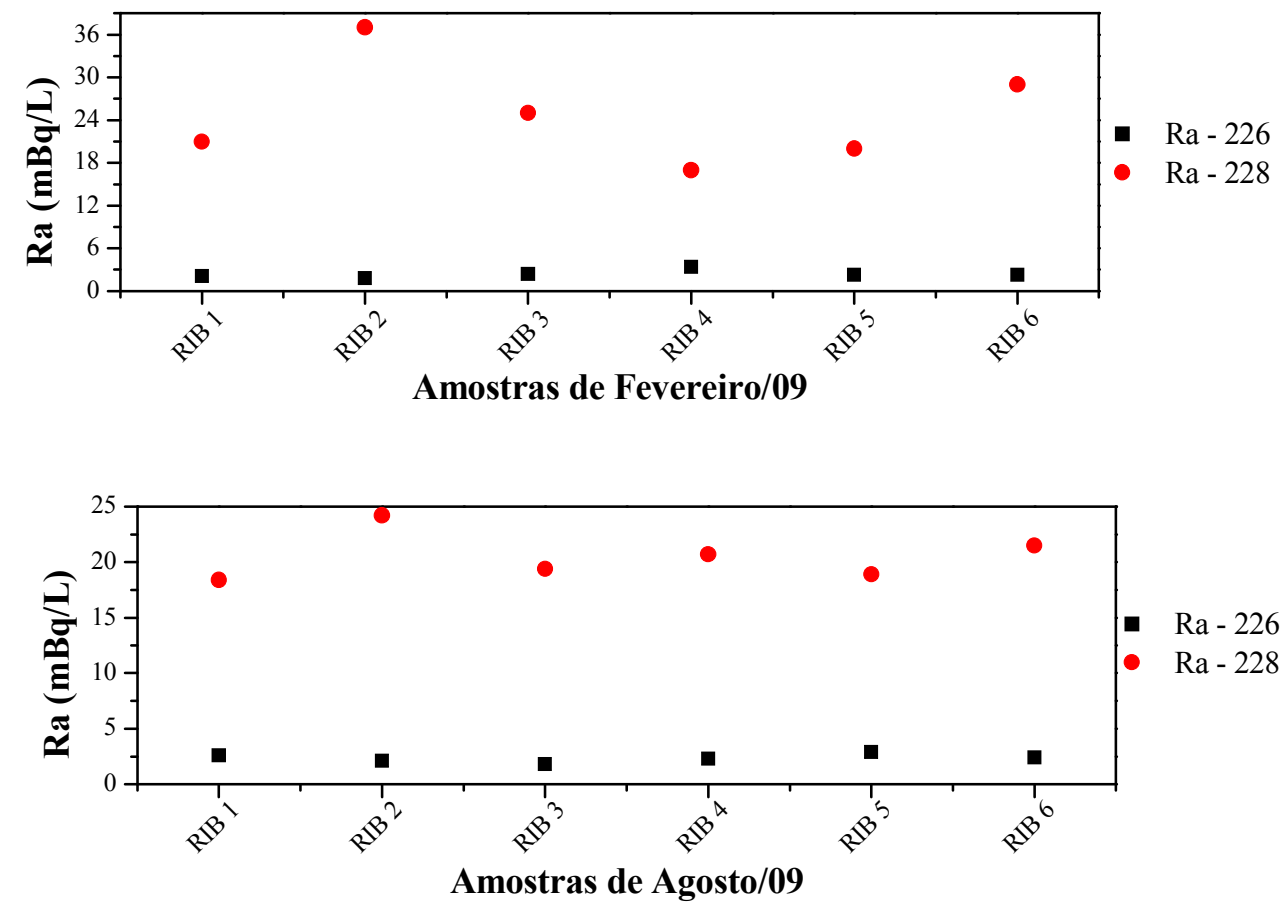

FIGURA 29 - Distribuição das concentrações de atividade dos isótopos naturais de Ra no Rio Ribeira de Iguape em Fevereiro/09 e Agosto/09. 

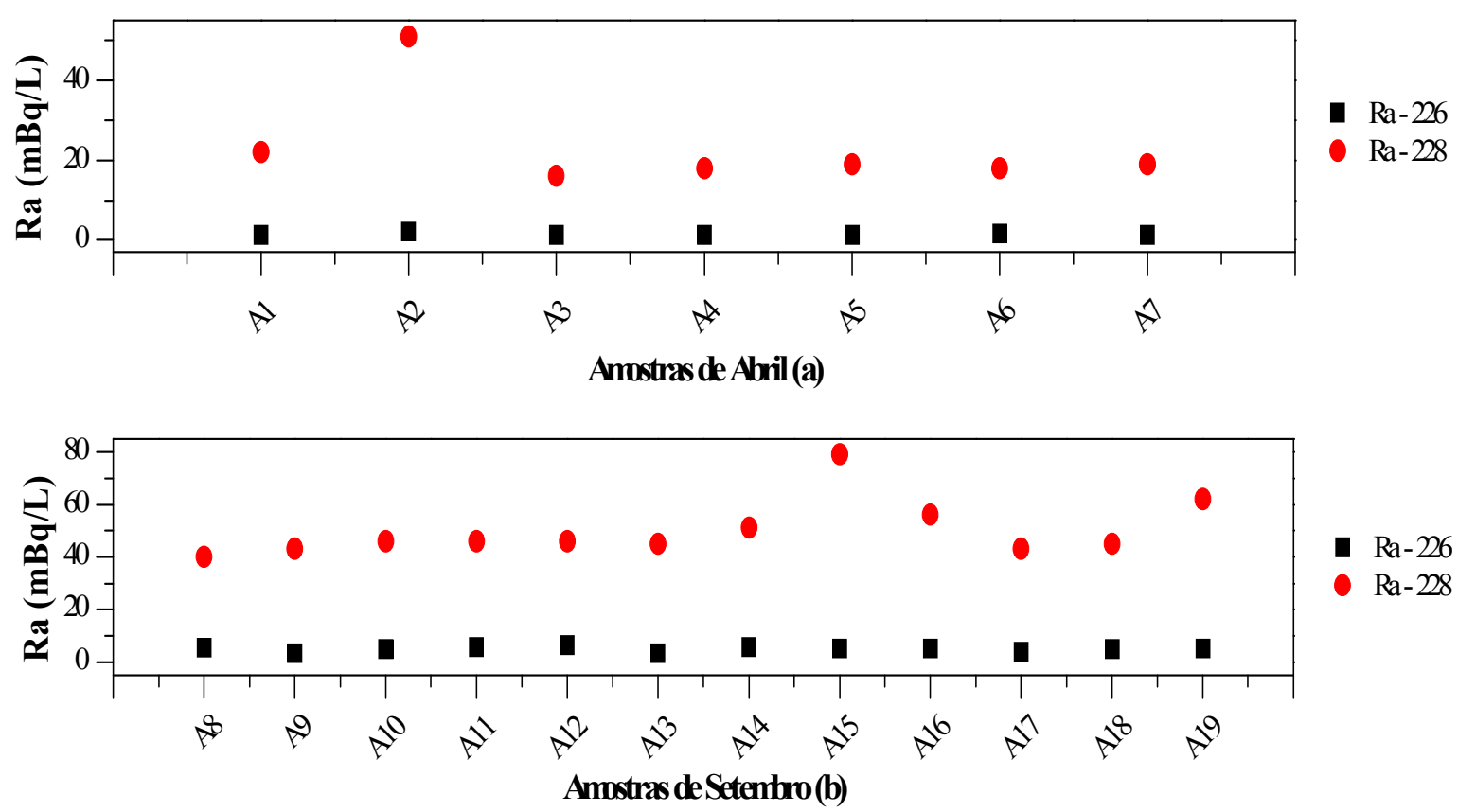

$\mathrm{Ra}-226$

- $\mathrm{Ra}-228$

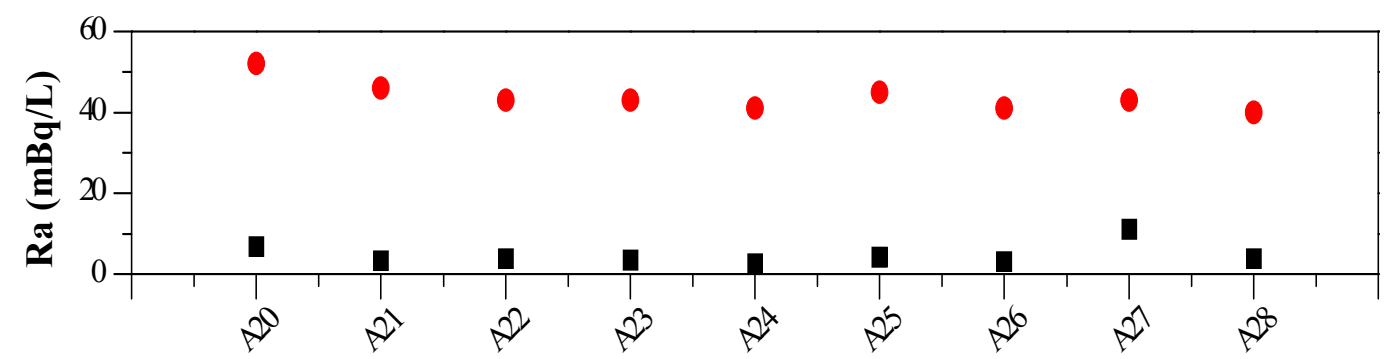

Ra-226

- $\mathrm{Ra}-228$

Amostras dede Outubro(c)

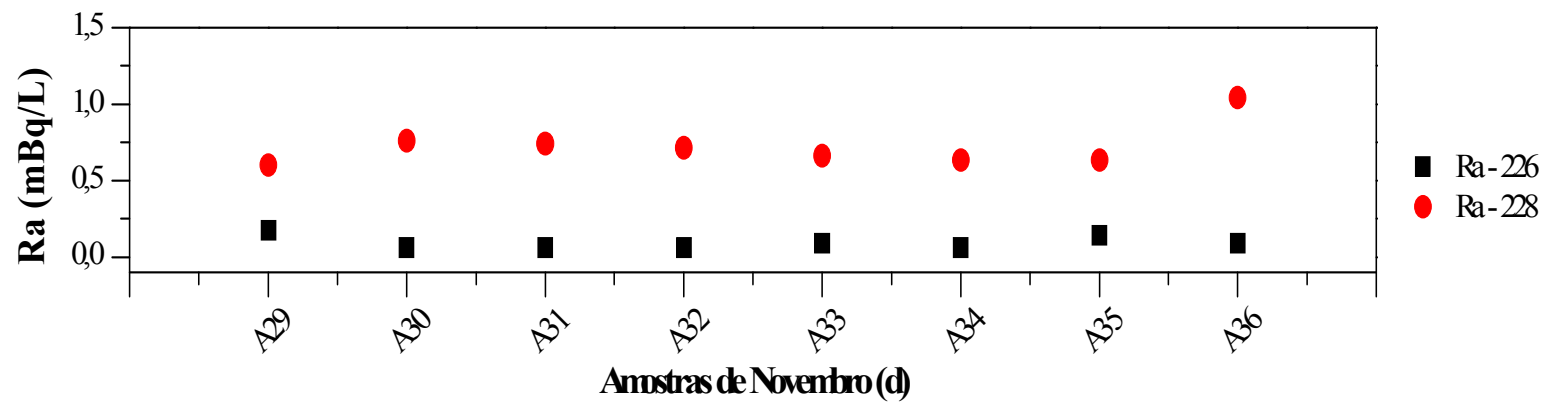

FIGURA 30 - Distribuição das concentrações de atividade dos isótopos naturais de Ra no Alto Vale do Ribeira em: Iporanga (a), Núcleo Caboclos (b), Núcleos Areado e Bulhas D’Água (c), Núcleos Ouro Grosso e Santana (d), de Abril/09 a Novembro/09. 

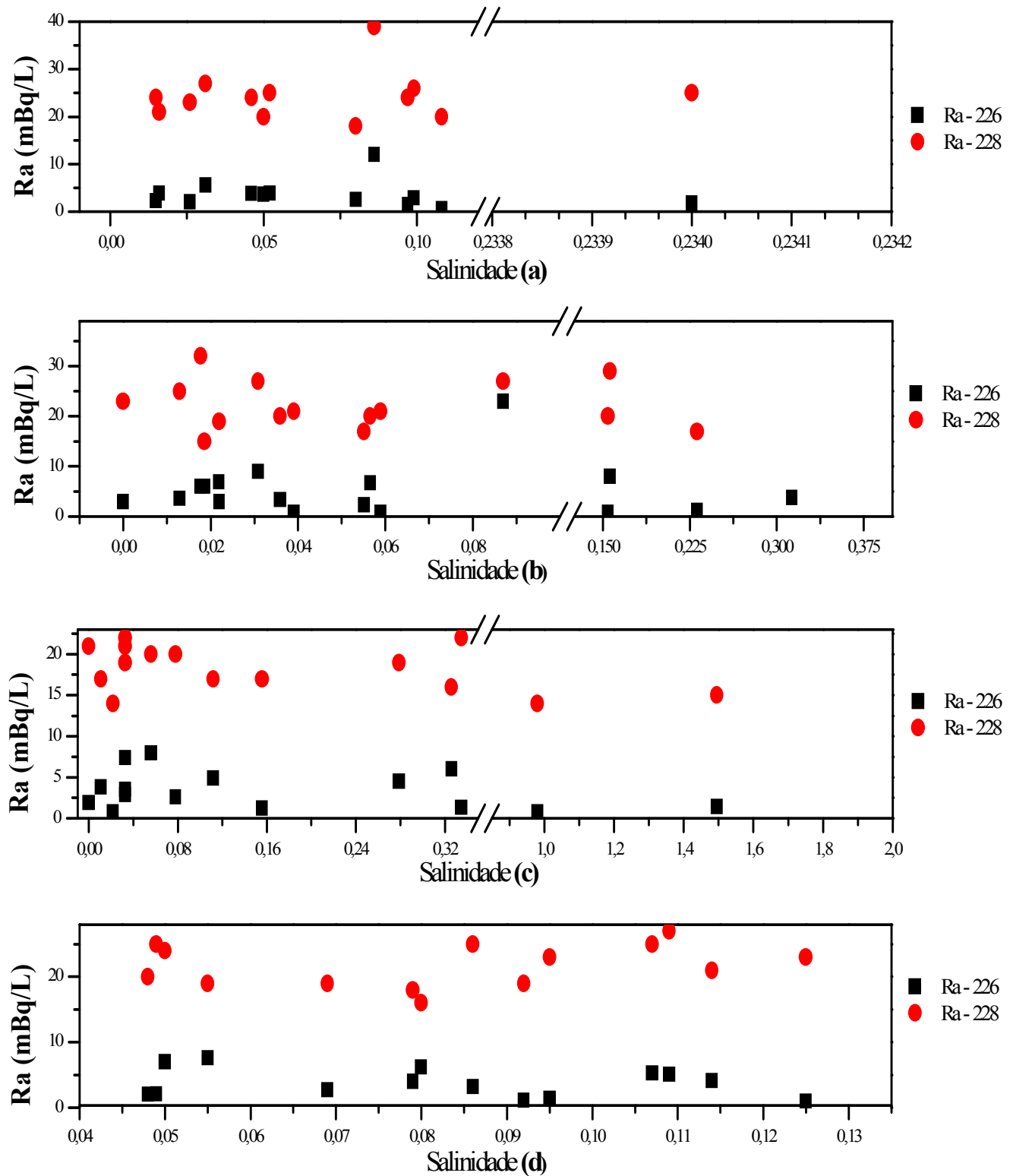

FIGURA 31 - Distribuição das concentrações de atividade dos isótopos naturais de Ra em função da salinidade observada nas amostras de água subterrânea de Cananéia, Iguape e Ilha Comprida em Abril/09 (a), Agosto/09 (b), Abril/10 (c) e Maio/10 (d). 

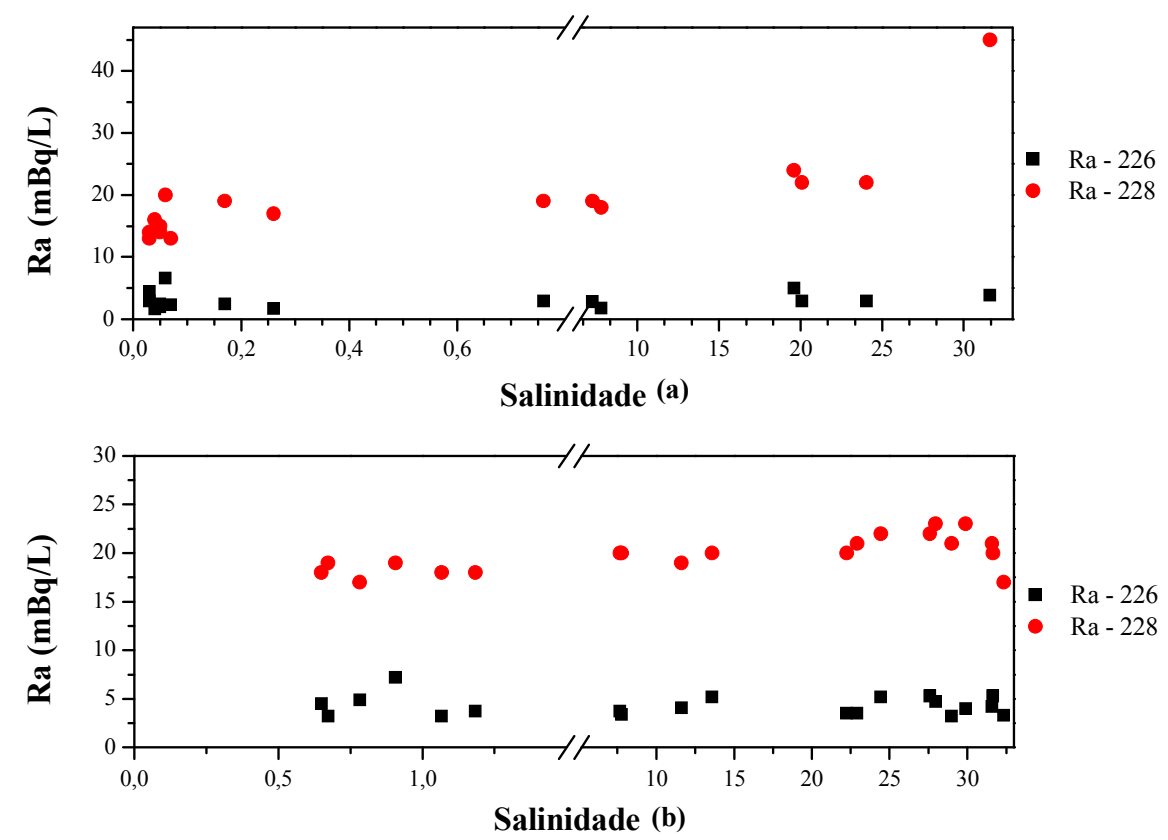

FIGURA 32 - Distribuição das concentrações de atividade dos isótopos naturais de Ra em função da salinidade nas estações hidroquímicas do sistema estuarino Cananéia-Iguape em Fevereiro/09 (a) e Agosto/09 (b).
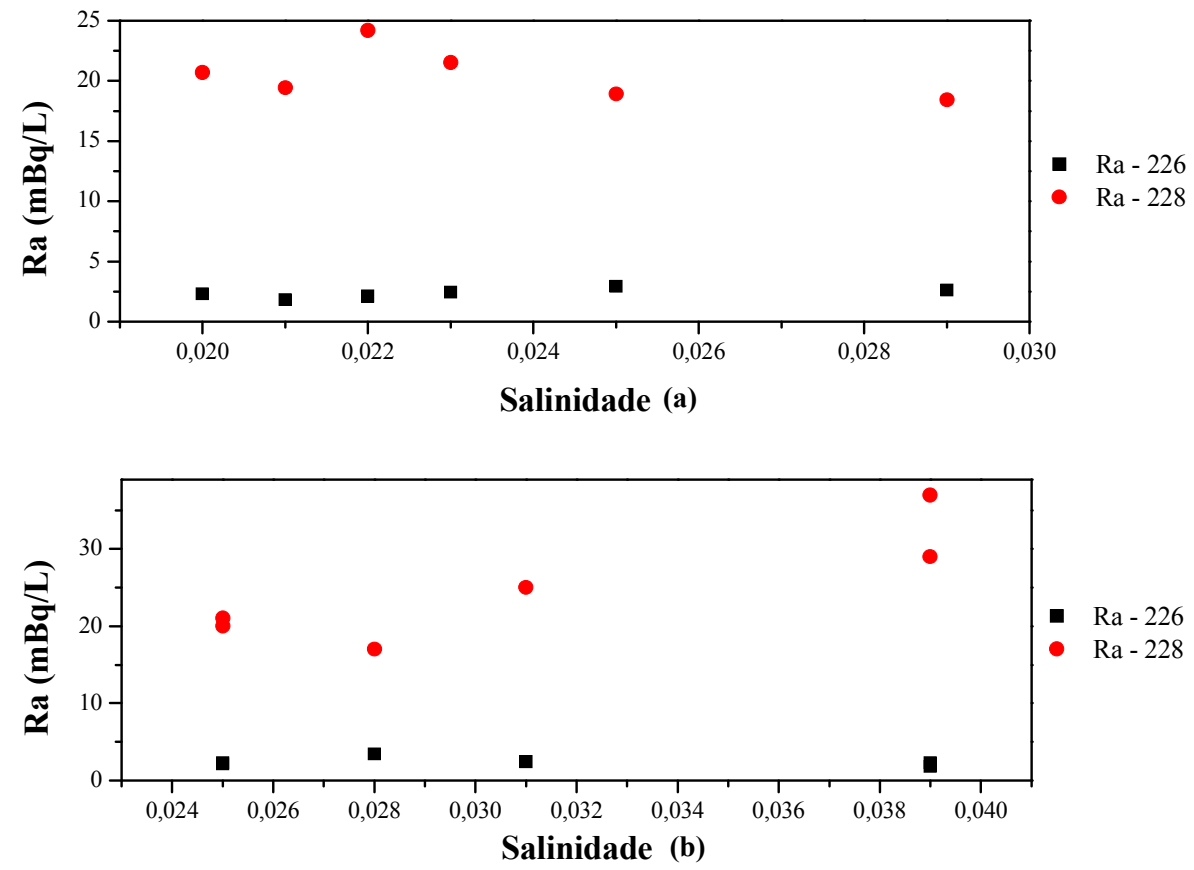

FIGURA 33 - Distribuição das concentrações de atividade dos isótopos naturais de Ra em função da salinidade nas estações hidroquímicas do Rio Ribeira de Iguape em Fevereiro/09 (a) e Agosto/09 (b). 


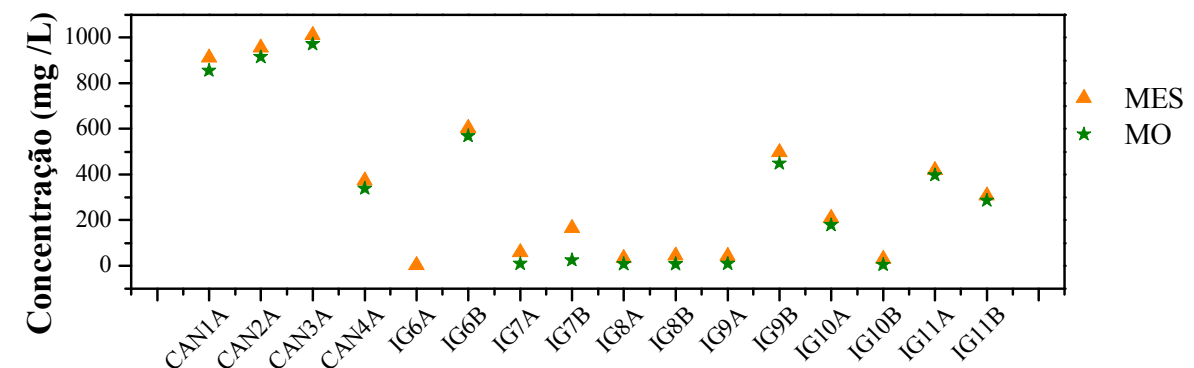

Amostras de Fevereiro/09

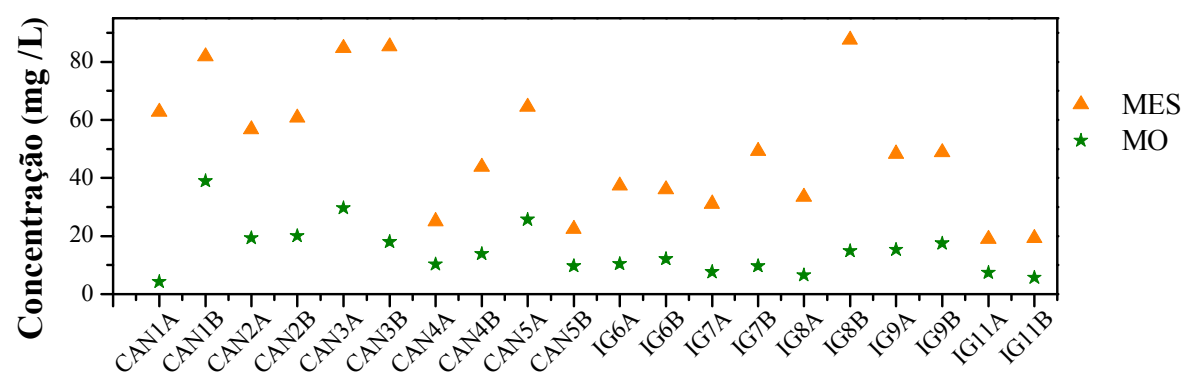

Amostras de Agosto/09

FIGURA 34 - Concentrações do material em suspensão (MES) e da matéria orgânica (MO) em suspensão nas estações hidroquímicas no sistema estuarino Cananéia e Iguape em Fevereiro/09 e Agosto/09.
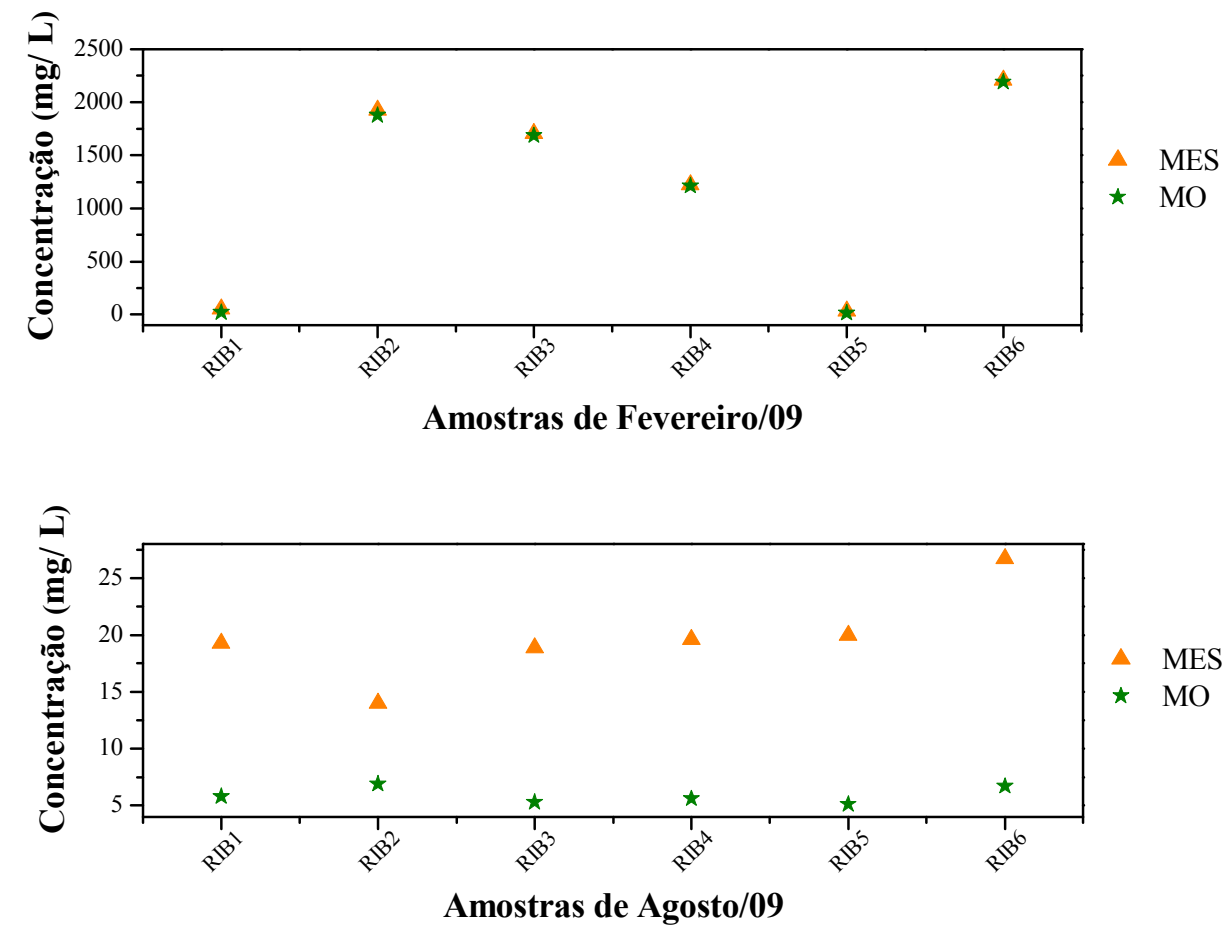

FIGURA 35 - Concentrações do material em suspensão (MES) e da matéria orgânica (MO) em suspensão nas amostras do Rio Ribeira de Iguape em Fevereiro/09 e Agosto/09. 

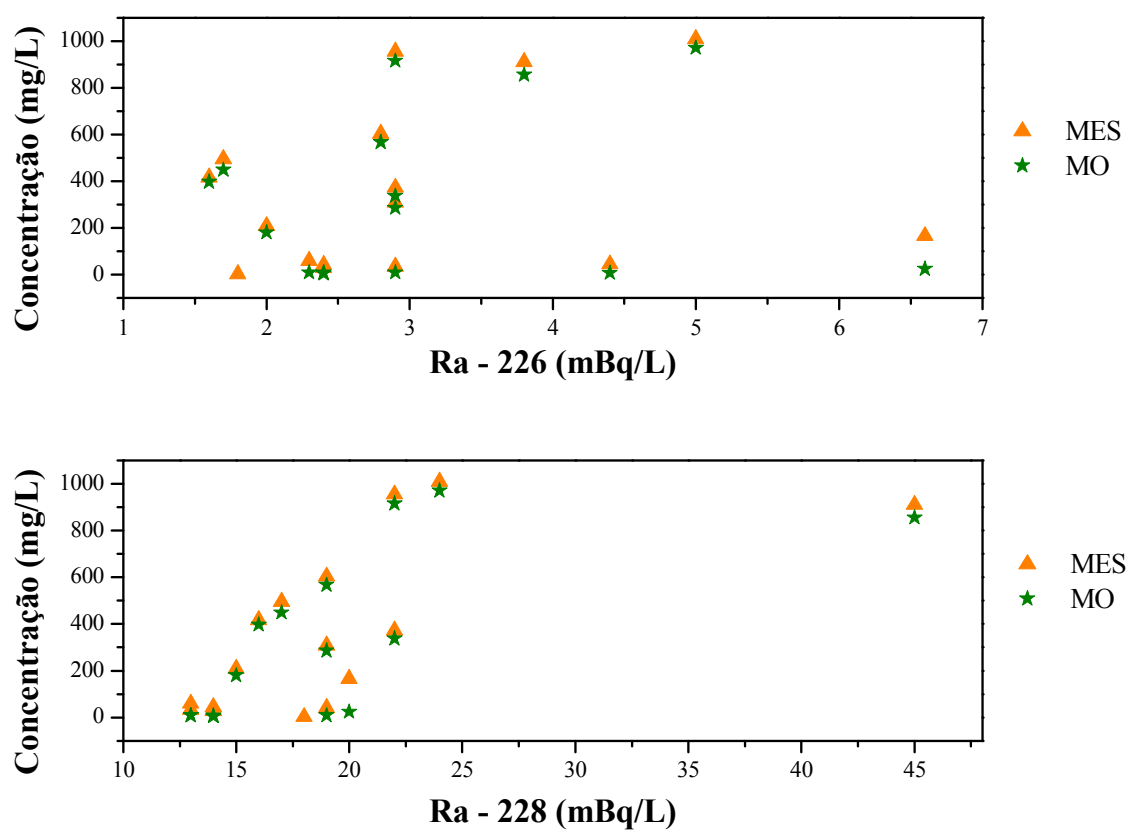

FIGURA 36 - Distribuição das concentrações de atividade dos isótopos naturais de Ra em função da concentração do material particulado em suspensão (MES) e da matéria orgânica (MO) em suspensão nas estações hidroquímicas no sistema estuarino Cananéia e Iguape em Fevereiro/09.
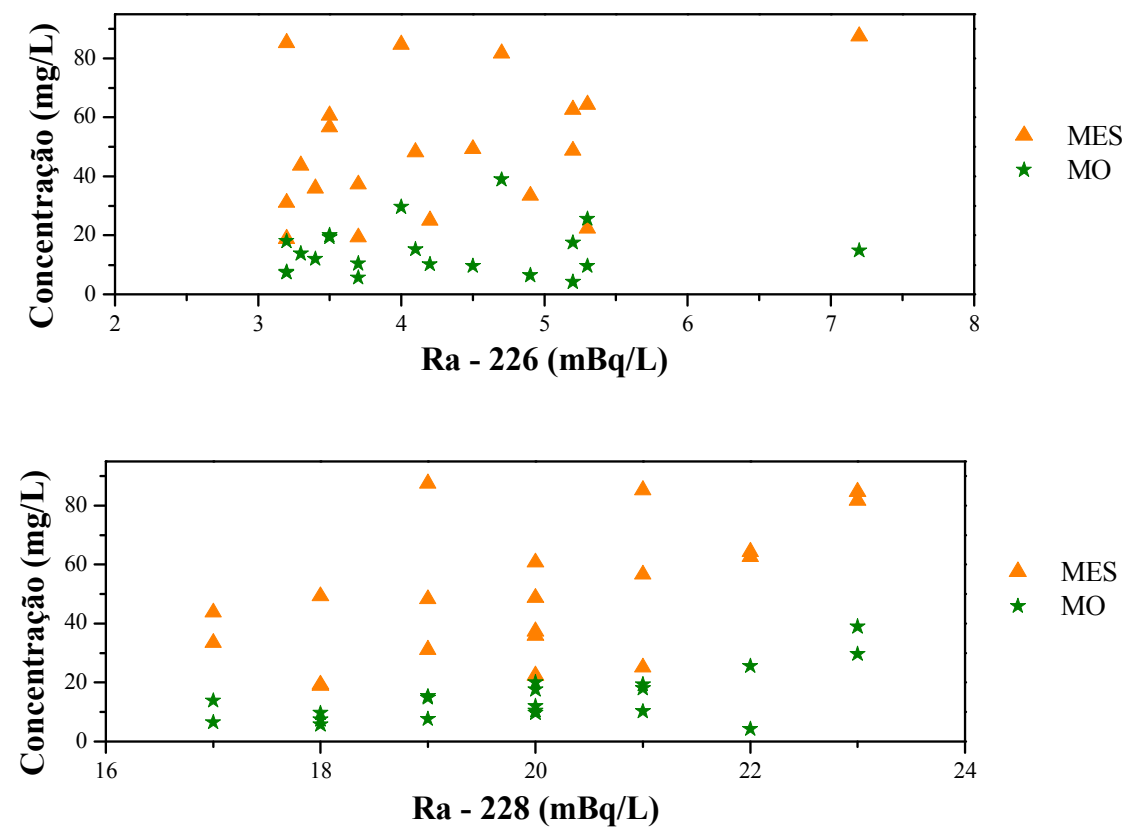

FIGURA 37 - Distribuição das concentrações de atividade dos isótopos naturais de Ra em função da concentração do material particulado em suspensão (MES) e da matéria orgânica (MO) em suspensão nas estações hidroquímicas do sistema estuarino Cananéia e Iguape em Agosto/09. 

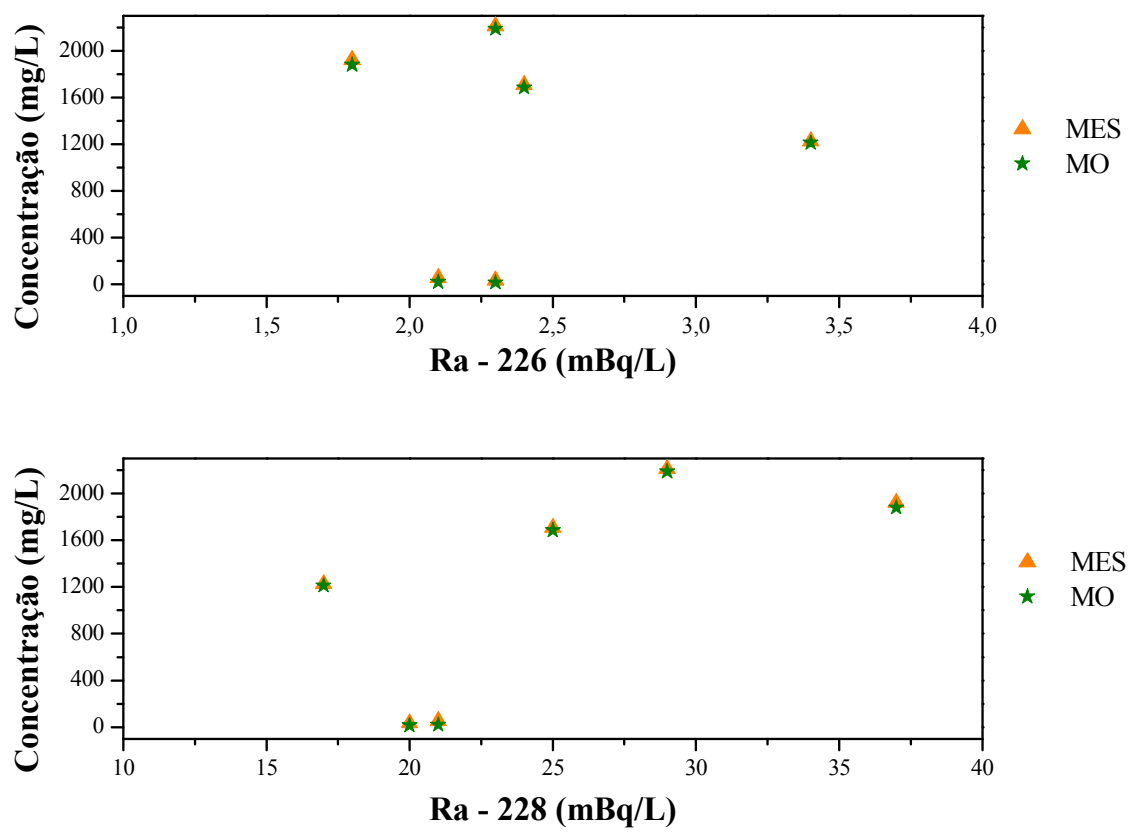

FIGURA 38 - Distribuição das concentrações de atividade dos isótopos naturais de Ra em função da concentração do material particulado em suspensão (MES) e da matéria orgânica (MO) em suspensão nas amostras do Rio Ribeira de Iguape em Fevereiro/09.
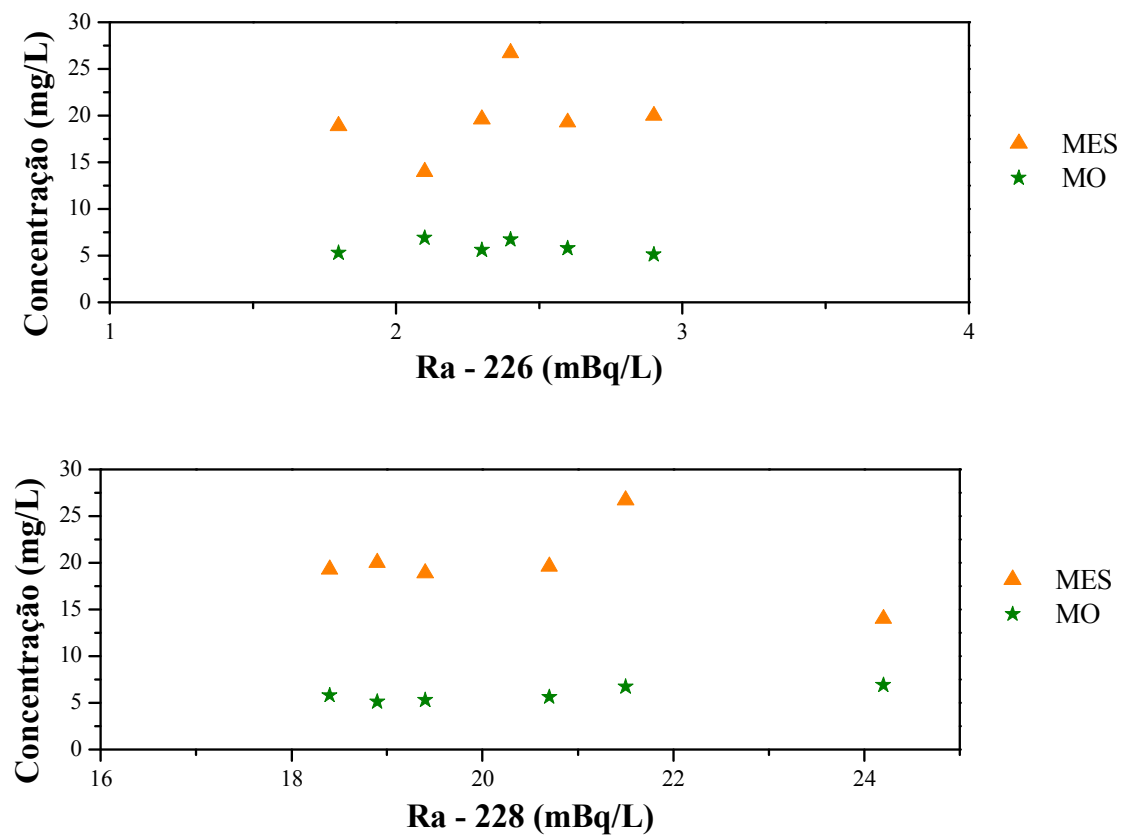

FIGURA 39 - Distribuição das concentrações de atividade dos isótopos naturais de Ra em função da concentração do material particulado em suspensão (MES) e da matéria orgânica (MO) em suspensão nas amostras do Rio Ribeira de Iguape em Agosto/09. 

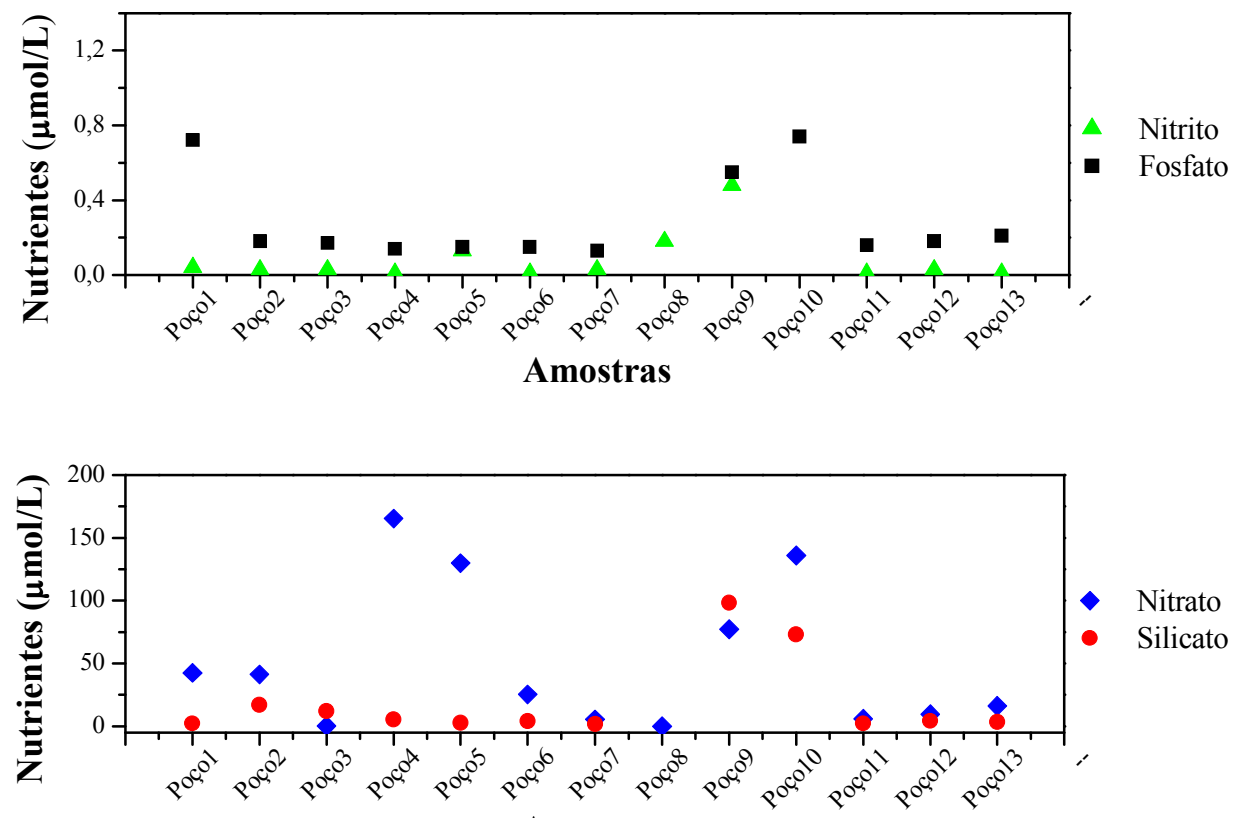

Amostras

FIGURA 40 - Distribuição das concentrações de nutrientes nas águas subterrâneas de Cananéia e Ilha Comprida em Abril/09.

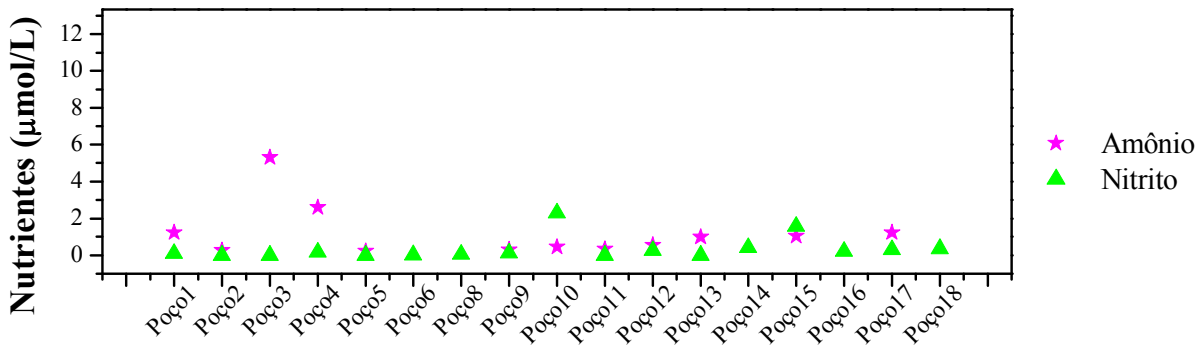

Amostras

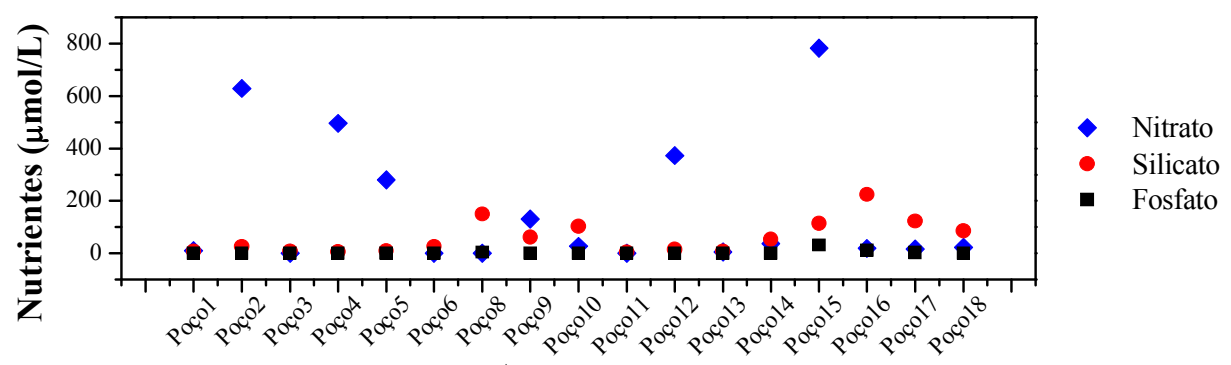

Amostras

FIGURA 41 - Distribuição das concentrações de nutrientes nas águas subterrâneas de Cananéia, Iguape e Ilha Comprida em Agosto/09. 

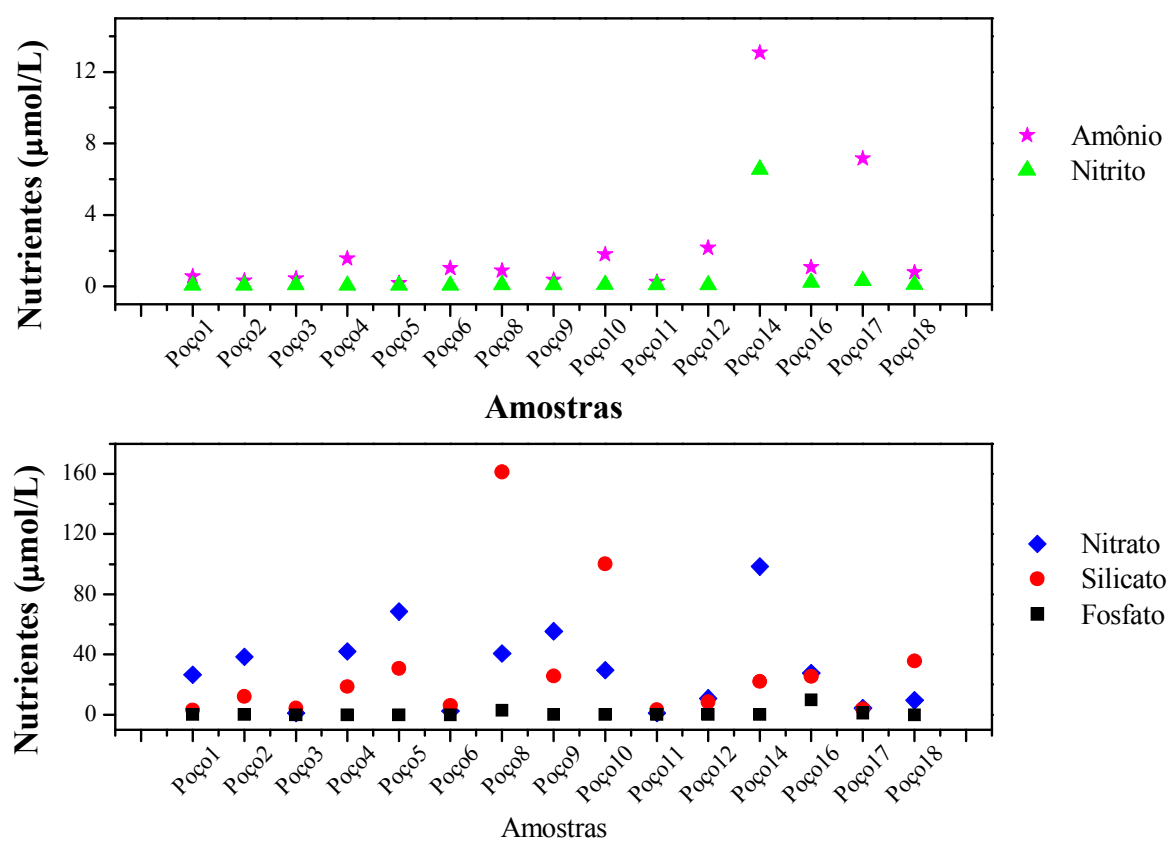

FIGURA 42 - Distribuição das concentrações de nutrientes nas águas subterrâneas de Cananéia, Iguape e Ilha Comprida em Abril/10.

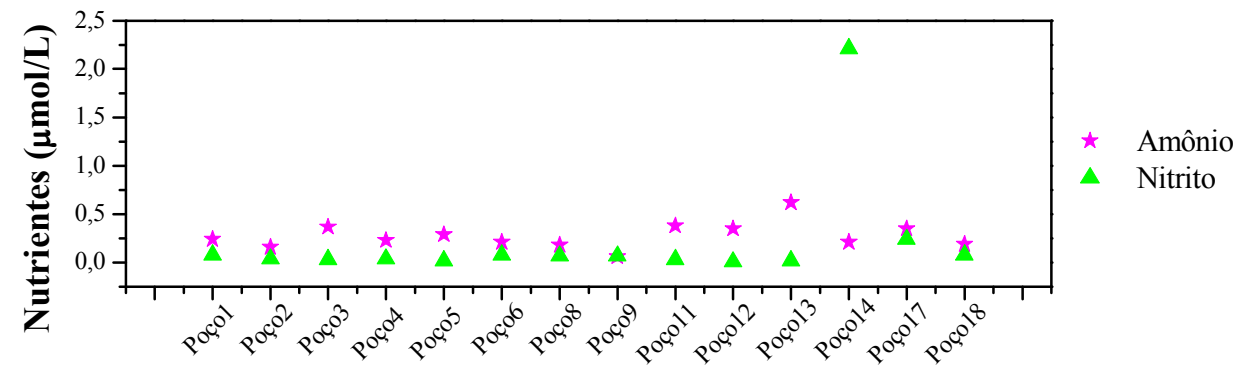

Amostras

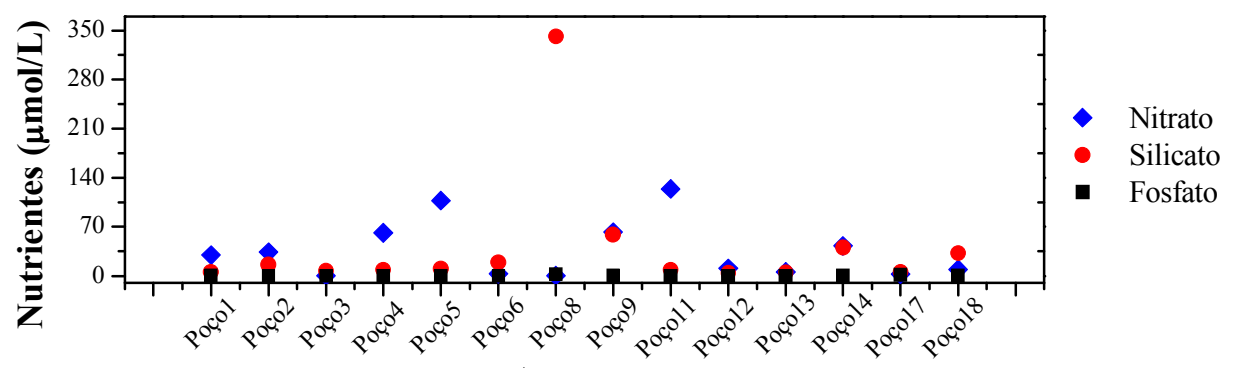

Amostras

FIGURA 43 - Distribuição das concentrações de nutrientes nas águas subterrâneas de Cananéia, Iguape e Ilha Comprida em Maio/10. 


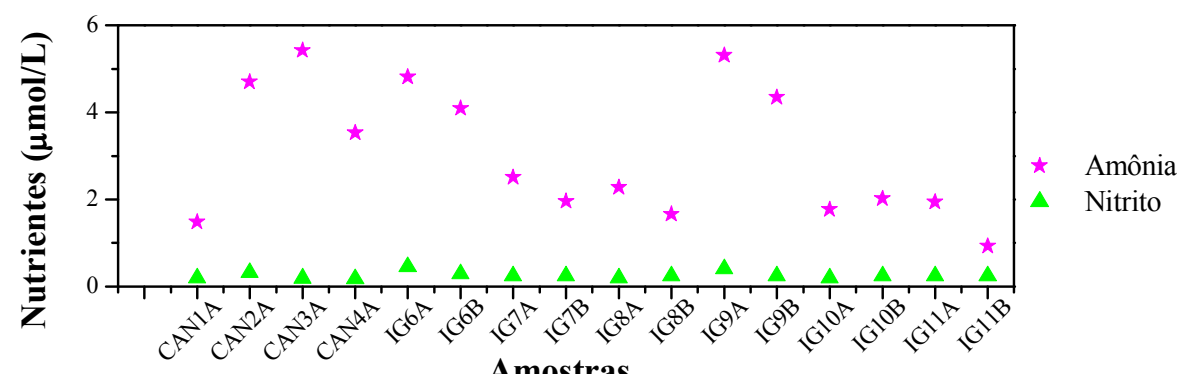

Amostras

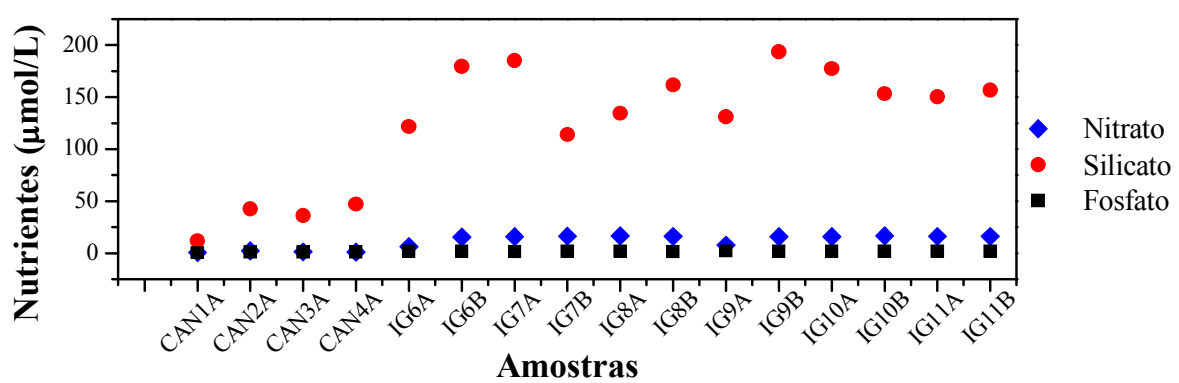

FIGURA 44 - Distribuição das concentrações de nutrientes nas estações hidroquímicas no sistema estuarino Cananéia e Iguape em Fevereiro/09.
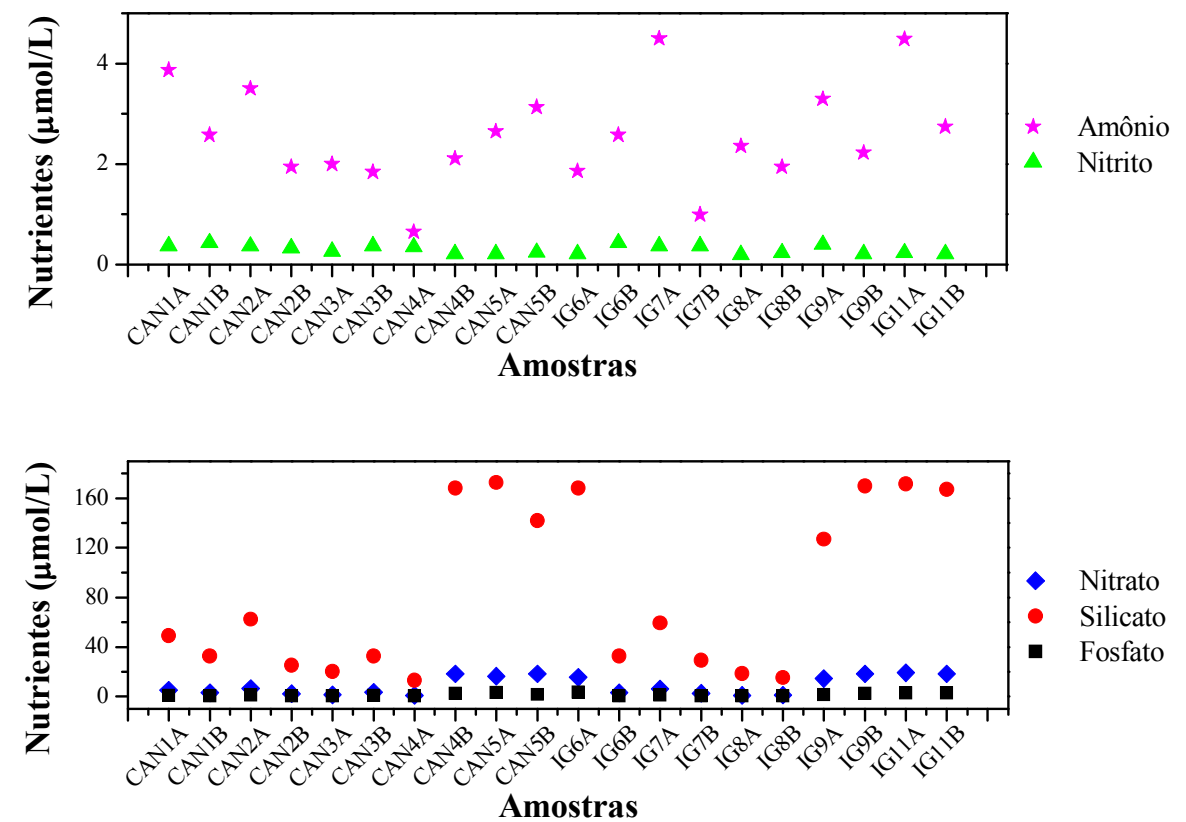

FIGURA 45 - Distribuição das concentrações de nutrientes nas estações hidroquímicas no sistema estuarino Cananéia e Iguape em Agosto/09. 

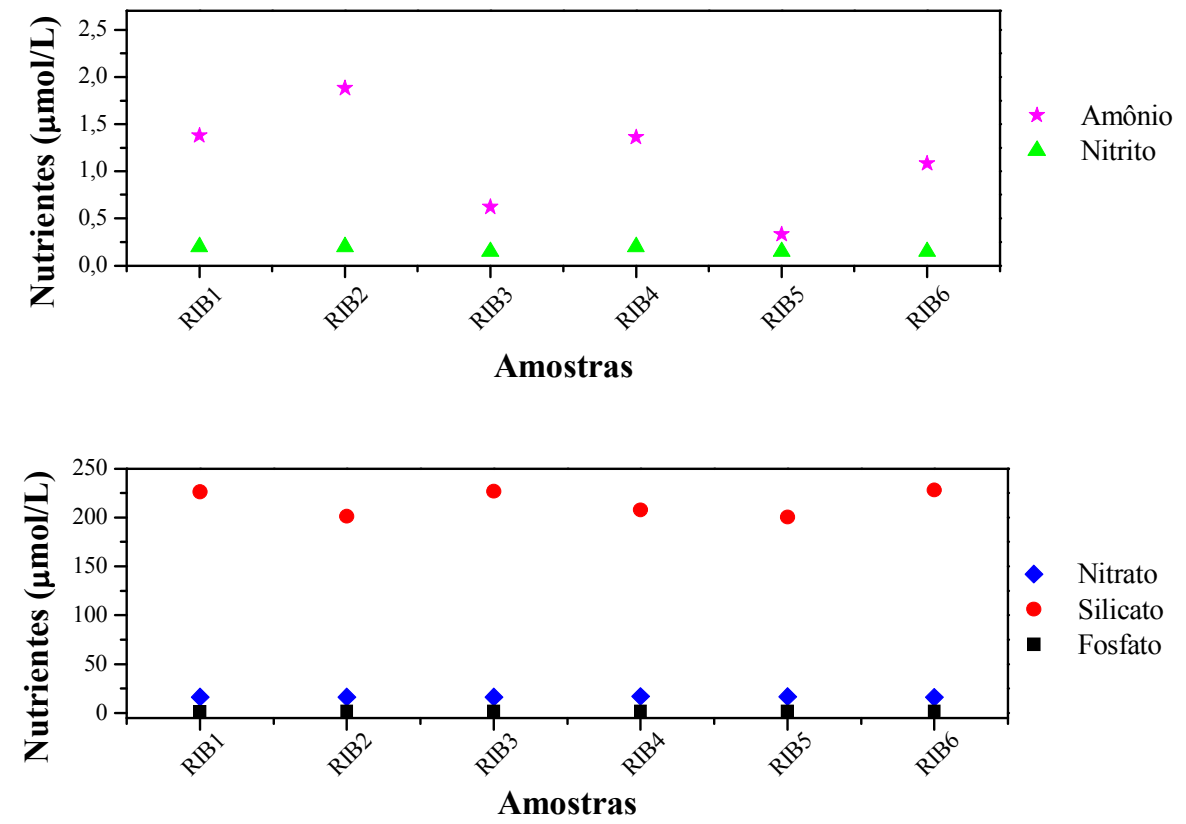

FIGURA 46 - Distribuição das concentrações de nutrientes nas estações hidroquímicas do Rio Ribeira de Iguape em Fevereiro/09.
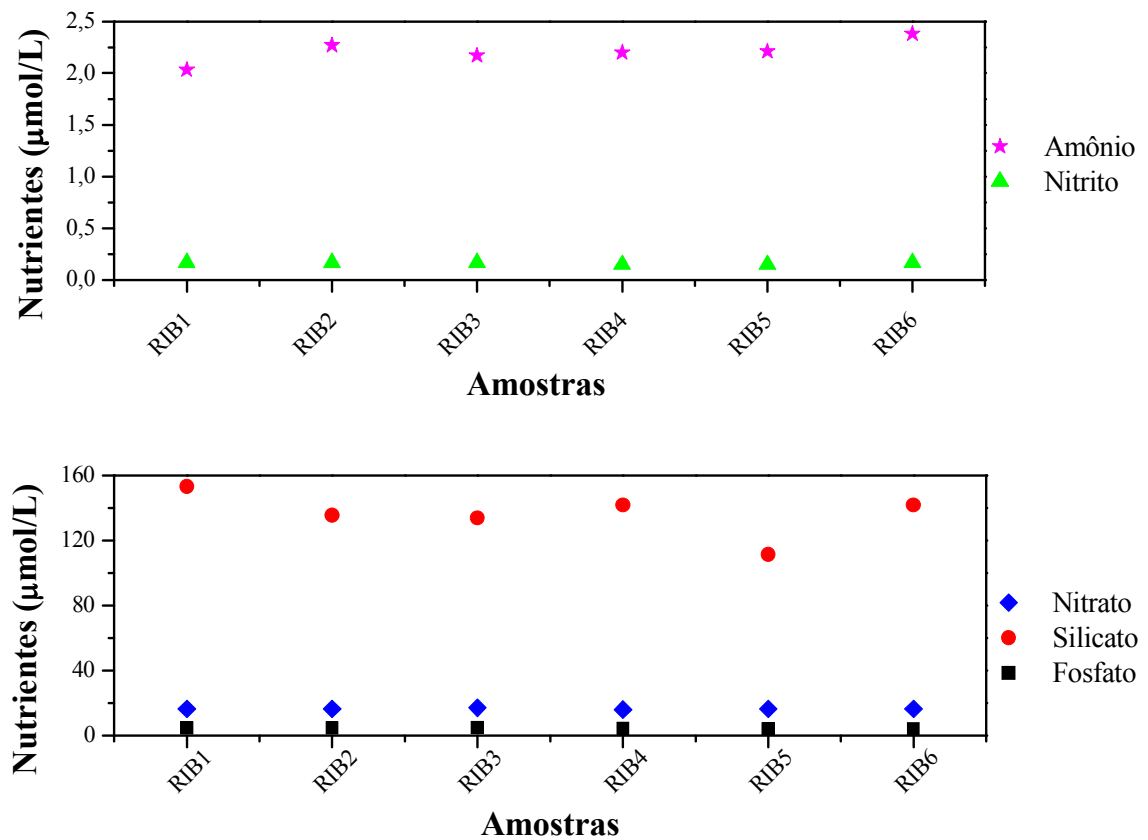

FIGURA 47 - Distribuição das concentrações de nutrientes nas estações hidroquímicas do Rio Ribeira de Iguape em Agosto/09. 


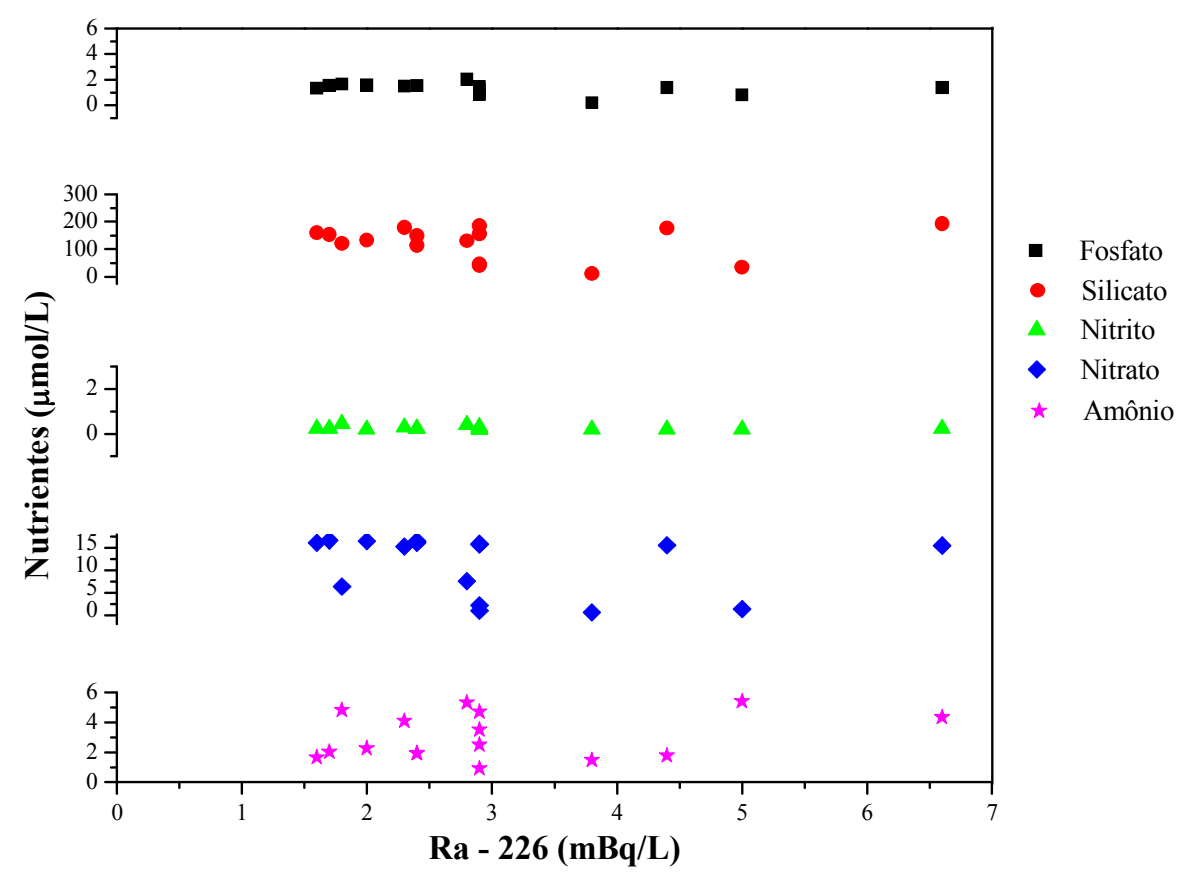

FIGURA 48 - Distribuição das concentrações de nutrientes em função da concentração do isótopo de ${ }^{226} \mathrm{Ra}$ nas estações hidroquímicas no sistema estuarino Cananéia-Iguape em Fevereiro/09.

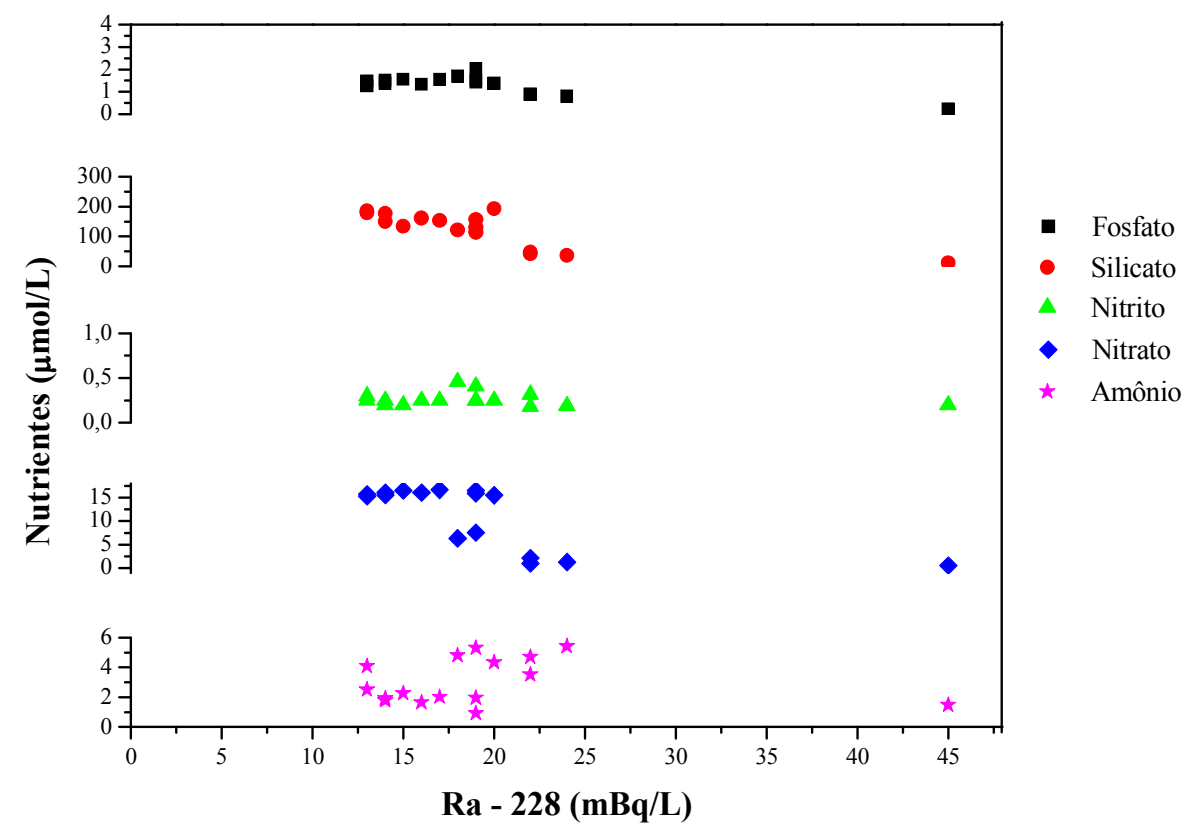

FIGURA 49 - Distribuição das concentrações de nutrientes em função da concentração do isótopo de ${ }^{228} \mathrm{Ra}$ nas estações hidroquímicas no sistema estuarino Cananéia-Iguape em Fevereiro/09. 


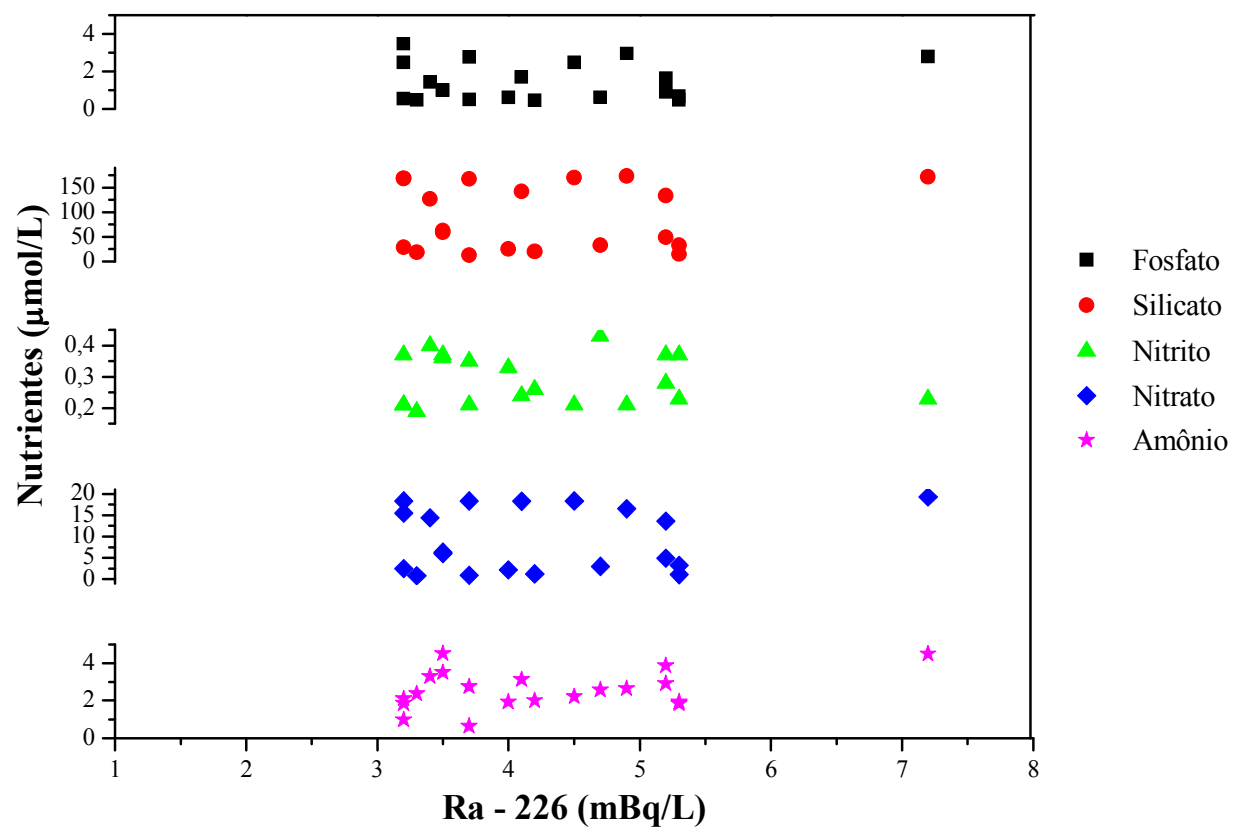

FiGURA 50 - Distribuição das concentrações de nutrientes em função da concentração do isótopo de ${ }^{226} \mathrm{Ra}$ nas estações hidroquímicas no sistema estuarino Cananéia-Iguape em Agosto/09.

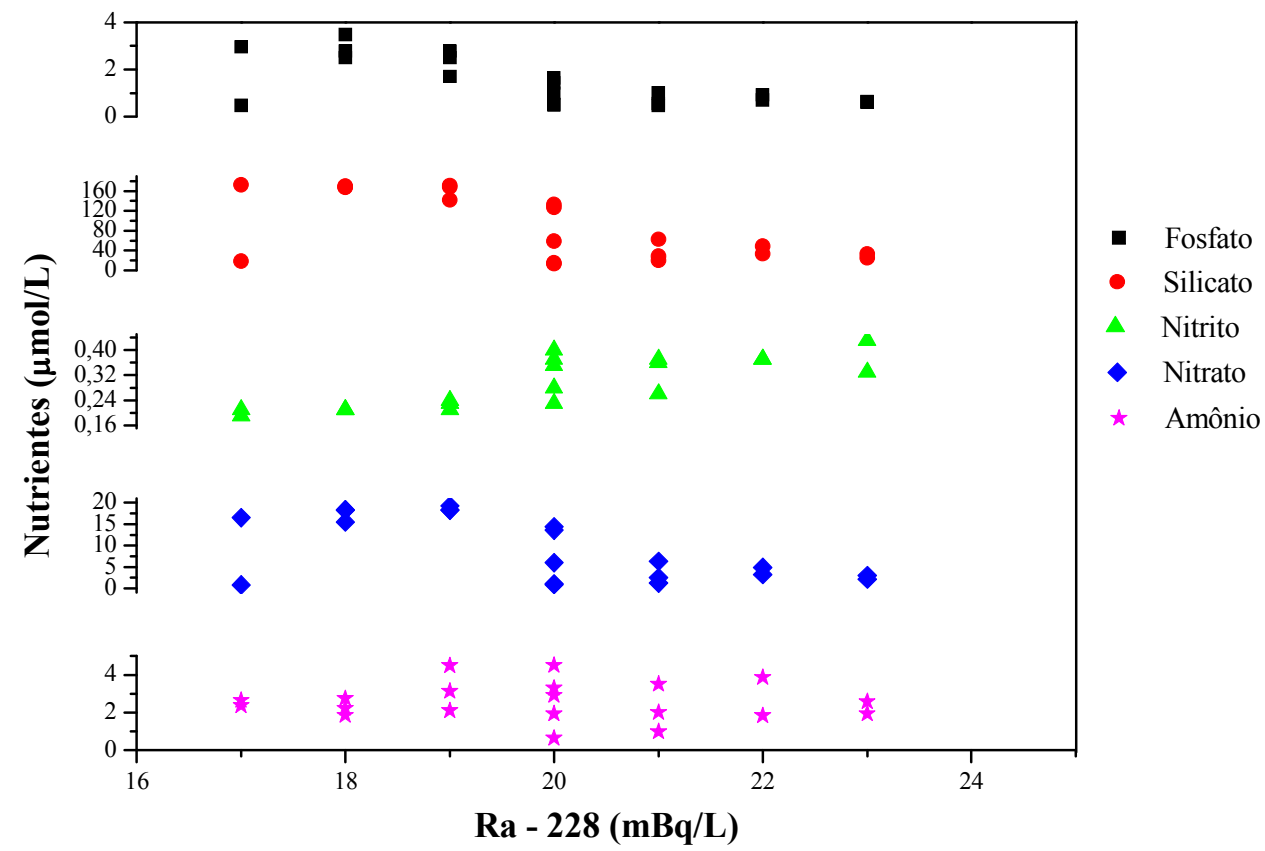

FIGURA 51 - Distribuição das concentrações de nutrientes em função da concentração do isótopo de ${ }^{228} \mathrm{Ra}$ nas estações hidroquímicas no sistema estuarino Cananéia-Iguape em Agosto/09. 


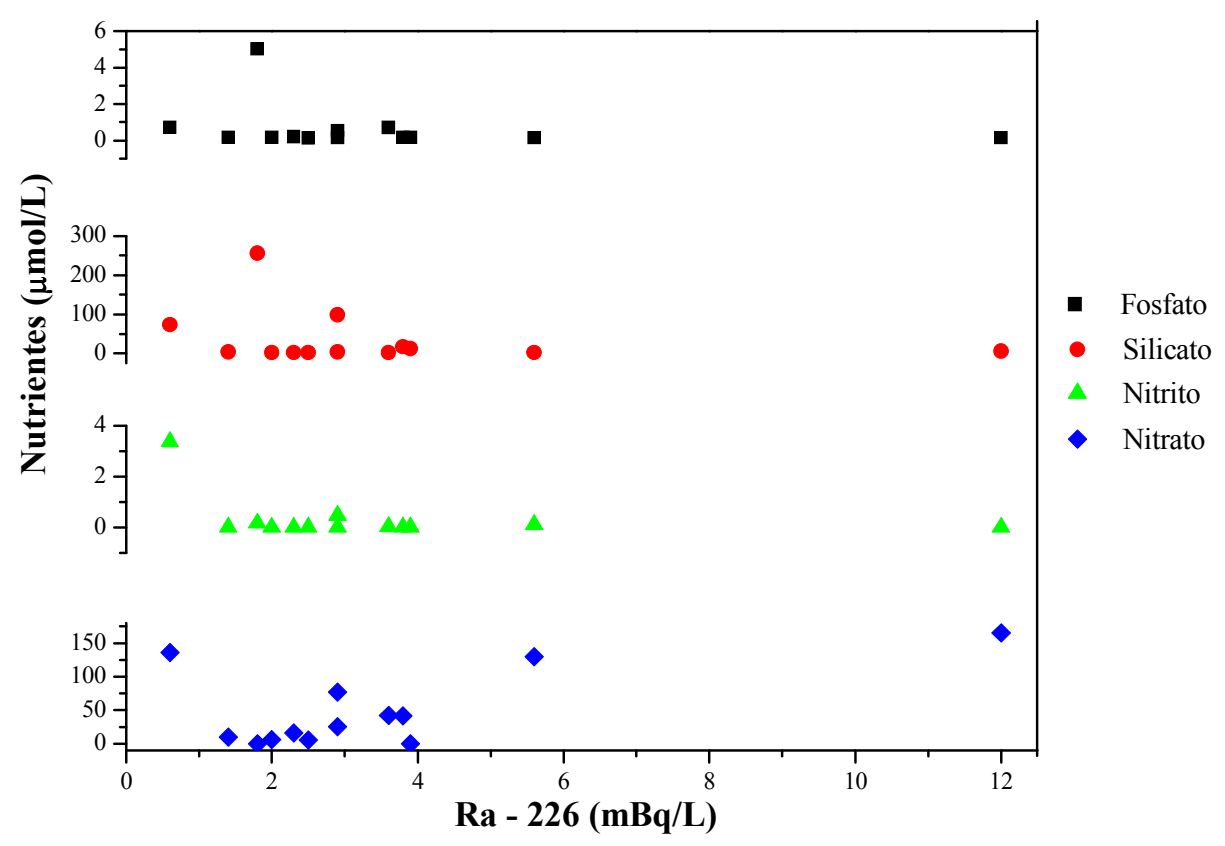

FIGURA 52 - Distribuição das concentrações de nutrientes em função da concentração do isótopo de ${ }^{226} \mathrm{Ra}$ nas águas subterrâneas de Cananéia, Iguape e Ilha Comprida Abril/09.

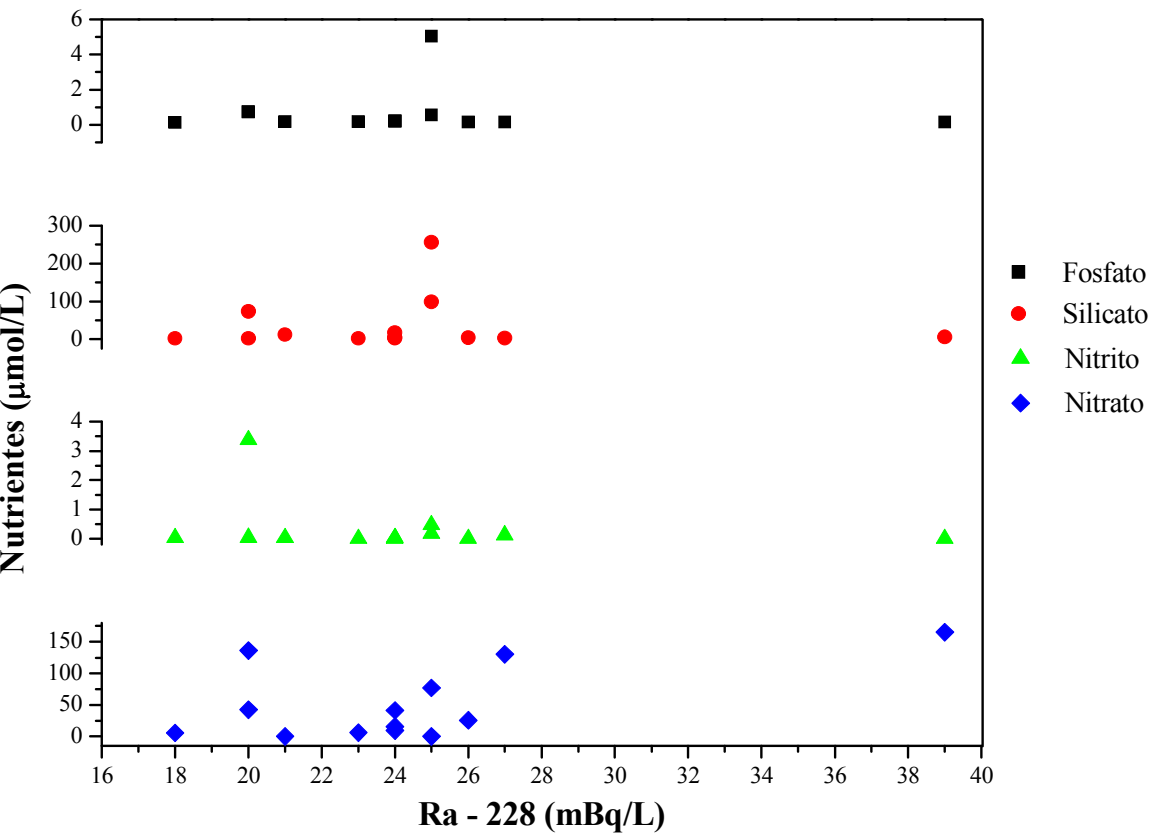

FIGURA 53 - Distribuição das concentrações de nutrientes em função da concentração do isótopo de ${ }^{228} \mathrm{Ra}$ nas águas subterrâneas de Cananéia, Iguape e Ilha Comprida Abril/09 


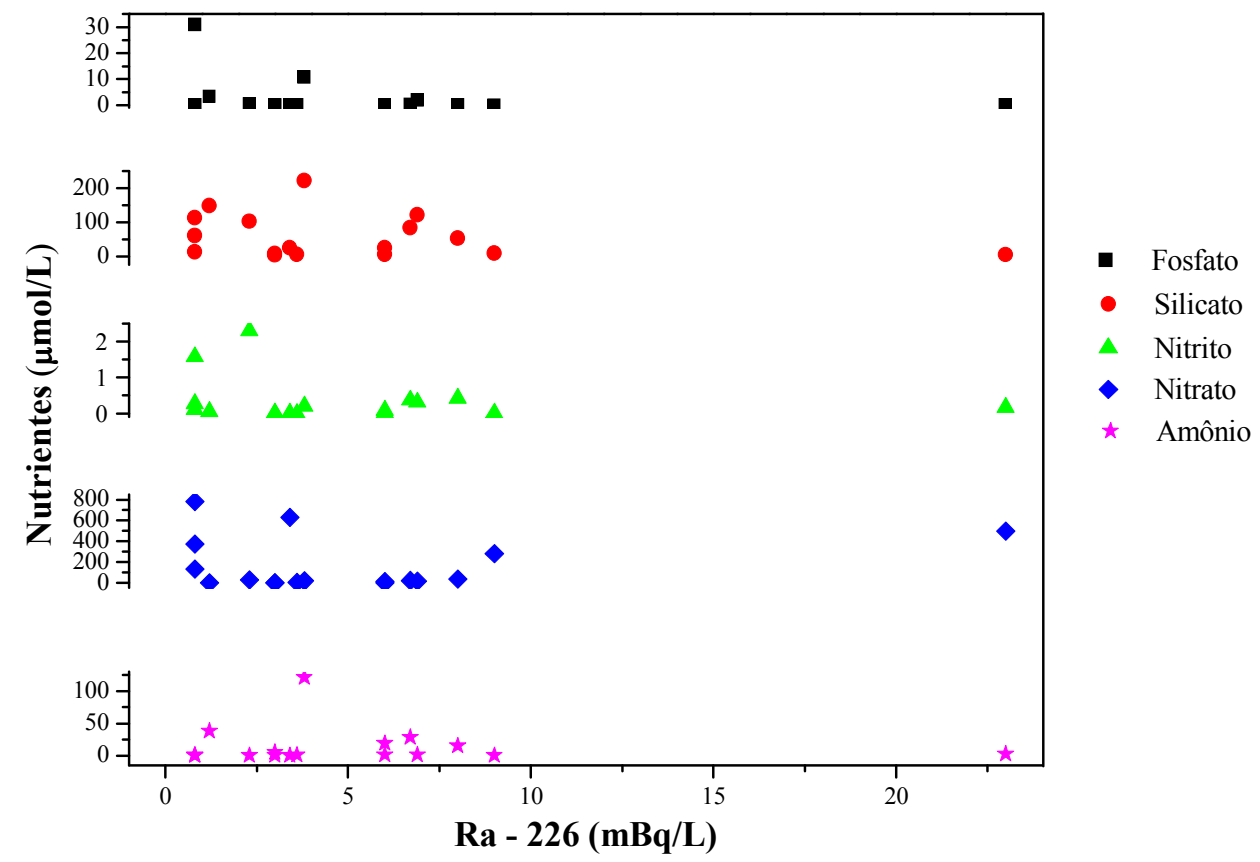

FIGURA 54 - Distribuição das concentrações de nutrientes em função da concentração do isótopo de ${ }^{226} \mathrm{Ra}$ nas águas subterrâneas de Cananéia, Iguape e Ilha Comprida Agosto/09.

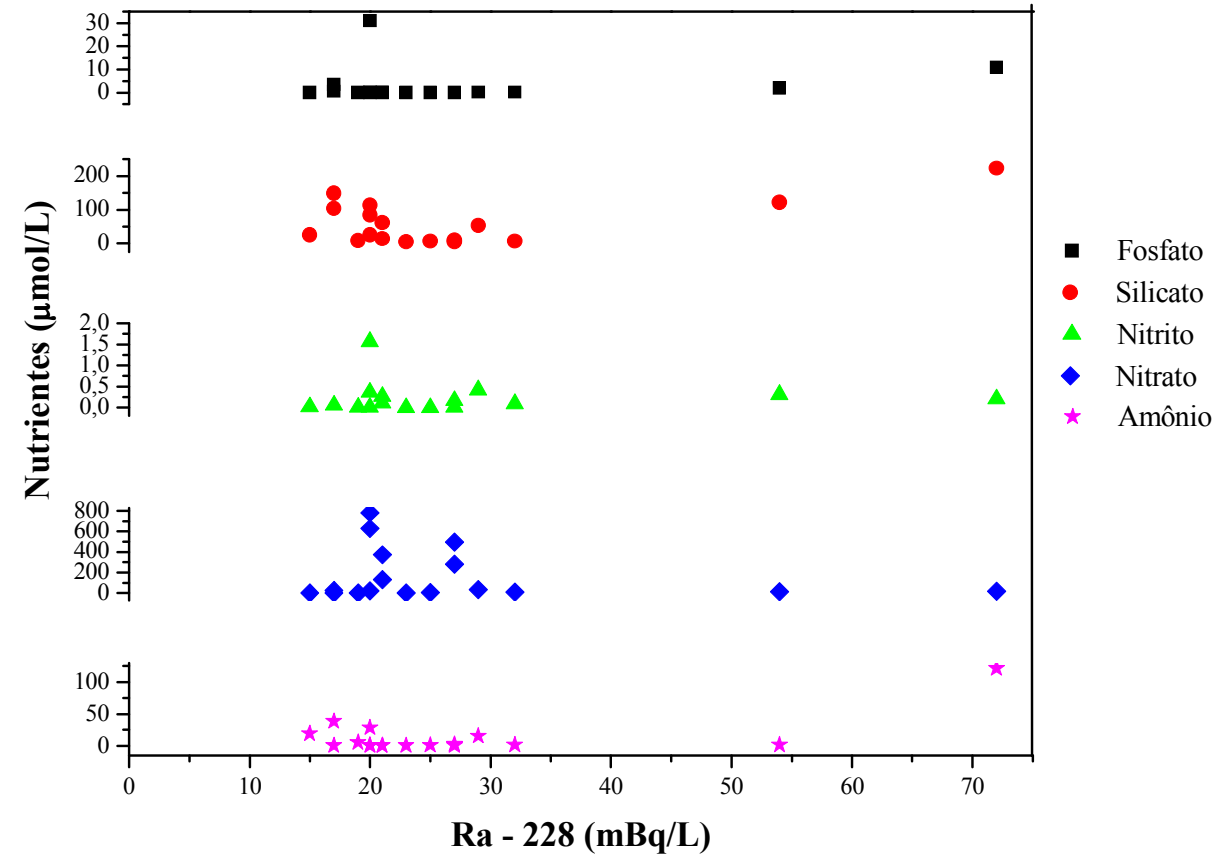

FIGURA 55 - Distribuição das concentrações de nutrientes em função da concentração do isótopo de ${ }^{228} \mathrm{Ra}$ nas águas subterrâneas de Cananéia, Iguape e Ilha Comprida em Agosto/09. 


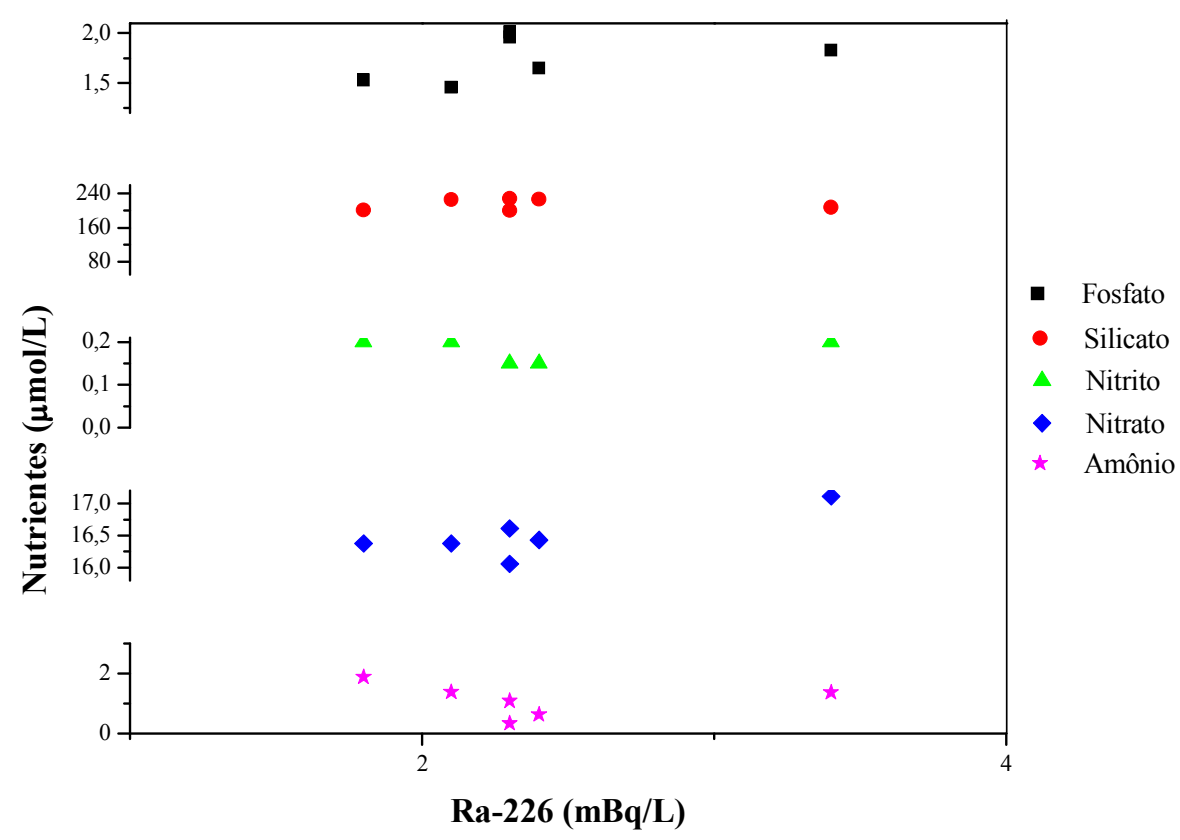

FIGURA 56 - Distribuição das concentrações de nutrientes em função da concentração do isótopo de ${ }^{226} \mathrm{Ra}$ nutrientes nas estações hidroquímicas do Rio Ribeira de Iguape em Fevereiro/09.

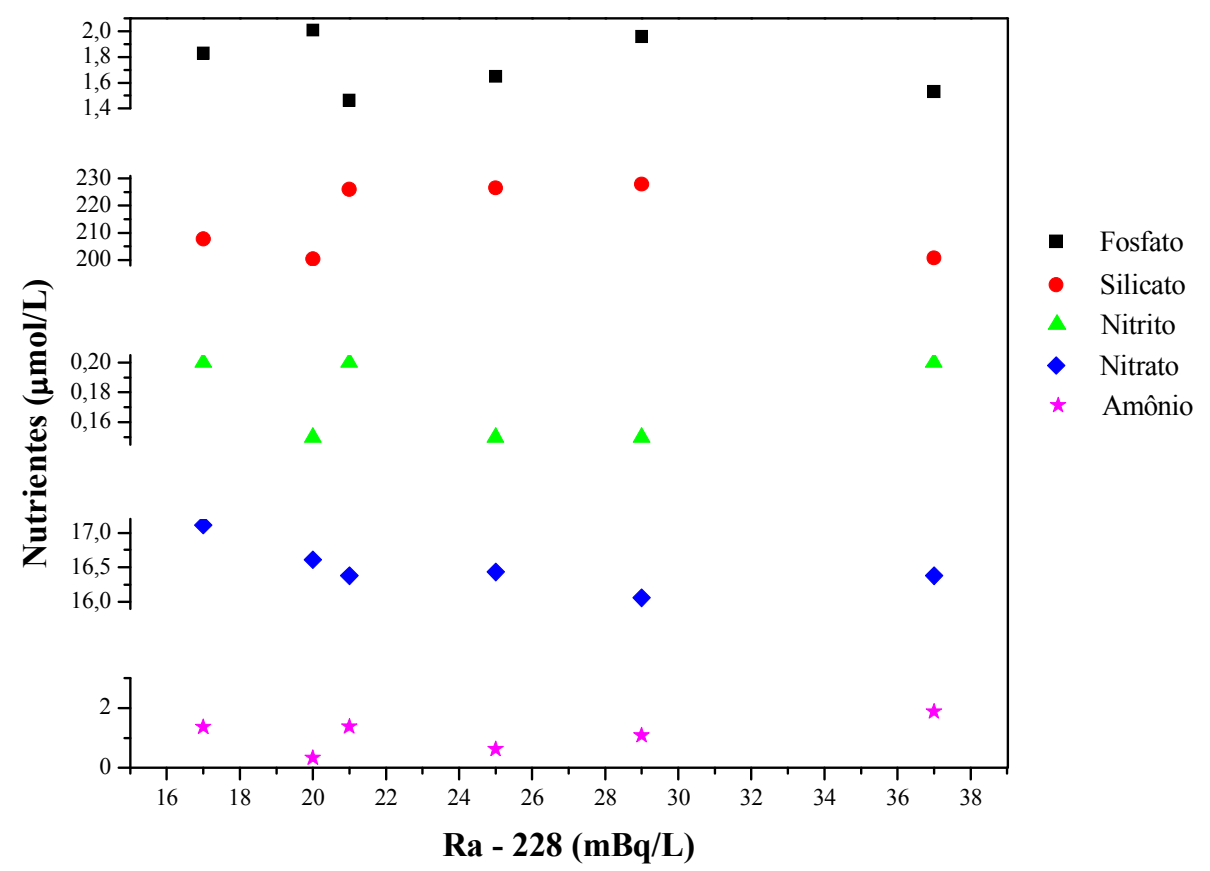

FIGURA 57 - Distribuição das concentrações de nutrientes em função da concentração do isótopo de ${ }^{228} \mathrm{Ra}$ nutrientes nas estações hidroquímicas do Rio Ribeira de Iguape em Fevereiro/09. 


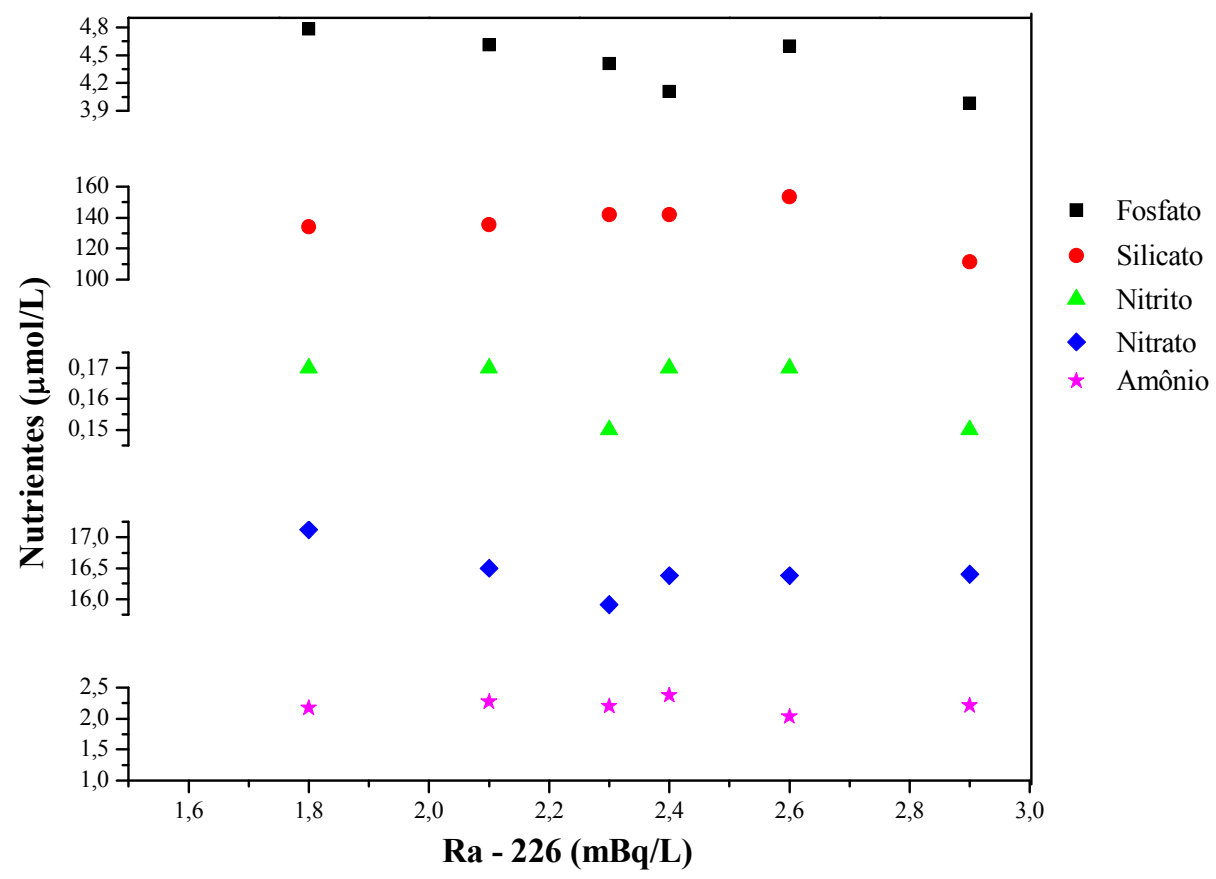

FIGURA 58 - Distribuição das concentrações de nutrientes em função da concentração do isótopo de ${ }^{226} \mathrm{Ra}$ nutrientes nas estações hidroquímicas do Rio Ribeira de Iguape em Agosto/09.

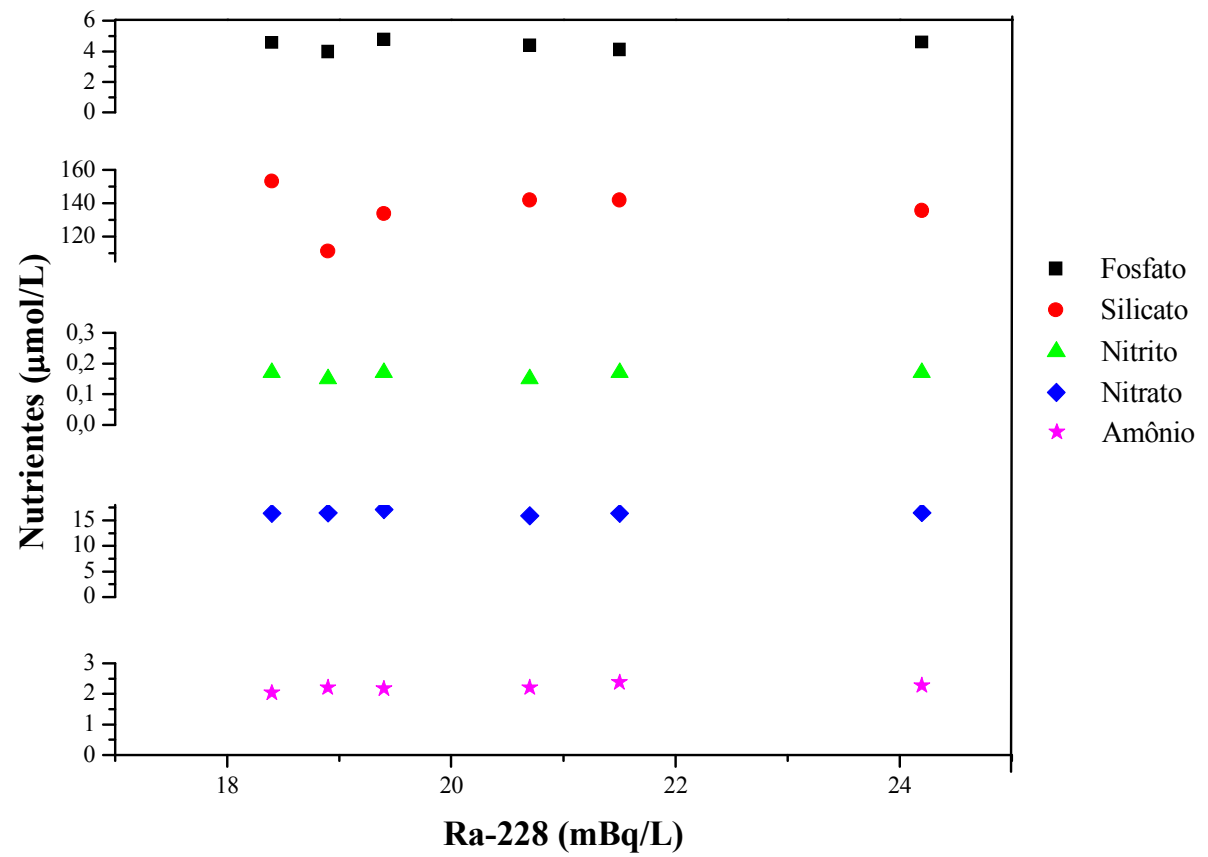

FIGURA 59 - Distribuição das concentrações de nutrientes em função da concentração do isótopo de ${ }^{228} \mathrm{Ra}$ nutrientes nas estações hidroquímicas do Rio Ribeira de Iguape em Agosto/09. 
Durante o período de investigação, em Fevereiro de 2009 (TAB. 5) foram obtidas concentrações de atividade de ${ }^{226} \mathrm{Ra}$ e ${ }^{228} \mathrm{Ra}$ nas estações hidroquímicas do sistema estuarino Cananéia-Iguape que variaram de $1,6 \mathrm{mBq} \mathrm{L}^{-1}$ a $6,6 \mathrm{mBqL}^{-1}$ e de $13 \mathrm{mBq} \mathrm{L}^{-1}$ a $45 \mathrm{mBq} \mathrm{L}{ }^{-1}$, respectivamente. Em Agosto de 2009, as concentrações de atividade de ${ }^{226} \mathrm{Ra}$ variaram de $3,2 \mathrm{mBq} \mathrm{L}^{-1}$ a 7,2 $\mathrm{mBq} \mathrm{L}^{-1}$, enquanto as de ${ }^{228} \mathrm{Ra}$ oscilaram de $17 \mathrm{mBq} \mathrm{L}^{-1}$ a $23 \mathrm{mBq} \mathrm{L}{ }^{-1}$ (TAB. 7). O maior valor de ${ }^{228} \mathrm{Ra}$ foi encontrado na Estação CAN1A, localizada próxima a Barra de Cananéia, no período de Fevereiro/09.As atividades de Ra foram ligeiramente maiores nas amostras de água coletadas aos $5 \mathrm{~m}$ de profundidade do que naquelas provenientes da superfície.

As razões de atividade ${ }^{228} \mathrm{Ra} /{ }^{226} \mathrm{Ra}$ observadas em Fevereiro de 2009 nas águas superficiais estudadas no sistema estuarino Cananéia-Iguape estiveram no intervalo de 3,0 a 11,8, o maior valor tendo sido determinado na estação hidroquímica CAN1A. Em Agosto de 2009, as razões de atividade determinadas nas mesmas estações hidroquímicas variaram de 2,6 a 6,1, com o maior valor tendo sido determinado na estação hidroquímica CAN3B, em uma profundidade de 5 metros (água de fundo).

Na campanha de Fevereiro de 2009, a variação dos valores de salinidade nas estações hidroquímicas do sistema estuarino Cananéia-Iguape foi de 0,03 a 31,60, com o maior valor registrado na estação hidroquímica CAN1A. Em Agosto de 2009, os valores de salinidade variaram de 0,65 a 32,3, com o maior valor encontrado na estação hidroquímica CAN4B, em Cananéia. Durante todo o levantamento realizado nas estações hidroquímicas, as estações que apresentaram maiores valores de salinidade localizaram-se em Cananéia. As amostras coletadas nas estações hidroquímicas estabelecidas no estuário de Iguape apresentaram menores valores de salinidade que os observados no estuário de Cananéia, evidenciando a contribuição do aporte de águas doces do Rio Ribeira de Iguape.

As concentrações de material particulado em suspensão (MES) obtidos em Fevereiro/09 nas estações hidroquímicas do sistema estuarino Cananéia-Iguape variaram de 2,4 $\mathrm{mg} \mathrm{L}^{-1}$ a $1009,4 \mathrm{mg} \mathrm{L}^{-1}$. Para a matéria orgânica (MO) os valores variaram de 4,6 $\mathrm{mg} \mathrm{L}^{-1}$ a $991,6 \mathrm{mg} \mathrm{L}^{-1}$. Os maiores valores de MES e MO foram obtidos na estação hidroquímica CAN3A. Na campanha de Agosto/09 os valores variaram de $18,9 \mathrm{mg} \mathrm{L}^{-1}$ a $87,5 \mathrm{mg} \mathrm{L}^{-1}$ para MES, o maior valor determinado na estação hidroquímica CAN3B. No caso da MO, houve uma variação de 4,2 $\mathrm{mg} \mathrm{L}^{-1}$ a $38,9 \mathrm{mg} \mathrm{L}^{-1}$, o valor mais elevado na 
estação hidroquímica CAN1B, localizado próximo a Barra de Cananéia, em uma profundidade de 5 metros (água de fundo).

As concentrações de atividade de ${ }^{226} \mathrm{Ra}$ e ${ }^{228} \mathrm{Ra}$ observadas nas estações hidroquímicas realizadas ao longo do Rio Ribeira de Iguape variaram de $2,3 \mathrm{mBq} \mathrm{L}^{-1}$ a 3,4 $\mathrm{mBq} \mathrm{L}^{-1}$ e de $17 \mathrm{mBq} \mathrm{L}^{-1}$ a $29 \mathrm{mBq} \mathrm{L}^{-1}$, respectivamente em Fevereiro de 2009 (TAB. 17). Em Agosto de 2009, as concentrações de atividade de ${ }^{226} \mathrm{Ra}$ variaram de $1,8 \mathrm{mBq} \mathrm{L}^{-1}$ a 2,9 $\mathrm{mBq} \mathrm{L}{ }^{-1}$, enquanto as de ${ }^{228} \mathrm{Ra}$ variaram de $18 \mathrm{mBq} \mathrm{L}^{-1}$ a $24 \mathrm{mBq} \mathrm{L}^{-1}$ (TAB. 19). Na FIG. 33 pode-se observar que o maior valor de atividade do ${ }^{228} \mathrm{Ra}$ foi encontrado na estação RIB2.

As razões de atividade ${ }^{228} \mathrm{Ra} /{ }^{226} \mathrm{Ra}$ nas águas superficiais das estações hidroquímicas do Rio Ribeira de Iguape estiveram no intervalo de 5,0 a 11,6, em Fevereiro/09, o maior valor tendo sido determinado na amostra RIB1, localizado próximo a barragem do Valo Grande. Em Agosto/09, essa razão variou de 6,5 a 11,5, o maior valor encontrado na estação RIB3.

Os valores do material particulado em suspensão obtidos em Fevereiro/09 nas estações hidroquímicas do Rio Ribeira de Iguape variaram de $34,0 \mathrm{mg} \mathrm{L}^{-1}$ a $2210,7 \mathrm{mg} \mathrm{L}^{-1}$. Para a matéria orgânica em suspensão os valores variaram de $14,0 \mathrm{mg} \mathrm{L}^{-1}$ a $2109,0 \mathrm{mg} \mathrm{L}^{-1}$. Os maiores valores encontrados, para os dois parâmetros estudados, foram obtidos na estação RIB6. Em Agosto/09 os valores do MES variaram de $14 \mathrm{mg} \mathrm{L}^{-1}$ a 26,7 mg L $\mathrm{mg}^{-1}$, tendo o maior valor sido determinado novamente na estação RIB6. Para valores de MO houve uma variação de $5,1 \mathrm{mg} \mathrm{L}^{-1}$ a $6,9 \mathrm{mg} \mathrm{L}^{-1}$, o valor máximo encontrado na estação RIB2.

Nas amostras de água subterrâneas coletadas nas regiões de Cananéia, Ilha Comprida e Iguape, as concentrações de atividade variaram de $0,6 \mathrm{mBq} \mathrm{L}^{-1}$ a $12 \mathrm{mBq} \mathrm{L}^{-1}$ para o ${ }^{226} \mathrm{Ra}$, e de $18 \mathrm{mBq} \mathrm{L}{ }^{-1}$ a $39 \mathrm{mBq} \mathrm{L}^{-1}$ para o ${ }^{228} \mathrm{Ra}$ em Abril/09. Na campanha de Agosto de 2009 as concentrações de atividade do ${ }^{226} \mathrm{Ra}$ e ${ }^{228} \mathrm{Ra}$ variaram de $0,8 \mathrm{mBq} \mathrm{L}^{-1}$ a $23 \mathrm{mBq} \mathrm{L} \mathrm{L}^{-1}$ e de $15 \mathrm{mBq} \mathrm{L}^{-1}$ a $72 \mathrm{mBq} \mathrm{L}^{-1}$, respectivamente. 
Nas FIG. 26 e 27, nota-se que as maiores concentrações de ${ }^{228}$ Ra nas águas subterrâneas de Cananéia ocorreram nas amostras do poços 4 e 5 , localizados no conjunto Agro Solar.

As razões de atividade ${ }^{228} \mathrm{Ra} /{ }^{226} \mathrm{Ra}$ nas águas subterrâneas das regiões de Cananéia, Ilha Comprida e Iguape, variaram 3,3 a 31,7, no período de Abril/09, o maior valor tendo sido determinado na amostro de Poço 10, situado em Ilha Comprida. Em Agosto/09, a razão de atividade variou no intervalo de 1,1 a 26,7. Em Abril e Maio de 2010, as razões de atividade estiveram no intervalo de 2,5 a 16,9 e de 2,6 a 23,6, respectivamente.

A variação da salinidade nas amostras de águas subterrâneas das regiões de Cananéia, Ilha Comprida e Iguape, coletadas em Abril/09 foi de 0,02 a 0,11, tendo se obtido o valor máximo na amostra do poço 10, em Ilha Comprida. Na Ilha Comprida, dois poços apresentaram salinidades ligeiramente acima de zero, indicando a influência da proximidade do mar, uma vez que estes se localizam a poucos metros da praia. Em Iguape, os valores de salinidade em Agosto/09 variaram de 0,02 a 0,31, o maior valor observado no poço 16. Para as amostras coletadas em Abril e Maio de 2010, os maiores valores foram encontrados nas águas do poço 6 e do poço 9, respectivamente. É importante ressaltar que a maioria dos valores obtidos de salinidade nas águas subterrâneas foram inferiores a 1 , como também visto nas amostras das estações hidroquímicas do Rio Ribeira de Iguape.

As concentrações de atividade de ${ }^{226} \mathrm{Ra}$ e ${ }^{228} \mathrm{Ra}$ nas amostras coletadas no Alto do Ribeira, em Iporanga, Núcleo Caboclos, Núcleo Bulhas D’Água, Núcleo Areado, Núcleo Ouro Grosso e Núcleo Santana, foram apresentadas nas TAB. 20 a 29. Nas águas coletadas em Abril de 2009, a concentração média aritmética de ${ }^{226} \mathrm{Ra}$ foi de $1,4 \pm 0,3 \mathrm{mBq} / \mathrm{L}$. As concentrações de ${ }^{228} \mathrm{Ra}$ variaram de 16 a $51 \mathrm{mBq} / \mathrm{L}$. As maiores concentrações de ${ }^{226} \mathrm{Ra}$, ${ }^{228} \mathrm{Ra}$ e da razão de atividade ${ }^{228} \mathrm{Ra} /{ }^{226} \mathrm{Ra}$ foram observadas nas águas da Caverna Água Suja. Esta razão de atividade ${ }^{228} \mathrm{Ra} /{ }^{226} \mathrm{Ra}$ elevada determinada na Caverna Água Suja revela que neste local há uma grande troca destes isótopos com os sedimentos, rochas do aqüífero ou com a água subterrânea drenando próximo a ela.

Nas águas de superfície coletadas no Núcleo Caboclos, em Setembro de 2009, as concentrações de ${ }^{226} \mathrm{Ra}$ variaram de 3,3 a $6,3 \mathrm{mBq} / \mathrm{L}$, enquanto que as de ${ }^{228} \mathrm{Ra}$ estiveram entre 40 e $79 \mathrm{mBq} / \mathrm{L}$. A maior concentração de ${ }^{226} \mathrm{Ra}$ foi observada no ponto Gruta do 
Chapéu Mirim. O maior valor de ${ }^{228} \mathrm{Ra}$ e da razão de atividade ${ }^{228} \mathrm{Ra} /{ }^{226} \mathrm{Ra}$ foram observados nas águas do ponto Rio do Chapéu, ao lado de uma mina de calcário.

No Núcleo Areado, as amostras foram coletadas em Outubro/2009. As concentrações de ${ }^{226} \mathrm{Ra}$ variaram de 3,2 a $6,8 \mathrm{mBq} / \mathrm{L}$, enquanto que as de ${ }^{228} \mathrm{Ra}$ estiveram entre 43 e $52 \mathrm{mBq} / \mathrm{L}$. As maiores concentrações de ${ }^{226} \mathrm{Ra}$ e de ${ }^{228} \mathrm{Ra}$ foram observadas no ponto A20. O maior valor de razão de atividade ${ }^{228} \mathrm{Ra} /{ }^{226} \mathrm{Ra}$ foi obtido nas águas do ponto A21.

As concentrações de ${ }^{226} \mathrm{Ra}$ variaram de 2,5 a $11 \mathrm{mBq} / \mathrm{L}$ nas águas estudadas no Núcleo Bulhas D'Água em Outubro de 2009, enquanto que as de ${ }^{228}$ Ra estiveram entre 40 e $45 \mathrm{mBq} / \mathrm{L}$. As maiores concentrações de ${ }^{226} \mathrm{Ra}$ e de razão de atividade ${ }^{228} \mathrm{Ra} /{ }^{226} \mathrm{Ra}$ foram obtidas no ponto A24. Durante o período de investigação, as distribuições das concentrações de atividade dos isótopos naturais de Ra ao longo dos meses nas águas de superfície evidenciaram que as maiores concentrações foram obtidas no mês de Outubro. $\mathrm{O}$ trabalho também evidenciou que nas águas dos rios o ${ }^{228} \mathrm{Ra}$ é o isótopo presente em maiores concentrações, em virtude da sua regeneração e liberação mais rápida dos sedimentos e do material particulado em suspensão, conseqüência da sua meia-vida mais curta, quando comparada a do ${ }^{226} \mathrm{Ra}$. Já no caso das águas subterrâneas, o ${ }^{228} \mathrm{Ra}$ é o isótopo que se apresenta em maiores concentrações, em conseqüência do alto teor de ${ }^{232} \mathrm{Th}$ nas rochas e sólidos dos aqüíferos da região.

Em Novembro de 2009, as concentrações de atividade de ${ }^{226} \mathrm{Ra}$ e ${ }^{228} \mathrm{Ra}$ determinadas no Núcleo Santana e no Núcleo Ouro Grosso apresentaram-se ligeiramente menores, mas as razões de atividade ${ }^{228} \mathrm{Ra} /{ }^{226} \mathrm{Ra}$ se mantiveram concordantes com a grande maioria dos outros resultados obtidos no Petar. Isto é um indicativo de provável diluição das águas estudadas em função da intensidade aumentada de chuvas. No caso da distribuição destes radionuclídeos naturais, em um dado ambiente natural, não impactado por atividades tecnológicas, em geral a distribuição das razões de atividade se mantém dentro de um intervalo conhecido, com pequenas variações.

Considerando-se os resultados das razões isotópicas em todo o conjunto de amostras desde o Alto Vale do Ribeira à planície costeira de Cananéia-Iguape, observou-se uma predominância dos isótopos naturais de Ra da série natural do ${ }^{232} \mathrm{Th}$ na maior parte 
das amostras, em comparação com os da série do ${ }^{238} \mathrm{U}$ e do ${ }^{235} \mathrm{U}$. Estes resultados refletem a presença de uma concentração maior de ${ }^{232} \mathrm{Th}$ em relação ao ${ }^{238} \mathrm{U}$ nos sedimentos e rochas cristalinas da plataforma continental do Estado de São Paulo (Pereira et al., 1986).

As concentrações de atividade de ${ }^{226} \mathrm{Ra}$ e ${ }^{228} \mathrm{Ra}$ determinadas nas águas subterrâneas e águas de superfície do Alto Vale do Ribeira e da planície costeira de Cananéia-Iguape (Abril a Outubro de 2009) são da mesma ordem de grandeza daquelas determinadas na região de Ubatuba, litoral norte do Estado de São Paulo (Burnett et al., 2008; Moore e Oliveira, 2008; de Sousa, 2008; Oliveira et al., 2009). 


\section{CAPÍTULO 7. DISCUSSÃo}

O potencial de contaminação de águas superficiais por águas subterrâneas sujeitas à infiltração de despejos e esgotos domésticos é aumentado em áreas costeiras, especialmente em corpos d'água com padrões de circulação limitada e escassez de redes de saneamento público. A importância destes fluxos derivados das águas subterrâneas e que podem vir a contaminar ou degradar a qualidade de reservatórios superficiais é dependente de vários fatores, incluindo as quantidades e eventuais enriquecimentos em nutrientes, padrões de circulação da coluna d'água e variações de maré, porosidade, permeabilidade do fundo e potencial hidráulico. Embora nosso trabalho tenha nascido da premissa de que no sistema estuarino-lagunar de Cananéia-Iguape pudessem existir interações pronunciadas entre os compartimentos subterrâneo e superficial, a distribuição das concentrações dos isótopos naturais de Ra, especialmente ${ }^{228} \mathrm{Ra}$, evidenciaram que os níveis destes isótopos neste cenário representam os níveis naturais de ocorrência (níveis naturais de fundo ou "background"). Desta forma, a distribuição dos valores de atividade de ${ }^{226} \mathrm{Ra}$ e ${ }^{228} \mathrm{Ra}$ observados nas duas regiões aonde houve o levantamento de informações a respeito da qualidade dos recursos hídricos, quanto ao critério presença de minerais de $\mathrm{U}$ e Th e radioatividade natural, demonstra que as unidades não apresentam impacto de atividades antrópicas, podendo ser classificadas como zonas primitivas, cujos resultados denotam pequena ou mínima intervenção humana.

Nos últimos anos, com a abertura definitiva da barragem do Valo Grande, o sistema estuarino-lagunar de Cananéia-Iguape sofreu mudanças ecológicas importantes, dentre as quais pode-se mencionar a diminuição dos gradientes de salinidade em Iguape até sua desembocadura no mar e a queda da reprodução de algumas espécies de algas e peixes.

A distribuição das concentrações dos isótopos ${ }^{226} \mathrm{Ra}$ e ${ }^{228} \mathrm{Ra}$ em função da salinidade na barra de Cananéia foi dominada pela sua liberação das fases particuladas em salinidades maiores que 20. Outros trabalhos de pesquisa realizados na última década no sistema de Cananéia/ Iguape demonstraram que o mesmo ocorre quanto à liberação de metais e nutrientes (Maluf, 2009; Bégamo, 2000). Os valores de salinidade determinados tanto nas amostras de água das estações hidroquímicas do Rio Ribeira de Iguape, quanto nas águas subterrâneas se apresentaram inferiores 1 durante todo o período de estudo. A 
baixa salinidade das águas dos poços amostrados indica que o processo de intrusão de água do mar no aqüífero costeiro é mínimo.

As maiores concentrações de atividade de ${ }^{226} \mathrm{Ra}$ nas águas de superfície e subterrâneas foram observadas na campanha realizada em Agosto/09. Apesar deste banco de dados ser representativo do período de inverno (seco), durante a amostragem ocorreram chuvas intensas decorrentes de instabilidade meteorológica. A incidência de chuvas aumenta o volume de água circulante nos rios e canais de maré, com conseqüente aumento na turbidez, ressuspensão de sedimentos e material particulado. Em todos os casos em que se registrou aumento do material particulado em suspensão, também se obtiveram maiores concentrações de ${ }^{228} \mathrm{Ra}$ nas águas ensaiadas.

Considerando os resultados das razões isotópicas, observou-se uma predominância dos isótopos de ${ }^{228} \mathrm{Ra}$ da série natural do ${ }^{232} \mathrm{Th}$ em todas as amostras estudadas, em comparação com os isótopos de ${ }^{223} \mathrm{Ra},{ }^{224} \mathrm{Ra}$ e ${ }^{226} \mathrm{Ra}$. Estes resultados refletem a presença de uma concentração maior de ${ }^{232} \mathrm{Th}$ em relação ao ${ }^{238} \mathrm{U}$ nas rochas e sólidos dos aqüífero na região de interesse (Pereira et al., 1986).

A razão de atividade ${ }^{228} \mathrm{Ra} /{ }^{226} \mathrm{Ra}$ aumentada determinada na estação hidroquímica CAN1A, localizada próximo a Barra de Cananéia, é conseqüência da alta força-iônica neste local (salinidade 31,6). Segundo o estudo realizado por Bégamo (2000), o perfil médio de salinidade obtido na Barra de Cananéia, apresentou a haloclina relativamente intensa. O perfil médio de velocidade mostrou movimentos unidirecionais, típicos de estuário bem misturado, indicando que a circulação foi totalmente forçada pela maré.

$\mathrm{O}$ valor da razão de atividade ${ }^{228} \mathrm{Ra} /{ }^{226} \mathrm{Ra}$ elevada na estação RIB2, indica que neste local há uma grande troca destes isótopos com o sedimentos ou o material em suspensão. Nesta posição pode existir turbulência ou possível nascente, uma vez que o baixo valor de salinidade demonstra que a força-iônica não foi o processo dominante de liberação do Ra do material particulado em suspensão.

As maiores razões de atividade ${ }^{228} \mathrm{Ra} /{ }^{226} \mathrm{Ra}$ nas águas subterrâneas foram obtidas em Ilha Comprida. O poço 10 que apresentou maior valor de razão de atividade, se localiza às margens da praia de Ilha Comprida, indicando que na linha de costa há processos 
intensos de troca dos isótopos de $\mathrm{Ra}$ com os sedimentos inconsolidados e as águas em contato com os mesmos.

A maior concentração de atividade de ${ }^{228} \mathrm{Ra}$ nas águas doces foi observada no Núcleo Cablocos, situado no Parque Estadual Turístico do Alto Ribeira (PETAR). Neste local foram notadas rotas de fluxo de águas subterrâneas com alto gradiente hidráulico e freqüentemente associadas a sistemas de cavernas com entalhamentos fluviais subterrâneos que atingem até $60 \mathrm{~m}$ (Ferrari, 1998). O maior valor da razão de atividade presente nas amostras do Alto Vale do Ribeira, foi obtido na amostra A2, proveniente da Caverna Água Suja, uma região localizada no bloco tectônico do Lajeado, ocupado pela seqüência metassedimentar de baixo grau metamórfico, composta por unidades pelíticas, psamíticas e carbonáticas (Karmann \& Ferrari, 2002).

Os nutrientes que apresentaram concentrações significativas tanto nas estações hidroquímicas, quanto nas águas subterrâneas foram o silicato e o nitrato, sendo os valores encontrados de $255,5 \mu \mathrm{mol} \mathrm{L}^{-1}$ e $782,4 \mu \mathrm{mol} \mathrm{L}^{-1}$, respectivamente. Segundo alguns autores (Moore \& Shaw, 1998), existe uma forte correlação entre as concentrações de silicato e Ra na água subterrânea e água salinizada.

A distribuição das concentrações de atividade dos isótopos naturais Ra em função do material particulado em suspensão (MES) e da matéria orgânica (MO), evidenciam que na campanha de Fevereiro/09 os dois índices apresentaram concentrações equivalentes. As distribuições destes valores em função da distribuição das concentrações de atividade dos isótopos naturais de ${ }^{226} \mathrm{Ra} \mathrm{e}{ }^{228} \mathrm{Ra}$ também foram similares.

Nas amostras coletadas ao longo do Rio Ribeira de Iguape e nos estuários de Cananéia e de Iguape, as maiores concentrações dos isótopos de Ra foram observadas nas águas de fundo, indicando a difusão do ${ }^{228} \mathrm{Ra}$ dos sedimentos recentemente depositados como uma fonte potencial das concentrações aumentadas deste isótopo em relação aos demais. As concentrações dos isótopos de meias-vidas curtas foram negligenciáveis, em sua maior parte menores que o limite inferior de detecção do método.

Os fluxos de Ra para o sistema na Barra de Cananéia são fortemente influenciados pelas correntes e canais de maré, que modulam o aumento ou diminuição das 
concentrações de Ra em resposta direta ao respectivo aumento e diminuição da salinidade das águas. No estuário de Iguape e nas estações hidroquímicas realizadas no Rio Ribeira do Iguape observou-se uma correlação linear entre a quantidade de material em suspensão (MES) e o aumento da concentração de ${ }^{228} \mathrm{Ra}$.

Quando se avaliam qualitativamente as diferenças entre o comportamento dos dois isótopos de $\mathrm{Ra}$ de meias-vidas longas, as concentrações de ${ }^{226} \mathrm{Ra}$ não apresentaram distribuição idêntica aquelas do ${ }^{228} \mathrm{Ra}$. Isto demonstra um aporte negligenciável advectivo das águas intersticiais dos sedimentos e subterrâneas para o cenário de interesse. Os fluxos dominantes de elementos-traço, radionuclídeos e nutrientes tem suas maiores fontes centradas no compartimento fluvial, sedimentos e material em suspensão.

As concentrações de atividade de ${ }^{226} \mathrm{Ra}$ e ${ }^{228} \mathrm{Ra}$ determinadas nas águas subterrâneas e águas de superfície do Alto Vale do Ribeira e da Planície Costeira do Litoral Sul do Estado de São Paulo (2009 - 2010) são da mesma ordem de grandeza daquelas determinadas no Litoral Norte (Burnett et al., 2008; Moore \& Oliveira, 2008; Sousa, 2008).

A partir dos valores máximos das concentrações de atividade de ${ }^{226} \mathrm{Ra}$ e de ${ }^{228} \mathrm{Ra}$ determinadas, as doses efetivas comprometidas potenciais recebidas pelos indivíduos do público que consomem estas águas foram estimadas. A determinação deste parâmetro é inédita para a região e tem por finalidades avaliar o atendimento à Portaria 518 do Ministério da Saúde (2004) que estabelece os limites de qualidade da água destinada ao consumo humano no Brasil. Estes cálculos consideraram a hipótese de consumo diário de 2 L de água ao longo de um ano (Oliveira et al., 2001). Os valores dos fatores de conversão de dose efetiva comprometida para o ${ }^{226} \mathrm{Ra}$ e o ${ }^{228} \mathrm{Ra}$ são respectivamente: $2,8 \times 10^{-7} \mathrm{~Sv} / \mathrm{Bq}$ e $6,6 \times 10^{-7} \mathrm{~Sv} / \mathrm{Bq}$ (ICRP 67, 1993). Os resultados obtidos demonstram que as doses calculadas não excederam nível de referência de dose efetiva comprometida recomendado de 0,1 mSv, considerando-se o consumo de água potável por um ano (WHO, 2003). As doses efetivas comprometidas estimadas devido à ingestão de ${ }^{226} \mathrm{Ra}$ e ${ }^{228} \mathrm{Ra}$ são várias ordens de grandeza inferiores ao limite de dose de $0,1 \mathrm{mSv}$. Também foi avaliado se o limite secundário foi ultrapassado, considerando-se o consumo diário de $2 \mathrm{~L}$ por pessoa (WHO, 2003) e a concentração correspondente de ${ }^{226} \mathrm{Ra}$ obtida. O respectivo valor do limite de incorporação anual utilizado neste cálculo foi de $7 \times 10^{4}$ Bq para o ${ }^{226} \operatorname{Ra}(\mathrm{CNEN}$ 
NN 3.01, 2005). O valor obtido no cálculo foi de 0,0057 ,e portanto, o limite secundário foi menor que a unidade.

A partir destes dados, concluiu-se que os limites secundários não foram superados e, portanto, quanto aos padrões de qualidade radioativa, as águas subterrâneas e de superfície do Vale do Ribeira e da Planície Costeira de Cananéia-Iguape podem ser consumidas sem que isto ocasione algum dano adicional à saúde da população. 


\section{CAPÍTULO 8. CONCLUSÕES}

Os rios transportam produtos do intemperismo continental e fornecem aos oceanos diversos compostos químicos. A "assinatura" da contribuição dos processos erosivos para os fluxos de materiais no oceano é moderada pelos ciclos biogeoquímicos que ocorrem nos estuários. Embora o sistema estuarino de Cananéia-Iguape não apresente as características de um estuário clássico (Bérgamo, 2000), a porção sul do mar de Cananéia pode ser enquadrada nesta definição de sistema, com condições controladas das forçantes descarga de águas doces, ventos e gradientes de pressão. O estuário de Cananéia é um canal raso e até recentemente, antes do rompimento da barragem do Valo Grande, do tipo parcialmente misturado e fracamente estratificado (Miyao \& Harari, 1989). O trabalho de Bérgamo (2010) descreveu o balanço de sal e a contribuição de cada uma das suas componentes, advectivas e dispersivas, durante maré de sizígia em condições de verão, demonstrando que o transporte não estava em balanço, com a descarga de água doce dominando o transporte advectivo, e o transporte dispersivo pela propagação da onda de maré no canal estuarino. Pela comparação do perfil estacionário de velocidade com os resultados de um modelo analítico uni-dimensional de um estuário ideal verticalmente homogêneo, concluiu que as principais forças geradoras de movimento no sistema foram o gradiente longitudinal de densidade e a descarga de água doce. Na pesquisa de Bérgamo (2000), a estação da Barra de Cananéia apresentou os maiores valores médios de salinidade e correntes mais intensas, sendo o oposto para a Baía do Trapandé, sugerindo que as trocas entre águas oriundas da drenagem continental e da região costeira adjacente são mais efetivas pelo canal do Mar de Cananéia. O transporte de sal foi dominado principalmente pela parcela gerada pela descarga fluvial, seguida (com uma ordem de grandeza menor) pelas parcelas geradas pelo deslocamento da onda de maré (marés de sizígia) ou pela circulação gravitacional (marés de quadratura). As demais contribuições apresentaram valores máximos inferiores a duas ordens de grandeza em relação à parcela dominante.

Embora o nosso objetivo tivesse sido inicialmente o de investigar a eventual contribuição dos fluxos de águas subterrâneas para o sistema estuarino-lagunar de Cananéia-Iguape, a distribuição das concentrações dos isótopos naturais de Ra, especialmente ${ }^{228} \mathrm{Ra}$, evidenciaram que os níveis destes isótopos neste cenário representam os níveis naturais de ocorrência (níveis naturais de fundo ou "background"). Desta forma, a distribuição dos valores de atividade de ${ }^{226} \mathrm{Ra}$ e ${ }^{228} \mathrm{Ra}$ observados nas duas regiões aonde 
houve o levantamento de informações a respeito da qualidade dos recursos hídricos, quanto ao critério presença de minerais de $\mathrm{U}$ e Th e radioatividade natural, demonstra que as unidades não apresentam impacto de atividades antrópicas, podendo ser classificadas como zonas primitivas, cujos resultados denotam pequena ou mínima intervenção humana.

A distribuição das concentrações dos isótopos ${ }^{226} \mathrm{Ra}$ e ${ }^{228} \mathrm{Ra}$ em função da salinidade na barra de Cananéia foi dominada pela sua liberação das fases particuladas em salinidades maiores que 20, comprovando achados recentes do trabalho de Maluf (2009) para a distribuição de metais traço $\mathrm{Cu}, \mathrm{Zn} \mathrm{e} \mathrm{Pb}$, cujos trabalhos de campo foram conduzidos no mesmo período deste. Outros trabalhos de pesquisa realizados na última década no sistema de Cananéia/ Iguape demonstraram que o mesmo ocorre quanto à liberação de metais, nutrientes e balanço de sal (Braga, 2002; Bégamo, 2000). Os valores de salinidade determinados tanto nas amostras de água das estações hidroquímicas do Rio Ribeira de Iguape, quanto nas águas subterrâneas se apresentaram inferiores 1 durante todo o período de estudo. A baixa salinidade das águas dos poços amostrados indica que o processo de intrusão de água do mar no aqüífero costeiro é mínimo.

No caso das estações hidroquímicas coletadas no Rio Ribeira e nos estuários, em todos os casos em que se registrou aumento do material particulado em suspensão, também se obtiveram maiores concentrações de ${ }^{228} \mathrm{Ra}$ nas águas ensaiadas. Os resultados das razões isotópicas evidenciam uma predominância dos isótopos de ${ }^{228} \mathrm{Ra}$ da série natural do ${ }^{232} \mathrm{Th}$ em todas as amostras estudadas, em comparação com os isótopos de ${ }^{223} \mathrm{Ra},{ }^{224} \mathrm{Ra}$ e ${ }^{226} \mathrm{Ra}$, reflexo da presença de uma concentração maior de ${ }^{232} \mathrm{Th}$ em relação ao ${ }^{238} \mathrm{U}$ nas rochas e sólidos dos aqüífero na região de interesse.

A razão de atividade ${ }^{228} \mathrm{Ra} /{ }^{226} \mathrm{Ra}$ aumentada determinada na estação hidroquímica CAN1A, localizada próximo a Barra de Cananéia, é conseqüência da alta força-iônica neste local (salinidade 31,6). Na estação RIB2, os valores anômalos da razão de atividade ${ }^{228} \mathrm{Ra} /{ }^{226} \mathrm{Ra}$ é um indicativo de que neste local há uma grande troca destes isótopos com o sedimentos ou o material em suspensão. Nesta posição pode existir turbulência ou possível nascente, uma vez que o baixo valor de salinidade demonstra que a força-iônica não foi o processo dominante de liberação do Ra do material particulado em suspensão. 
As maiores razões de atividade ${ }^{228} \mathrm{Ra} /{ }^{226} \mathrm{Ra}$ nas águas subterrâneas foram obtidas em Ilha Comprida, em virtude da proximidade com a linha de costa.

Silicato e o nitrato foram os nutrientes que se apresentaram em concentrações mais significativas, sendo os valores observados de até $255,5 \mu \mathrm{mol} \mathrm{L} \mathrm{L}^{-1}$ e $782,4 \mu \mathrm{mol} \mathrm{L}{ }^{-1}$, respectivamente.

Nas amostras coletadas ao longo do Rio Ribeira de Iguape e nos estuários de Cananéia e de Iguape, as maiores concentrações dos isótopos de Ra foram observadas nas águas de fundo, indicando a difusão do ${ }^{228} \mathrm{Ra}$ dos sedimentos recentemente depositados como uma fonte potencial das concentrações aumentadas deste isótopo em relação aos demais. As concentrações dos isótopos de meias-vidas curtas foram negligenciáveis, em sua maior parte menores que o limite inferior de detecção do método.

Os fluxos de Ra para o sistema na Barra de Cananéia foram fortemente influenciados pelas correntes e canais de maré, que modulam o aumento ou diminuição das concentrações de Ra em resposta direta ao respectivo aumento e diminuição da salinidade das águas. No estuário de Iguape e nas estações hidroquímicas realizadas no Rio Ribeira do Iguape observou-se uma correlação linear entre a quantidade de material em suspensão (MES) e o aumento da concentração de ${ }^{228} \mathrm{Ra}$.

As concentrações de ${ }^{226}$ Ra não apresentaram distribuição idêntica aquelas do ${ }^{228} \mathrm{Ra}$. Isto demonstra um aporte negligenciável advectivo das águas intersticiais dos sedimentos e subterrâneas para o cenário de interesse, confirmando os resltados do trabalho de Bérgamo (2000). Os fluxos dominantes de elementos-traço, radionuclídeos e nutrientes tem suas maiores fontes centradas no compartimento fluvial, sedimentos e material em suspensão.

As concentrações de atividade de ${ }^{226} \mathrm{Ra}$ e ${ }^{228} \mathrm{Ra}$ determinadas nas águas subterrâneas e águas de superfície do Alto Vale do Ribeira e da Planície Costeira do Litoral Sul do Estado de São Paulo (2009 - 2010) são da mesma ordem de grandeza daquelas determinadas no Litoral Norte (Burnett et al., 2008; Moore \& Oliveira, 2008; Sousa, 2008). Estes resultados foram utilizados para se avaliar as doses efetivas comprometidas potencialmente recebidas pelos indivíduos do público que consomem as águas analisadas. A determinação deste parâmetro é inédita para a região e tem por 
finalidades avaliar o atendimento à Portaria 518 do Ministério da Saúde (2004) que estabelece os limites de qualidade da água destinada ao consumo humano no Brasil. Estes cálculos consideraram a hipótese de consumo diário de $2 \mathrm{~L}$ de água ao longo de um ano (Oliveira et al., 2001). Os resultados obtidos demonstram que as doses calculadas não excederam nível de referência de dose efetiva comprometida recomendado de $0,1 \mathrm{mSv}$, considerando-se o consumo de água potável por um ano (WHO, 2003). Portanto, quanto aos padrões de qualidade radioativa, as águas subterrâneas e de superfície do Vale do Ribeira e da Planície Costeira de Cananéia-Iguape podem ser consumidas sem que isto ocasione algum dano adicional à saúde da população. 


\section{REFERÊNCIAS BIBLIOGRÁFICAS}

ALLEGRINI, M.F. Avifauna como possível indicador biológico dos estádios de regeneração da Mata Atlântica. Dissertação de mestrado, Programa de pós-graduação em ciências Ambientais - USP, São Paulo, 1997.

AMINOT, A. \& CHAUSSEPIED, M. Manual des Analyses Chimiques en Milieu Marin. Brest: Centre National pour Exploitation des océans - CNEXO, 1983.

ANA - Agencia Nacional de Águas. Relatório de Gestão 2001. Brasília: $\boldsymbol{A N A}, 2002$. Disponível em www.ana.gov.br Acesso em : 23 Set. 2010.

BÉRGAMO, A.L. Caracterização da Hidrografia, circulação e transporte de sal: Barra de Cananéia, Sul do Mar de Cananéia e Baía do Trapandé. Dissertação de mestrado. Instituto Oceonográfico - USP, São Paulo, 2000.

BEU, S.E. Análise socioambiental do complexo estuarino-lagunar de Cananéia-Iguape e Ilha Comprida (SP): subsídio para o planejamento ambiental da região. Programa de Pós-Gradução em Ciências Ambientais - PROCAM. 2008. Dissertação de Mestrado Universidade de São Paulo. São Paulo.

BOKUNIEWICZ, H.;BUDDEMEIER, R.; MAXWELL, B.; SMITH, C. The typological approach to submarine groundwater dischager (SGD), Biogeochemistry. v.66, p. 145-158, 2003.

BOKUNIEWICZ, H.; TANIGUCHI, M.; ISHITOIBI, T.; CHARETTE, M.; ALLEN, M.; KONTAR, E.A. Direct measurements of submarine groundwater discharge (SGD) over a fractured rock aquifer in Flamengo Bay, Brazil. Estuarine, Coastal and Shelf Science, v. 76, p. 466-472, 2008.

BONOTTO, D.T.; CAPRIOGLIO, L. Radon in grounwaterfrom Guarany aquifer, South America: environmental and exploration implications. Applied Radiation and Isotopes, v. 57, p. 931-940, 2002.

BONOTTO, D.M. \& SILVEIRA, E.G. Geoquímica do Urânio. Aplicada a água mineral. Ed. UNESP, 2006.

BORGHetti, N.B.; BORGHETt, J. R.; ROSA FILHO, E. O Aqüífero Guarani. Disponível em: $<$ http://www.abas.org.br/educacao.php > . Acesso em: 05 Set. 2010.

BRAGA, E.S. Bioquímica Marinha. Efeitos da poluição nos processos bioquímicos. 2 ed. FUNDESPA, São Paulo, 2002

BROECKER, W.S.; LI, H.; CROMWELL, J. Radium-226 and Radon-222: concentration in Atlantic and Pacific oceans. Science, v. 158, p.1307, 1967.

BROECKER, W.S. \& PENG, T.H. Tracers in the Sea. Columbia University. Eldigio Pr. Lamont-doherty Geological observatory, Palisades - NY, p.690, 1982. 
BROUDRAUX, B.P.; HUETTEL, M.; FROSTER, S.; JAHNKE, R.A.; MCLACHLAN, A.; MIDDELBURG, J.J. Permeable marine sediments: overturning an old paradigm. EOS, v. 82: p. 133-136, 2001.

BUDDEMEIER, R. W. Groundwater Discharge in the Coastal Zone: proceedings of an International Symposium. LOICZ/R\&S/96-8, 179 pp. LOICZ, Texel, the Netherlands, 1996.

BURNETT, W.C. Offshore springs and seeps are focus of working group. EOS, v.80, p.13-15, 1999.

BURNETT, W.C.; BOKUNIEWICZ, H.; HUTTEL, M.; MOORE, W.S.; TANIGUCHI, M. Groundwater and pore water inputs to the coastal zone. Biogeochemistry, v.66, p. 3-33, 2003.

BURNETT, W.C.; DULAIOVA, H. Radon as a tracer of submarine groundwater discharge into a boat basin in Donnalucata, Sicily. Continental Shelf Research, v. 26, p. 862-873, 2006.

BURNETT, W.C.; AGGARWAL, P.K.; AURELI, A. BOKNIEWICZ, H.; CABLE, J.E.; CHARETTE, M.A.; KONTAR, E.; KRUPA, S.; KULKARNI, K.M.; LOVELESS, A.; MOORE W.S.; OBERDORFER, J.A.; OLIVEIIRA, J. OZYURT, N.; POVINEC, P.; PRIVITERA, A.M.G.; RAJAR, R.; RAMESSUR,R.T.; SHOLTEN, J.; TANIGUCHI, M.; TURNER, J.V. Quantifying submarine groundwater discharge in the coastal zone via multiple methods. Science of the total environment, v. 367, p. 498-543, 2006.

BURNETT, W.C.; PETERSON, R.; MOORE, W.S.; OLIVEIRA, J. Radon and radium isotopes as tracers of submarine groundwater discharge - Results from the Ubatuba, Brazil SGD assessment intercomparison. Estuarine, Coastal and Shelf Science, v. 76, p. 501$511,2008$.

CABLE, J.E.; BURNETT, W.C.; CHANTON, J.P.; WEATHERLY, G.L. Estimating groundwater discharge into a northeastern Gulf of Mexico using radon-222, Earth and Planetary Science Letters, v. 144, p.591-604, 1996.

CABLE, J.E.; BURNETT, W.C.; CHANTON, J.P., Magnitude and variations of groundwater seepage along a Florida marine shoreline, Biogeochemistry, v.38, p.189-205, 1997.

CABLE, J.E.; MARTIN, J.B. In situ evaluation of nearshore marine and fresh pore water transport into Flamengo Bay, Brazil. Estuarine, Coastal and Shelf Science, v.76, p.473483, 2008.

CAMPOS, M.L.A.M. Introdução à Biogeoquímica de Ambientes Aquáticos. Campinas, SP: Editora Átomo, p. 165-170, 2010 
CARVALHO, V.C.; RIZZO, H.G. A Zona costeira brasileira: Subsídios para uma avaliação ambiental. Ministério do Meio Ambiente e da Amazônia Legal BrasileiraMMA, 1994.

CETESB - Companhia de Tecnologia de Saneamento Ambiental. Realtório de águas interiores do Estado de São Paulo. CETESB, 2006.

CETESB - Companhia de Tecnologia de Saneamento Ambiental. Realtório de Qualidade das águas litorâneas no Estado de São Paulo Balneabilidade das praias. CETESB, 2007.

CONAMA - Conselho Nacional do Meio Ambiente. Resolução CONAMA nº 357, D.O.U. de 18.03.2005. s.1, p. 58-63, 2005.

CORBETT, D.R.; BURNETT, W.C.; CABLE, P.H.; CLARK, S.B. Radon tracing of groundwater input into Par Pond, Savannah River Site. Journal of Hydrology, v.203, p. 209-227, 1997.

CORBETT, D.R.; KUMP, L.; DILLON K.; BURNETT, W.C.; CHANTON, J. Fate of wastewater-borne nutrients under low discharge conditions in the subsurface of the Florida Keys, USA . Marine Chemistry, v. 69, p. 99-115, 2000.

COTHERN, C.R.; REBERS, P.A. In: Radon, radium and uranium in drinking water. Lewis Publishers Inc., Chelsea, Michigan, USA, 1991.

COWART, J.B.; BURNETT, W.C. The distribution of uranium and thorium decay-series radionuclides in the environment - A Review. Journal of Environmental Quality, v.23(4) July-August, p.651-662, 1994.

COWART, J.B.; OSMOND, J.K. Uranium isotopes in groundwater: their use in prospecting for sandstone-type uranium deposits, Journal of Geochemical Exploration, v.8, p.365-379, 1977.

CRH- RB - Comitê da Bacia Hidrográfica do Ribeira de Iguape e Litoral Sul. Relatório de situação dos recursos hídricos da UGRHI 11- Relatório Zero. Disponível em: http://geolig.igc.usp.br/geoproc/rs ugrhi rb/. Acesso em: 08 de Ago 2010.

DAMATTO, S.R. Radionuclideos naturais das séries do ${ }^{238} U \boldsymbol{e}^{232} \mathrm{Th}$, elementos traço $\boldsymbol{e}$ maiores determinados em perfis de sedimento da baixada santista para avalição de áreas impactadas. Tese de Doutorado. Instituto de Pesquisa Energéticas e Nucleares, São Paulo, 2010.

DAEE - DEPARTAMENTO DE ÁGUAS E ENERGIA ELÉTRICA. Controle de erosão: bases conceituais e técnicas, diretrizes para o planejamento urbano e regional, orientações para o controle de boçorocas urbanas. São Paulo: D.A.E.E., p. 92, 1989.

DICKSON, B.L.; DAVIDSON, M.R. Interpretation of U-234/U-238 activity ratios in groundwaters. Chem. Geol. (Isotope Geosc. Sect.), v. 58, p. 83-88, 1985.

DIEGUES, A.C. O Vale Ribeira e o Litoral de São Paulo: meio-ambiente, história e população. CENPEC, São Paulo, 2007. 
ELSINGER, R.J.; MOORE, W.S. Ra-226 behaviour in the Pee Dee River-Winyah Bay estuary. Earth and Planetary Science Letters, v. 48, p. 239-249, 1980.

ELSINGER, R.J.; MOORE, W.S. Ra-224, Ra-228 and Ra-226 sources in Winyah Bay and Delaware Bay. Earth and Planetary Science Letters, v. 64, p. 430-436, 1983.

EYSinK, G. G. J., PÁdUA, H. B., PIVA-BertoletTi, A. E., MARTinS, M. C., PEREIRA, D. N. Metais pesados no Vale do Ribeira e Iguape-Cananéia. Ambiente: Rev. CETESB de Tecnologia, São Paulo, Brasil, v. 2 (1), p. 6-13, 1988.

FREITAS, R.C. Evolução recentes das margens dos canais lagunares e topografia de fundo do sistema Cananéis-Iguape/SP. Dissertação de Mestrado, Instituto Oceonográfico da Universidade de São Paulo - IOUSP, São Paulo, 2005.

GEOBRÁS S.A. Complexo Valo Grande, Mar Pequeno e Rio Ribeira de Iguape, v.2, Geobrás, São Paulo, 1966.

GIATTI, L.L.; ROCHA, A.A.; SANTOS, F.A.; BITENCOURT, S.C.; PIERONI, S.R.M. Condições de saneamento básico em Iporanga, Estado de São Paulo. Revista de Saúde Pública, v.38(4), p. 571-577, 2004.

GARDOLINSKI, P.C.F.C.; DAVID, A.R.J.; WORSFOLD, P.J. Miniature flow injection analyzer for laboratory, shipboard and in situ monitoring nitrate in estuarine and coastal waters. Talanta, v. 58, p. 1015-1027, 2002.

GRASSHOFF, K.; EHRHARDT, M.; KREMLING, K. In: Methods of Seawater Analysis, $2^{\text {nd }}$ ed.Verlag Chemie, Weinhein, 1983.

HANSHAW, B.; BACK, W. Chemical mass-wasting of the northern Yucatan Peninsula by groundwater dissolution, Chemical Geology, v.8, p. 222-224, 1980.

HOLBY, O.; EVANS, S. The vertical distribution of Chernobyl - derived radionuclides in a Baltic Sea sediment. J.Environm.Radioactivity, v.33(2), p.129-145, 1996.

IAEA - Internacional Atomic Energy Agency. Nuclear and isotopic techniques for the characterization of submarine groundwater discharge in coastal zones. IAEA-TECDOC$1595,2008$.

INMET - Instituto nacional de Meteorologia. Disponível em : http://www.inmet.gov.br/ Acesso em 30/09/2010.

IPT - Instituto de Pesquisas Tecnológicas do Estado de São Paulo. Mapa geomorfológico do Estado de São Paulo. São Paulo, 1981.

IPT - Instituto de Pesquisas Tecnológicas do Estado de São Paulo. Potencial de biomassa vegetais para fins energéticos no Estado de São Paulo. São Paulo, v. 3, p, 868, 198.

ITESP - Fundação Instituto da Terra do Estado de São Paulo. Negro do Ribeira, reconhecimento ético e conquista do território. São Paulo, 2000. 
KATO, K. Geochemical studies on the mangrove region of Cananéia, Brazil. Tidal variations of water properties. Bol.Inst. Oceanogr., São Paulo, v. 15(1), p. 55-75, 1966.

KARMANN, I.; FERRARI, J. A. Carste e cavernas do Parque Estadual Turístico do Alto Ribeira (PETAR), SP. In:. SCHOBBENHAUS, C.; CAMPOS, D. A.; QUEIROZ, E. T.; BORN, M. Sítios geológicos e paleontológicos do Brasil. Brasília: DNPM-CPRMSIGEP, p. 401-413, 2002.

KARMANN, I. Evolução e dinâmica atual do sistema cárstico do alto Vale do Ribeira de Iguape, sudoeste do estado de São Paulo. 1994. 228 f. Tese de Doutorado. Instituto de Geociências, Universidade de São Paulo, São Paulo, 1994.

KAUFMANN, R.F.; BLISS, J.D. Effects of phosphate mineralization and phosphate industry on radium-226 in groundwater of central Florida. Rep. EPA/520-6-77-010. United States Environmental Protection Agency, Las Vegas, NV, 1977.

KAWAKUBO, F.S. Avaliação das mudanças nas linhas de costa na foz do Rio Ribeira de Iguape/desembocadura lagunar da barra de Icapara (litoral sul do Estado de São Paulo) utilizando dados do Landsat, MSS, TM e ETM. Investigaciones Geográficas Boletim del Instituto de Geografía UNAM, ISSN 0188-4611, v.68, p.41-49, 2009.

KNOPPERS, B.; SOUZA, W.F.L.; EKAU, W.; FIGUEREDO, A.G; GOMES, A.S. $\boldsymbol{A}$ interface terra-mar do Brasil. IN: CRESPO, R.P. \& SOARES-GOMES, A., Biologia Marinha, Ed. Interciências, Rio de Janeiro, Cap. 15, p. 529-553, 2009.

LAMPARELLI, C.C. Mapeamento dos ecossistemas costeiros do Estado de São Paulo. São Paulo, Secretaria do Meio Ambiente, Cetesb, p.108, 1999.

LEE, D.R. A device for measuring seepage flux in lakes and estuaries. Limnol. Oceanogr., v. 22, p. 140-147, 1977.

LEE, J.S. Radium Isotopes in the Ulsan Bay. Journal of Environmental Radioactivity, v.82, p. 129-141, 2005.

LEVY, D.M.; MOORE, W.S. Ra-224 in continental shelf water. Earth plant. Sci. Lett. v.73, p. 226-230, 1985.

LI, Y.H.; MATHIEU, G.; BISCAYE, P.; SIMPSON, H.J. The flux of ${ }^{226}$ Ra from estuarine and continental shelf sediments, Earth and Planetary Science Letters, v.37, p. 237-241, 1977.

LI, Y.H.; CHAN, L-H. Desorption of Ba and ${ }^{226} \mathrm{Ra}$ from river borne sediments in the Hudson Estuary, Earth Planet.Sci.Lett., v.43, p.343 - 350, 1979.

MALUF, J.C.C., Estudo dos matais traços (zinco, cádio e Chumbo) em duas regiões do Complexo Estuarino-Lagunar de Cananéia-Iguape (SP) sob diferentes pressões antrópicas. Dissertação de Mestrado. Instituto Oceanográfico - USP, São Paulo, 2009. 
MARINS, R.V.; BITTENCOURT, L.P.; MORETZ-SOHN, C. D.; CAVALCANTE, J. P. Glossário de Oceonografia Abiótica. Instituto de Ciências do Mar - LABOMAR. Fortaleza, 2010.

MARTIN, J.H.; GORDON, R.M.; FTZWATER, S.E. Iron in Antartic water. Nature, v. 345, p. 156-158, 1990.

MIYAO, S.Y.; HARARI, J. Estudos preliminares da maré e das ondas de maré na região de Cananéia (25 S-048 w). Bolm. Inst. Oceanogr., São Paulo, v. 37(2), p. 107-123, 1989.

MIYAO, S.Y.; NISHIHARA, L.; SARTI, C. Características físicas e químicas do sistema estuarino-lagunar de Cananéia-Iguape. Bol.Inst.Oceanogr., São Paulo, v.34, p. 23-36, 1986.

MOREL, F.M.M.; PRICE, N.M. The biogeochemical cycles of trace metals in the oceans. Science, v.300, p.944-947, 2003.

MOREL, F.M.M.; MILLIGAN, A.J.; SAITO, M.A. Marine bioinorganic chemistry the role of trace metals in the oceanic cycles of major nutrients. In: The oceans and marine geochemistry. Treatise on geochemistry. Ed. Elderfild, p. 113-143. Oxford, Elsevier, 2003.

MOORE, W.S. Oceanic concentrations of ${ }^{226}$ Ra. Earth and Planetary Science Letters, v. 2, p. 231-234, 1969.

MOORE, W.S. Radium isotopes in estuaries and coastal water. In: The Environmental Behaviour of Radium, Technical Report Series, n³10, chapter.1, v.1, pp. 419-485, IAEA, Vienna, 1990.

MOORE, W.S.; ARNOLD, R. Measurement of ${ }^{223}$ Ra and ${ }^{224} \mathrm{Ra}$ in coastal waters using a delayed coincidence counter. Journal of Geophysical Research, v.101, p. 1321$1329,1996$.

MOORE, W. S. High fluxes of radium and barium from the mouth of the GangesBrahmaputra River during low river discharge suggest a large groundwater source. Earth and Planetary Science Letters, v.150, p. 141-150, 1997.

MOORE, W.S.; SHAW, T.J. Chemical signals from submarine fluid advection onto the continental shelf, Gephys.Res., v.103, p. 21543-21552, 1998.

MOORE, W.S. The subterranean estuary: a reaction zone of ground water and sea water. Marine Chemistry, v.65, p. 111-125, 1999.

MOORE, W.S.; OLIVEIRA, J. Determination of residence time and mixing processes of Brazil, inner shelf waters using natural $\mathrm{Ra}$ isotopes. Estuarine, Coastal and Shelf Science, v.76, p.512-521, 2008.

MOORE, W.S. The Effect of Submarine Groundwater Discharge on the Ocean. Annu. Rev. Mar. Sci. v.2, p.59-88, 2010. 
MORAES, R.P. Transporte de chumbo e metais associados no rio Ribeira de Iguape, São Paulo, Brasil. Dissertação de Mestrado, Instituto de Geociências, Unicamp, Campinas, 1997.

NASCIMENTO Jr., D. R.; GINNINI, P.C.F.; TANAKA, A.P.B. Mudanças Morfológicas da Extremidade NE da Ilha Comprida (SP). OS Últimos dois séculos. Revista do Instituto de Geociências- USP. São Paulo, v.8(1), p. 25-39, 2008.

OBERDORFER, J.A.; CHARETTE, M.; ALLEN, M.; MARTIN, J.B.; CABLE, J.E. Hydrogeology and geochemistry of near - shore submarine groundwater discharge at Flamengo Bay, Ubatuba, Brazil. Estuarine, Coastal and Shelf Science. v.76, p.457-465, 2008.

OLIVEIRA, J. Determinação dos níveis de radioatividade natural em águas utilizadas para abastecimento público no Estado de São Paulo. Tese de Doutorado. Instituto de Pesquisas Energéticas e Nucleares, São Paulo,1998.

OLIVEIRA, J.; MAZZILLI, B.P.; SAMPA, M.H.O.; BABALAS, E. Natural radionuclides in drinking water supplies of São Paulo State, Brazil and consequent population doses. Journal of environmental radioactivity. V. 53, p. 99-109, 2001.

OLIVEIRA, J.; BURNETT, W.C.; MAZZILLI, B.P.; BRAGA, E.S.; FARIAS, L.A.; CHISTOFF, J.; FURTADO, V.V. Reconnaissance of submarine groundwater discharge at Ubatuba coast, Brasil, using ${ }^{222} \mathrm{Rn}$ as a natural tracer. Journal of Environmental Radioactivity, v.69, p. 37-52, 2003.

OLIVEIRA, J.; CHARETTE, M.; ALLEN, M.; BRAGA, E.S.; FURTADO, V.V. Coastal water Exchange rate studies at the southeastern Brazilian margin using $\mathrm{Ra}$ isotopes as tracers. Radioactivity in the environment, v.8, p. 345-359, 2006.

OLIVEIRA, J.; COSTA, P.; BRAGA, E.S. Seasonal variations of Rn and SGD fluxes to Ubatuba embayments, São Paulo. Journal of Radioanalytical and Nuclear Chemistry, v. 269 (3), p. 689-695, 2006.

OLIVEIRA, J.; BRAGA, E.S.; JESUS, S.C.; ABRAHÃO, F.F.; SANTOS, G.F.; CHIOZZINI, V. Assessement of natural radium isotopes and $\mathrm{RN}$ in water samoles from cananéis-Iguape estuarine complex, São Paulo. International Nuclear Atlantic Conference-INAC, Rio de Janeiro, Brazil, 2009.

PEREIRA, E.B.; HAMZA V.M.; FURTADO, V.V.; ADAMS, J.A.S. U, Th and K content, heat production the thermal conductivity of São Paulo, Brazil, continental shelf sediments: a reconnaissance work. Chemical Geology, v. 58, p. 217-226, 1986.

POVINEC, P.P.; OLIVEIRA, J.; BRAGA, E.S.; COMANDUCCI, J.-F.; GASTAUD, J.; GREONING, M.; LEVY-PALOMO, I.; MORGENSTERN, U.; TOP, Z. Isotopic, trace element and nutrient characterization of coastal waters from Ubatuba inner shelf area, south - eastern Brazil. Estuarine, Coastal and Shelf Science, v.76, p. 522-542, 2008.

RAMA; MOORE, W.S. Using the radium quartet for evaluating groundwater input and water exchange in salt marshes, Geochim.Cosmochim Acta, v.60, p. 4645-4652, 1996. 
RORIGUES, M.; FURTADO, V.V.; TESSLER, M.G.; MAHIQUES, M.M. Atlas sedimentológico. Plataforma continental do Estado de São Paulo. Grupo de oceonografia geológica. Instituto Oceonográfico - USP, 2003.

ROSS, J.R.S.; MOROZ, I.C. Mapa geomorfológico do Estado de São Paulo. São Paulo: Departamento de Geografia/ FFLCH/ USP - IPT. 1997.

RUTGERS VAN DER LOEFF, M.M.; MOORE, W.S. The analysis of natural radionuclides in seawater. CHAPTER 13. In: Methods of seawater analysis, $3^{\text {rd }}$ edition, Grasshoff, Ehrhardt and Kremling eds., Verlag Chemie, Weinheim, Germany,1999.

SAA - Sistema de Administração Ambiental, Plano Nacional das Águas. Disponível em: $<$ http://saa-ambiente.agrinov.wikispaces.net/ >Acessado em: 21 de Set 2010.

SAITO, R.T. Radionuclideos $\left({ }^{210} \mathrm{~Pb},{ }^{226} \mathrm{Ra},{ }^{210} \mathrm{Po}\right.$ e $\left.{ }^{137} \mathrm{Cs}\right)$ no sistema costeiro CananéiaIguape: Estudos Ambientais. Tese de Doutorado, Instituto de Pesquisas Energéticas e Nucleares, São Paulo, 2002.

SCOR - Scientific Committel on Oceanic Research. Geotraces - An International study of the marine biogeochemical cycles of trance elements and their isotopes. Science Plan. Report 1, p.79, Plymouth, UK, 2006.

SILVA, R.H.P. Geoquímica e Impacto Ambiental do Arsênio no Vale do Ribeira (SPPR). Dissertação de Mestrado, Instituto de Geociências, Unicamp, Campinas, 1997.

SMA/SÃO PAULO. Macrozoneamento do Litoral Norte - Plano de Gerenciamento Costeiro. São Paulo, Secretaria do Meio Ambiente. 1996. (Série Documentos).

SOMA/ CETESB. Poluição das águas no estuário e Baía de Santos. São Paulo, Secretaria de Obras e do Meio Ambiente, CETESB, v.1, 1978.

SOUSA, K.C.P.M. Estudo dos fluxos fluviais de isótopos naturais de rádio e bário dissolvido para as enseadas de Ubatuba, litoral norte do Estado de São Paulo. 2008. Dissertação de Mestrado. Instituto de Pesquisas Energéticas e Nucleares, São Paulo.

STIEGLITZ, T.; TANIGUCHI, M.; NEYLON, S. Spatial variability of submarine groundwater discharge, Ubatuba, Brazil. Estuarine, Coastal and Shelf Science, v.76, p.493-500, 2008.

STRICKLAND, J.D.H. \& PARSONS, T.R. A manual for sea water analysis. Bull. Fish. Rs. Bd. Cananda, p. 167, 1968.

TANIGUCHI, M.; STIEGLITZ, T.; ISHITOBI, T. Temporal variability of water qualiy of submarine graundwater dischager in Ubatuba, Brazil. Estuarine, Coastal and Shelf Science, v.76, p.484-492, 2008.

TEIXEIRA, W.E. Determinação das concentrações dos isótopos naturais de Ra em amostras costeiras do litoral norte do Estado de São Paulo. Dissertação de Mestrado. Instituto de Pesquisas Energéticas e Nucleares, São Paulo, 2004. 
TESSLER, M.G. \& MAHIQUES, M.M. Utilization of coastal geomorphic features as indicators of longshore transport: examples of the Southern Coastal region of the state of São Paulo, Brazil, Journal of Coastal Research, v.9(3), p. 823-830,1993.

TESSLER, G.M., SUGUIO, K.; ROBILOTTA, P.R. Teores de alguns elementos traço metálicos em sedimentos pelíticos da superfície de fundo da região Lagunar CananéiaIguape. Simpósio Sobre Ecossistemas da Costa Sul e Sudeste Brasileira, Cananéia, v.2, São Paulo, p. 255-263, 1987.

TESSLER, M.G. \& FURTADO, V.V. Dinâmica de sedimentação das feições de assoreamento da região lagunar de Cananéia-Iguape, Estado de São Paulo. Boletim do Instituto Oceanográfico da USP, São Paulo, Brasil, v.32(2), p.117-124, 1983.

TESSLER, M.G. Sedimentação atual na região lagunar de Cananéia- Iguape, Estado de São Paulo. Dissertação de Mestrado, IG-USP, v.2, p.170, 1982.

TORGERSEN, T.; TUREKIAN, K.K.; TUREKIAN, V.; TANAKA, N.; DEANGELO, E.; O'DONNEL, J. ${ }^{224} \mathrm{Ra}$ distribution in surface and deep water Long Island Sound: source and horizontal transport rates US coast. Continental Shelf Research, v. 16 (12), p.1545 - 1559, 1996.

TRAJANO, E.; GNASPINI, P. Cavernas - Fundação para a Conservação e a Produção Florestal do Estado de São Paulo, Intervales, p.189-200, 1994.

TRÉGUER , P. \& LÊ CORRE, P. A manuel d'analysis des nutritifs dans l'eau de mer. 2ème éd. Brest. Université de Bretagne Occidentale, p. 110, 1975.

UNEP/GESAMP. The State of the Marine Environment. UNEP/Nairobi, Quênia, 156p. 1990.

UNESCO - UNITED NATIONS EDUCATIONAL, SCIENTIFIC AND CULTURAL ORGANIZATION. Submarine groundwater discharge: Management implications, measurements and effects. IHP-VI, Series on Groundwater $n^{\circ}$ 5, IOC Manuals and Guides n.44.ISBN: 99-9220-006-2, 2004.

WEBSTER, I.T.; HANCOCK, T.G.; MURRAY, A.S. Use of radium isotopes to examine porewater exchange in estuary. Limnol.Oceanogr., v.39, p. 1917-1927, 1994.

WILLIAMS, A.R.; KIRCHMANN, R.J. Radium - a historical introduction. In: The Environmental Behaviour of Radium, Technical Report Series, n³10, chapter.1, v.1, pp. 310, IAEA, Vienna, 1990.

WINDOM, H.; SMITH, R.; NIENCHESKI, F.; ALEXANDER, C. Uranium in rivers and estuaries of globally diverse, smaller watersheds. Marine Chemistry, v. 68, p. 307-321, 2000 .

ZEKTSER, I.S. Groundwater discharge into the seas and oceans: state of the art. In: Buddemeier, R.W. (ed), Groundwater discharge in the coastal zone. LOICZ ICBP, LOICZ, Texel, Russian Academy of Science, Moscow, Netherlands, p. 122-123, 1996. 